

UNA CRÍTICA DESCOLONIAL DEL TRABAJO 
Universidad Nacional Autónoma de México

Dr. Enrique Graue Wiechers Rector

Dr. Leonardo Lomelí Vanegas Secretario General

Ing. Leopoldo Silva Gutiérrez

Secretario Administrativo

Dr. Domingo Alberto Vital Díaz

Coordinador de Humanidades

InSTItUTO DE InVESTigaciones Económicas

Dra. Verónica Villarespe Reyes

Directora

Dr. César Armando Salazar López

Secretario Académico

Aristeo Tovías García

Secretario Técnico

Marisol Simón Pinero

Jefa del Departamento de Ediciones 


\section{Una crítica descolonial del trabajo}

Boris Marañón-Pimentel
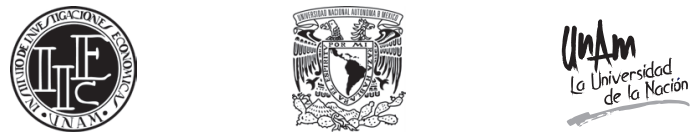

INSTITUTO DE INVESTIGACIONES ECONÓMICAS UNIVERSIDAD NACIONAL AUTÓNOMA DE MÉXICO 
Marañón-Pimentel, Boris, autor.

Una crítica descolonial del trabajo / Boris Marañón-

Pimentel. -- Primera edición. -- Ciudad de México :

Universidad Nacional Autónoma de México, Instituto

de Investigaciones Económicas, 2017.

256 páginas $; 21 \mathrm{~cm}$.

Bibliografía: páginas 241-255

ISBN 978-607-02-9838-7

1. Colonización -- Aspectos económicos. 2. Trabajo -Aspectos Sociales. 3. Trabajo -- Aspectos morales y éticos. 4. Eurocentrismo. I. Universidad Nacional Autónoma de México. Instituto de Investigaciones Económicas. II. Título.

Primera edición: noviembre de 2017

D. R. () Universidad Nacional Autónoma de México

Ciudad Universitaria, Coyoacán, 04510, Ciudad de México

Instituto de Investigaciones Económicas, UNAM

Circuito Mario de la Cueva s/n

Ciudad de la Investigación en Humanidades

04510, Ciudad de México

Proyecto PAPIT IN303216 "De la crisis estructural del empleo al trabajo recíproco en el México actual. Discursos y prácticas en organizaciones económicas solidarias"

\section{ISBN 978-607-02-9838-7}

Cuidado de edición y diseño de interiores: Marisol Simón Pinero Diseño de la portada: Juan Carlos Burgoa

Prohibida la reproducción total o parcial por cualquier medio sin la autorización escrita del titular de los derechos patrimoniales Impreso y hecho en México / Printed and made in Mexico 


\section{Índice}

$\begin{array}{ll}\text { Introducción } & 9\end{array}$

1. El lugar teórico de partida 23

1.1. La (des)colonialidad del poder 23

1.2. La modernidad instrumental y la idea eurocéntrica de la igualdad 31

1.3. Debate acerca del eurocentrismo en Marx 41

1.4. Razón histórica, civilización y progreso. El capitalismo como inevitabilidad y necesidad. La ruina de la razón histórica y el predominio de la razón instrumental

2. La colonialidad del trabajo en Occidente 59

2.1. Antes de la colonialidad-modernidad 59

2.1.1. Aristóteles en la Antigüedad griega: visión reduccionista del trabajo. Desprecio por el trabajo manual

2.1.2. San Agustín y santo Tomás de Aquino en el medioevo y el cristianismo: hacia una valoración positiva del trabajo manual y el reconocimiento del trabajo intelectual

2.1.3. Balance del concepto de trabajo antes de la colonialidad-modernidad

2.2. En la colonialidad-modernidad: el trabajo asalariado productivo, abstracto y homogéneo, creador de riqueza y la invisibilización de las otras formas de control del trabajo 
2.2.1. Lutero y Calvino: la revalorización 101

2.2.2. Locke, Genovesi y Smith: hacia la legitimidad e instrumentalidad

2.2.3. Marx: crítica radical al capitalismo y tensiones eurocéntricas

2.2.4. Balance de la revisión del concepto colonial-moderno de trabajo: la colonialidad de todas las formas históricas de trabajo 216

3. Reflexiones finales: hacia la descolonialidad del trabajo y el Buen vivir

Bibliografía 


\section{Introducción}

El aporte de esta investigación, desde el sentipensamiento descolonial, es tratar de entender, primero, las concepciones que se han tenido del trabajo a lo largo de la historia occidental, y después, tanto los lugares y papeles asignados a la gente en este ámbito de la existencia social, como las razones que explican tal distribución en las relaciones de poder. Nos interesa discutir cómo, por un lado, el trabajo (work), actividad creativa y autónoma, manual e intelectual, destinada a proveer las necesidades básicas, a enriquecer la vida humana y efectuada dentro de una cotidianidad que enlazaba todos los aspectos de la vida, fue convertido por el patrón de poder moderno-colonial, global, capitalista y eurocentrado, en empleo (job), asalariado, manual, abstracto y homogéneo, subordinado y subordinando la vida misma al trabajo asalariado. Esto es, nuestro objetivo se orienta a tratar de explicar de qué modo trabajar para vivir fue sustituido por vivir para trabajar en la modernidad colonial eurocentrada, lo cual requirió una redefinición radical del concepto de producción, mismo que fue separándose de su contexto natural y material, como apunta Naredo [1987]. Siendo el eje de análisis la colonialidad del trabajo, este concepto está referido al trabajo asalariado; sin embargo, los otros tipos de trabajo (servil, esclavo, pequeña producción mercantil simple, reciprocidad) que provienen del mundo premoderno-colonial también se incorporan a la colonialidad-modernidad. Lo que ocurre es que el trabajo asalariado corresponde al capital, mientras que todas las otras formas de trabajo son parte del capitalismo, con lo 
que la colonialidad del trabajo no se refiere sólo al trabajo asalariado, sino al trabajo en el sistema dentro del cual se desarrolla el trabajo ${ }^{1}$. Existen, por lo tanto, diferentes formas de control del trabajo, todas ellas afectadas por la noción de raza, según los desarrollos teóricos de Wallerstein y Quijano.

Al mismo tiempo, la presente investigación trata de mostrar cuáles son las nuevas concepciones de trabajo que emergen con los recientes movimientos sociales, especialmente indígenas, que no sólo cuestionan la colonialidad del trabajo, sino el patrón de poder moderno-colonial y capitalista en su conjunto, es decir, la colonialidad del poder. Para tratar de dar cuenta de estas nuevas propuestas que pueden ser asociadas al Buen vivir, es imprescindible distanciarse de las narrativas eurocéntricas del trabajo y de la modernidad instrumental predominantes.

Considerando lo anterior, tendríamos que alejarnos de la idea de que trabajo es igual a trabajo asalariado, y destacar que, por el contrario, el trabajo asalariado es sólo una forma particular de la amplia gama de lo que llamamos trabajo, y poner en el centro de la discusión la necesidad de expandir el trabajo solidario y recíproco en nuestras sociedades.

Esta discusión requiere una lucha teórica y política. Una lucha por un imaginario distinto del progreso-desa-

${ }^{1} \mathrm{Al}$ respecto, Quijano [2014: 272] sostiene que "todas las formas que conocemos hoy de control y de explotación del trabajo, a partir de América, fueron reorganizadas todas, ya no como una secuencia de previos modos de producción, sino como formas de organización de explotación y de control del trabajo para producir mercancías para el mercado mundial. Es decir, no solamente existían simultáneamente, en el mismo momento y en el mismo espacio histórico, sino que fueron articuladas en torno del mercado y, por eso, en torno también de la relación capital-salario que desde entonces pasó a ser el eje central de esa articulación y de esa manera se hizo dominante sobre todas las demás relaciones de producción y sobre todo el mundo". A esta articulación de diversas formas históricas de control del trabajo, vista desde una perspectiva mundial y no evolucionista, Quijano la denomina capitalismo. 
rrollo, lo que requeriría asociar la propuesta del trabajo solidario y recíproco a otra propuesta de sociedad, como el Buen vivir. Esto supone reconocer que la subjetividad (conocimiento, memoria histórica, imaginario) es un elemento constitutivo de las relaciones de poder en una sociedad, pues en la subjetividad dominante se ha naturalizado y legitimado un tipo de trabajo, el asalariado, caracterizado por ser vertical, enajenado, vinculado a las relaciones mercantiles y a la acumulación capitalista, y asociado al imaginario del progreso-desarrollo, al crecimiento económico sin fin y a la explotación de la naturaleza. Por estas razones, es necesario erradicar las ideas y prácticas de dominación y explotación. Asimismo, resignificar los conceptos y articular la lucha por la solidaridad económica (reciprocidad y desmercantilización del trabajo, la vida y la naturaleza, con un imaginario en el cual no se considere a la naturaleza y a la vida humana como desechables, en el que haya igualdad social (descreyendo las ideas de raza y diferencias sociales entre sexos, y erradicando la dominación y explotación en el trabajo).

Somos parte, desde hace dos décadas, de la emergencia de un nuevo horizonte de sentido histórico que cuestiona de manera radical la mercantilización y la búsqueda de la ganancia como ejes de la existencia social, ambas, características básicas del capitalismo, en tanto estructura de explotación social. Este nuevo horizonte de sentido que ha surgido a partir de un movimiento mundial de resistencia a las tendencias depredadoras y destructivas del capitalismo, dominado por la fracción financiera del capital, tiene como actor central a los indígenas, y como eje fundamental la defensa de la Madre Tierra, junto con el impulso de procesos de desmercantilización de la misma, de la vida y del trabajo.

Este amplio movimiento mundial en defensa de la Casa común, la Tierra [Quijano, 2009], implica una crítica profunda al sentido dominante de la vida en el capitalismo 
moderno-colonial y a la manera en que éste, por medio del eurocentrismo, ha producido e impuesto una intersubjetividad basada en la racionalidad instrumental que nos hace perseguir, vanamente, una forma de vida - la euroestadounidense- que no corresponde al sentido histórico de nuestras sociedades ${ }^{2}$. Una forma de vida fundada en relaciones sociales sujeto-objeto, racializadas y jerarquizadas; en una visión dualista-evolucionista que nos dice el progreso y el desarrollo, y sus instituciones asociadas (Estado, trabajo asalariado, naturaleza cosificada, mercancía, patriarcado, entre otras), son imágenes-verdades ya cristalizadas, ya logradas en la vida cotidiana de las sociedades euroestadounidenses y que debemos alcanzarlas como la única manera legítima para vivir en mejores condiciones, aunque la experiencia histórica muestre lo contrario.

El eurocentrismo, en tanto estructura de saber que ha buscado garantizar el mantenimiento del patrón de poder colonial-moderno, ha naturalizado todo este conjunto de instituciones y sentidos de la vida. Un aspecto crucial de la colonialidad-modernidad es la naturalización del significado del trabajo como trabajo asalariado (empleo) y objeto. De este modo, el trabajo asalariado se convirtió en el único trabajo legítimo, en el único productor de riqueza, en el eje de estructuración e identidad sociales. Las otras formas de trabajo no asalariado, llámense trabajo doméstico, trabajo campesino o trabajo basado en la reciprocidad, entre otros, no tienen ningún reconocimiento social y son concebidos como formas "atípicas" y atrasadas en la concepción dualista-evolucionista que caracteriza al eurocentrismo. Al mismo tiempo, la Madre Tierra, concebida en la Antigüedad occidental como un organismo vivo, sagrado y animado, aunque se basara en

2 Es importante señalar que el eurocentrismo también se impuso en las sociedades europeas. 
una visión antropocéntrica, ha devenido, en la modernidad-colonialidad, en un objeto que debe ser dominado y explotado, en un recurso que debe servir como mercancía y para la acumulación de capital, sin contemplar sus condiciones de existencia y reproducción, y su lugar central como posibilitador de la vida humana.

En términos subjetivos, la identificación del trabajo asalariado como trabajo, está muy difundida en el mundo académico, incluyendo a quienes desde distintas avenidas tienen una postura crítica respecto al modo de vida vigente y al deterioro de la calidad del trabajo asalariado; nos referimos a Meda [1996 y 1998], Rifkin [1996], Neffa [2001] y De la Garza [2001 y 2010], entre otros, quienes han brindado invalorables aportes al cuestionar el capitalismo y la opresión de los trabajadores. Naredo es claro en afirmar que:

la noción actual de trabajo no es una categoría antropológica ni menos aún, un invariante de la naturaleza humana. Se trata, por el contrario, de una categoría profundamente histórica. El trabajo, como categoría homogénea, se afianzó allá por el siglo xviII junto con la noción unificada de riqueza, de producción y la propia idea de sistema económico para dar lugar a una disciplina nueva: la economía. La razón productivista del trabajo surgió y evolucionó, así, junto con el aparato conceptual de la ciencia económica [Naredo, 1997: 37].

Por su parte, Meda afirma que en las sociedades no capitalistas el trabajo es una actividad asociada a la supervivencia, no hay en ellas una distinción como en la sociedad industrial entre el tiempo de trabajo y tiempo libre, por ello: "El trabajo en las sociedades preeconómicas presenta tres características: primero, se acomete para ser visto por los demás, es una suerte de competición lúdica, de juego social (...) segundo, ni la satisfacción de 
las necesidades, ni el ánimo de acopio son primordiales (...) por último, el trabajo se rige por lógicas sagradas y sociales" [Meda: 1998: 31].

Applebaum [1992 y 1987] plantea que el trabajo (asalariado), es una poderosa imagen que no existía en la Antigüedad ni en la Edad Media. Lo mismo es sostenido por Anthony [2001] y Tilgher [1930]. Anthony sostiene el gran contraste entre el desprecio al trabajo en ambos periodos (la Antigüedad y la Edad Media) en contraste con lo que sucede a partir de la colonialidad-modernidad:

El mayor contraste con nuestras propias actitudes respecto del trabajo se remonta a las raíces clásicas de nuestra sociedad. Sabemos que una gran parte de nuestro equipamiento intelectual, la fábrica básica de nuestra cultura, proviene de la Grecia clásica. Pero las ideas atenienses sobre el trabajo no solo son remotas en el tiempo sino son contrarias en valores a los nuestros. El trabajo no fue tomado seriamente en la Grecia clásica, no tenía asignado el valor moral que ha ganado en los veinte siglos de cristianismo y desde el nacimiento del movimiento obrero. Mosse [1969:25] cita a Xenofonte como el temprano ejemplo de desprecio sobre el trabajo: Sin duda, las artes no liberales son consideradas con desdén en nuestros estados. Dichas artes arruinan los cuerpos de los trabajadores y capataces, forzándolos a sentarse y vivir en interiores, y en algunos casos pasan el día frente al fuego. El ablandamiento del cuerpo implica un serio debilitamiento de la mente [Anthony, 2001:15].

No obstante, Anthony y numerosos investigadores, por su perspectiva eurocéntrica, no han advertido la línea de continuidad epistemológica y ontológica entre el pensamiento griego y el colonial-moderno actual respecto de la desigualdad natural-servidumbre natural y la "raza" como criterios que han definido históricamente la distribución de las personas en el control del trabajo, en las 
relaciones de poder, y de modo más general en las relaciones de mando y obediencia en los periodos históricos que denominamos antes de la modernidad-colonialidad y la modernidad-colonialidad.

La naturalización eurocéntrica del trabajo asalariado encuentra sus límites en la fase financiera del capitalismo moderno-colonial al evidenciarse el agotamiento de la generación de trabajo asalariado regulado y multiplicarse las magnitudes de trabajadores desempleados (desempleo estructural) y subempleados, así como la pérdida creciente de calidad de los empleos y la reemergencia de otras formas de control del trabajo, entre ellas la esclavitud, por un lado, y la reciprocidad, por el otro. Así, desde los años noventa del siglo pasado se habla de la crisis del trabajo, en alusión a la crisis del trabajo asalariado, no sólo en términos de generación de riqueza, sino como eje de estructuración social, identidad social y autoestima personal, y la única senda legítima para lograr la reproducción social.

Una de las nuevas propuestas es la que surge desde el movimiento mundial de resistencia al capitalismo, el mismo que está proponiendo desde la práctica social otro horizonte de sentido histórico, denominado Buen vivir [Quijano, 2009]. Esto significa, en el ámbito de nuestro estudio, maneras distintas de concebir el trabajo y la naturaleza. El trabajo orientado a la producción de valores de uso y desde la reciprocidad, y la naturaleza concebida como un sujeto que tiene sus propias leyes de reproducción y conservación, y como la Casa común de la humanidad, como la Madre Tierra. En ambos casos se plantea un proceso de desmercantilización.

En este contexto, el objetivo del presente texto es hacer una revisión respecto de cómo históricamente se creó la visión dominante del trabajo, y al mismo tiempo, hacer una aproximación a cómo desde las prácticas de los movimientos sociales contemporáneos se trata de re- 
significar este concepto. Este viaje intelectual se llevará a cabo desde el giro descolonial, esto es, desde la teoría de la colonialidad del poder, la que propone una nueva mirada, comprehensiva, de la historia de nuestras sociedades, planteando una reinterpretación de la vida social que signifique una ruptura con el eurocentrismo. Desde esta perspectiva, es necesario producir conocimiento y subjetividad alejándose de la mirada tejida e impuesta por las relaciones de poder en la modernidad-colonialidad. Así, como sostiene Mignolo, el giro descolonial es la:

apertura y la libertad del pensamiento y de formas de vida-otras (economías-otras, teoría políticas-otras); la limpieza de la colonialidad del ser y del saber; el desprendimiento de la retórica de la modernidad y de su imaginario imperial articulado a la retórica de la democracia. El pensamiento descolonial tiene como razón de ser y objetivo la descolonialidad del poder (es decir, de la matriz colonial de poder) [Mignolo, 2007: 29-30].

De este modo, la presente investigación, desde el pensamiento descolonial y abrevando de la teoría de la colonialidad del poder, busca conocer cómo ocurrió la producción social de corte eurocéntrico de la categoría trabajo (trabajo abstracto y homogéneo), y al mismo tiempo, la forma en que desde los movimientos sociales se va registrando una producción social y descolonial del trabajo, alejada del eurocentrismo.

Provistos ya de algunos conceptos centrales, entre ellos: colonialidad del poder, poder, eurocentrismo, capitalismo, heterogeneidad histórico-estructural, raza y clasificación social, emprenderemos un viaje, esperemos que no muy no azaroso, en el tiempo de las ideas y formas de organización de la sociedad, con la esperanza de llegar a buen puerto, a tratar de no habitar y ser habitados más por ciertas imágenes y prácticas eurocéntricas que difi- 
cultan y desorientan nuestras búsquedas emancipadoras y liberadoras.

Esta investigación, por su amplitud temporal, está centrada en identificar a algunos de los representantes más conspicuos del pensamiento social acerca del trabajo a lo largo de la historia de Occidente, sobre todo a aquellos que contribuyeron a establecer qué es el trabajo y cómo el control sobre éste se asigna entre la población como parte de la distribución de las relaciones de poder en una sociedad. Por tal razón, este estudio no trata de la reconstrucción de lo que era el trabajo en cada una de las etapas en las que convencionalmente se ha dividido la historia de Occidente (pretendiendo, equivocadamente, que se trata de la historia universal, de la historia de la humanidad).

La investigación se centra en identificar a algunos pensadores que hicieron contribuciones relevantes respecto del trabajo en diversas etapas históricas para tratar de explicar desde nuestro tiempo, cómo y por qué el trabajo se instaló de manera dominante en la subjetividad de nuestras sociedades como trabajo homogéneo y abstracto, como trabajo asalariado y productor de valores de cambio, como la única fuente legítima de obtener ingresos para los sectores sociales dominados y explotados, como el referente de la autoestima personal, de la integración social, de la emancipación. De este modo, se resaltan los aportes de Aristóteles, san Agustín, santo Tomás de Aquino, Lutero, Calvino, Locke, Genovesi, Smith y la crítica radical de Marx.

Resalta el giro registrado desde Aristóteles, para quien el trabajo era sólo manual, efectuado por esclavos y socialmente despreciado, a la visión actualmente dominante centrada en una valoración social positiva del trabajo manual y asalariado. Una visión en torno a la capacidad del trabajo asalariado que no se condice con la realidad de desempleo estructural creciente y de pérdida de derechos 
laborales en la etapa actual, dominada por la fracción financiera del capital.

Desde una mirada basada en la (des) colonialidad del poder, no existe una única historia universal que provenga de una experiencia particular, la europea. Ésta se impuso a todo el mundo por medio de relaciones de poder y significación, y de la legitimación del eurocentrismo como la única forma válida de producir conocimiento. Una mirada parroquial, según expresión de Dussel [2000], que se impuso a todo el mundo, a partir de la configuración del actual patrón de poder colonial, moderno, capitalista y eurocentrado, en el siglo xvI. Esta mirada parroquial, fue imponiéndose respecto de cómo entender el trabajo, desde la exterioridad, desde la negación del otro. Desde una mirada Occidental que pretende tener una línea de continuidad desde Grecia, cuando en realidad Occidente como tal es una creación de la colonialidad-modernidad desde el siglo XVI.

Por tanto, existen historias de personas que no tienen historia, desde la visión occidental, y de acuerdo con Wolf [2014], que no viven según esta narrativa dominada por una racionalidad social que exterioriza a las personas y a la Madre Tierra, basada en el individualismo, la racialización y la búsqueda de la acumulación de riqueza y poder. En estas otras historias, las poblaciones han vivido y siguen viviendo - a pesar de la violencia ejercida sobre su territorio, su cultura, su forma de vida- en este mundo colonial-moderno, a partir del autogobierno, de la reciprocidad y del respeto a la naturaleza, sin dejar de reconocer las fuertes contradicciones existentes dentro de ellas.

El texto está estructurado temporalmente en dos periodos denominados antes de la colonialidad-modernidad (hasta el siglo xv) y la colonialidad-modernidad (del siglo XVI a la actualidad). En el primero se revisan las ideas de Aristóteles, san Agustín y santo Tomás de Aquino respecto 
del trabajo. En el segundo, se discuten las ideas de Lutero, Calvino, Locke, Genovesi, Smith y Marx. Luego se presenta un apartado que trata de establecer algunos elementos para una definición descolonial del trabajo. En este sentido, al final del texto se abre una discusión preliminar respecto de la descolonialidad del trabajo, recogiendo para ello propuestas teóricas y prácticas orientadas hacia un nuevo sistema histórico y con otro horizonte histórico de sentido: el Buen vivir, que critica al desarrollo y al capitalismo, practicando nuevas formas de vida desde el control territorial, en tensión con el Estado y el mercado, a partir de racionalidades liberadoras y solidarias. En este esfuerzo, se trata de conjugar miradas que se encuentran dentro y más allá de la modernidad. En términos teóricos, como se ha manifestado, la investigación se basa en la teoría de la colonialidad del poder, propuesta por Aníbal Quijano.

El análisis de estas perspectivas intelectuales e históricas en torno al trabajo se ha efectuado mediante la consulta de fuentes secundarias, sobre todo, libros impresos que en su mayoría han sido conseguidos gracias a la diligente, cálida y solidaria colaboración de las compañeras de la biblioteca del IIEc-unam: Mariela Meza, Susana Gutiérrez y Víctor Medina. En la reproducción electrónica de varios textos históricos, Leticia León, Ana Maldonado y Beatriz Aurora han brindado su cuidadoso y generoso esfuerzo. Otras publicaciones, libros y artículos, en cambio, han sido obtenidos en internet, entre ellos, las obras de Aristóteles, san Agustín, santo Tomás de Aquino, Lutero, Calvino, Genovesi, Locke, Rousseau, Smith y Marx; aunque de este último se ha preferido consultar sus textos en la edición de Siglo XXI. Applebaum [1992], Jaccard [1977] y Diez [2001] son algunos de los autores cuyos estudios han servido para recorrer este largo camino. 
Expreso mi agradecimiento a Octavio Serrano, Ana Gutiérrez, Isabel Alejandre, Isabel Flores, Guillermina Martínez, Gregorio, Manuel Fernández, Nallely Natarén, Nancy Huidobro, Patricia Siguenza y Alejandro Palma, estudiantes de licenciatura de la UNAM, quienes elaboraron minuciosas fichas de diversos autores como parte de su servicio social. Bárbara Estrada hizo valiosos comentarios al borrador final del libro y Rosi Castillo y Liliana Sánchez, hicieron la revisión editorial.

Un reconocimiento a César Germaná y Walter Mignolo, al primero por hacer comentarios a un borrador de este escrito y al otro por participar conmigo sus reflexiones acerca de el "vivir para trabajar" y "trabajar para vivir", resaltando el bello fresco que Guamán Poma hizo en $E l$ primer nueva corónica y buen gobierno, hace no mucho tiempo, en el siglo xvi, en torno al "trabajo de los días". Igualmente, expreso mi agradecimiento a Danilo Clímaco de Assis y a Pablo Quintero, por la lectura atenta del borrador y sus agudas sugerencias. Mi deuda profunda con Manuel Valladares por haber tratado desde mi juventud de contagiarme su pasión por la historia y la búsqueda de la justicia social. Mi reconocimiento a Aníbal Quijano, por su ejemplar y límpida trayectoria en la lucha teórica y política por la transformación de esta sociedad.

$$
\text { *** }
$$

Esta investigación del concepto de trabajo en diversos tiempos históricos ha sido un largo viaje, asaz enriquecedor y esclarecedor. Al decir de Kavafis, el viajero ahora está más cercano a Itaca, tiene algo más de sabiduría y quizás puede entender un poco mejor la vida y la historia. Tal vez su sensibilidad sea más fina y pueda quizás escuchar con menor esfuerzo "el temblor de una hoja". Contará todo este aprendizaje al pequeñísimo Rodrigo, al ya caminante Ulises, a Sergio y Diego para que puedan crecer 
y sostenerse con un sentimiento firme y cálido anclado en la alegría de la solidaridad.

Finalmente, a ti, compañera de vida, y a Lidia, madre y maestra vida. 



\section{El lugar teórico de partida}

\subsection{LA (DES)COLONIALIDAD DEL PODER}

La presente investigación trata de inscribirse en el pensamiento descolonial, el mismo que históricamente tiene sus raíces en el tiempo en que se estaba fundando la modernidad-colonialidad, y que surge a partir del pensamiento indígena y el afrocaribeño, con las contribuciones de Guaman Poma de Ayala y de Ottobah Cougano. Ambos abrieron las puertas al pensamiento otro, con base en la experiencia y memoria de las prácticas de los ayllus del Tawantinsuyo y de la experiencia y memoria de la esclavitud negra del Atlántico, respectivamente [Mignolo, 2007]. Sería Mariátegui, siglos después, otro preclaro exponente de este pensamiento, pues en la segunda década del siglo pasado el revolucionario peruano logró elaborar una nueva manera de ver la realidad. Esta perspectiva de conocimiento partía de una óptica diferente de la que representaba la racionalidad en su versión instrumental de la modernidad europea, e implicaba una forma distinta de comprender la realidad social, los conflictos sociales y el sentido de la historia [Quijano, 1990]. De este modo, Mariátegui planteó como alternativa al capitalismo dominante en el Perú, el socialismo indoamericano, a partir de la historia y características de la sociedad peruana, pero dentro y en relación con el capitalismo global, destacando la vigencia en la población indígena - entonces mayoritaria cuantitativamente- de un espíritu colectivo que se remontaba a la etapa prehispánica [Germaná, 1995]. 
En esta orientación mariateguiana, en la actualidad, desde el lado del trabajo emergen propuestas que tienden a constituir una nueva racionalidad: liberadora y solidaria. Por un lado, está la vertiente histórica de la razón moderna, con sus ideas de libertad individual e igualdad social, del futuro como algo por conquistar y de la autoproducción democrática de la sociedad, y por otro, la vertiente india prehispánica [Germaná, 1995], con la reciprocidad, la solidaridad social y el trabajo colectivo. Surge así un proyecto utópico en el que se trata de articular dos herencias culturales: la racionalidad de origen andino ligada a la reciprocidad y solidaridad, con la primigenia racionalidad moderna, cuando la razón estaba asociada a la igualdad social, a la libertad individual y a la democracia como decisión colectiva. Se trata de una racionalidad alternativa a la razón instrumental e incluso a la propia razón histórica, es una utopía de asociación entre razón y liberación [Quijano, 1998], entendida la utopía no como algo irrealizable, sino como una forma de expresión de la subjetividad que "incorpora la dimensión del futuro como la potencialidad del presente" [Zemelman y Valencia, 1990: 94]. De esta manera, la utopía se articula en el presente, el pasado y el futuro, proyectando un porvenir que se construye con la fuerza de la experiencia y la capacidad imaginativa y creadora de los sujetos, se trata de un horizonte de sentido histórico [Quijano, 2009].

La presente investigación parte del pensamiento descolonial y trata de indagar la forma y razones por las cuales se puso en relieve con una luz fulgurante en el tiempo y en el espacio del mundo colonial-moderno capitalista, la idea del empleo como el universal del trabajo, mientras se dejaban en la sombra las otras formas de control del trabajo (esclavitud, servidumbre, reciprocidad y producción mercantil simple). Así pues, con el fin de entender la colonialidad del trabajo, es útil tener a la mano las nociones de heterogeneidad histórico-estructural y clasifica- 
ción social elaboradas por Quijano como elementos de su propuesta sobre la colonialidad del poder. Para entender estos conceptos es necesario explicar cómo se conciben tanto el poder como el patrón de poder colonial-moderno y capitalista, así como la clasificación social, en la perspectiva del autor.

EL PODER, PATRÓN DE PODER, CLASIFICACIÓN SOCIAL

El poder es definido "como un espacio y una malla de relaciones sociales de explotación/dominación/conflicto articuladas, básicamente, en función y en torno de la disputa por el control de los siguientes ámbitos de existencia social: (1) el trabajo y sus productos; (2) en dependencia del anterior, la "naturaleza" y sus recursos de producción; (3) el sexo, sus productos y la reproducción de la especie; (4) la subjetividad y sus productos materiales e intersubjetivos, incluido el conocimiento; (5) la autoridad y sus instrumentos, de coerción en particular, para asegurar la reproducción de ese patrón de relaciones sociales y regular sus cambios" [Quijano, 2007a].

En tanto que patrón de poder está conformado por tres elementos, una manera de producir conocimiento (el eurocentrismo), una estructura de dominación social (la colonialidad) y una estructura de explotación social (el capitalismo).

El eurocentrismo es una forma de dar sentido a la realidad social según una perspectiva específica surgida en Europa, con pretensiones de universalidad, impuesta a las propias sociedades europeas que orientaban sus acciones por racionalidades no instrumentales, que se erige como la única forma válida de conocimiento. Asimismo, sirve para legitimar el poder del capital y sus aliados, y naturalizar los procesos sociales, presentándolos como inamovibles e inmodificables. De acuerdo con esta narrativa, la vida 
social no es posible sin las instituciones básicas del capitalismo - familia patriarcal, Estado-nación y empresa, entre otras - y sostiene que el bienestar común se alcanza siguiendo las ideas de evolución, progreso, desarrollo, libre empresa privada, egoísmo y democracia representativa.

Quijano [2007a] sostiene que el eurocentrismo es la forma específica que asume el saber que se desarrolla en Europa a partir del siglo XVII y se impone como la perspectiva hegemónica de conocimiento en el patrón de poder moderno-colonial, capitalista y eurocentrado. Lander [2000], añade que los saberes modernos tienen dos dimensiones constitutivas, de orígenes históricos diferentes que contribuyen a explicar su eficacia y potencia naturalizadora a partir de su estrecha imbricación. La primera dimensión se refiere a las sucesivas separaciones o particiones del mundo de lo real, que se dan históricamente en la sociedad occidental y las formas como se va construyendo el conocimiento sobre las bases de este proceso de sucesivas separaciones. La segunda dimensión es la forma como se articulan los saberes modernos con la organización del poder, especialmente las relaciones coloniales-imperiales de poder constitutivas del mundo moderno. Estas dos dimensiones sirven de sustento sólido a la creación de ciencias sociales naturalizadoras de las relaciones de poder [Lander, 2000: 2]. Las posturas coloniales eurocéntricas del conocimiento moderno hegemónico se basan en la escisión entre objeto y sujeto, y en la creación de la razón como sujeto abstracto del conocimiento objetivo y universal. El sujeto es una categoría referida al individuo aislado, porque se constituye en sí y ante sí mismo, en su discurso y en su capacidad de reflexión; por su parte, el objeto es una categoría referida a una entidad no solamente diferente al sujeto-individuo, sino externo; asimismo, el objeto es también idéntico a sí mismo, pues está constituido por propiedades que le otorgan esa identidad, lo definen, esto es, lo deslindan y al mismo tiempo lo 
ubican respecto de otros objetos [Quijano, 1990: 14]. Así, lo que está en cuestión es, primero, el carácter individual e individualista del sujeto, pues se niegan la intersubjetividad y la totalidad social como sedes de la producción de todo conocimiento; segundo, la idea de objeto no considera que las propiedades son modos y momentos de un campo de relaciones; tercero, no existe tal exterioridad entre sujeto y objeto, pues hay una estructura de comunicación entre ellos [Quijano, 1990: 16].

Asimismo, se trata de un dispositivo epistemológico mediante el cual se oculta al sujeto del conocimiento dominante del mundo colonial-moderno: un sujeto europeo, blanco, masculino, de clase alta y, por lo menos en su presentación pública, heterosexual. Todos los otros (mujeres, negros, indios, no europeos, etc.), son convertidos, mediante este dispositivo, en objetos de conocimiento, en no sujetos, en seres incapaces de crear un conocimiento válido. La separación entre sujeto y objeto justificará también la exteriorización-objetivación de la naturaleza y su explotación [Lander, 2000].

El nuevo patrón de poder es colonial porque se asienta en una estructura de dominación mundial basada en la idea de raza, la misma que abarcaría más y sería más perdurable que la de clase, en la medida en que las diferencias sociales se justificaban a partir de supuestas diferencias biológicas. Dicha clasificación colonial consiste en la tipificación jerárquica de la población del mundo según la idea de raza, emergida junto con América, en europeos o blancos y no europeos (indios, negros, etc.), como el eje de la distribución de la población en torno de las relaciones de poder, del trabajo y de la experiencia material de la modernidad según las cambiantes necesidades del capital, en cada contexto (momento y lugar) histórico. La categoría heterogeneidad histórico-estructural es muy relevante para nuestro trabajo, pues nos dice que ningún patrón de poder es homogéneo. Tratándose de la mano 
de obra, no se presenta una tendencia a que un tipo de control del trabajo tenga una presencia total, exclusiva, pues siempre hay una articulación entre diversos tipos de control, subordinados a uno específico; a su vez, cada tipo de control del trabajo presenta una diferenciación interna. Por tanto, existe una diversidad de formas de control del trabajo que están articuladas alrededor de una de ellas. Al mismo tiempo que lo económico, es decir, las relaciones en torno al control del trabajo, no definían de manera exclusiva la distribución del poder de la gente en la sociedad, pues había otros ejes no económicos, entre ellos: la raza, el género y la edad. En el caso del capitalismo respecto del control de la mano de obra, afirma Quijano: "No existe una tendencia a la homogeneización hacia la relación capital-trabajo, pues otras formas de control del trabajo coexisten, aunque subordinadas a la anterior. Al mismo tiempo, cada una de las categorías (capital, trabajo, servidumbre, reciprocidad, producción mercantil simple), presenta una heterogeneidad dentro de sí misma. Así, el cambio histórico no puede ser unilineal, unidireccional, secuencial o total [Quijano, 2000]. Por tanto, son evidentes:

(1) la coexistencia y la asociación, bajo el capitalismo, de todas las formas de explotación/dominación del trabajo; (2) en el mundo del capitalismo no existían solamente las clases sociales de "industriales", de un lado, y "obreros" o "proletarios", del otro, sino también las de "esclavos", "siervos", "plebeyos" y "campesinos libres"; (3) las relaciones de dominación originadas en la experiencia colonial de "europeos" o "blancos" e "indios", "negros", "amarillos" y "mestizos", implicaban profundas relaciones de poder, que en aquel periodo estaban tan estrechamente ligadas a las formas de explotación del trabajo que parecían "naturalmente" asociadas entre sí; (4) la relación capital-salario no era el único eje de poder, ni siquiera en la economía, sino 
que había otros ejes de poder que existían y actuaban en ámbitos que no eran solamente económicos, como la "raza", el género y la edad; (5) en consecuencia, la distribución del poder entre la población de una sociedad no provenía exclusivamente de las relaciones en torno del control del trabajo, ni se reducía a ellas [Quijano, 2007a].

La clasificación social se refiere a los lugares y a la función de las personas en el control del trabajo, sus recursos (incluidos los de la naturaleza) y sus productos; del sexo y sus productos; de la subjetividad y sus productos (ante todo el imaginario y el conocimiento), y de la autoridad, sus recursos y sus productos [Quijano, 2007a].

En la etapa previa al capitalismo mundial, dice Quijano [2007a:118-119], "se puede verificar que, en las relaciones de poder, ciertos atributos de la especie han tenido un papel principal en la clasificación social de la gente: sexo, edad y fuerza de trabajo son sin duda los más antiguos. Desde la conquista de América se añadió el fenotipo. El sexo y la edad son atributos biológicos diferenciales, aunque su lugar en las relaciones de explotación-dominación-conflicto está asociado a la elaboración de dichos atributos como categorías sociales. En cambio, la fuerza de trabajo y el fenotipo no son atributos biológicos diferenciales. El color de la piel, la forma y el color del cabello, de los ojos, la forma y el tamaño de la nariz, etc., no tienen ninguna consecuencia en la estructura biológica de la persona, y ciertamente, menos aún en sus capacidades históricas. Del mismo modo, ser trabajador manual o intelectual no tiene relación con la estructura biológica. En otros términos, el papel que tiene cada uno de esos elementos en la clasificación social, esto es, en la distribución del poder, no tiene nada que ver con la biología, ni con la naturaleza. Tal función es el resultado de las disputas por el control de los ámbitos sociales. La naturalización de las categorías sociales que dan cuenta 
del lugar de esos elementos en el poder es un desnudo producto histórico-social. El hecho de que las categorías, que identifican lugares y funciones en las relaciones de poder, tengan la pretensión de ser simplemente nombres de fenómenos naturales, tengan o no alguna referencia real en la naturaleza, es una indicación muy eficaz de que el poder, todo poder, requiere de ese mecanismo subjetivo para su reproducción. Y es interesante preguntarse por qué. Mientras la producción social de la categoría género, a partir del sexo, es sin duda la más antigua en la historia social, la producción de la categoría raza, a partir del fenotipo, es relativamente reciente, y su plena incorporación a la clasificación de las personas en las relaciones de poder tiene apenas 500 años: comienza con América y la mundialización del patrón de poder capitalista.

Desde nuestra perspectiva, sólo los procesos de subjetivación, cuyo sentido es el conflicto en torno de la explotación/ dominación, constituyen procesos de clasificación social. En el capitalismo mundial, la cuestión del trabajo, de la raza y del género, son las tres instancias centrales respecto de las cuales se ordenan esas relaciones conflictivas de explotación/dominación. Ergo, los procesos de clasificación social consistirán, de todos modos, en procesos donde esas tres instancias se asocian o se disocian respecto del complejo explotación/dominación/conflicto. De las tres instancias es el trabajo, esto es, la explotación/dominación, la que se ubica como el ámbito central y permanente. La dominación hace posible la explotación y no se la encuentra, sino muy raramente, actuando por separado. Las otras instancias son, ante todo, instancias de dominación, ya que la explotación sexual, específicamente, es discontinua. Esto es, mientras que la relación de explotación/dominación entre capital-trabajo es continua, el mismo tipo de relación varón-mujer no ocurre en todos los casos, ni en todas las circunstancias; no es, pues, continua. Así mismo, en la relación entre "razas" 
se trata, ante todo, de dominación. En fin, la articulación entre instancias de explotación y de dominación es heterogénea y discontinua. Y, por lo mismo, la clasificación social como un proceso en el cual las tres instancias están asociadas/disociadas, tiene también, necesariamente, esas características [Quijano, 2007a: 117].

\subsection{LA MODERNIDAD INSTRUMENTAL Y LA IDEA EUROCÉNTRICA DE LA IGUALDAD}

Para los efectos de esta investigación acerca del trabajo, es importante plantear que la modernidad europea, en tanto nuevo horizonte histórico de sentido, emerge dentro de la misma colonialidad del poder, aunque ya eurocentrada. Esto es, la modernidad europea es un elemento nuevo de dicho patrón de poder, y es al mismo tiempo un elemento de la colonialidad. De este modo, la modernidad europea se constituye en permanente tensión entre las necesidades de conocimiento instrumental del nuevo poder, del capital, que se expandía en Europa Occidental y una veta utópica inspirada en la conciencia de un horizonte de cambios históricos y alimentada con imágenes del nuevo mundo, especialmente del área andina, pues en ella se evidencia la práctica cotidiana de la reciprocidad y la organización colectiva del trabajo. Así:

de un lado, es entonces que en la emergente Europa Occidental, comienza a expandirse y a desarrollarse la práctica social que se llama el Capital. Es decir, se expande la mercantización de la fuerza viva individual de trabajo, la producción de plusvalor y la acumulación del respectivo lucro. Y son sus correspondientes necesidades intersubjetivas las que llevan a la producción de un modo de conocimiento que será considerado como la "racionalidad científica” y que requiere libertad y autonomía individual 
para su producción y desarrollo. Pero tal "racionalidad" se constituye sobre una episteme racista, como parte de la Colonialidad del Poder, y además metafísica y mística, debido a la hegemonía del radical dualismo cartesiano que separa "razón" de "naturaleza", en esa perspectiva de conocimiento que se proclama "racional" y "científica”. De otro lado, y en el mismo movimiento histórico, los conflictos de poder que se asocian al Capital y a la Colonialidad del Poder, producen también un universo intersubjetivo paradójicamente asociado a tal "racionalidad": las ideas de igualdad social y de solidaridad social, que son propuestas denominadas desde su origen como "utópicas" y que envuelven imágenes sociales referidas a lo que los colonizadores encuentran o creen encontrar en las formas de existencia social de algunos de los pueblos colonizados, en particular en las relaciones de reciprocidad y de comunidad en las regiones que hoy llamamos andinas. La amalgama entre aquella "racionalidad" y esa veta utopística, es lo que emerge y se hace hegemónica como la "Modernidad Europea [Quijano, 2013: 4].

Por tanto, la modernidad y el capitalismo son una coproducción de lo que se llamaría (en términos geoculturales) América y Europa, y no sólo producto de la segunda, pues a diferencia del relato eurocéntrico de la autoproducción de Europa y del capitalismo, Quijano plantea que lo que hoy se denomina América tuvo un lugar activo y fundamental en términos intersubjetivos como materiales. Por un lado, "las ideas centrales de la modernidad, en especial su veta utopística, la igualdad social y la solidaridad social, emergen con América [Quijano, 2013], pues con las prácticas de igualdad, reciprocidad y solidaridad existentes en este mundo, el proyecto de la modernidad experimenta una expansión del imaginario y un desplazamiento en la percepción del tiempo, ubicando ya no en el pasado, sino en el futuro, el lugar de la emancipación humana. Así, 
Quijano [1988: 12] sostiene que el "descubrimiento de América Latina produce una profunda revolución en el imaginario y desde allí en el imaginario del mundo europeizado en la dominación: se produce el desplazamiento del pasado, como sede de una para siempre perdida edad dorada, por el futuro como la edad dorada por conquistar o por construir".

Por otro lado, el capital, en tanto relación social, se concentraba en Europa Occidental, mientras que en este lado del mundo se producían mercancías - minerales y vegetales preciosos - para el mercado mundial y la acumulación capitalista mediante formas de trabajo no pagadas (esclavitud, servidumbre, reciprocidad y pequeña producción mercantil simple) que eran desempeñadas por las "razas inferiores": indios y negros. En este sentido, América Latina desempeñó un importante papel en la creación del capitalismo como sistema mundial, al proveer de minerales valiosos que contribuyeron a la acumulación originaria del capital.

Así, afirma Quijano [2013: 20] que "la expansión y consolidación del capital, racionalidad y modernidad, si bien ocurren en el curso de constitución de "Europa Occidental" y son, en ese específico sentido, "europeos", son igualmente "americanos" pues América es el único espacio/tiempo dominado dentro de la Colonialidad del Poder y Europa Occidental, la nueva sede central de control de este patrón de poder".

El análisis del trabajo desde el siglo xvi a la actualidad no tendría mayor sentido si se hace únicamente desde la perspectiva de la modernidad, es decir, de lo que podríamos llamar historia oficial, la historia universal de la humanidad que nos presenta una narrativa generada en Europa y por Europa. En este relato, evolutivo y unidireccional, el devenir histórico discurre por etapas históricas sucesivas, cada una de las cuales borra del mapa a la anterior y homogeniza, por consiguiente, la realidad social. 
En este sentido, se habla de comunismo primitivo, de esclavismo, feudalismo y capitalismo, siendo este último en tanto progreso y desarrollo, la coronación de todo un derrotero "civilizatorio", cuyos productos concretos se encuentran en Europa y Estados Unidos de América, en tanto logros de la modernidad. Se plantea, además, una existencia social a partir de la igualdad, la autonomía individual y la libertad, con derechos de ciudadanía, con una intersubjetividad basada en el pensamiento racional y en el conocimiento científico. En términos de la discusión respecto al trabajo, esta misma perspectiva homogeneizante se centra en estudiar las formas y mecanismos que condujeron al establecimiento del trabajo asalariado como forma universal y legítima del trabajo en general, basándose en que la sociedad capitalista tiene como único tipo de control del trabajo al capital, ignorando que lo existente en la realidad es el capitalismo, que a partir de la heterogeneidad histórico-estructural de la sociedad es la asociación, bajo la hegemonía del capital, de otras modalidades de control del trabajo, entre ellas, la servidumbre, la esclavitud, la reciprocidad y la pequeña producción simple.

Al mismo tiempo, se constata la existencia de otras maneras de vivir, que, en términos del trabajo, no están centradas en vivir para trabajar sino en trabajar para vivir. Esto significa que es posible tratar el estudio del trabajo no sólo desde la concepción de job-labor en tanto actividad efectuada bajo condiciones de dependencia, de dominación y explotación, sino también desde formas no capitalistas de vida y formas de trabajo sin explotación (work).

El tratamiento desde la segunda perspectiva puede ser emprendido a condición de distanciarse del eurocentrismo, pues según este, la desigualdad natural aristotélica que influyó de manera tan decisiva en el pensamiento de las épocas antigua y medieval, se habría visto debilitada en la modernidad, ya que la propuesta liberal parte de la 
idea de la igualdad formal entre los individuos, quienes son portadores de supuestos derechos e intereses naturales. Según Aguiló [2009: 5]:

la antropología liberal concibe las relaciones sociales como extrínsecas y ajenas al ser humano. Parte del presupuesto según el cual los individuos aislados, sin vínculo comunitario alguno, nacen formalmente libres e iguales. Para legitimar y fundamentar teóricamente la igualdad formal propugnada, los teóricos liberales recurrieron a la tradición iusnaturalista, basada en la suposición de determinados derechos naturales fundamentales. Los derechos, desde los parámetros de explicación de la filosofía política liberal, constituyen espacios de libertad relativa capaces de oponer resistencia a las opresiones de poderes que, libres de límites y mecanismos de control, ponen en peligro la libertad individual. Todo individuo, por el mero hecho de serlo, es portador de unos supuestos derechos e intereses naturales — derecho a la vida, a la libertad y a la propiedad privada individual, entre otros- que anteceden lógicamente a la existencia del orden político instituido. La antropología liberal consagró, de este modo, la igualdad como igualdad natural de todos los seres humanos, debilitando la teoría de la desigualdad natural forjada por filósofos de la Antigüedad, como Platón y Aristóteles, y por los grandes teólogos del cristianismo — San Agustín y Santo Tomás-.

No obstante, a partir del siglo XVI, esta visión aristotélica cobró nuevamente fuerza para legitimar la conquista y el despojo en Abya Ayala (denominada después América) por parte de los iberos, quienes se convertirían en españoles. Así, quienes se beneficiaron del trabajo esclavista (principalmente propietarios de grandes extensiones de tierra) se apoyaron en la noción aristotélica que argumenta que los pueblos cultos deberían dominar a los bárbaros - aun con el uso de la fuerza si fuera necesario-, 
encontrando en este sustrato ideológico la argumentación óptima de su acción esclavista [Zavala, 1968]. Ginés de Sepúlveda se basó en Aristóteles y santo Tomás de Aquino para fundamentar el despojo, la colonización y la inferiorización de los "indios", por "bárbaros". Como sostiene Zavala [1968]: "en su famosa Política, Aristóteles señaló la legitimidad de que lo superior está sobre lo inferior, lo acabado sobre lo inacabado, la razón sobre la barbarie, así como el uso de la fuerza por los hombres civilizados para lograr la sujeción de los bárbaros”. Aquino, por su parte, reafirma la importancia del alma sobre el cuerpo como humanidad:

Y así vemos que en las cosas inanimadas la forma, como más perfecta, preside y domina, y la materia obedece a su imperio; y esto todavía es más claro y manifiesto en los animales, donde el alma tiene el dominio, y es como la señora, y el cuerpo está sometido, y es como siervo. Y del mismo modo, en el alma, la parte racional es la que impera y preside, y la parte irracional la que obedece y le está sometida; y todo esto por decreto y ley divina y natural que manda que lo más perfecto y poderoso domine sobre lo imperfecto y desigual. Esto se ha de entender respecto de aquellas cosas que conservan incorrupta su naturaleza, y respecto de los hombres sanos de alma y de cuerpo, porque en los viciosos y depravados es cierto que muchas veces domina el cuerpo al alma y el apetito á la razón, pero esto es cosa mala y contra naturaleza. Y así, en un solo hombre se puede ver el imperio heril que el alma ejerce sobre el cuerpo, la potestad civil y regia que el entendimiento ó la razón ejercen sobre el apetito, por donde se ve claramente que lo natural y justo es que el alma domine al cuerpo, que la razón presida al apetito, al paso que la igualdad entre los dos ó el dominio de la parte inferior no puede menos de ser perniciosa para todos [Aquino, citado por Sepúlveda, s/f: 292]. 
La "inferioridad natural" o la "desigualdad natural" fundada en diferencias de capacidad intelectual entre los hombres se fue gestando desde el siglo XvI a partir de las diferencias fenotípicas que se evidenciaban entre los conquistadores y los pobladores de este continente, y se establecieron como raza, planteando así que los iberos de tez blanca eran superiores a los nativos de tez marrón, y por tanto, tenían derecho a conquistarlos por su mayor desarrollo cultural y "civilizatorio"1. En la llamada modernidad emergente, la igualdad que se reconocía entre los hombres era una igualdad formal en relación al Estado, pero estaba circunscrita a los europeos y dejaba de lado a los otros: indios, negros y mujeres. En este sentido, racismo y liberalismo son las caras de una misma moneda, como afirma Collier [1999]. Para esta autora, tal afirmación puede sostenerse considerando tanto la lógica cultural propia de la teoría política liberal (la que asocia el nacimiento de iguales con la igualdad ante la ley), como la puesta en práctica de la teoría liberal en los Estados-nación.

En relación al primer aspecto, los filósofos de los siglos XVII y XVIII que defendían la teoría del contrato social, rechazaban la idea de una desigualdad social de origen divino e impuesta legalmente, razones por las cuales los hombres tienen diferentes papeles que desempeñar en la Tierra, de modo que algunos están destinados a gobernar y otros a obedecer. Los filósofos, entre ellos Hobbes, Locke y Rousseau, declararon que Dios había creado a todos los hombres iguales, les había obsequiado con el uso de la razón, misma que distingue a los hombres de las bestias. Como iguales, tanto en fuerza como en razón, los hombres estaban exentos de la obligación de someterse a leyes promulgadas por una persona que

1 En torno a esta discusión es imprescindible la consulta de Dussel [1994], que trata "el encubrimiento del otro". 
se proclamaba rey. Por el contrario, los hombres debían unirse en un contrato social para determinar entre sí las leyes que deben gobernarlos. De aquí se deduce que dichos filósofos liberales contractualistas nunca creyeron que todos los hombres hubieran nacido iguales. Los hombres iguales en los que pensaban eran varones, cabeza de familia, que poseían suficiente propiedad como para no tener que trabajar para otros como sirvientes o asalariados. Durante los últimos tres siglos, la categoría de hombres iguales se ha ampliado merced de las luchas sociales por la democracia, expandiéndose tal categoría a varones sin propiedad, a minorías étnicas o raciales, y finalmente, a las mujeres. No obstante, la lógica cultural liberal persiste, pues si Dios-naturaleza creó iguales a todos los hombres, aquellos que manifiestamente no son iguales, no son hombres. Estos no hombres carecen de la capacidad de raciocinio que sustenta el dominio de sí. Entre los siglos XVII y XVIII los sirvientes y los asalariados eran excluidos del contrato social porque, aun cuando contaran con el uso de la razón, no estaban en condiciones de ejercerla, pues debían obedecer a sus amos y patrones [Collier, 1999]. En este sentido, Mignolo [2007] destaca que en el pensamiento de Rousseau la desigualdad natural era algo indiscutible. Rousseau [citado por Mignolo] concebía:

en la especie humana dos clases de desigualdad: una que llamo natural o física porque ha sido establecida por la naturaleza y que consiste en la diferencia de edades, de salud, de las fuerzas del cuerpo y las cualidades del espíritu o del alma; otra, que puede denominarse desigualdad moral o política, pues depende de una especie de convención y está establecida, o cuando menos autorizada, por el consentimiento de los hombres. Esta última consiste en los diferentes privilegios de los que gozan unos en detrimento de los otros, como ser más ricos, más honrados, 
más poderosos que ellos, o, incluso, hacerse obedecer [ibíd.: 150]. ${ }^{2}$

Para Rousseau, preguntarse por el origen de la desigualdad natural no tenía sentido, puesto que esa interrogante, según él, estaba ya respondida de antemano por la simple definición de la palabra: la desigualdad es natural, y no hay nada más que preguntar.

Es aún más absurdo preguntarse — continúa Rousseau—si hay alguna conexión esencial entre las dos desigualdades, puesto que hacer esta pregunta significaría preguntar si quienes están en el poder y en posición de mandar son necesariamente mejores que aquellos que están en posición de obedecer. Este tipo de preguntas, concluye Rousseau, sería adecuado en una discusión de los esclavos en una audiencia con su amo, pero totalmente inconducente e incorrecta si tales preguntas fueran dirigidas a "hombres razonables y libres en búsqueda de la verdad” [ibíd.: 150].

Mignolo sostiene que, como tantos otros ilustrados del siglo XVIII (Kant entre ellos), Rousseau condenó la esclavitud, pero tal condena no se derivaba de que se aceptara sin más la igualdad de los europeos y los esclavos africanos. La "desigualdad natural" es un principio racional suficiente para distinguir en el mismo plumazo lo injusto de la esclavitud, pero también la inferioridad de los negros africanos [Mignolo, 2007].

Respecto al segundo punto, se planteaba que, partiendo de la igualdad, todos los hombres debían elaborar sus propias leyes y aplicarlas por igual a todos, sin privilegios legales y especiales. Por tanto, si la ley brinda un trato igual a todos, las desigualdades observables no derivan

2 De este punto crucial pueden verse Duchet [1976] y el libro editado por Ward y Lott [2007]. 
de la ley, sino que son un reflejo de las desigualdades preexistentes al Derecho, tal como diferencias físicas y mentales predeterminadas por Dios o la naturaleza, o que derivan del libre albedrío de los individuos. De este modo, si los miembros de minorías étnicas o raciales, a pesar de gozar de igualdad ante la ley, no conseguían el éxito económico de las clases dominantes, su fracaso se debía a que dicha minoría carecía de la capacidad o voluntad para triunfar [Collier, 1999].

Los argumentos críticos anteriores muestran con claridad que la teoría política liberal, y en general, la visión liberal, son eurocéntricas porque no dan cuenta de lo que históricamente ha ocurrido en el mundo desde el siglo XVI. En este sentido, es posible constatar que a lo largo del periodo comprendido entre el siglo XVI y el XIX, el trabajo manual fue revalorizado y colocado con luminosidad en la escena social, atribuyéndosele, en su faceta de asalariado, la exclusividad en la creación de riqueza, bajo la denominación de trabajo productivo. No obstante, se aprecia que el trabajo manual ocupaba un lugar subordinado en la fábrica y en la sociedad, esto es, en las relaciones de mando y obediencia. Por tanto es posible plantear la pregunta: ¿más allá de la idea abstracta de igualdad que la modernidad vinculada a la razón histórica trataba de traducir en experiencia cotidiana y práctica social europea, no seguía vigente entre la burguesía el desprecio histórico (registrado desde la conformación de sociedades clasistas) por el trabajo manual y por quienes lo ejercían, debido a que eran considerados inferiores por naturaleza? ${ }^{3}{ }^{2} \mathrm{No}$ abrevaba esta repulsión de las clases dominantes por el trabajo asalariado de la visión aristotélica de la desigualdad por naturaleza? Y por tanto, la idea de raza como eje universal de clasificación social jerárquica a partir del siglo XVI, ¿no se elaboró a partir de ese sustrato ideológi-

3 Ver Jaccard [1977] y Ramella [2011]. 
co que tenía ya una larga existencia? No es el propósito central de este trabajo hacer una discusión profunda de tales interrogantes que se asoman a partir de la aguda teoría de la colonialidad del poder, pero sí tratarlas en términos generales e invitar a discutirlas de manera más sistemática, pues hay ciertas evidencias acerca del prejuicio aristocrático y burgués en torno al trabajo manual y quiénes eran. Al respecto, la siguiente cita de Jaccard [1977: 299] es sugerente:

Desde Federico Engels, suele hacerse una distinción fundamental entre el socialismo utópico, profesado por los jefes del movimiento obrero francés a mediados del siglo XIX, y el socialismo con pretensiones científicas, representado precisamente por Engels y Carlos Marx. Sin embargo, entre los rasgos que unen a todos estos hombres y sus doctrinas, es preciso destacar su común exaltación del trabajo. En el momento en que la alta burguesía, siguiendo en ello el ejemplo de la nobleza de otros tiempos, se enorgullece de tener las manos blancas, el pueblo se inspirará en una mística del trabajo que le hará olvidar la dureza de su condición. Es durante la época de 'la gran penuria obrera', entre los años 1830-1870, cuando aparece realmente el socialismo moderno, con sus reivindicaciones y su apología del trabajador.

\subsection{Debate acerca del eurocentrismo en Marx}

Es conocida la perspectiva evolucionista que inspiraba el análisis del capitalismo en Marx. Para él, la experiencia inglesa definía el derrotero que debían seguir los demás países de Europa y del mundo, puesto que Inglaterra representaba el despliegue más acabado del desarrollo de las fuerzas productivas, de la decantación social entre burgueses y proletarios, y del liberalismo político. En 
relación a este espejo de evolución, progreso y civilización, Marx evaluaba las demás experiencias del mundo, ubicadas temporalmente, y en términos civilizatorios, en el pasado.

Marx afirmaba en el prefacio de la primera edición de El capital: "lo que he de investigar en esta obra es el modo de producción capitalista y las relaciones de producción e intercambio a él correspondientes" [1982: 6]. Tomando el caso de Inglaterra que Marx no dudaba se extendería por toda Europa y el mundo entero como algo inevitable y necesario. Y aludiendo al objetivo de su investigación, sostenía: "trata de estas leyes mismas, de esas tendencias que operan y se imponen con férrea necesidad", añadiendo que "el país industrialmente más desarrollado no hace sino mostrar al menos desarrollado la imagen de su propio futuro" [1982: 7]. Y luego comentaba que "aunque una sociedad haya descubierto la ley natural que preside su propio movimiento - y el objetivo último de esta obra es, en definitiva, sacar a la luz la ley económica que rige el movimiento de la sociedad moderna- no puede saltearse fases naturales de desarrollo ni abolirlas por decreto. Pero puede abreviar y mitigar los dolores del parto" [1982: 8].

En este mismo sentido, la expansión del capitalismo colonial, en el caso de India, por ejemplo, era considerada necesaria e inevitable, aunque ocasionara sufrimiento a sus pobladores. Algo análogo se pensaba respecto del despojo territorial, en este caso, sufrido por México por parte de Estados Unidos de América en 1847, y en relación con las sociedades latinoamericanas recién independizadas, que carecían de proyectos nacionales.

Para examinar estas tensiones eurocéntricas en el pensamiento de Marx, son valiosos los estudios llevados a cabo por Shanin [1990], Fontana [1982], Merlo [2013], Lander [2008] y Quijano [2000 y 2007a]. 
EL MARX NO EUROCÉNTRICO: SHANIN, MERLO Y FONTANA

Tanto Shanin como Merlo advierten un juicio en Marx marcadamente negativo y eurocéntrico respecto de lo no capitalista europeo (Shanin), y lo no europeo (Merlo). Ambos autores hacen una reflexión crítica del pensamiento de Marx desde el marxismo, en la idea de explicar y encontrar salidas al eurocentrismo desde el propio Marx, pues es conocido que en el tramo último de su vida éste era consciente de las dificultades de la visión evolutiva, del progreso y de la civilización dominante en que se basaba para valorar el desarrollo del capitalismo en el mundo como una etapa previa a la creación del comunismo. Por su parte, Fontana destaca la influencia decisiva de la visión evolutiva-civilizatoria de la historia - la teoría de los cuatro estadios - centrada en lo económico de Smith en Marx. En contraste, Lander [2008] y Quijano [2000] coinciden en señalar que Marx, como resultado de su tiempo intelectual, tenía como base una epistemología eurocéntrica, sobre la que fue adquiriendo conciencia en el último tramo de su vida, pero que no pudo resolver.

La visión evolutiva de la historia hizo que Marx considerara, como sostiene Merlo - basándose en Aricó [1992]_, que los procesos políticos de conformación de las naciones en América Latina carecían de una capacidad nacional que sí existía en los casos de China, India, Rusia e Irlanda. "Esto se debería a una fuerte influencia conceptual hegeliana, la misma que también se hizo evidente en la utilización de conceptos como 'naciones históricas y naciones sin historia', que determinan una diferenciación entre las naciones que juegan un rol relevante en la historia universal (las naciones de Europa occidental) y aquellas, como las latinoamericanas, que sólo son el eco de otras realidades más racionales" [2013: 82]. No obstante, Merlo rechaza la visión de Marx como un pensador 
eurocéntrico, sosteniendo que se registraron significativos cambios en su pensamiento, pues "de la creencia en su 'etapa madura', en el progreso, en la necesidad del dominio sobre la naturaleza, en la revalorización de la tecnología productiva pasa, en su 'etapa tardía' a relativizar la creencia en la necesidad histórica de un solo camino al socialismo" [2013: 84].

Mientras tanto, Shanin [1990] afirma que el pensamiento de Marx registró una profunda tensión respecto del eurocentrismo a partir de la década de los años setenta del siglo XIX, cuando Marx reflexionó críticamente respecto de la universalidad del evolucionismo histórico, al analizar la experiencia de la Rusia europea pero "atrasada"; pues se desplegaron las dificultades del análisis marxista respecto de las sociedades no europeas, entre ellas la india y las latinoamericanas, las mismas que por encontrarse en un estadio histórico anterior (precapitalista), debían ser dominadas y civilizadas por países capitalistas "adelantados". Para Shanin, la fuerza de El Capital se encuentra, por un lado, en la crítica amplia, sistemática, histórica y con sustento empírico de la forma en la que sociedad capitalista contemporánea de Gran Bretaña había funcionado a nivel social, y por otro, en la aplicación general que podía tener este modelo para otras sociedades en las que el capitalismo ha ido en rápido y manifiesto ascenso desde entonces. Al mismo tiempo, las limitaciones de la propuesta tenían que ver con que su argumentación se basaba en el conocimiento de su tiempo, especialmente de las filosofías políticas de evolución y de progreso de la Revolución francesa; así, Shanin sostenía que este conocimiento tenía como un aspecto central "el evolucionismo, el arquetipo intelectual de aquellos tiempos, tan prominente en los trabajos de Darwin como en la filosofía de Spencer, en el positivismo de Comte y en el socialismo de Fourier y de Saint Simon. El evolucionismo es, esencialmente, una solución combinada con los problemas de la heteroge- 
neidad y del cambio. La diversidad de formas, física, biológica y social se ordena y explica por la hipótesis de un desarrollo estructuralmente necesario mediante estadios que el método científico debe descubrir. La diversidad de los estadios explica la diversidad de las formas. La fuerza de esta explicación reside en la aceptación del cambio como parte de la realidad. Su debilidad principal es el determinismo optimista y unilineal usualmente implícito en ella: el progreso a lo largo de los estadios significaba también el ascenso universal y necesario a un mundo más agradable para los humanos o incluso para el 'espíritu absoluto' o el mismo Dios" [1990: 15].

Por su parte, Fontana [1982] hace un análisis muy sugerente respecto de la influencia de Smith en el pensamiento de Marx. Smith es el hombre de ideas más importante de la Ilustración escocesa, que en La riqueza de las naciones sintetizó la concepción Whig de la sociedad inglesa - la defensa de la propiedad privada era el fundamento del orden civil—, las ideas históricas de Hume (evolutivas y donde la división del trabajo y el intercambio son centrales) y la física social de Montesquieu, situando el concepto de progreso desde un punto de vista económico que mostraba la evolución de la humanidad [Fontana, 1982: 89-90]. En Smith, la historia es la genealogía del capitalismo, de su funcionamiento y la promesa de prosperidad general, como consecuencia del propio desarrollo capitalista [Fontana, 1982: 148]. A partir de una reflexión temporalmente más abarcadora, Fontana sostiene que:

Smith logró hacernos compartir su visión lineal del pasado, que se establece como una ruta marcada por revoluciones tecnológicas que abren etapas sucesivas de ascenso para el hombre. Nos ha hecho aceptar, con ello, su visión del progreso, que consiste en definir como avanzado todo lo que conduce hacia el capitalismo y la industrialización, sin aceptar que puedan existir otras formas válidas de confi- 
guración de la economía y de organización de la sociedad, a las que pudiera llegarse por otros caminos, descalificando las vías alternativas como retrógradas o impracticables (utópicas) (...) ha corrompido nuestros proyectos para el futuro, que nos hemos acostumbrado a ver como una superación que nos conducirá a una etapa más elevada de la industrialización, incapacitándonos para plantear una auténtica alternativa al capitalismo [Fontana, 1982: 97].

Fontana sostiene que el materialismo histórico contiene una concepción de la historia que nos muestra la evolución humana a través de unas etapas de progreso que no son definidas fundamentalmente por el grado de desarrollo de la producción, sino por la naturaleza de las relaciones que se establecen entre los hombres que participan en el proceso productivo [Fontana, 1982: 149]. En este sentido, la visión de Marx se asemeja a la propuesta smithiana en la mirada evolutiva de la historia y en el optimismo de las posibilidades de la ciencia y la tecnología. Fontana sostiene que la visión del futuro de Marx y Engels acepta una parte de la promesa smithiana, cambiando los términos en que está formulada. Las fuerzas productivas que el capitalismo ha movilizado, potenciadas por la ciencia, pueden asegurar la prosperidad para todos, a condición de abolir el marco social capitalista. Esta fe ingenua en el progreso tecnológico se encuentra ya en "Esbozo de crítica de la economía política” del joven Engels, y no parece haber sido abandonada más tarde. Viviendo en un mundo que todavía no ha experimentado las consecuencias de la expansión del capitalismo a escala mundial, no adivinan que ésta no va a reproducir sencillamente el esquema industrializador británico en cada país — como parece estar sucediendo, en su tiempo, en Francia y Alemania-, sino que puede tener efectos depredadores en otras partes del mundo [Fontana, 1982: 151]. 
¿Cómo se explica Fontana esta visión equivocada de Marx en términos del conocimiento? La respuesta es semejante a la de Shanin: Marx y Engels se nutrieron de los conocimientos históricos de la historia contemporánea a su época, conocimientos que ellos enriquecieron y reinterpretaron genialmente, pero que eran eurocéntricos:

la investigación histórica de su tiempo era descaradamente europeocentrista, porque necesitaba justificar el sometimiento de los 'pueblos sin historia' a los que obligaba a pasar de la "barbarie" a la "civilización", y ello tendía a favorecer una visión del pasado como la de la escuela escocesa, que conducía la evolución histórica hacia la culminación representada por el capitalismo, la industrialización y la ciencia moderna [Fontana, 1982: 152].

En el último periodo de su obra, Marx dio otro paso adelante hacia una conceptualización más compleja y realista de la heterogeneidad mundial de las formas sociales, su dinámica y su interdependencia. El cambio en la perspectiva de Marx se produjo como una reflexión acerca de El Capital (vol.1, 1867) y evidenció la nueva experiencia y el testimonio de los años 1870 . El cambio de perspectiva de Marx respecto del evolucionismo se explicaba por su nueva visión respecto de Rusia, ya que los populistas rechazaban la necesidad de que la sociedad pasara por el capitalismo para luego luchar por la revolución socialista. Para esto, los populistas planteaban una alianza de clases entre campesinos (la mayor parte de la población), asalariados e intelectuales que permitiría saltar sobre el estadio del capitalismo. Las comunas tenían tres quintas partes de la tierra cultivable del país, se hacían trabajos colectivos en tierras comunales; tomaban decisiones por medio de asambleas y estaban encargadas de la provisión de servicios básicos [Shanin: 1990: 18]. 
Entrar en contacto con los populistas rusos respecto de la comuna rusa y ver la potencialidad revolucionaria que ésta tenía, haría que Marx tratara de alejarse de la visión evolutiva y del progreso unilineal. Así, Marx expresaría:

remontando el pasado remoto, hallamos que en todas partes de Europa Occidental la propiedad comunal de tipo más o menos arcaico; ha desaparecido por doquier con el progreso social. ¿Por qué ha de escapar a la misma suerte tan sólo en Rusia? Contesto: Porque en Rusia, gracias a una combinación única de las circunstancias, la comunidad rural, que existe aún a escala nacional, puede deshacerse gradualmente de sus caracteres primitivos y desarrollarse directamente como elemento de la producción colectiva a escala nacional. Precisamente merced a que es contemporánea de la producción capitalista, puede apropiarse todas las realizaciones positivas de ésta, sin pasar por todas sus terribles peripecias. Rusia no vive aislada del mundo moderno; tampoco es presa de ningún conquistador extranjero, como ocurre con las Indias Orientales [Marx, 1871, 1980: 85].

\section{LANDER Y QUIJANO: EL EUROCENTRISMO EN MARX}

Lander y Quijano, a diferencia de Merlo, Shanin y Fontana, sostienen que el pensamiento de Marx, pese a sus esfuerzos, tenía una epistemología eurocéntrica.

Lander [2006 y 2008] reflexiona en torno a la obra de Marx desde una postura crítica al eurocentrismo, sosteniendo que:

Las verdades fundamentales sobre las cuales se construye el edificio teórico de Marx, las ideas más significantes y apasionantes del siglo pasado (progreso, ciencia, desarrollo progresivo de las fuerzas productivas, industrialismo, verdad, libertad y felicidad a través de la abundancia) han 
hecho o comienzan a hacer aguas. Aquellas ideas que sintetizadas, armadas, constituyeron los pilares de un asombroso edificio teórico, aquellas formulaciones que constituían la fuerza fundamental de esa increíble obra de síntesis, se han convertido hoy en su contrario. Lo que ayer era fuente de fuerza, hoy es fuente de debilidad. Los cimientos del edificio no solo no resultaron tan eternos como se creía, sino que se resquebrajan aceleradamente ante nuestros ojos [Lander, 2008: 16-17].

Un ángulo del análisis crítico de Lander acerca del pensamiento de Marx se refiere al modelo de producción de conocimiento, sosteniendo que el armazón epistemológico en el que se sostenía Marx corresponde a la ciencia positiva. Al respecto, Lander plantea que:

La crítica a la sociedad capitalista pasa necesariamente por la crítica a sus formas de conocimiento. Se supone que La contribución a la crítica de la economía política busca precisamente eso, la crítica al conocimiento de la sociedad burguesa en cuanto naturalizador y legitimador de las relaciones de dominación de dicha sociedad. Sin embargo, el propio Marx no logra superar —ni asumir plenamente en sus dimensiones epistemológicas- la tensión entre la crítica al conocimiento de la sociedad capitalista, como dimensión medular de la crítica al capitalismo, y la búsqueda de la construcción de un edificio científico a partir de los moldes epistemológicos y criterios de cientificidad propios de la sociedad capitalista, esto es, la ciencia positiva. Esta tensión corresponde grosso modo a la diferencia entre las perspectivas epistemológicas implícitas o explícitas que se encuentran, por un lado, en los textos más personales, más exploratorios, más filosóficos de Marx —como los Manuscritos de París de 1844, los Grundrisse, el capítulo VI inédito de El Capital — y, por el otro, en la presentación más formalizada, más científica de su trabajo, que se observa en 
buena parte de El Capital. Esta búsqueda de legitimación de la crítica a partir de los propios criterios de validación del conocimiento de la sociedad que se critica y se busca superar radicalmente constituye un límite severo a la crítica marxista de la sociedad capitalista. Es esta vertiente epistemológica cientificista, ya presente en Marx, la base de la construcción de todo el inmenso andamiaje del llamado socialismo científico, que incorpora en forma no cuestionada el modelo de producción de conocimiento característico de la ciencia positiva (dualidad razón-sujeto/ objeto; privilegio de un sujeto histórico particular, y construcción de todos 'los Otros' como objetos del conocimiento, como incapaces de producir conocimiento válido; perspectiva eurocéntrica de la Historia Universal; etcétera) [Lander, 2008: 222-223]. ${ }^{4}$

Quijano analiza la forma en que para Marx se constituyen la dominación y explotación capitalistas y la función que cumple el trabajo en esta discusión, afirmando que, según Marx, es el ámbito primado de toda sociedad, y el control del trabajo, ámbito primado en todo poder social. Quijano halla dos problemas en la propuesta marxiana. Respecto del primero afirma que es cierto que la experiencia del poder capitalista mundial, eurocentrado y colonial-moderno, muestra que el control del trabajo es el factor primado en este patrón de poder: éste es, en primer término, capitalista. En consecuencia, el control del trabajo por el capital es la condición central del poder capitalista. Pero en Marx implica, por una parte, la homogeneidad histórica de éste y de los demás factores, y por otra, que el trabajo determina, todo el tiempo y de modo permanente, el carácter, el lugar y la función de todos los demás ámbitos en la estructura de poder. Sin embargo,

4 Una crítica aguda a la visión histórica de Marx respecto de lo necesario y progresivo del desarrollo capitalista puede verse en Federici [2013: 155-160]. 
afirma Quijano, si se examina de nuevo la experiencia del patrón mundial del poder capitalista, nada permite verificar la homogeneidad histórica de sus componentes, ni siquiera de los fundamentales, sea del trabajo, del capital, o del capitalismo; por el contrario, dentro de cada una de esas categorías no sólo coexisten, sino se articulan y se combinan todas y cada una de las formas, etapas y niveles de la historia de cada una de ellas. Por ejemplo, el trabajo asalariado existe hoy, como al comienzo de su historia, junto con la esclavitud, la servidumbre, la pequeña producción mercantil y la reciprocidad. Y todos ellos se articulan entre sí y con el capital. El propio trabajo asalariado se diferencia entre todas las formas históricas de acumulación, desde la llamada originaria o primitiva, la plusvalía extensiva, incluyendo todas las gradaciones de la intensiva y todos los niveles que la actual tecnología permite y contiene, hasta aquellos en que la fuerza viva de trabajo individual es virtualmente insignificante. El capitalismo abarca, tiene que abarcar, todo ese complejo y heterogéneo universo bajo su dominación [Quijano, 2007a: 100-101].

\subsection{RAZÓN HISTÓRICA, CIVILIZACIÓN Y PROGRESO. \\ El CAPITALISMO COMO INEVITABILIDAD Y NECESIDAD. LA RUINA DE LA RAZÓN HISTÓRICA Y EL PREDOMINIO DE LA RAZÓN INSTRUMENTAL}

La crítica radical al capitalismo hecha por Marx se nutre de las ideas de la Ilustración, principalmente la francesa, que contribuyeron a darle contenido a la razón histórica, un horizonte de sentido histórico orientado hacia la emancipación humana de todo tipo de opresión y explotación. De manera previa al análisis del concepto de trabajo en Marx, es importante presentar un rápido panorama de la emergencia de la razón histórica como proyecto de la 
modernidad en contraposición a la razón instrumental, a partir de las ideas de la Ilustración francesa, y teniendo en cuenta las limitaciones de la propia Revolución francesa para avanzar hacia una sociedad emancipada. Están incluidas en el ámbito de la Ilustración, según Fontana [1982: 60]:

las ideas que buscaban una reforma de la estancada sociedad feudal y que se ubican temporalmente entre la revolución inglesa del siglo XVII y la francesa del siglo XVIII. La primera abrió un proceso de cambio político y económico que puso a Inglaterra por delante de sus pares europeos. Los ilustrados no supieron entender el nexo que existía entre revolución y progreso y trataron de alcanzar este último por medio de reformas que no afectaran el orden social vigente. La revolución francesa mostró inviable tal proyecto y que debían incluirse cambios radicales en la propiedad y el establecimiento de nuevas formas de organización política. De este modo se plantearía un programa revolucionario burgués que hiciera posible un cambio controlado.

En la idea de dos sendas distintas de la Ilustración y de la modernidad (que se plantearon al analizar el concepto de trabajo de Smith, en el apartado anterior), Fontana sostiene que "no es posible seguir considerando conjuntamente a los autores franceses y británicos del siglo XVIII, como se suele hacer en la mayor parte de los libros sobre la Ilustración” [1982: 82].

Ambos grupos de autores provenían de situaciones históricas distintas, pues Inglaterra presentaba una sociedad móvil y tenía una monarquía constitucional, en tanto que Francia tenía una estratificación rígida de órdenes feudales y una monarquía absoluta. La Ilustración inglesa (y escocesa) creó la idea de progreso, el liberalismo económico y la visión histórica (evolutiva), mientras que la francesa generó la idea de naturaleza, la propuesta 
económica fisiográfica y la concepción de la historia de Voltaire y Montesquieu, encaminada no a describir, sino a comprender la sociedad de su época. La escuela histórica escocesa llevó a cabo la tarea de gestar una visión del mundo que legitimara el nuevo patrón de poder capitalista: "la lógica del capitalismo debía ser inculcada a quienes no eran sus beneficiarios directos: se hacía necesario elaborar una visión del mundo que pudiese ser universalmente aceptada, incluso en los pobres y explotados, a quienes se les ofrecería un futuro lleno de promesas a cambio de su conformidad con el presente" [Fontana, 1982: 82]. Esta visión comenzó como una investigación acerca del entendimiento humano, prosiguió con una reinterpretación de la historia y acabó cristalizando en una economía política. Para esto se tuvo que concebir la vida económica como parte del orden natural, lo que requería establecer una pauta consistente de la conducta humana. [Fontana, 1982: 82].

Los ilustrados continentales, entre ellos los franceses, compartían con los escoceses la asociación entre grado de desarrollo económico y formas de organización de la sociedad, del cuerpo legal y de la política. No obstante, a diferencia de los escoceses, no creían que bastara el crecimiento económico para lograr los cambios sociales, pues los sectores dominantes resistirían ser desalojadas del poder, de modo que era necesaria la acción política, es decir, la revolución, para encontrar la senda del progreso económico, de modo que la política no era un elemento secundario como sostenía la corriente escocesa, sino el espacio más trascendente de acción humana. La corriente francesa tenía varias vertientes, entre las que destacaban la que buscaba repetir el camino inglés capitalista y la que sostenía la existencia de otras posibilidades de progreso y organización social, que tenía la idea de apoyarse en el campesinado para construir una sociedad igualitaria, basada en la formas comunitarias de trabajo y apropiación, 
visión que se asentaba en la realidad de la comunidad agraria de mediados del siglo xvIII, que presentaba obligaciones comunitarias, límites a la propiedad privada y tenía tierras en explotación colectiva. No obstante, la mayoría de revolucionarios, representantes de una burguesía en ascenso optaron por el camino normal del desarrollo capitalista y se opusieron a cualquier proyecto de ley agraria y a los planteamientos económicos igualitarios, y luego a todo intento radical que trastocara la dominación burguesa. De la otra corriente se desprendieron segmentos que articularon la lucha antifeudal y los intereses de las clases campesinas y urbanas, que condujeron al socialismo y a la idea comunista del siglo XIx [Fontana, 1982: 136]. A partir de los años treinta del siglo XIX, ante el crecimiento de los problemas de pauperización y concentración de la riqueza en Alemania, Gran Bretaña y Francia, se registró una creciente consciencia de que el capitalismo no traería la felicidad para todos como lo había afirmado Smith. [Fontana, 1982: 135-137]. De la derrota de las aspiraciones revolucionarias de 1830 y la consciencia del fracaso social del capitalismo, que no es un sistema para la prosperidad general sino una forma de explotación, nació una transformación de los planteamientos revolucionarios que buscaban profundizar la línea más radical de la Revolución francesa en una orientación anticapitalista [Fontana, 1982: 137].

No obstante, la razón histórica que inspiraría las luchas revolucionarias estaba permeada por el cientificismo propio del ambiente intelectual y político del siglo XIX y de las ideas de civilización y progreso gestadas durante la Ilustración, y al final de ésta, en la Revolución francesa. Esto significaba rechazar la dominación y explotación del capitalismo, pero en el imaginario de abundancia material del progreso y de la civilización que podían conseguirse mediante el desarrollo de las fuerzas productivas. En otras palabras, la sociedad comunista debía ser construida a 
partir del avance científico y tecnológico que permitiría un incremento gigantesco en las capacidades productivas de la humanidad. No se cuestionaban la tecnología y la maquinaria, sino su uso capitalista. Tampoco se planteaba una distancia respecto de los medios y los fines de las sociedades capitalistas más emblemáticas (Inglaterra en el siglo XIX y Estados Unidos de América a principios del xx). Desde esta perspectiva, el Estado debía tener un rol de primera importancia en la construcción de la sociedad comunista.

Carr [1985: 30-31] sostiene que la Revolución francesa se convirtió en el modelo de revolución hasta principios del siglo xx, ya que por constituir el primer derrumbamiento político total y violento del orden social y político de los tiempos modernos, tuvo un efecto extraordinario en la historia moderna, en tres vertientes: a) convirtió la libertad e igualdad en derechos humanos fundamentales y metas políticas comúnmente admitidas. La idea de justicia social, tenuemente esbozada en Inglaterra en el siglo XVII halló una más concreta manifestación en la ideología igualitaria de los revolucionarios, y aunque aquellas demandas fuesen aplastadas una vez más cuando adoptaron una forma concreta, la idea de igualdad jamás pudo borrarse de la trinidad revolucionaria, b) proyectaba sus ideales hacia el futuro más que al pasado, preparando así el camino para una doctrina del progreso. Más que ninguna persona, Condorcet señaló el desplazamiento de la edad de oro de la humanidad, trasladándola del pasado al futuro, y c) elevó el concepto de productividad a un nuevo y central lugar dentro de los hechos humanos. En la sociedad jerarquizada del antiguo régimen, el interés gubernamental por los asuntos económicos se limitaba a la percepción de las rentas para enfrentar los gastos administrativos y del ejército.

El mismo autor sostiene que desde el siglo XVI se registra una línea evolutiva que parte del concepto de 
administración del patrimonio del príncipe, y llega al de eficiencia administrativa del Estado, con el fin de contribuir a alcanzar las necesidades financieras del Estado. Fueron los fisiócratas y Smith quienes sostuvieron que la riqueza de las naciones no proviene del comercio sino de la producción y que se debe distinguir entre gasto de consumo y gasto de inversión, este último, vital para incrementar la producción, convirtiendo la productividad de toda la sociedad en la preocupación de la economía política [Carr, 1985: 28-30].

Así, la Revolución francesa se presentaba como la primera ocasión para ir plasmando la razón histórica, la búsqueda de la sociedad emancipada, y de la igualdad social, a partir del ejercicio de la razón. El proyecto emancipatorio trasladaba su mirada al futuro, y partía desde su tiempo intelectual, el tiempo del progreso, de la industrialización, y de la búsqueda de mecanismos para incrementar de modo incesante la productividad, y por tanto, la riqueza.

Mucho se ha dicho en torno a que la sociedad rusa no presentaba las características básicas para el cambio societal, pues era "atrasada", con estructuras "arcaicas"; el desarrollo del capitalismo era incipiente y débil la presencia cuantitativa del proletariado, y que estas razones, aunadas a la guerra contra los opositores internos y las agresiones imperialistas, serían importantes para explicar los desalentadores resultados de esta experiencia revolucionaria: el crecimiento del Estado, el omnímodo poder del partido, la planificación económica burocrática, la cancelación de las libertades políticas básicas, el control de los sindicatos, la existencia de campos de concentración para los opositores, la eliminación física de segmentos de ellos. Todo esto, en búsqueda de la sociedad socialista industrializada, de la abundancia material, que debía estar a las alturas de los logros económicos de Estados Unidos de América. Opositores como el propio Trotsky no cuestionaban la senda industrializadora forzada, sino 
la falta de democracia política, y lo que planteaban era una revolución política que modificara el verticalismo del Estado obrero reformado. Luego vendrían sucesos que evidenciarían con mayor claridad este proceso de instrumentalización de la razón histórica: el pacto entre Hitler y Stalin instantes antes de que estallara la Segunda Guerra Mundial, la represión brutal de movimientos sociales que buscaban reorientar el proceso hacia una mayor democratización, siendo la invasión a Checoslovaquia, en 1968, el mayor ejemplo al respecto, en momentos en que desde los Estados capitalistas también se reprimían protestas de corte anticapitalista, como ocurrió con el Mayo francés ${ }^{5}$.

En los términos de esta investigación, en el extravío de la razón histórica tiene que ver la asociación creciente que fue tomando el proyecto emancipador entre razón y poder y no entre razón y liberación, como era su sentido primigenio. Esta situación llegó a su máxima expresión con el desmoronamiento del bloque socialista a fines de la década de los ochenta del siglo pasado, y la crisis intersubjetiva asociada. Para muchos en el mundo, el fin de la URSs era el fin de todo proyecto emancipador y el avance del capitalismo financiero y sus políticas neoliberales parecía indetenible, por lo que se hablaba, en los círculos del poder dominante, del fin de la historia.

No fue así, pues el patrón de poder colonial-moderno, capitalista y eurocentrado, ha profundizado su crisis desde sus cimientos: se cuestiona con mayor amplitud la legitimidad de la raza como constructo mental que establece una clasificación social jerárquica mundial; el trabajo asalariado como eje articulador de las otras formas de control del trabajo, dada la creciente amplitud del des-

5 Acerca de esta historia puede consultarse: Trotsky [2000-1937], Deutscher [1963] y la reciente novela El hombre que amaba a los perros de Leonardo Padura. 
empleo estructural en el capitalismo, y el eurocentrismo en tanto manera de producir conocimiento.

Por el contrario, con las resistencias a las tendencias más destructivas del capitalismo, a lo largo de estas últimas décadas se ha ido configurando un amplio conjunto de movimientos sociales con una perspectiva anticapitalista, que van produciendo un nuevo horizonte histórico de sentido, el Buen vivir.

Esta perspectiva abre las posibilidades de una reelaboración de la razón histórica, en la que el sentipensamiento (el sentipensar), esto es, que la amalgama de las perspectivas procedentes de la cultura occidental y las culturas originarias, pueda conducirnos a un puerto más esperanzador que nos acerque al horizonte emancipatorio, combinando una racionalidad liberadora (entre los humanos) y una racionalidad solidaria (entre los humanos con la Madre Tierra). 


\section{La colonialidad del trabajo en Occidente}

\subsection{ANTES DE LA COLONIALIDAD-MODERNIDAD}

La idea dominante y eurocéntrica del trabajo parte de Grecia, en tanto la cuna de la civilización occidental. En dicho momento histórico, se sostiene, había una valoración negativa del trabajo, la que contrasta con la apreciación positiva que fue adquiriendo a partir de la denominada modernidad. En esta sección analizaremos las visiones del trabajo en el periodo previo a la colonialidad-modernidad, estudiando las ideas de algunos de los personajes más conspicuos que reflexionaron en torno al trabajo, entre ellos Aristóteles, san Agustín y santo Tomás de Aquino.

De manera previa a esto, es importante señalar que la literatura eurocéntrica tocante al trabajo establece como el punto fundacional de la cultura humana el mundo griego, ignorando la experiencia histórica de otras partes del planeta y otras culturas, denominadas sociedades primitivas $^{1}$, caracterizadas por la vida en comunidad, el trabajo colectivo, la relación de complementariedad con la naturaleza y el autogobierno. En dichas sociedades no había, como ahora, una separación entre la vida y el trabajo, y se trabajaba según las necesidades.

Naredo [1997: 5] afirma que esas sociedades no estaban estructuradas por el trabajo y que la antropología trismo.

1 E ignorando que es un mundo griego apropiado por el eurocen- 
ofrece hoy abundantes materiales que muestran que en estas sociedades la noción de trabajo no tiene ni el soporte conceptual ni la incidencia social que tiene en la nuestra. En primer lugar, se observa que su lenguaje carece de un término que pueda identificarse con la noción actual de trabajo. No existe una distinción clara entre actividades que se suponen productivas y el resto. Por otra parte, las actividades directamente relacionadas con el aprovisionamiento y la subsistencia ocupaban en estas sociedades un tiempo muy inferior a la jornada laboral actual.

Shalins [1975] hace una contribución fundamental para desmitificar la economía actual, diciendo que, en el paleolítico, entre los grupos de cazadores y recolectores había una distribución del tiempo entre el trabajo y el ocio-descanso, que no otorgaba una prioridad al primero, puesto que lo que se buscaba era satisfacer las necesidades básicas. El trabajo no se hacía de manera constante ni su objetivo era acumular ganancias; sostiene que:

al igual que los australianos, los bosquimanos dedican al ocio o a actividades recreativas el tiempo que no ocupan en tareas de subsistencia (...) se detecta aquel ritmo característico del paleolítico de un día o dos en actividad y un día o dos inactivo, estos últimos pasados de manera intermitente en la aldea. Si bien la recolección de alimentos es la actividad productiva primaria. La mayoría del tiempo de que disponen estas gentes (cuatro a cinco días por semana) se emplea en otras actividades, tales como descansar dentro del poblado o visitar otras aldeas. Una mujer recolecta en un día comida suficiente para alimentar a su familia durante tres días, y el resto de su tiempo lo pasa en el poblado confeccionando adornos, visitando otros poblados o atendiendo a las visitas de otras aldeas ${ }^{2}$.

2 Es discutible considerar que la confección de adornos no es trabajo, sino una actividad doméstica. 
Cuando permanece en casa, los trabajos rutinarios de la cocina, tales como cocinar, descascarar frutos, juntar leña para hacer fuego, e ir a buscar agua, le insumen de una a tres horas de su tiempo. Este ritmo de trabajo ininterrumpido y descanso también ininterrumpido se mantiene a lo largo de todo el año. Los cazadores tienden a trabajar más frecuentemente que las mujeres, pero su plan de trabajo es desigual. No es raro que un hombre cace con avidez durante una semana y deje luego de cazar durante dos o tres. Como quiera que la caza es algo impredecible y está sujeta a un control mágico, los cazadores experimentan algunas veces una temporada de mala suerte y dejan de cazar durante un mes o más. Durante estos períodos, las visitas, los pasatiempos y, en especial, la práctica de las danzas, son las actividades primordiales de los hombres [Shalins, 1975].

En las sociedades cazadoras y recolectoras no había el afán de acumular riquezas o excedentes que se observa en la nuestra: las existencias de riquezas estaban en la naturaleza y no tenía sentido acumularlas, ni era posible acarrearlas. La acumulación empezó a tomar cuerpo en forma de trofeos (muy particularmente de esclavos) que acreditaban las hazañas militares, y con ello, el prestigio social de los antiguos jefes de bandas de caza. Surgió así el desprecio que el temperamento aristocrático otorga a las tareas rutinarias más comunes, tendentes a asegurar la intendencia diaria, que fueron quedando a cargo de las mujeres o los esclavos. Tras el largo paréntesis del neolítico, las sociedades con Estado acabaron afianzando y extendiendo la forma de proceder antes apuntada, tendente a segregar actividades y personas serviles [Naredo, 1997: 5]. 


\subsubsection{ARISTÓTELES EN LA ANTIGÜEDAD GRIEGA: VISIÓN REDUCCIONISTA DEL TRABAJO. DESPRECIO POR EL TRABAJO MANUAL}

En el mundo occidental antiguo, no existía la palabra trabajo (homogéneo, abstracto y asalariado). Había una original unidad entre vida y trabajo, entre el trabajo y todas las dimensiones de la vida [Applebaum, 1992: 167; Meda, 1996]. Esta unidad no fue restaurada en la historia de la civilización occidental, excepto posiblemente por las comunidades religiosas apartadas, los experimentos utópicos del siglo XIX en Estados Unidos de América o por el movimiento de los kibutz en Israel [Applebaum, 1992: 167$]^{3}$.

En los mitos griegos, como en el Viejo Testamento, Prometeo, y Adán y Eva, respectivamente, debido a sus pecados, la humanidad debía procurar su reproducción mediante el trabajo. Se estableció así la importancia y reconocimiento social del trabajo agrícola, el cual se convirtió en la base de los valores materiales y morales, así como la fuente de riqueza y poder. En la sociedad homérica, se encuentra algo inusual desde la mirada occidental actual: los nobles y aristócratas trabajaban con sus propias manos. Ulises retando a los pretendientes de Penélope a surcar tierras, construyendo su propia habitación y la balsa para regresar a casa. Lo mismo pasaba con Aquiles y Héctor, y con las deidades como Atenea y Hefesto. El trabajo era bien considerado y la ética del trabajo es expresada con gran fuerza poética y religiosa por Hesiodo. Este concepto y reflexiones en torno al trabajo estaban asociados a culturas de pequeña escala basadas en la familia, la religión, y en una autoridad social y política

3 Hay otra historia por hacer acerca del trabajo desde una visión no eurocéntrica, a partir de las prácticas de culturas no occidentales y no orientadas por la razón instrumental. Ver el apartado 3. 
descentralizada. Sin embargo, entre los siglos v y Iv a.C., con el desarrollo de ciudades-Estado centralizadas, el desarrollo de la división del trabajo, la especialización de los oficios y el extendido uso de la esclavitud, el concepto de trabajo varió significativamente [Applebaum, 1992: 579]. Y fueron los filósofos más notables, entre ellos Platón, Sócrates y Aristóteles, quienes legitimaron una visión negativa del trabajo, limitándolo a lo físico y mecánico hecho por esclavos, labradores, comerciantes y artesanos, con el objetivo de que la aristocracia se dedicara a la buena vida y a la política [Applebaum, 1992].

\section{Contexto histórico}

La polis griega de los siglos $\mathrm{v}$ y IV a.C., era una sociedad agraria en donde coexistían el trabajo libre, la esclavitud y la participación en la política (la cual, como se verá más adelante, no era considerada trabajo). Las dimensiones de la ciudad-estado eran reducidas en relación con las magnitudes actuales. Atenas ocupaba un territorio pequeño. Las clases sociales básicas estaban política y jurídicamente diferenciadas.

En la base de la pirámide social se encontraban los esclavos, aproximadamente un tercio de la población de Atenas. La esclavitud era una institución universal en el mundo antiguo y los esclavos no tenían derechos políticos. Es exagerado, un mito, creer que los ciudadanos de la ciudad-estado formaban una clase ociosa, dedicada exclusivamente a la política, pues una parte debía combinar la política con otras actividades, entre ellas el cultivo de la tierra, el comercio o la artesanía para garantizar su reproducción económica. El mito aludido corresponde a una visión idealizada de una clase ociosa. "Es totalmente falso imaginar que en una ciudad como Atenas el ciudadano-tipo fuera un hombre cuyas manos no se manchaban con el trabajo" [Sabine, 2012: 32]. La esclavitud estuvo 
asociada durante una época al endeudamiento, práctica que fue abolida por Solón; la esclavitud cobró importancia gracias a los prisioneros de guerra o la compra-venta de esclavos en los mercados, mayormente por ciudadanos comunes, y en menor medida, por el Estado. Los esclavos no tenían derechos políticos, pero en periodo de guerra debían integrar las fuerzas navales. Estaban presentes en un gran abanico de actividades económicas, entre ellas, agricultura, comercio, carpintería, manufactura y el trabajo doméstico ${ }^{4}$. También se encontraban en la vida estatal, desempeñándose como oficinistas, secretarios y trabajadores en prisiones. Un grupo especial de esclavos, unos trescientos arqueros escitianos, hacían labores policiacas. Los esclavos eran predominantes en la minería y el trabajo doméstico, que carecían de unidad de origen, pues cualquier persona podía convertirse en esclava debido a la guerra, la piratería y por transgredir la ley; algunos eran griegos, pero la mayor parte eran bárbaros (no griegos). Ciertos esclavos disfrutaban de una posición privilegiada, podían vivir aparte de sus amos o tener su propio negocio, esto, pagando una renta a sus propietarios. La situación de los esclavos domésticos dependía de la decisión de sus amos, pues algunos podían esperar la manumisión durante o después de la vida de su propietario o comprando su libertad con dinero conseguido trabajando como artesanos; otros trabajaban de manera miserable y dura en las minas de plata sin esperanza alguna de libertad. [Applebaum, 1992: 28-29].

El segundo segmento social correspondía a los extranjeros residentes o metecos, quienes se dedicaban al comercio, la artesanía y la industria, y tenían una condición de libres, pero como los esclavos, no tenían ciudadanía. Y en el tercero se encontraban los ciudadanos, que tenían derecho por nacimiento a participar en la vida política, ya

4 Es necesario también considerar el trabajo sexual. 
fuera en la asamblea de la ciudad o en diversos cargos públicos. Los ciudadanos eran quienes tenían tierra y ganado [Sabine, 2012: 13]. Los hombres libres desempeñaban labores exclusivas en los ámbitos de la justicia, la política y el ejército; compartían con los esclavos todas las demás ocupaciones, con excepción del trabajo en las minas y en el espacio doméstico [Applebaum, 1992: 29].

No se sabe cómo era la distribución de la población entre estas tres clases sociales; no obstante, se estima que en Ática había unos tres esclavos por cada persona libre, "dedicándose por término medio dos tercios de ellos a la agricultura, las minas y canteras, las artesanías o el transporte y el tercio restante a tareas domésticas" [Naredo, 1997: 36-37].

La segmentación de la población entre estas tres clases sociales era muy rígida, sobre todo en términos de movilidad social ascendente, es decir, era impensable que los esclavos fueran ciudadanos. Lo mismo podía decirse de los metecos o extranjeros.

\section{La separación entre trabajo y actividad política}

Los pensadores griegos reflexionaron de manera muy amplia respecto de la buena vida y el buen gobierno. Platón (427-347 a. C.) es reconocido como uno de los que estableció de manera amplia la división social del trabajo entre clases sociales, es decir, entre ricos y pobres, y la división del trabajo entre diversos tipos de trabajo. Según Anthony [2001] en "La República", Platón sostiene que una de las funciones del Estado es facilitar el intercambio de bienes y servicios entre los individuos. Los hombres desempeñan las tareas necesarias y su importancia social está relacionada con el valor del trabajo que efectuaban. Habría tres actividades esenciales para el Estado: la provisión de servicios necesarios, de protección y el gobierno. El primero es llevado a cabo por trabajadores, el segundo por 
los guardianes, y el tercero por filósofos y reyes. El sistema educativo platónico estaba diseñado para la formación de una clase guardiana. El trabajo, la producción de bienes y servicios no tenía ninguna importancia y tampoco la educación de los trabajadores. La distinción entre funciones sociales y sus valores asociados es más clara en "Las Leyes", texto en el que Platón readmite la legitimidad de la propiedad privada; al mismo tiempo, sostiene que los ciudadanos deben ser apartados de hacer actividades en la industria y en el comercio, de desarrollar una destreza artesanal o promover algún negocio. En este sentido, el filósofo recomendaba que las actividades comerciales deberían ser limitadas a los inmigrantes. La agricultura es la función especial de los esclavos; el comercio y la industria, de los hombres libres que no son ciudadanos, y todas las funciones políticas, son la prerrogativa de los ciudadanos. De este modo, Platón arriba a un modelo de Estado en el que la ciudadanía está francamente restringida a una clase de personas privilegiadas que pueden encargar sus negocios privados, es decir, el trabajo sórdido de ganarse la vida, a esclavos y extranjeros. Según Platón, las ventajas de la especialización en el trabajo se explicaban porque las aptitudes de los hombres difieren y porque sus habilidades mejoran al desempeñar labores para las cuales tienen aptitudes especiales.

Estas concepciones pueden ser evidenciadas, de manera general, gracias al pensamiento del filósofo griego Aristóteles (384-322 a. C.), quien sostenía que en la búsqueda del gobierno perfecto (el cual se orientaba a tratar de garantizar a la sociedad el mayor grado de felicidad, siendo esta inseparable de la virtud), los ciudadanos "se abstendrán cuidadosamente de ejercer toda profesión mecánica y de toda especulación mercantil, trabajos envilecidos y contrarios a la virtud. Tampoco se dedicarán a la agricultura, pues se necesita tener tiempo de sobra para adquirir la virtud y para ocuparse de la cosa pública" 
[Aristóteles, s/f: 63]. Destacaba su punto de vista al decir que "en un Estado bien constituido, los ciudadanos no deben ocuparse de las primeras necesidades de la vida" [Aristóteles, s/f: 39], porque sólo ellos están dotados de la capacidad intelectual para participar en la vida de la polis.

Es evidente una clara jerarquización de las actividades laborales de acuerdo con el nivel de inteligencia implicada, al cultivo o deformación del cuerpo y a la ubicación en la sociedad. Los que utilizan el intelecto (los dueños de la tierra) están en los niveles más altos, y los que usan la fuerza corporal, entre los más bajos. De esto se desprende una valoración de las actividades inversamente proporcional al esfuerzo físico involucrado: "Entre los oficios, los más elevados son aquellos en que interviene menos el azar; los más mecánicos los que desfiguran el cuerpo más que los demás; los más serviles los que más ocupan; los más degradados, en fin, los que requieren menos inteligencia y mérito" [Aristóteles, s/f: 18].

Este planteamiento está orientado a legitimar la reducida participación de la sociedad en la vida de la polis, pues es propia únicamente del señor (terrateniente), en tanto ciudadano, mientras que los sectores dominados no tienen esta condición y deben dedicarse al trabajo manual. En este sentido, Aristóteles sostiene que el señor no tiene que trabajar directamente, sólo debe saber mandar a los esclavos para poder dedicarse a la contemplación o a la política:

Saber emplear a los esclavos constituye la ciencia del señor, que lo es, no tanto porque posee esclavos, cuanto porque se sirve de ellos. Esta ciencia, en verdad, no es muy extensa ni tampoco muy elevada; consiste tan sólo en saber mandar lo que los esclavos deben saber hacer. Y así tan pronto como puede el señor ahorrarse este trabajo, cede su puesto a un mayordomo para consagrarse él a la vida [Aristóteles, s/f: 9]. 
Mientras tanto, es necesario que el señor sepa emplear a los que le obedecen "lo demás toca al esclavo; y entiendo por lo demás la fuerza necesaria para desempeñar todo el servicio doméstico" [Aristóteles, s/f: 57].

La participación en la vida política es la actividad de mayor reconocimiento en la polis. Por el contrario, las labores manuales son vistas con desprecio; entonces, las labores manuales serán cumplidas por trabajadores libres, esclavos o mujeres, pero ninguno podrá tener la calidad de ciudadano. Entre los trabajadores libres se encuentran los labradores, los artesanos, los comerciantes y los mercenarios, cada uno desempeña una actividad específica. Así, el pueblo se compone de:

cuatro clases principales: labradores, artesanos, mercenarios y comerciantes (...) una clase numerosa, la de los labradores, prepara las subsistencias para la sociedad; de otro, los artesanos forman otra clase dedicada a todas las artes sin las cuales la ciudad no podría existir y que son, unas absolutamente necesarias, otras de adorno y de las que nos procuran ciertos goces. Una tercera clase es la de los comerciantes, en otros términos, la de los que venden y compran en los grandes mercados y establecimientos; una cuarta clase se compone de mercenarios [Aristóteles, s/f: 169].

En la concepción aristotélica, los esclavos no sólo son aquellos que están en tal condición legal, como propiedad del amo, sino también todos los otros trabajadores libres que deben realizar alguna actividad física para satisfacer sus necesidades básicas. Así, el filósofo griego sostiene que:

las especies de esclavos son tan numerosas como lo son los diversos oficios; y podrían muy bien comprenderse en ellos los artesanos, que viven del trabajo de sus manos; y entre los artesanos deben incluirse también todos los obreros de las profesiones mecánicas (...) Pero ni el hombre 
virtuoso, ni el hombre de Estado, ni el buen ciudadano, tienen necesidad de saber todos estos trabajos, como los saben los hombres destinados a la obediencia, a no ser cuando de ello les resulte una utilidad personal [Aristóteles, s/f: 57].

\section{Y resalta:}

una constitución perfecta no admitiría nunca al artesano entre los ciudadanos. Si se quiere que el artesano sea también ciudadano, entonces la virtud del ciudadano, tal como la hemos definido, debe entenderse con relación, no a todos los hombres de la ciudad, ni aun a todos los que tienen solamente la cualidad de libre, sino tan sólo respecto de aquellos que no tienen que trabajar necesariamente para vivir. Trabajar para un individuo en las cosas indispensables de la vida es ser esclavo; trabajar para el público es ser obrero y mercenario [Aristóteles, s/f: 59].

En la vertiente de formar ciudadanos, la educación debía orientarse a enseñar cosas útiles a la juventud para impulsar las ocupaciones liberales y no las serviles; la juventud no debía recibir conocimientos que la convirtieran en artesana. Aristóteles sostiene que son:

ocupaciones propias de artesanos todas aquellas, pertenezcan al arte o a la ciencia, que son completamente inútiles para preparar el cuerpo, el alma o el espíritu de un hombre libre para los actos y la práctica de la virtud. También se da el mismo nombre a todos los oficios que pueden desfigurar el cuerpo y a todos los trabajos cuya recompensa consiste en un salario, porque unos y otros quitan al pensamiento toda actividad y toda elevación [Aristóteles, s/f: 116].

En suma, la clasificación social que Aristóteles propone responde a su visión de la vida en sociedad, para la 
cual las relaciones de mando y obediencia verticales son indispensables y útiles para la vida social, se establece de modo natural quienes mandan y quienes deben obedecer. Esta clasificación era hecha teniendo en consideración el trabajo y el sexo, de manera importante, y la edad, de modo secundario.

En la constitución republicana se pasa de ordinario, alternativamente, de la obediencia al ejercicio de la autoridad, porque en ella todos los miembros deben ser naturalmente iguales y semejantes en todo, lo cual no impide que se intente distinguir la posición diferente del jefe y del subordinado, mientras dure, valiéndose ya de un signo exterior, ya de ciertas denominaciones o distinciones honoríficas [Aristóteles, s/f: 19].

\section{El concepto reduccionista de trabajo}

Hay un consenso entre los estudiosos acerca del trabajo en la historia occidental antigua respecto a que había una concepción diferente a la de la colonialidad-modernidad; en aquella, el trabajo era considerado de manera despectiva, mientras que en ésta es vista de manera positiva [Applebaum, 1992; Anthony, 2001; Naredo, 1997; Meda, 1998; Innerarity, 1990]. Aristóteles, por ejemplo, sostenía que el trabajo manual era envilecedor e indigno de los ciudadanos, quienes debían participar en la vida pública de la polis. Sin embargo, es importante efectuar un análisis más fino para tratar de discernir qué entendían los griegos, especialmente Aristóteles, por trabajo. En el mundo griego había dos actividades diferenciadas entre sí: las labores manuales, orientadas a la producción de las necesidades básicas, y las que giraban en torno a la política.

No parece haber precisión respecto a lo que los griegos entendían por trabajo. De acuerdo con la concepción de Aristóteles, el ciudadano debía participar en la vida pública de la polis, para lo cual necesitaba dedicarse a 
la contemplación y a la virtud en libertad, sin esta sujeto a presiones para satisfacer sus necesidades básicas o ser parte de relaciones de dependencia (esclavitud, trabajo asalariado, artesanado). Por tanto, ¿cuál era el concepto de trabajo? La respuesta se orienta hacia un concepto restringido de trabajo, que incluía sólo las actividades manuales y era valorado negativamente.

Aristóteles considera como trabajo el trabajo manual, la actividad que por medio de la transformación de la naturaleza tiende a formar un producto determinado. El trabajo es considerado como un proceso de producción manual estrechamente vinculado a las exigencias de la naturaleza biológica del hombre. En ningún caso considera trabajo a la filosofía, la contemplación de la verdad [Innerarity, 1990]. El filósofo griego tenía una visión adversa del trabajo de los artesanos y de los esclavos por dos razones centrales: a) porque impedían la contemplación y la virtud que constituían el fin del hombre, b) porque la libertad era anulada o sometida. Así, aunque haya matices entre el trabajo efectuado por un obrero libre o un esclavo, ambos estaban incluidos bajo el mismo concepto peyorativo de trabajo; ambos eran considerados como banausía, como algo que va en detrimento de la dignidad humana [Innerarity, 1990]. Esto evidencia un concepto estrecho de trabajo vinculado únicamente a la actividad manual destinada a la satisfacción de las necesidades. La contemplación, reflexión y participación en la política escapan a la concepción aristotélica de trabajo, pues requieren tiempo de ocio.

En este sentido, para entender la separación que hace Aristóteles de actividades laborales y no laborales, es útil considerar los conceptos de poiesis (producción, making) y praxis (acción, doing) [Theocarakis, 2010: 2]. Según este autor, para Aristóteles, la vida era praxis, mientras que los esclavos o todos aquellos que trabajaban para otros, estaban involucrados en poiesis. Praxis significaba 
ser un ciudadano griego pleno, que filosofaba y participaba en la política. Un hombre que no participaba en los asuntos públicos era considerado un bueno para nada o un idiota. Un esclavo, era una "herramienta con espíritu" que debía ser mandado. Por tanto, trabajo será tomado siempre como poiesis, como producción, que nada tiene que ver con la praxis.

Para una mejor comprensión de este problema es importante comentar que "existen en Aristóteles dos modos distintos de actualización de las potencias: aquel movimiento que tiene límite (peras), en el que fin y proceso se distinguen, que es la kínesis, y por otro lado el movimiento en el cual el propio acto coincide con el fin (telos), que es la praxis. La poiesis es un tipo de kínesis, por tanto, se le puede aplicar todo lo que Aristóteles diga sobre ésta última (...) La praxis perfecta ${ }^{5}$, a diferencia de la kinesis, es aquella acción que es fin de sí misma, mientras que los movimientos tienen todos un límite, están subordinados al fin, distinto del movimiento mismo. Es decir, la relación entre acción y fin es lo que proporciona el criterio de distinción entre praxis y poiesis, según que la actividad posea el fin o tienda hacia él. Así, el movimiento sólo existe mientras no se da el fin, y en el momento en que éste se alcanza, cesa también la actividad: cuando se ha construido la casa ya no se edifica. En cambio, si se trata de la praxis, hay una coexistencia entre actividad y fin, de modo que en la misma acción se posee ya el fin: se piensa y se ha pensado,

5 "La praxis perfecta es la que el filósofo describe en el siguiente texto de la metafísica, por contraposición a la kínesis: "Puesto que de las acciones que tienen limite ninguna es fin, sino que todas están subordinadas al fin, por ejemplo, del adelgazar el fin es la delgadez, y las partes del cuerpo, mientras adelgazan están así en movimiento, no existiendo aquellas cosas a cuya consecución se ordena el movimiento, estos procesos no son una acción o al menos una acción perfecta (praxis teleta), puesto que no son un fin" [Innerarity, 1990: 71]. 
se ha logrado ya el fin al que tiende la actividad, sin que por ello ésta cese" [Theocarakis, 2010: 2].

De este modo, como sostiene Innerarity [1990: 71]: "no se encuentra en Aristóteles un concepto unitario y general de trabajo que abarque tanto la actividad manual como la intelectual, sino que únicamente es considerada como trabajo la actividad manual, que tiende a satisfacer las necesidades humanas". Por tanto, Aristóteles tiene un concepto reduccionista de trabajo, asociado a las actividades manuales y mecánicas.

En relación con las sociedades no clasistas, en Grecia y Roma, por diversas razones, la concepción del trabajo registra importantes cambios, siendo el más importante el creciente desprecio por el trabajo manual y/o dependiente, y la valoración del ocio en tanto elemento que permite la contemplación, la búsqueda de la buena vida y la participación en la vida pública. Dentro de esta concepción, el trabajo manual (destinado a producir bienes para la autosuficiencia, bienes y servicios para el intercambio, el comercio, y el trabajo esclavo) no permitía tanto el ocio como el desarrollo físico y espiritual. Se concebía, además, que lo relevante socialmente era ejercer una ciudadanía activa, es decir, participar en la vida de la polis. Por tales razones, se imponía y legitimaba una clasificación jerárquica del trabajo, que permitiera a las clases dominantes (vinculadas principalmente a la propiedad de la tierra) dedicarse con plenitud a la actividad política, como ciudadanos, dejando en manos de los sectores dominados (a quienes se negaba tal ciudadanía) los trabajos relacionados con la satisfacción de las necesidades esenciales por medio del esfuerzo físico. De este modo, se establecía una división jerárquica de la sociedad, entre los que mandaban y pensaban, y los que obedecían y con su trabajo físico producían lo necesario para vivir. Los primeros eran reconocidos socialmente, mientras que los segundos, por su carácter cercano a 
la naturaleza (su fuerza física) y su reducida capacidad intelectual, deliberativa, eran, por el contrario, despreciados. La mujer tampoco tenía derechos ciudadanos y se desenvolvía en el trabajo doméstico. Estaba sujeta al poder del marido:

Entre los bárbaros, la mujer y el esclavo están en una misma línea, y la razón es muy clara; la naturaleza no ha creado entre ellos un ser destinado a mandar, y realmente no cabe entre los mismos otra unión que la de esclavo con esclava, y los poetas no se engañan cuando dicen: Sí, el griego tiene derecho a mandar al bárbaro, puesto que la naturaleza ha querido que bárbaro y esclavo fuesen una misma cosa. Estas dos primeras asociaciones, la del señor y el esclavo, la del esposo y la mujer, son las bases de la familia [Aristóteles, s/f: 2].

Las responsabilidades de marido y mujer son distintas, ubicadas a partir de las relaciones de mando y obediencia que se establecían de manera natural entre ellos:

Del mismo modo, el valor y la prudencia difieren completamente de la mujer al hombre. Un hombre parecería cobarde si sólo tuviese el valor de una mujer valiente; y una mujer parecería charlatana si no mostrara otra reserva que la que muestra el hombre que sabe conducirse como es debido. Así también en la familia, las funciones del hombre y las de la mujer son muy opuestas, consistiendo el deber de aquél en adquirir, y el de ésta en conservar. La única virtud especial exclusiva del mando es la prudencia; todas las demás son igualmente propias de los que obedecen y de los que mandan. La prudencia no es virtud del súbdito; la virtud propia de éste es una justa confianza en su jefe [Aristóteles, s/f: 58]. 
El trabajo y la desigualdad entre las personas por diferencias de naturaleza (o la distribución de la población en el control del trabajo y en las relaciones de poder)

Para Aristóteles, los humanos no eran iguales, sino diferían entre sí según la parte (espiritual o corporal) que predominaba en cada uno de ellos. Lo natural era que el alma dominara al cuerpo, y la razón y la inteligencia orientaran las acciones sobre los deseos y las pasiones. Entonces, el humano dotado de capacidad de razonamiento debía mandar al humano que destacaba por su fuerza corporal y su falta de entendimiento. En la sociedad griega, los que debían mandar eran aquellos que poseían tierras y se dedicaban a la contemplación y a la política, y los que debían obedecer eran en quienes predominaba el cuerpo sobre el alma, carecían de discernimiento y destacaban por su fortaleza física. Eran estos últimos los que debían cumplir los trabajos vitales para la reproducción de la sociedad, sin contar con derechos de ciudadanía.

Así, Aristóteles sostiene que en el ser vivo el alma debe predominar sobre el cuerpo:

el ser vivo se compone de un alma y de un cuerpo, hechos naturalmente aquélla para mandar y éste para obedecer (...) Este predominio del alma es evidente en el hombre perfectamente sano de espíritu y de cuerpo, único que debemos examinar aquí. En los hombres corruptos, o dispuestos a serlo, el cuerpo parece dominar a veces como soberano sobre el alma, precisamente porque su desenvolvimiento irregular es completamente contrario a la naturaleza. Es preciso, repito, reconocer ante todo en el ser vivo la existencia de una autoridad semejante a la vez a la de un señor y a la de un magistrado; el alma manda al cuerpo como un dueño a su esclavo, y la razón manda al instinto como un magistrado, como un rey; porque, evidentemente, no puede negarse que 
no sea natural y bueno para el cuerpo el obedecer al alma, y para la parte sensible de nuestro ser el obedecer a la razón y a la parte inteligente [Aristóteles, s/f: 6].

El filósofo griego advierte que tales relaciones de mando-obediencia no deben ser modificadas para no ocasionar desórdenes o conflictos, sosteniendo que:

la igualdad o la dislocación del poder, que se muestra entre estos diversos elementos, sería igualmente funesta para todos ellos. Lo mismo sucede entre el hombre y los demás animales: los animales domesticados valen naturalmente más que los animales salvajes, siendo para ellos una gran ventaja, si se considera su propia seguridad, el estar sometidos al hombre. Por otra parte, la relación de los sexos es análoga; el uno es superior al otro; éste está hecho para mandar, aquél para obedecer [Aristóteles, s/f: 6].

Para Aristóteles, la relación mando-obediencia es un principio general que debe regir las relaciones sociales, pues sostiene que:

ésta es también la ley general que debe necesariamente regir entre los hombres. Cuando es un inferior a sus semejantes, tanto como lo son el cuerpo respecto del alma y el bruto respecto del hombre, y tal que es la condición de todos aquellos en quienes el empleo de las fuerzas corporales es el mejor y único partido que puede sacarse de su ser, se es esclavo por naturaleza. Estos hombres, así como los demás seres de que acabamos de hablar, no pueden hacer cosa mejor que someterse a la autoridad de un señor; porque es esclavo por naturaleza el que puede entregarse a otro; y lo que precisamente le obliga a hacerse de otro es el no poder llegar a comprender la razón sino cuando otro se la muestra, pero sin poseerla en sí mismo. Los demás animales no pueden ni aun comprender la razón, y obedecen 
ciegamente a sus impresiones. Por lo demás, la utilidad de los animales domesticados y la de los esclavos son poco más o menos del mismo género. Unos y otros nos ayudan con el auxilio de sus fuerzas corporales a satisfacer las necesidades de nuestra existencia. La naturaleza misma lo quiere así, puesto que hace los cuerpos de los hombres libres diferentes de los de los esclavos, dando a éstos el vigor necesario para las obras penosas de la sociedad, y haciendo, por lo contrario, a los primeros incapaces de doblar su erguido cuerpo para dedicarse a trabajos duros, y destinándolos solamente a las funciones de la vida civil, repartida para ellos entre las ocupaciones de la guerra y las de la paz [Aristóteles, s/f: 7].

Existía en Aristóteles una tensión ética respecto de si el hombre era esclavo por naturaleza o como resultado de relaciones de dominación. Se trata de una tensión ontológica del sujeto-esclavo, pues reconocer que la esclavitud existe por mera convención implica una fuerte objeción ética, ya que resulta insostenible afirmar que es justo sojuzgar y esclavizar a un hombre, ya que esclavo y amo no tienen diferencias de naturaleza, y que el dominio del segundo descansa en la fuerza. Así, afirmar que la esclavitud depende de una convención social y una acción voluntaria, significa que es susceptible de ser analizada e interpelada en términos éticos. Y aquí se desvanece todo intento de justificar y legitimar la existencia del ser-esclavo. El único modo de evadir el debate ético inherente a la dominación del hombre por el hombre, es convertir la cuestión de la esclavitud en un hecho de la naturaleza. De este modo, por oposición a la corriente que sostenía que la existencia de la esclavitud descansaba en una simple convención, Aristóteles elaboró un argumento lógico para legitimar la esclavitud, enunciando que por naturaleza existe lo dominante y lo dominado, y así como es mejor para el cuerpo ser gobernado por el alma, tam- 
bién es mejor para el esclavo ser mandado por un amo. El proceso de sometimiento en la relación amo-esclavo se debe, pues, a la existencia de una identidad-idem fundada en la teleología objetiva de la naturaleza. El esclavo es tal porque posee por naturaleza una disfunción cognitiva que consiste en carecer de la facultad deliberativa. Es la deconstrucción de la identidad social del esclavo lo que permite preservar su función económica. Al romper la ontología social de la dominación, es posible hacer descansar la identidad del esclavo en un núcleo duro, un idem ahistórico, que de modo similar al cogito cartesiano, puede erguirse como fundamento último del dominio señorial. Aparece así el ser-esclavo como un hombre que por su misma naturaleza ha sido cosificado, disminuido a instrumento, a un ser cuya existencia vital sólo existe como apéndice en relación con otro [Rodríguez Zoya, 2009: 11-12].

Aristóteles creía que el hombre podía alcanzar sus potencialidades como ser humano en tanto ciudadano de un Estado. El hombre es, por la ley de su naturaleza, parte de un Estado y no podría realizarse en sí mismo como hombre sin un orden político. Como los estados son variados, por tipos de ciudadanos también son diversos. En el Estado ideal, las cualidades de un buen hombre y de un buen ciudadano son idénticas. Como Platón, Aristóteles creía que sólo los ciudadanos debían tener sus propias tierras, y hacer que otros la trabajaran para estar libres y dedicarse a la guerra, la política y al arte del gobierno. Para Aristóteles, la música y la contemplación eran los más altos fines de un hombre cultivado, y el objetivo de la filosofía y de los más nobles propósitos sólo podrían ser alcanzados a través de la educación y el entrenamiento, lo que a su vez, sólo podría ser posible a través de la disponibilidad de tiempo de ocio [Applebaum, 1992: 69-70]. 
Balance: el trabajo en Aristóteles

y en la Grecia antigua

En esta sección se ha mostrado un concepto reduccionista y negativo del trabajo en la Grecia antigua gracias al análisis del pensamiento de Aristóteles, quien sostenía que la labor manual era signo de falta de autonomía, pues obligaba a los hombres a perseguir la satisfacción de las necesidades humanas y le impedía, por quitarles el tiempo de ocio, dedicarse a la contemplación, la filosofía y la política.

Todo trabajo manual, sometido a las necesidades de la vida o al dominio del amo afectaba la autonomía. Aristóteles rechazaba el trabajo manual y mecánico, razón por la que también rechazaba las labores comerciales e industriales, sosteniendo que debían ser llevadas a cabo por migrantes.

Es importante destacar, según Mossé [1980], que no era el trabajo en sí lo que creaba el sentimiento de desprecio, sino la relación de dependencia que se establecía entre el artesano y el usuario del producto fabricado. Construir su propia casa, su propio navío, hilar y tejer los vestidos de los habitantes de la casa, nada tenía de despreciable. Pero trabajar para otro a cambio de un salario, de la forma que fuera, era degradante. No había diferencia entre el artesano que vendía productos elaborados por él mismo y el hombre que alquilaba su fuerza de trabajo, pues ambos trabajaban para satisfacer las necesidades de otro; ambos, para subsistir, dependían de otra persona, por lo que a partir de ese momento ya no eran libres. Esta visión negativa del trabajo manual fue reforzada con la expansión de la esclavitud. El trabajo campesino fue valorado de manera diferente al artesanal durante un tiempo, en tanto que su trabajo permitía acercarse al ideal de la autarquía, situación que fue cambiando por el crecimiento de los intercambios mercantiles. ${ }^{6}$

${ }^{6}$ Una opinión semejante puede encontrarse en Ryken [2002: 65-66]. 
Según la concepción de Aristóteles, la desigualdad natural de los humanos establecía quién debía dedicarse a la filosofía, la contemplación y la política, y quién debía ocuparse del trabajo manual, principalmente mediante la esclavitud. Así, la distribución de las personas en las relaciones de poder, en este caso, en el control de la autoridad pública y del trabajo, se explicaba por una diferencia de capacidades intelectuales y raciocinio, en los que controlaban la autoridad pública y el trabajo, mientras que los dominados y explotados, excluidos del derecho de ciudadanía, destacaban por su fuerza física y sus bajas capacidades de raciocinio y argumentación.

No obstante, Mondolfo [1959: 9] sostiene que en la Grecia antigua no existió de manera generalizada la valoración negativa del trabajo. De acuerdo con la visión dominante, expuesta en este apartado, la Antigüedad clásica estaría caracterizada por una actitud general de menosprecio hacia el trabajo (banausía) y los trabajadores (bánausoi), sin tener en cuenta el hecho de que son ellos los que producen los bienes necesarios para la vida humana. "La intuición antigua de la vida (escribió De Ruggiero, La filosofía griega, II, página 304) se sintetiza en una negación del valor del trabajo, divino y humano, mental y físico. La conquista del concepto del trabajo será obra moderna". Mondolfo [1959: 9-10] dice que, en la primera mitad del siglo xx, dicha opinión fue revisada, siendo indicativo el juicio que W. Jaeger [1962] expresa en su capítulo sobre Hesíodo, en donde dice que al evidenciar con Hesíodo el heroísmo de la lucha tenaz y silenciosa de los trabajadores con la dura tierra y con los elementos, "ha sido Grecia la cuna de la humanidad que sitúa en lo más alto la estimación del trabajo". Diversos autore ${ }^{7}$ sostienen que en la Antigüedad griega se

7 Glotz, Le travail dans Lantiquité; Schuhl, Machinísme et philosophie; Farrington, Ciencia griega, El cerebro y la mano en la antigua Grecia, y Battaglia, Filosofía del lavoro. 
enfrentan dos conceptos opuestos de trabajo, y que el concepto negativo logra prevalecer sobre el positivo (que tenía anteriormente el predominio) sólo a partir del siglo IV a. C., y por la confluencia de todo un conjunto de factores: ya de carácter económico, como la intensificación del empleo de los esclavos y la consiguiente depresión de la situación social de todos los trabajadores; ya de carácter político, como las reacciones de castas aristocráticas — por ejemplo, en Tebas- y el predominio del militarismo - por ejemplo, en Esparta-, ya de carácter ideológico, debido especialmente al influjo de pensadores y escritores, como Platón, que al exaltar la vida contemplativa han producido — según la expresión de P. M. Schuhl—un verdadero blocage mental contra el trabajo y la técnica. Pero hay que destacar que la tradición contraria, que tiene en gran aprecio el trabajo, no sólo mantuvo en un primer tiempo, desde Hesíodo hasta Sócrates, el predominio en la opinión pública de los griegos - especialmente en las democracias industriales y comerciales, como Corinto y Atenas-, sino que conservó su poder sugestivo aun sucesivamente y en tal medida, que ni siquiera los representantes típicos de la orientación menospreciadora, como Jenofonte, Platón y Aristóteles, pudieron sustraerse a su influjo. El valor del trabajo se ve señalado en la tradición griega en tres aspectos: el económico, el moral, el intelectual.

\subsubsection{SAN AGUSTÍN Y SANTO TOMÁS DE AQUINO}

EN EL MEDIOEVO Y EL CRISTIANISMO: HACIA UNA

VALORACIÓN POSITIVA DEL TRABAJO MANUAL

Y EL RECONOCIMIENTO DEL TRABAJO INTELECTUAL

Este apartado tiene por finalidad analizar el concepto de trabajo en los periodos históricos denominados Antigüedad (v a.C.-v d.C) y medioevo (siglos v al xv), desarrollado desde el pensamiento cristiano, incluyendo a sus 
principales exponentes: san Agustín y santo Tomás de Aquino. Hay una vasta literatura según la cual el movimiento monástico y su ideología proveyeron las bases de la evaluación positiva del trabajo manual en la sociedad occidental [Mundford, 1967]. No obstante, se mantuvo la jerarquía del trabajo intelectual sobre el manual. Al mismo tiempo, se fortaleció la idea de la desigualdad natural de las personas como criterio básico para su distribución en las relaciones de poder.

En la cristiandad primitiva el trabajo era visto como un castigo por el pecado, pero también para servir en propósitos de caridad, salud del cuerpo y el alma, y para alejar los pensamientos diabólicos vinculados a la ociosidad. No obstante, el trabajo no tenía ningún valor en sí mismo. Así, el cristianismo hizo también suyo el desprecio por lo que hoy grosso modo denominamos trabajo. Se tomó como castigo fruto de una maldición bíblica y no como un objetivo ni individual ni socialmente deseable, máxime cuando se propugnaba el desapego de los bienes terrenales, presente en la Europa cristiana medieval. Por otra parte, tampoco existía en la Edad Media una visión unificada de las actividades que hoy llamamos productivas [Naredo, 1997].

No obstante, según Appeblaum [1992], la ideología judeocristiana introdujo un nuevo elemento al concepto de trabajo. Dios fue retratado como trabajador, ocupándose seis días a la semana y descansando el séptimo. ¿Qué podría mostrar con mayor claridad la divinidad del trabajo? Pero también fue asociado con el pecado de Adán, de modo que el hombre debía mantenerse con el sudor de su frente. También fue considerado honorable en oposición al pecado de la inactividad y pereza (san Pablo decía que el que no trabajara no comería). San Agustín y san Benito basaron el movimiento monástico en el principio y la moralidad del trabajo como un medio de combatir el pecado, y el trabajo como honorable a 
semejanza de Dios, maestro trabajador y arquitecto del mundo. En sus cartas y su propia vida, san Pablo ejerció una gran influencia en torno a la posición de los primeros cristianos frente al trabajo (puede considerársele como uno de los apóstoles más influyentes). Durante los años de prédica del Evangelio, san Pablo se proveía trabajando como tejedor de tiendas (tentmaker). Cuando estuvo con los corintios, se estableció con otros tejedores de tiendas. En Efeso, combinó la enseñanza con su trabajo, lo veía como algo que aseguraba la independencia personal y un medio que permitía ser caritativo con los necesitados. Aunque san Pablo como misionero tenía asegurada la alimentación y la vivienda, insistió en trabajar para no ser una carga en las pequeñas comunidades cristianas en las que predicaba. Una de sus expresiones favoritas era: "mi compañero trabajador" [Applebaum, 1992: 184]. San Pablo sostenía que la importancia del trabajo se relacionaba con el respeto a sí mismo y la independencia ${ }^{8}$. El hombre que trabajaba para satisfacer sus necesidades preservaba su independencia y libertad económica. Otro motivo para trabajar, destacado después por san Agustín y la Iglesia en el medioevo, fue la caridad [Applebaum, 1992: 184]. Se sostenía que era más bendecido dar que recibir, esto es, la idea de que uno podría cuidar de otros trabajando, y al mismo tiempo, la idea de trabajar por el bien de las almas, fueron parte de las enseñanzas de san Pablo. El trabajo se convierte en un servicio divino, los trabajadores son peones de Dios, y ellos serán recompensados por sus diligentes trabajos. [Applebaum, 1992: 185].

Según Georghegan, san Pablo estableció un alto valor para el trabajo manual. Una variedad de efectos benéficos provenía del trabajo: la independencia económica, el auto-

8 Su punto de vista respecto al trabajo se puede ver en "Actas" y "Tesalonicenses 2". 
rrespeto y una posición social honorable, tranquilidad de espíritu, ayuda a los necesitados y un premio sobrenatural. El trabajo se convirtió en una obligación de caridad, así como en una obligación natural. Al enseñar la dignidad inherente del individuo y la augusta obligación de su trabajo, los apóstoles dieron a sus trabajadores conversos una nueva apreciación de ellos mismos y un nuevo sentido de dignidad a su trabajo [Georghegan, 1945: 117-121, citado por Applebaum, 1992: 185]. Entre los escritos de los padres apostólicos (pequeño grupo de escritores que preservaron la enseñanza y tradición apostólicas, entre el tiempo de los apóstoles y la segunda centuria), Georghegan destaca tres aspectos relativos al trabajo: expiación del pecado, la necesidad de trabajar para la caridad, y la necesidad de combinar el trabajo manual con el intelectual, como hizo san Pablo, aunque se valorara más el trabajo intelectual [Georghegan, 1945, citado por Applebaum, 1992: 185].

\section{San Agustín}

San Agustín de Hipona (354-430 d. C.), tratando de resolver problemas organizativos de la Iglesia, al reflexionar acerca del trabajo, estableció que era obligatorio para los monjes, aunque debía alternarse con la oración y llevarlo a cabo solo para suministrar las necesidades básicas de los establecimientos eclesiásticos. Los padres de la iglesia debían dedicarse a la meditación de los asuntos divinos, desempeñando el trabajo intelectual que suponía la lectura y copiado en los monasterios [Mills, s/f].

San Agustín es considerado como la mayor autoridad del trabajo en la Iglesia de la Antigüedad. En su importante texto De opere monachorum (El trabajo de los monjes), destacó los beneficios del trabajo como una vía para la perfección moral. Para atender sus propias necesidades, el hombre debe involucrarse en la agricultura, comercio o industria, considerando que el beneficio eco- 
nómico no es un fin en sí mismo. El hombre no serviría a Mammon, es decir, no debería buscar la abundancia o avaricia material y debería reconocer que cuenta con la ayuda de Dios.

De opere monachorum fue escrito con el fin de argumentar por qué los monjes de Cartago debían trabajar con las manos, pues ellos sostenían que no tenían que hacerlo porque predicaban la palabra de Dios y debían vivir de los regalos de los feligreses. San Agustín se respaldó en el pensamiento de san Pablo para sostener la obligación del trabajo manual. Este apóstol había manifestado: "quien no quiera trabajar, que no coma", pero los monjes sostenían que el Evangelio los eximía del trabajo manual.

Afirmaba san Agustín en La ciudad de Dios que San Pablo había dado el ejemplo al trabajar manualmente:

(San Pablo) producía honrada y honestamente objetos útiles para los usos humanos, tales como son los servicios de los carpinteros, albañiles, sastres, agricultores y demás. Tales trabajos no los condena la decencia, sino el orgullo de quienes desean ser llamados honestos, sin querer serlo de verdad. No se sintió deshonrado el Apóstol por dedicarse a trabajos del campo o a cualquiera otra labor de artesanía [San Agustín, s/f: 9].

Los religiosos de Cartago se apoyaban en el Evangelio para no seguir el ejemplo de san Pablo. Al respecto, san Agustín sostenía que:

Los argumentos que aducen esos monjes que se niegan a trabajar ( ) Afirman ellos que, cuando el Apóstol dice: "quien no quiera trabajar, que no coma", no se refiere al trabajo físico, en el que se afanan campesinos y artesanos, ya que no puede contradecir al Evangelio en el que afirma el Señor [San Agustín, s/f: 1]. 
Los monjes interpretando el pensamiento de san Pablo decían: "el Señor nos manda que esperemos confiados nuestro vestido y alimento". Pero san Agustín se preguntaba: “¿Cómo podría el Apóstol sostener un pensamiento contrario al del Señor, exigiéndonos una actitud solícita por lo que hemos de comer, beber y vestir, mediante la imposición de trabajos, cuidados y oficios propios de los artesanos? Por lo tanto, cuando el Apóstol dice: 'quien no quiera trabajar, que no coma', hemos de referirlo, dicen ellos, al trabajo espiritual" [San Agustín, s/f: 1].

Y continuaba:

En definitiva, en esto se basan esos monjes para creer acatar la doctrina del Apóstol a la par que la del Evangelio: en que, por una parte, piensan que el Evangelio prohíbe preocuparse por las necesidades corporales y temporales de esta vida; y, por otra, en que el Apóstol, cuando dice: "quien no quiera trabajar, que no coma”, habla de la comida y del trabajo espirituales [San Agustín, s/f: 2].

Así, san Agustín sostenía que los monjes debían procurar su propio sustento para no ser una carga para los demás: "El Apóstol quiso que los siervos de Dios realicen trabajos manuales, por los que como fin han de recibir una gran recompensa espiritual; de ese modo, además, no necesitarán recibir de nadie el alimento y el vestido, puesto que se lo procurarán con su propio esfuerzo" [San Agustín, s/f: 2].

San Agustín planteó, además, que era posible llevar a cabo ambos tipos de trabajo, el manual e intelectual: "El cantar himnos santos es perfectamente compatible con el trabajo manual; es dulcificar el mismo trabajo con un ritmo de cadencia divina. ¿Acaso no vemos cómo los artesanos cantan con el corazón y la lengua motivos insulsos y hasta licenciosos sacados de las obras teatrales sin quitar la mano de su trabajo?" [San Agustín, s/f: 12]. Y añadía 
que esto era posible con una adecuada distribución del tiempo entre ambos quehaceres:

¿Cómo hubiese podido el Apóstol emplearse en trabajos manuales, si no hubiese fijado determinadas horas para predicar la palabra de Dios? (...) Este es el mejor gobierno: asignar a cada actividad un tiempo determinado y realizarlas en el orden fijado, con el fin de que no sea, a causa de la confusión y el desorden, el espíritu humano perturbado [San Agustín, s/f: 13].

Aunque san Agustín no creó una jerarquía en el trabajo, valoró como inherentemente superior el trabajo de difundir el Evangelio respecto de las labores manuales, que es la obligación de todos aquellos que no están involucrados en ocupaciones espirituales [Ovitt, 1986: 493]. Las enseñanzas agustinianas tuvieron un tremendo alcance en la legislación monástica de Occidente, pues establecieron de manera definitiva la obligatoriedad del trabajo, la excepción a tal deber para los inválidos, los ancianos y los enfermos, y los principios para combinar el trabajo manual con la contemplación y los ejercicios religiosos. Cada trabajador es instruido para trabajar con un ojo para servir a Dios más que a Mammon, a trabajar con confianza en la solicitud de Dios en él, para recordar que el fruto del trabajo es una evidencia del mandato divino, y estar satisfecho con el llamado de uno mismo, consciente del hecho de que aquellos con trabajo menos oneroso son más talentosos [Applebaum, 1992: 191].

\section{Santo Tomás de Aquino}

En este apartado se expone el pensamiento de santo Tomás de Aquino (1224-1274) en torno al trabajo en el siglo XIII, que produjo una nueva síntesis que superaba el concepto reduccionista establecido por Aristóteles al integrar en una 
única visión el trabajo intelectual y manual y, al mismo tiempo, modificó la visión cristiana del trabajo como castigo. Sin embargo, santo Tomás, por un lado, estableció la preeminencia del trabajo intelectual sobre el manual y, por otro, se basó en la concepción aristotélica respecto de la diferencia de naturaleza entre los hombres, y entre estos y las mujeres, idea que legitimaba una cierta distribución de las personas en las relaciones de poder, es decir, en el control del trabajo y de la autoridad pública colectiva. Por esta razón, continuó la formulación aristotélica de cómo se distribuyen las personas en las relaciones de mando y obediencia. Santo Tomás de Aquino, además, estableció la legitimidad de la remuneración del trabajo intelectual, considerando que este era una manifestación de la diversidad de oficios y modos de vida inherentes a la naturaleza humana, contribuyendo a que se reconociera la remuneración de los docentes, en tanto un tipo de trabajo intelectual.

Fue el mayor de los filósofos cristianos y creó una concepción del universo basado en la ley humana atada a la ley divina. Siguiendo a Aristóteles, santo Tomás concebía a la sociedad como un intercambio de servicios orientado a la vida buena. Los agricultores y artesanos suministraban los bienes materiales requeridos para vivir, los curas proveían la oración y el liderazgo moral, y los nobles la protección. La sociedad humana, según Aquino, era gobernada por los mismos principios de razón y orden que permeaban el universo entero. La participación en la ley eterna de criaturas racionales era la ley natural. La ley humana derivaba de la ley eterna y toda vocación/profesión de los gobernantes y de los trabajadores era necesaria para mantener el bien común. Concebía la sociedad cristiana como una comunidad interdependiente, un esquema racional de Dios, naturaleza y el hombre dentro de una autoridad civil que era resistente al cambio, y existió en un sistema cerrado de equilibrio estable y eterno [Applebaum, 1992: 581-582]. 
La época en la que santo Tomás de Aquino elaboró su concepción del trabajo se caracterizaba por la consolidación de la vida en París, con una creciente división del trabajo, la organización de los artesanos en gremios, y la creciente individuación de la gente de dicha ciudad. San Agustín enseñó Teología en la Universidad de París en el siglo XIII, época en la que la ciudad presentaba un importante dinamismo económico y cultural que inspiró una nueva visión del trabajo, misma que lo presentaba de manera positiva en términos de la humanización y salvación del hombre.

\section{El concepto de trabajo}

En el primer milenio del cristianismo, el trabajo manual era el único que se consideraba propiamente como trabajo, concepción dominante en toda la tradición monástica. No obstante, había dos miradas diferentes: la benedictina y la cisterciense. Para los benedictinos, la jornada de trabajo comprendía el trabajo manual, la oración y la lectio, considerada el momento fundamental de la oración. De la lectio se originaría, posteriormente, el estudio de las Sagradas Escrituras, actividad especializada que pasaría a denominarse trabajo intelectual, mismo que con Casiodoro, en el siglo VII, tendría una creciente importancia y llegaría a su auge en los siglos XI y XII. De manera contraria a lo establecido por la tradición antigua en relación al trabajo manual, los benedictinos planteaban que el trabajo intelectual superaba al manual, pues era más monástico $\mathrm{y}$ una mayor fuente de ascesis.

En la tradición monástica se consideraba que la vocación única del monje era la oración constante, actividad que podía ser interrumpida (si no podía evitarse) por el trabajo manual asociado con la necesidad material de subsistir como una condición impuesta a la naturaleza humana. Por tanto, el trabajo manual se justificaba por 
su vínculo con la subsistencia de los religiosos. En cambio, la orientación de Císter ${ }^{9}$ hacía hincapié en el trabajo manual, pues los primeros cistercienses entendían la vida monástica a partir del trabajo y la pobreza, lo que implicaba una ruptura con las prácticas del monacato de esa época que prefería la economía del regalo. De este modo, los cistercienses se inclinaban por la economía del beneficio, es decir, dedicarse a la producción agrícola y ganadera, buscando la autosuficiencia. En esta misma orientación, san Benito (480-547 d. C.), recuperando el legado de la primera era apostólica y de los padres del monacato, sostenía que los religiosos debían vivir de su propio trabajo en lugar de hacerlo a expensas de otro, y ayudando, además, a los pobres y peregrinos que vivían en los monasterios. San Benito consideraba que la vida en los monasterios debía basarse en la autarquía, es decir, en la autosuficiencia, y por tanto, en la satisfacción de las necesidades por medio del trabajo manual. Se tenía en cuenta, además, que el trabajo manual poseía un fuerte sentido de ascesis, pues el monje trabajaba como castigo por el pecado original, siguiendo la línea del Génesis, y el trabajo manual permitía controlar el cuerpo y someterlo

9 La orden cisterciense (ordo cisterciensis, en latín), conocida también como orden del Císter o santa orden del Císter (sacer ordo cisterciensis, en latín), es una orden monástica católica reformada, cuyo origen se remonta a la fundación de la abadía de Císter por Roberto de Molesmes, en 1098. Esta abadía se encuentra en donde se originó la antigua Cistercium romana, localidad próxima a Dijon (Francia). La orden cisterciense desempeñó un papel protagonista en la historia religiosa del siglo xII. Su influencia fue particularmente importante en el este del Elba, donde la orden hizo "progresar al mismo tiempo el cristianismo, la civilización y el desarrollo de las tierras". Como restauración de la regla benedictina inspirada en la reforma gregoriana, la orden cisterciense promueve el ascetismo y el rigor litúrgico dando importancia al trabajo manual. Además de la función social que ocupó hasta la Revolución francesa, la orden ejerció una influencia importante en los ámbitos intelectual o económico, así como en el ámbito de las artes y de la espiritualidad. Fuente: Cistercienses, disponible en <https://goo.gl/dNzmah>. 
al espíritu; la actividad manual ayudaba al equilibrio físico y síquico de la persona [Romero, 2001]. ${ }^{10}$

En este contexto tuvo lugar la elaboración teórica acerca del concepto de trabajo de santo Tomás, propuesta que se fundamentó desde lo teológico y ontológico ${ }^{11}$. Desde el punto de vista teológico, santo Tomás se basó en las Sagradas Escrituras considerando el trabajo del hombre como una imagen del acto creador de Dios. La obra del Creador, al que califica como summus artifex (el mayor artesano), fue un verdadero trabajo - un trabajo superior, una creación-, del cual Dios descansó para contemplarlo, el séptimo día. Dios fue el primer trabajador. Y al hombre, creado a su imagen y semejanza, le fue dado el trabajo antes de la caída; Dios lo había situado en el Paraíso para que lo trabajara y conservara. En un principio hubo un trabajo feliz, bendecido por Dios, al que después de la caída se le añadió la pena del esfuerzo, fatiga y sufrimiento, pero seguía conservando el fin querido por Dios.

Mediante una revisión de los textos cristianos sagrados, santo Tomás recuperó el valor positivo del trabajo manual al establecer que este había sido llevado a cabo por Dios para crear el mundo, y que la carga moral negativa derivada del pecado original fue posterior a la Creación. Al mismo tiempo, santo Tomás, al considerar el trabajo como un medio positivo para alcanzar la virtud y perfección, le atribuía también un valor de redención, pues señalaba que

10 Esta diferencia de enfoque respecto del trabajo de los monjes se ubica en un contexto, entre los siglos XII y XIII, en donde se produjo una excepcional valoración religiosa de la pobreza. Ciertos movimientos heréticos, como los humiliati, los valdenses y los cataros, o las beguinas y los begardos, veían en la pobreza el primero y más eficaz medio para realizar el ideal proclamado por Jesús y los apóstoles. Para encauzar aquellos movimientos el papa reconoció, a comienzos del siglo XIII, las dos órdenes de frailes mendicantes: dominicos y franciscanos. San Francisco redactó una regla inspirado en un pasaje del Evangelio según San Mateo: "Curad enfermos, limpiad leprosos (...) No os procuréis oro ni plata (...)" [Mircea Eliade, 1999].

11 Estas reflexiones están basadas en Peig [2007]. 
las penas del pecado (dolor, fatiga y muerte) no fueron eliminadas de la humanidad redimida sino asumidas por Cristo en la unidad de su divina persona y transformadas en los principales medios de su redención.

En la dimensión ontológica, la novedad del pensamiento de santo Tomás era que la razón de ser o naturaleza del trabajo en el hombre era lo que lo distinguía de sus predecesores y contemporáneos. El religioso discutió qué era el trabajo y cuál era su fin a partir de cuatro ejes: el trabajo como modo de obrar natural al hombre; el trabajo como obra conjunta de la razón y las manos; la diversificación del trabajo, y la obligatoriedad del trabajo.

Santo Tomás sostenía que el trabajo era connatural al hombre. Se preguntaba cuáles eran los fines que obligaban a los religiosos al trabajo manual, e identificó tres: evitar el ocio, dominar el cuerpo, y la búsqueda de sustento ( $a d$ otium tollendum, ad corpus domandum y ad quaerendum victum, respectivamente). Estableció que, para los dos primeros, el trabajo manual no era un precepto, pues con otras ocupaciones podían lograrse. En cuanto al tercero, señalaba que el trabajo manual parecía ser un precepto, ya que san Pablo decía "trabaja con tus propias manos, como te lo hemos ordenado" (operamini manibus vestris, sicut praecepimus vobis).

Sin embargo, el hombre tiene inclinación al trabajo por propia naturaleza, lo que es evidente, ya que en su disposición corporal muestra una "natural" inclinación al trabajar con las manos. Santo Tomás se basaba en $D e$ Animalibus, libro XIV, de Aristóteles, quién afirmaba que el hombre estaba dotado de razón y podría conseguir lo necesario para vivir, pues tenía manos aptas para diversas obras con las que podía ejecutar los planes de la razón (concepciones rationis) mediante diversas destrezas (artificiis). Siguiendo a Aristóteles, considera una prueba de la connaturalidad del trabajo en el hombre, el hecho de que la misma estructura del cuerpo humano parece ordenada 
al trabajo, ya que debe proveerse del sustento y disfrutar de los recursos de la creación con las obras (trabajo) de su inteligencia y de sus órganos (especialmente el de las manos).

Santo Tomás amplió estas reflexiones en sus obras Sobre el trabajo manual, Sentencias y Suma teológica, al comentar textos del Génesis. Señaló que, en su origen, el trabajo no era consecuencia del pecado, sino que formaba parte del plan inicial que Dios tenía para el hombre, ya que en principio (estado de inocencia), Dios creador había destinado al hombre para trabajar y custodiar el paraíso donde fue colocado. Dios había instituido el trabajo humano como afirmación y obra de una naturaleza vigorosa destinada a dominar. En Suma Teológica, santo Tomás señaló las características del trabajo humano en estado original: connatural a la estructura humana; gozoso y deleitable; ordenado a la felicidad y al bien del hombre; un ejercicio soberano del dominio del hombre sobre fuerzas de naturaleza inferior; libre de cualquier necesidad $\mathrm{u}$ obligación; el trabajo se diversifica como consecuencia de la libertad humana. Estas características permitían distinguir entre el trabajo en sí mismo y la pena impuesta al hombre después del pecado original, situación que no cambiaba, sin embargo, la naturaleza del trabajo, pues el pecado sólo había añadido una pena como medio de expiación y rehabilitación, y la nobleza y el fin del trabajo en el hombre, seguían siendo lo mismo.

Ya que se entiende por trabajo la obra conjunta de la razón y las manos o cualquier otro instrumento, debe abarcar cualquier actividad humana lícita. La mano puede ser considerada, según una expresión aristotélica, instrumento de instrumentos (organum organorum), porque es el instrumento apto para llevar a cabo los planes de la inteligencia, hecho que evidencia la estrecha relación y dependencia que hay entre mano y razón, idea base para revisar la naturaleza del trabajo manual. 
Si bien santo Tomás de Aquino tomó el concepto propuesto por Aristóteles de las manos como instrumento único, un instrumento adecuado para un fin determinado y creado para éste, su reflexión fue más allá, matizando y superando las observaciones de Aristóteles acerca de la relación razón-manos, al situarla en el contexto unitario de la persona. Recordemos que para Aristóteles la estructura del hombre estaba compuesta de un elemento racional y otro corpóreo (mandar y obedecer) con lo que se reproducía en el interior del hombre la relación existente entre señor y siervo, asignando al primero el sentido de dirigir con su capacidad racional el trabajo del segundo, mero ejecutor e instrumento.

Por el contrario, santo Tomás definió el trabajo como obra conjunta (unida) de la razón y las manos, basándose en la propia estructura del ser humano, según el principio de "el obrar sigue al ser" (operari sequitur ese). El hombre es un "compuesto sustancial de cuerpo orgánico y alma racional", tal hombre forma una unidad ya que no es solamente cuerpo ni solamente alma, sino el compuesto sustancial de ambos elementos. El cuerpo orgánico y el alma intelectiva se unen en el hombre como materia y forma sustancial del mismo. Aunque el alma — como forma sustancial—, es más perfecta que el cuerpo, son ambos elementos unidos sustancialmente los que constituyen a la persona. Si falta alguno de esos elementos, no puede darse propiamente el hombre o la persona humana. Esta concepción de la unidad de la persona, santo Tomás la extiende a su obrar y en consecuencia al trabajo, si el ser de la persona es uno, el obrar será también de uno, de aquí que en la actividad del hombre no pueden separarse la obra de la razón y la de las manos en el ámbito del facere o del arte.

De este modo, santo Tomás reformuló el pensamiento de Aristóteles, para quien el trabajo no tenía nobleza porque sólo el ocio hacía desarrollar la virtud y la actividad política; existía una separación en el interior del hombre 
entre la razón y la obra de las manos, de lo que se derivada una fragmentación entre hombre-intelecto y hombre-trabajador; el trabajo era igual a esclavitud y el trabajador manual sólo podía ser esclavo; el trabajo estaba en oposición con el hombre como tal, y la división del trabajo estaba determinada por las distintas categorías de esclavos.

Para los religiosos universitarios, este concepto aristotélico del trabajo manual y menospreciado, no permitía que su actividad intelectual fuera reconocida legítimamente como trabajo. La nueva interpretación formulada por santo Tomás otorgó, por tanto, a la labor no manual el estatus de trabajo, en un concepto amplio. Para esto, santo Tomás definió conceptualmente el trabajo dentro del contexto de la unidad de la persona en alma y cuerpo como obra conjunta de la razón y de las manos, considerando el trabajo como humanizado y humanizante. En cambio, Aristóteles consideraba el trabajo como puramente instrumental.

No obstante, santo Tomás, al considerar a la razón como el principio de toda acción y del trabajo, establece una distinción entre artes liberales y artes mecánicas, no lo hace en virtud de considerarlas como fruto de dos principios distintos e inconexos como ocurriría en un dualismo, sino en virtud de una jerarquía de valores o bienes que cada trabajo (arte) tiene. Así como el entendimiento y la voluntad son las facultades más nobles y superiores del hombre en relación con las demás, así el trabajo espiritual o intelectual lo son en relación con el manual, salvando siempre la nobleza de este último, porque también es una obra humana y humanizante.

Santo Tomás de Aquino estaba convencido de la superioridad del trabajo intelectual o contemplativo sobre la vida activa, por lo que se basó en la argumentación de Aristóteles: "la contemplación es lo mejor que hay en el hombre; tiene una duración más prolongada; es fuente de una dicha más elevada; asegura al hombre una libertad más completa; es un fin en sí misma; es un reposo 
supremo; es divina; distingue al hombre de los animales" [Jaccard, 1977: 162].

Otra preocupación de santo Tomás era que se reconociera la legitimidad del trabajo intelectual, pues afirmaba que respondía a la diversificación de oficios y maneras de vivir, que eran inherentes a la naturaleza humana. Señalaba que los trabajos destinados a solucionar las necesidades del hombre eran dignos de remuneración y medio lícito para vivir honestamente, aunque no estuvieran dirigidos directamente a la búsqueda de un sustento material, como los trabajos intelectuales, sociales y espirituales. De este modo, santo Tomás estableció una noción de trabajo en la que las tareas espirituales no sólo tenían utilidad social, sino que, en sí mismas, eran trabajo, y por eso, acreedoras de remuneración. Este punto de vista contribuyó de manera decisiva a modificar la visión dominante según la cual la enseñanza o docencia como oficio, de acuerdo con los principios evangélicos, debía desempeñarse de modo gratuito, pues santo Tomás planteó que la enseñanza tenía que reconocerse como actividad lícita y digna de ser remunerada [Peig, 2007].

\subsubsection{BALANCE DEL CONCEPTO DE TRABAJO} ANTES DE LA COLONIALIDAD-MODERNIDAD

Gracias a los aportes de san Agustín y santo Tomás de Aquino pueden apreciarse ciertos contrastes y continuidades en torno al concepto de trabajo en relación con Aristóteles. Santo Tomás de Aquino hizo una nueva teorización ampliando el concepto aristotélico reduccionista de trabajo que lo circunscribía al ámbito manual, incorporando la dimensión intelectual. De Aquino hizo una reconsideración positiva del trabajo manual al sostener, por medio de una revisión del Evangelio, que antes de la caída, del pecado original, la labor manual era valorada, 
pues Dios mismo había sido un trabajador manual, había creado el mundo a lo largo de un trabajo de siete días.

Al mismo tiempo, De Aquino se apartó de Aristóteles al hacer una nueva interpretación de la relación entre alma y cuerpo, sosteniendo que ambos constituían una unidad, y que las manos eran el mecanismo por medio del cual la mente se expresaba para crear. Esto, que lo diferenciaba de Aristóteles, quien consideraba que las manos eran un mero instrumento y que la vida estaba alojada en el alma, le permitió revalorar el esfuerzo manual y ampliar su concepto de trabajo, otorgándole un lugar al desempeño intelectual, el mismo que se iba convirtiendo en una actividad especializada de alto nivel de abstracción, pues se trataba del estudio e interpretación de la palabra de Dios y de los padres fundadores, obra que luego sería predicada y enseñada por los monjes, estableciéndose una suerte de división del trabajo dentro de los religiosos, ocupando el trabajo intelectual el lugar más elevado en términos jerárquicos. Tiempo después, en la época de la Reforma, Lutero cuestionó esta suerte de intermediación entre los creyentes y Dios, sosteniendo que cada quien debía leer e interpretar libremente la Biblia.

A medida que el cristianismo dejó de ser religión de los humildes y fue convirtiéndose en una religión de Estado, se dejó de resaltar la importancia del trabajo manual para darle mayor realce al trabajo intelectual, al mismo tiempo que el cristianismo se convirtió en el legitimador de un orden social despótico y explotador (el feudal), pues se argumentaba que las tres clases sociales básicas eran distribuidas de manera específica en las relaciones de poder: la nobleza daba protección y acceso a los recursos, el clero oraba por la salvación de las almas, y el campesinado era quien debía trabajar para sostener a los otros. Los campesinos eran vistos como personas bien dotadas físicamente para ejecutar trabajos manuales y con escasa capacidad intelectual [Jaccard, 1977]. 
Es en este aspecto en el que De Aquino presentaba una continuidad de pensamiento con Aristóteles, pues siguió creyendo que había una diferencia de naturaleza entre las personas que definía su participación en las relaciones de poder, específicamente en el control del trabajo y de las relaciones de mando-obediencia. Esta creencia de diferencias de naturaleza entre los humanos (y entre sexos) es parte de la epistemología y de la ontología occidentales y eurocéntricas, como se verá en el apartado A. 2, pues a partir del siglo XVI, la idea de la desigualdad natural entre hombres (y mujeres) fue reformulada a partir del constructo mental, denominado raza, que estableció una clasificación jerárquica de la población mundial a partir del color de la piel, de modo que los de piel blanca tendrían una participación dominante en las relaciones de mando-obediencia y en la distribución en las relaciones de poder, como lo ha sostenido Quijano [1990]. Sepúlveda, en la controversia de Valladolid, basó uno de sus argumentos respecto del derecho de la Corona española para someter a los "indios" en la condición de bárbaros que supuestamente tenían, en las ideas expuestas por Aristóteles, san Agustín y santo Tomás [Wallerstein, 2007; Manero, 2009; Ariza, 2005 y Álvarez-Cienfuegos, 2010].

Luego se refiere, sustentándose en La Política de Aristóteles, a las potestades que el hombre (padre, esposo, propietario y magistrado) tiene sobre los hijos, la esposa, los esclavos y los ciudadanos, en la línea de Aristóteles:

A esta ley están sometidos el hombre y los demás animales. Por eso las fieras se amansan y se sujetan al imperio del hombre. Por eso el varón impera sobre la mujer, el hombre adulto sobre el niño, el padre sobre sus hijos, es decir, los más poderosos y más perfectos sobre los más débiles o imperfectos. Esto mismo se verifica entre unos y otros hombres; habiendo unos que por naturaleza son señores, otros que por naturaleza son siervos [Sepúlveda, s/f: 293]. 
Y argumentaba Sepúlveda cómo debían establecerse las relaciones de mando-obediencia:

Los que exceden a los demás en prudencia é ingenio, aunque no en fuerzas corporales, estos son, por naturaleza, los señores; por el contrario, los tardíos y perezosos de entendimiento, aunque tengan fuerzas corporales para cumplir todas las obligaciones necesarias, son por naturaleza siervos, y es justo y ágil que lo sean, y aun lo vemos sancionado en la misma ley divina. Porque escrito está en el libro de los Proverbios: «El que es necio servirá al sabio.» Tales son las gentes bárbaras é inhumanas, ajenas á la vida civil y á las costumbres pacíficas. Y será siempre justo y conforme al derecho natural que tales gentes se sometan al imperio de príncipes y naciones más cultas y humanas, para que merced á sus virtudes y á la prudencia de sus leyes, depongan la barbarie y se reduzcan á vida más humana y al culto de la virtud [Sepúlveda, s/f: 294].

Así, Sepúlveda, se basó en san Agustín y en santo Tomás de Aquino para justificar el dominio y explotación de los "indios", afirmando que:

Téngase, pues, por cierto é inconcuso, puesto que lo afirman sapientísimos autores, que es justo y natural que los hombres prudentes, probos y humanos dominen sobre los que no lo son, y esta causa tuvieron los romanos para establecer su legítimo y justo imperio sobre muchas naciones, según dice San Agustín en varios lugares de su obra De Civitate $D e i$, los cuales cita y recoge Santo Tomás en su libro De Regimine Principum. Y siendo esto así, bien puedes comprender ¡oh Leopoldo! si es que conoces las costumbres y naturaleza de una y otra gente, que con perfecto derecho los españoles imperan sobre estos bárbaros del Nuevo Mundo é islas adyacentes, los cuales en prudencia, ingenio, virtud y humanidad son tan inferiores á los españoles como los niños á los adultos y las mujeres á los varones, habiendo 
entre ellos tanta diferencia como la que va de gentes fieras y crueles á gentes clementísimas, de los prodigiosamente intemperantes á los continentes y templados, y estoy por decir que de monos á hombres. [Sepúlveda, s/f: 306].

Por tanto, la principal contribución de la Edad Media a la historia de las actitudes hacia el trabajo fue dividirlo en dos grandes categorías: el sagrado y el secular. Las raíces de tal actitud estaban ya presentes en la clásica distinción social entre la gente libre y los esclavos. La Edad Media simplemente le dio a esta jerarquía un giro espiritual, y el resultado de esta división del trabajo entre sagrado y secular fue:

por supuesto, la reducción de los trabajadores ordinarios a ciudadanos espirituales de segunda clase (...) La diferencia entre los dos tipos de trabajo no era de grado, sino de categoría. (...) Dentro del monasterio o convento, los religiosos que buscaban la perfección se dedicaban mayormente (aunque no de manera exclusiva) a la contemplación, mientras afuera, en la familia, en el mercado, en el mar o en los mares, los otros mantenían girando las ruedas del trabajo del mundo, al costo de condenar sus almas a una vida espiritual subóptima [Ryken, 2002: 65-66].

En el mismo sentido, Ovitt [1987, citado por Kirkland, 2013: 19] ha mostrado que, aunque públicamente los monjes destacaban las virtudes del trabajo manual, a fines del siglo XII, las casas monacales encargaban de manera regular sus deberes laborales a trabajadores asalariados y conversos. Parecía existir en la educada élite de la sociedad medieval la creencia profunda de que el trabajo físico era una desagradable actividad plebeya, más apropiada para los campesinos ignorantes, con la excepción de los días santos, cuando podían dejar de trabajar arduamente para participar en la contemplación de lo divino. 
A pesar de la ambigüedad valorativa, es claro que con el medievo hay una apreciación positiva del trabajo manual, especialmente el artesanal. Le Goff [2003] sostiene que:

mucho antes que el protestantismo, como creía Max Weber, el cristianismo medieval favoreció el trabajo, hasta entonces despreciado como una consecuencia del pecado original y vinculado a la esclavitud. Toda una modernidad del trabajo se esboza a través de la glorificación de las herramientas que eran atributos de los santos, a través del prestigio de las corporaciones de oficios, a través de la consideración de utilidad de los trabajadores para el conjunto de la sociedad y a través de la idea de que el hombre en el trabajo puede ser un colaborador de la creación realizada por el primer gran trabajador, Dios.

Por tanto, las ideas de personajes como santo Tomás, de manera contradictoria, contribuyeron a recuperar el valor del trabajo manual. Y como sostiene Le Goff [2003: 781], la concepción del trabajo en tanto trabajo asalariado se elaboraría a partir del último tramo del siglo xv, y la identificación del trabajo con trabajo asalariado e industrialización, en el siglo XIX.

\subsection{EN LA COLONIALIDAD-MODERNIDAD: EL TRABAJO ASALARIADO PRODUCTIVO, ABSTRACTO Y HOMOGÉNEO, CREADOR DE RIQUEZA Y LA INVISIBILIZACIÓN DE LAS OTRAS FORMAS DE CONTROL DEL TRABAJO}

\subsubsection{LUTERO Y CALVINO: LA REVALORIZACIÓN}

Le Goff [2003] sostiene que la idea moderna de trabajo, es decir, la asociación del hombre primero, con el instrumento de trabajo, y luego con la máquina, se remonta a los siglos XIII y XV, periodo en el que fue tomando forma 
en la realidad material y social, y en la conciencia tanto de intelectuales como de los mismos trabajadores. En este sentido, la Edad Media es una de las grandes etapas creadoras de Occidente y del concepto moderno del trabajo. El vocablo trabajo, en su sentido moderno, no aparece hasta finales del siglo xv y no adquiere su significado actual hasta el siglo XIX. Existe una relación privilegiada entre la noción de trabajo y trabajo asalariado, que se convierte en una importante realidad económica y social (para ciertos lugares de Europa) a finales del siglo XV, pero también existe una relación característica entre trabajo e industrialización, que es un fenómeno del siglo XIX [Le Goff, 2003: 781].

Si en la Edad Media el trabajo era concebido de manera polar: por un lado, de modo negativo, como algo pesado, innoble, y por otro, de modo positivo, como algo honorable, ya que se trataba de una actividad creativa [Le Goff, 2003: 782], fue con el protestantismo cuando se produjo una revaloración definitiva del trabajo manual, y todo este proceso debe ser ubicado en un contexto más amplio, el del Renacimiento, esto es, del humanismo que impuso la valoración de la dignidad de vida de los trabajadores y apreció especialmente el trabajo manual. La revaloración del trabajo manual como parte del humanismo puede encontrarse en Utopía de Tomás Moro (1515). En Utopía, el lugar de la vida comunitaria, hay un reconocimiento del trabajo manual, se establece una jornada laboral de seis horas, para todos los adultos, con el fin de que cada persona tenga tiempo para liberar su mente [Ryken, 2002].

Los aportes de Lutero y Calvino fueron centrales en la revaloración del trabajo manual con respecto al trabajo intelectual y en el establecimiento de dos ideas centrales: la vocación o profesión, y el ahorro/frugalidad/condena de la ociosidad. En estos planteamientos no es difícil encontrar la influencia del ascetismo monacal o de los frailes mendicantes [Ryken, 2002]. 


\section{Lutero}

Martín Lutero (Eisleben, 1483-1546) fue un teólogo y fraile católico agustino, que como parte del impulso de la reforma protestante en el seno de la iglesia católica, hizo importantes contribuciones al concepto de trabajo.

La propuesta luterana asignó un nuevo sentido al trabajo humano, asimilándolo como el ejercicio de la profesión, la cual respondía al llamado único y particular de Dios a cada uno de los hombres ${ }^{12}$. De ahí que trabajar fuese para Lutero el deber moral más digno y noble con el que pudiese cumplir cualquiera de los mortales. El trabajo era per se una alabanza a Dios, quien le imprimía su carácter sagrado. El concepto luterano del ejercicio de "la tarea profesional en el mundo” [Weber, 1984: 91], fundó sin duda una nueva ética frente al trabajo, y marcó una ruptura definitiva con la concepción medieval de tradición católica, según la cual, el trabajo no trascendía más allá de su naturaleza material y servía al hombre como recordatorio de la desobediencia que le había valido su expulsión del Paraíso en el comienzo de los tiempos.

12 En la doctrina luterana, el término traducido como 'profesión', proviene del vocablo alemán Beruf, entendido como 'llamado', 'llamamiento'. También como 'vocación' o 'misión', que ya había sido referenciado por varios traductores de la Biblia anteriores a Lutero, quienes le asignaban un sentido religioso similar al que el monje reformador exaltó. Ejercer la profesión en el sentido luterano es atender al llamado que Dios le ha hecho a cada hombre en la manifestación del amor al prójimo, toda vez que quien ejerce la profesión, es decir, quien trabaja, lo hace en y para su comunidad. El significado de profesión en Lutero, dista pues, absolutamente, de su acepción profana de origen latino, según la cual, la profesión es "la actividad especializada y permanente de un hombre que, normalmente, constituye para él una fuente de ingresos y, por tanto, un fundamento económico seguro de su existencia" [Weber, 1984: 86]. La originalidad de la interpretación luterana del trabajo radica en el acento sobre la vinculación entre el compromiso de cumplir con la tarea profesional en el mundo como precepto moral por excelencia. Al respecto, véase Weber [1984: 85-105]. 
Al mismo tiempo, si bien el luteranismo hacía suyo el ascetismo de los monjes medievales, se apartaba de ellos al plantear que era viviendo en este mundo y no aislado de él, recluido en los monasterios, que debía efectuarse el trabajo para llegar a Dios. Como sostiene Jaccard [1977: 188]:

los reformadores estuvieron de acuerdo en lo esencial; el deber de los cristianos no estribaba en retirarse de este mundo, son en actuar en él, cada uno en su lugar, con fidelidad, perseverancia y caridad. De una manera completamente natural, el trabajo pasó ser, dentro de esta perspectiva, no solamente una obligación, sino un honor, un privilegio y un placer para quienes lo realizaban al servicio de Dios y del prójimo.

\section{LA REVALORACIÓN DEL TRABAJO MANUAL}

Uno de los más importantes aportes de Lutero respecto del concepto de trabajo, es la revaloración del trabajo manual, remontándose a los planteamientos bíblicos. Como lo reconoció en 1912 el moralista español Miguel de Unamuno, a Lutero pertenece el mérito de haber redescubierto la noción bíblica de la dignidad del trabajo. A los intelectuales de su tiempo, que a ejemplo de los antiguos, juzgaban vil y sórdida la condición de todo trabajador manual, a los señores y a los burgueses enriquecidos que se vanagloriaban de poder vivir en la ociosidad, el reformador les recuerda incansablemente la doctrina de las Escrituras respecto del deber y el beneficio del trabajo. Comentando el cuarto mandamiento en el sermón de las Buenas obras, en 1520, Lutero escribía:

Si preguntas si es una buena acción ejercer el propio oficio y realizar todo lo que es necesario para la vida y útil al bien común, y si ello agrada a Dios, verás que dicen que no y que 
restringen el campo de las buenas obras a las oraciones, los ayunos y las limosnas ordenados por la Iglesia. Creen que, aparte de ello, Dios no se preocupa de lo que hacemos. Reducen y empequeñecen el campo en el cual somos llamados a servir a Dios. Pero todo lo que se puede decir y hacer bajo la inspiración de la fe es un servicio prestado a Dios (...) Por la fe, toda distinción entre las obras, sean grandes o pequeñas, cortas o largas, numerosas o insignificantes, desaparece. Porque las obras no son agradables a Dios en sí mismas, sino a causa de la fe que las inspira [Jaccard: 1977: 188].

\section{LA VOCACIÓN}

Un segundo aporte fundamental de Lutero está relacionado con el concepto de vocación, pues extendió este mandamiento a todo hombre y no sólo a quienes tenían una vida eclesiástica. De este modo, si en la Edad Media sólo se veía en la ley del trabajo un mandamiento general dado a la posteridad de Adán, y al cual ciertas categorías de hombres podían sustraerse, Lutero hizo una regla para todos: cada hombre, sin excepción, es llamado por Dios a llevar a cabo una tarea personal. La universalidad de las vocaciones establece en la sociedad civil la igualdad fundamental de los hombres ante Dios. Automáticamente, esta concepción restauró el crédito de las clases inferiores de la sociedad, y los más humildes oficios cobraron una nueva dignidad. En su llamamiento, de 1520, "A la nobleza alemana", Lutero dijo:

Cada uno tiene en la comunidad su tarea particular: zapatero, artesano, campesino. De la misma manera que todos los miembros del cuerpo funcionan los unos para los otros, igualmente los cargos particulares, las vocaciones individuales sirven al bien general y no tienen otra finalidad que el cuerpo y el alma de la comunidad entera [Jaccard, 1977: 190]. 
Para Lutero, Dios no es más que una actividad esencial que debe alcanzarse en todo lo que se hace, en cada cosa y en cada persona. La vida es una ininterrumpida aparición de Dios al hombre; lo divino está combinado con lo profano. Por tanto, si toda actividad de todo tipo es divina, no hay bases para establecer una distinción entre el trabajo de los clérigos en "trabajo de Dios" y el trabajo cotidiano de los artesanos, comerciantes y campesinos. De este modo, el principio teológico de justificación por fe negando el valor a los "buenos trabajos" permite que la energía humana se oriente por entero al mundo material. El rechazo de toda autoridad religiosa emancipa la vida económica, dejándola enteramente a sí misma y a sus propias leyes. Con Lutero, profesión, vocación y llamado se convierten en sinónimos [Applebaum: 1992]. Tilgher concluye que: "Lutero colocó una corona sobre la frente sudorosa del trabajo. Con sus manos el trabajo adquiere una dignidad religiosa. La puerta que nos condujo a la modernidad fue en su tiempo definitivamente abierta" [1930: 50].

El concepto luterano de calling significa que debemos trabajar en lo que Dios nos ha encomendado y que debemos seguir. El calling es un mensaje de aceptación y acción en que cada hombre no está ocioso, sino que trabaja para su propia satisfacción. También es un mensaje de individualismo y, al mismo tiempo, de que gracias al trabajo individual, cada quien defiende el orden social existente.

Una palabra alemana, empleada en un sentido nuevo por Lutero, expresa su concepción del trabajo, del oficio y de la vocación: Beruf, que los puritanos ingleses traducirán como calling. Este término tomará en los países protestantes una significación y un alcance que no tenía la palabra tradicional vocación, cuyo sentido había limitado la Edad Media, aplicándola solamente a las funciones eclesiásticas. Beruf evoca a la vez el llamamiento de Dios, la tarea impuesta, el oficio elegido y la condición general del hombre [Jaccard, 1977: 190]. 
El concepto luterano de calling rechazó el doble estándar de la iglesia católica de vocaciones superiores e inferiores. También cambió el concepto de vocación o trabajo proveniente de la insistencia católica en la calidad penal, sufriente del trabajo, especialmente del manual, hacia el aspecto positivo y disfrutable del trabajo [Applebaum: 1992].

Así, Tilgher [1930: 47] sostiene que: "el Protestantismo es la fuerza movilizadora en la profunda revolución espiritual que estableció el trabajo en la mente moderna como la base y la clave de la vida, y en este sentido la primera voz del Protestantismo es Lutero". Para Lutero, al igual que para los pensadores medievales y monásticos, el trabajo era, al mismo tiempo, una forma de penuria, la base de la caridad y una defensa contra la ociosidad. Sin embargo, Lutero planteó una ruptura con el pensamiento monástico y la vida contemplativa, pues consideraba que los monjes vivían de manera egoísta, abdicando sus responsabilidades con el mundo como un todo. Por tanto, la idea de trabajo de Lutero resultó en una extensión universal, de manera que el trabajo se convirtió en la base universal de la sociedad y el objetivo de las diferentes clases sociales.

De este modo, Lutero, a diferencia de la teoría social de la cristiandad católica y romana, negaba la existencia de una jerarquía espiritual. La filosofía de santo Tomás de Aquino, como la de Aristóteles, a quien santo Tomás destacó, establecía una distinción entre trabajo mental y físico, entre ocupaciones liberales y serviles. Tanto Aristóteles como santo Tomás glorificaron el tipo de vida intelectual y contemplativo, y asumieron que el trabajo cotidiano fuera efectuado por seres inferiores. Es significativo que Lutero usara imágenes como un campesino con su carreta y arado, un zapatero con sus pieles y lezna, y que viera la oración de trabajo inscrita: "en la frente y rostro que sudan con el trabajo duro". Sudor, arado, brazos y trabajo esforzado son términos asociados con el trabajo manual [Applebaum, 1992: 324]. 


\section{Calvino}

Las contribuciones centrales de Juan Calvino (1509-1564) al concepto de trabajo, son el haber hecho de este, en la perspectiva bíblica desarrollada por Lutero, la base de una ética social en la vida de los cristianos: la idea de la predestinación y la frugalidad, el ahorro y la condena al ocio. Al mismo tiempo, Calvino agregó elementos doctrinales a la reforma iniciada por Lutero, que incluían, entre otros, el puritanismo, el acercamiento directo con Dios mediante la vida ascética que acrisola el espíritu, y el trabajo sistemático destinado a la glorificación de Dios. Calvino introdujo en la doctrina una condición adicional que actuaría como blindaje, en tanto la protegía de cualquier arremetida de la curiosidad humana. Esta especie de clausura ideológica se logró mediante el dogma implacable de la predestinación; cualquier mortal que se atreviese a cuestionarla, no sólo correría el riesgo de caer en la herejía, peor aún, demostraría sin lugar a dudas su predestinación a la condena eterna. La sola inquietud ya era muestra indiscutible de tal tragedia espiritual y humana. Era mejor, entonces, permanecer ocupado, muy ocupado, trabajando y glorificando a Dios, para que los malos pensamientos no tuviesen cabida en la conciencia [Weber, 1984, 130]. En la propuesta calvinista, el aprovechamiento riguroso y sistemático de cada segundo del tiempo en la vida de un ser humano determinaría si ese mortal sería víctima o beneficiario del dogma de la predestinación. El mecanismo excelso y efectivo que acercaría el espíritu del hombre a la grandeza divina sería entonces, según Calvino, el trabajo. En otras palabras, cada segundo trabajado al máximo, cada ganancia obtenida y aprovechada frugalmente por quien la obtiene, era una muestra indudable de su predestinación a la gloria divina. Lo contrario: el ocio, la pereza, y por supuesto la pobreza y la desgracia, serían, a la luz de la doctrina calvinista, una prueba irrefutable de 
su predestinación a la condena eterna [Weber, 1984: 130131]. Las ideas calvinistas proponían, como lo describe Hopenhayn [1988: 92]: "la racionalización sistemática de la vida moral”. Racionalización que trascendía a todas las esferas de la vida humana y determinaba no sólo su vida interior, sino también la vida social, y especialmente, las relaciones económicas con sus congéneres, pues la predestinación eximía del ejercicio de la caridad frente a los miserables, a aquel que acrecentaba sus riquezas, señal indefectible de la predilección divina. La doctrina calvinista legitimaba la acumulación individual como retribución justa al buen trabajo, que a su vez constituía una clara manifestación de la gracia otorgada por Dios. Es ahí donde, según señala Hopenhayn, Weber encuentra la legitimación de lo que el sociólogo alemán llama el espíritu del capitalismo, determinante fundamental en la dinámica de la economía occidental a la cual pertenece, como categoría excelsa, el trabajo industrial asalariado. La insistencia calvinista en cuanto a la racionalización de la vida tampoco es suficiente para explicar la gran transformación de Occidente, y con esta, la aparición de las instituciones que configurarían un nuevo orden social, político, económico e industrial; no obstante, aporta algunas luces para asomarse a la comprensión de las ideas que posteriormente, en el siglo XIX, se instalaron formalmente en la conciencia del hombre europeo que creció bajo su influjo, de modo particular en los ingleses, quienes bien puede decirse, inauguraron el proceso de industrialización [Garcés, 2008: 125].

\section{LA ÉTICA SOCIAL BASADA EN EL TRABAJO}

Para Calvino, el mandamiento del trabajo tiene una autoridad particular debido a que, al promulgarlo, el Creador se puso a sí mismo como ejemplo. La ociosidad y la pereza, como la blasfemia, son ofensas a la majestad divina, por 
eso son malditas de Dios. Por otra parte, el reformador insiste en que Cristo, como su padre celestial, permanece siempre activo. Así, Calvino predica doctrinas de práctica, un evangelio que no debe permanecer ocioso en nosotros, sino que debe fructificar, no sólo en obras de piedad, sino también en trabajo. Varias veces pregunta: “¿Creéis que Dios se ha complacido jamás en la ociosidad de los hombres? Es seguro que no" Jaccard [1977: 189]. Comentando el precepto de Pablo acerca del derecho a comer, negado a los que no quieren trabajar, Calvino observa que la sanción del apóstol se aplica solamente a los que tienen "fuerzas y medios para ganarse la vida". Por otra parte, precisa que no debe clasificarse entre los ociosos a los consejeros, los maestros de escuela, los mercaderes, los empresarios y administradores públicos o privados, cuando son íntegros, porque también ellos "ayudan y benefician con su trabajo a la sociedad de los hombres”. Calvino se extendió también en el comentario al capítulo del libro del Éxodo, en donde se trata la vocación del artesano Besalel, en él encuentra la prueba del origen divino de las artes y los oficios. Éstos, dice, deben ser infinitamente respetados, porque "todos vienen de Dios" y son "como invenciones divinas". En efecto, el espíritu de Dios no aparece solamente en los dones espirituales que son el fruto de la regeneración, sino también en todas las ciencias que se refieren a la práctica de la vida de todos los días". A la "solicitud divina" debemos "todas las comodidades de las cuales nos servimos”, y, más aún, la poesía, las artes y las ciencias, es decir, "todo lo que contribuye a favorecer y proteger la vida” [Jaccard, 1997: 189].

Será Calvino, sin embargo, quien dará a la doctrina bíblica del trabajo toda su importancia en el pensamiento y en la vida de los cristianos. Calvino hace del trabajo la base de una ética social que ejercerá una acción profunda y duradera en Francia (por lo menos hasta la revocación del edicto de Nantes), en Suiza, los Países Bajos, Inglate- 
rra, Escocia y Estados Unidos de América [Jaccard, 1977: 190-191]. Fue Calvino quien dio a esta rehabilitación de los oficios toda su amplitud y justificación. Lutero, próximo todavía a la Edad Media, consideraba la vocación como un estado en el cual el hombre debía trabajar al servicio de Dios. Calvino dio a esta concepción no solamente un alcance más amplio, sino un valor positivo, un sentido activo, o como se dice hoy, un dinamismo nuevo, al enseñar que el hombre debe servir por medio de su vocación la cual es no tanto un estado como una fuerza activa, no tanto un privilegio como un deber, no tanto una condición heredada o adquirida como una obligación de ejercitar, cada vez más, talentos, dones y posibilidades. Todo esto, Calvino lo dice en numerosos pasajes de sus escritos y discursos, pero nunca con tanta claridad como en la admirable página con la cual termina, en 1539, la primera edición francesa de la Institución cristiana. He aquí sus últimas líneas, en las cuales toda la obra halla realmente su meta y su fin:

(...) Si no adoptamos nuestra vocación como una regla perpetua, no habrá correspondencia entre las partes de nuestra Vida. Por eso, quien habrá dirigido su vida hacia esta finalidad la habrá ordenado bien. De ello nos llegará un singular consuelo: que no habrá obra tan vil ni tan sórdida que no reluzca ante Dios y no sea sumamente valiosa, siempre que en ella sirvamos a nuestra vocación.

La importancia histórica de la doctrina calvinista de las vocaciones es enorme, constituyó la fuerza de los hugonotes y puritanos de los siglos XVI y XVII que hicieron florecer la agricultura, la industria, el comercio y las artes en Francia, Holanda e Inglaterra, y más tarde, después del destierro, en Alemania, así como en las colonias de América. Campesinos o gentiles hombres-granjeros, como Olivier de Serres; tejedores, impresores o artesanos 
de arte como Bernard Palissy; magistrados o soldados, como Sully o Caligny, mercaderes o navegantes, todos ellos vivieron realmente en el sentimiento de su vocación [Applebaum, 1992].

Con el calvinismo emergió una nueva actitud al trabajo [Tilgher, 1930: 58]. Todos los hombres, incluidos los ricos, tenían que trabajar, debido a que el trabajo es la voluntad de Dios. Pero ellos no deben ambicionar los frutos de su trabajo. Con este tipo de credo surge un nuevo tipo de hombre - de gran voluntad, activo, austero y trabajador-. El ocio, la lujuria y la prodigalidad — todo aquello que suaviza el espíritu- es eludido. El disgusto por el trabajo es una señal de que uno no está destinado a la salvación. El trabajo intermitente, ocasional, no ayuda. Debe ser metódico, disciplinado, racional, uniforme y especializado. Seleccionar una vocación (calling) y seguirla con toda consciencia es una obligación religiosa. El puritanismo, que se desarrolló desde el calvinismo, va mucho más allá, enseña que es el deber personal extraer la mayor ganancia posible de su trabajo. El éxito, que es probado con la obtención de ganancia, es la indicación cierta de que la profesión escogida es del agrado de Dios. El puritanismo, por lo tanto, abre para cada profesión la perspectiva del beneficio, y justifica y permite la conversión del esfuerzo en riqueza, y ésta es reconciliada con una buena consciencia, y el deseo de ser pobre es un mal servicio a la gloria de Dios.

\section{LA PREDESTINACIÓN}

Juan Calvino sostenía que Dios ya había decidido quién debía ser bendecido después de su muerte, aun antes de nacer. La mayoría de las personas nacía en un estado de pecado y no era apta, a pesar de sus acciones, de salvarse de la condena y el infierno. Sin embargo, unas cuantas, mediante la gracia divina, estaban predestinadas a la vida 
eterna y la bendición ${ }^{13}$. Los calvinistas eliminaron a los sacerdotes y la jerarquía de la relación entre el creyente y Dios. El creyente se colocaba de pie, solo, frente a Dios, sin que los intermediarios pudieran interferir con lo que ya ha sido predestinado. Esto revela el tremendo énfasis en el individualismo en el calvinismo ${ }^{14}$ [Applebaum, 1992].

Para los católicos, el buen trabajo y las buenas acciones podrían conducir a la salvación. Pero para los calvinistas, desde que la bendición divina ha sido otorgada por adelantado, las buenas acciones no podrían cambiar el destino. Sin embargo, quienes querían convencerse a sí mismos o a los demás de su estado de gracia debían hacer buenos trabajos y dedicarlos a su vocación. Los buenos trabajos no eran un medio para salvarse, sino para asegurar la salvación ${ }^{15}$ [Applebaum, 1992].

A diferencia de los católicos, los calvinistas podrían no ser perdonados por caídas ocasionales, que más bien eran señal de que la persona no era una de las elegidas. En particular, la aversión al trabajo era un indicio de no haber sido elegido. La autodisciplina era lo más importante si se quería estar seguro de que poder ser salvado. El trabajo no debería ser, en ningún momento, descuidado o inconsistente, sino metódico, disciplinado, racional y uniforme ${ }^{16}$ [Applebaum, 1992].

Para los creyentes, el trabajo no tenía el objetivo de ganarse la vida, sino de glorificar a Dios y demostrar el

13 Para este comentario, Applebaum se sustenta en Max Weber, The Protestant Ethic and the Spirit of Capitalism, translated by Talcott Parsons, 2nd edition, London, George Allen \& Unwin, 1930, pp. 99-100.

14 Para este comentario, Applebaum se basa en Kemper Fullerton, "Calvinism and Capitalism: An Explanation of the Weber Thesis", in Robert W. Green (ed.), Protestantism, Capitalism and Social Science: The Weber Thesis Controversy, Lexington, D. C. Heath and Co, 1973, p. 17.

15 Op. cit.: 100-114 y Anthony Giddens, Introduction to Weber, p. 5. ((falta completar la referencia))

16 Para este comentario, Applebaum se basa en Adriano Tilgher, Work: What it has Meant to Men Through the Ages, translated by Dorothy Canfield Fisher, London, George G. Harrap, 1931, pp. 59-60. 
estado de gracia personal. No importaba cuando dinero podía tener uno, pues se debía continuar trabajando por más. El trabajo duro servía a Dios y desperdiciar el tiempo era, por tanto, el mayor de los pecados capitales. El trabajo tenía no sólo un valor moral, sino también un valor de estatus. Aun cuando carecían de una ética del trabajo y no creían en su virtud, para los protestantes era necesario trabajar tan duro para ser respetados en la comunidad y persuadir a los demás de que estaban entre los elegidos por Dios ${ }^{17}$ [Applebaum, 1992].

Calvino predicaba su teoría de la predestinación, lo que significa que sólo un número reducido de personas había sido elegido previamente por Dios para ir al Paraíso, y nada que se pudiera hacer en este mundo, sin importar su mérito, podría cambiar el destino predestinado. El esfuerzo humano, las instituciones sociales y el mundo de la cultura eran irrelevantes para la salvación, y podrían ser dañinos, ya que distraen al hombre del verdadero propósito de su existencia, que no era la salvación personal, sino la glorificación de Dios, algo que debía ser buscado mediante la acción y no del trabajo. Los buenos trabajos no eran una manera de conseguir la salvación, pero eran indispensables como una prueba de que la salvación había sido alcanzada.

El calvinismo predicaba contra el lujo y la ostentación, y enseñó a sus seguidores la modestia económica. Insistió en las virtudes de la industria, el ahorro y la frugalidad, y se opuso a la mendicidad. El calvinismo fue engendrado para liberar las energías económicas, lo que fue soldado

17 Para este comentario, Applebaum se sustenta en Max Weber, The Protestant Ethic and the Spirit of Capitalism, translated by Talcott Parsons, 2nd edition, London, George Allen \& Unwin, 1930, p. 157. 
en una disciplina para la ascendiente clase media. "Calvino hizo por la burguesía del seiscientos lo que lo Marx hizo por el proletariado de los novecientos" [Tawney, 1947: 9899, citado por Applebaum: 1992].

Para el calvinismo, la ociosidad era el vicio más peligroso. En este punto, luteranos y calvinistas estaban de acuerdo en el espíritu anti Mammon, el énfasis en la modestia y la moderación, y su campaña contra el lujo. Así, combinando trabajo duro, beneficio y abstención, el calvinismo impulsó la frugalidad y el ahorro, y orientó hacia la acumulación de capital.

Los contrastes entre Lutero y Calvino

\section{LA SOCIEDAD MEJOR}

A diferencia del luteranismo, el calvinismo no se remonta a la patriarcal y agraria forma de vida; por el contrario, reconoce la producción industrial basada en una economía monetaria como el fundamento natural de la sociedad y una forma de trabajo profesional al lado del trabajo agrícola. Mientras que Lutero pedía que se volviera en Alemania a una especie de economía patriarcal, Calvino, en Ginebra, propugnaba resueltamente el desarrollo de la industria y el comercio, pero sometiendo la actividad económica a estrictas reglas de moral [Applebaum: 1992].

Lutero condenó el comercio, pues no lo consideraba como un trabajo real; lo mismo hizo con el beneficio (ganancia), pues creía que el propósito del trabajo era la satisfacción de las necesidades y nada más. En este aspecto, se situaba aún dentro de la perspectiva católica medieval, y también creía que se debía trabajar dentro de los confines de y de acuerdo con el método del oficio o profesión en la que había nacido. Dios asigna a cada persona su lugar, y uno sirve a Dios permaneciendo en su lugar y no buscando un ascenso en la jerarquía social [Applebaum: 1992]. 
A diferencia de Lutero, Calvino consideraba indigno estar satisfecho con la clase o la profesión de nacimiento [Tilgher, 1930: 61]. Por el contrario, era deber de cada persona buscar la profesión que le podría dar el más alto retorno. Esto significaba abandonar un oficio heredado o una estación en vida, lo que estaba permitido. El trabajo quedaba libre de las inmovilizadoras ideas de casta, y dotado con la mayor iniciativa posible. Calvino estaba en contra de la utilización de las ganancias propias para el disfrute personal. Este tipo de ascetismo derivó en la idea de que el trabajo duro por el bien propio era un deber en sí mismo. Para el calvinismo, seguir una calling que no produce recompensas inmateriales era visto como una tonta pérdida de tiempo y energía. Al mismo tiempo, el fracaso en el pleno uso de las ventajas (posibilidades) era visto como indiferencia hacia Dios.

Tawney [1947] citado por Applebaum [1992: 24], sostiene que el mayor contraste entre Lutero y Calvino se refería a que Calvino aceptaba la mayor institución de una civilización comercial y suministraba un credo a las clases del futuro. Para Lutero, el mundo del comercio, banca, crédito y la industria capitalista eran parte del reino de la oscuridad que los cristianos deberían evitar. Lutero destacó la moral cristiana tradicional repudiando su diseño institucional, la búsqueda de la purificación a partir de la simplicidad del trabajo y los ordinarios deberes de vida. Denunció las fraternidades, las órdenes mendicantes, los festivales y peregrinajes. Rechazó la adquisición del mérito por medio de maquinaria especial más allá de consciente desahogo de la calling personal.

A diferencia de Lutero, que tenía una perspectiva desde el campesino y la mística, Calvino enfocó la vida económica desde el punto de vista de los negocios. Los calvinistas reconocieron la necesidad del comercio a larga escala y otros aspectos de la vida de negocios. Vieron las ganancias del comercio y las finanzas al mismo nivel de 
los trabajadores, justificando los beneficios mercantiles debido a su diligencia, industria y trabajo duro.

El concepto calvinista de calling se distinguía tanto del catolicismo como del luteranismo. Era un concepto que permitía la transición hacia un humanismo vocacional moderno [Troeltsch, 609, citado en Applebaum , 1992]. La temprana Iglesia toleraba la organización natural y las jerarquías del trabajo y la vocación, considerándolas indiferentes en relación con la salvación. Excluía sólo algunas callings (actuación, entretenimiento, carnicería, gladiadores y prostitutas). El periodo medieval trabajó el grado inferior de trabajo secular y la organización social natural en conexión con la esfera espiritual de la iglesia. Pero la iglesia medieval distinguía entre la esfera normal y secular, y la esfera espiritual. El calvinismo, y luego el protestantismo, unificaron las dos esferas. El concepto de calling elevó el trabajo ordinario y la profesión en la esfera secular al nivel de un deber religioso. Un simple método para proveer las necesidades materiales se convirtió en un fin en sí mismo, proporcionando los medios para el ejercicio de la fe mediante el trabajo en la calling de cada persona. Esto hizo emerger la idea del trabajo por el bien del trabajo, que forma uno de los supuestos sociales de la manera moderna de vivir. Fue también el calvinismo, más que el luteranismo el que se inclinó hacia el cambio y la modernidad [Applebaum: 1992].

Con el calvinismo, el pleno y lógico efecto de la noción de calling es desarrollado. Con Lutero, la visión de vocación estaba de acuerdo con san Pablo, la Iglesia temprana y la Edad Media. Para Lutero, la calling fue la actividad en la que cada uno fue colocado y en la que era una obligación permanecer, resaltando que a partir del trabajo en la devoción/profesión personal y de la red de servicio mutuo, la entera comunidad es conservada. Pero para Lutero, el orden y la prosperidad fluía desde la guía de la providencia y no de la iniciativa humana deliberada. Este era un arre- 
glo divino. El individuo estaba, en relación con su trabajo, no como una vía de contribución a la sociedad, sino como su destino señalado desde la voluntad de Dios, y que debía conservar verdadero. Este punto de vista coincidió con el pensamiento tradicional católico, y justo en este aspecto se encuentra la mayor discrepancia entre Lutero y Calvino, pues este último empujó conscientemente la creación de una comunidad santa que coordinara la actividad de los individuos y a la comunidad de una manera consciente y sistemática. El ideal calvinista rechazaba la idea de someterse a un sistema vocacional estático dirigido por la providencia, en su lugar, querían utilizar el trabajo como el método para alcanzar el objetivo de la comunidad santa. [Troeltsch 1981: 610-611; Applebaum: 1992].

\section{El protestantismo y el capitalismo}

Existe una muy extendida discusión respecto de la ética social del trabajo protestante, propiamente calvinista, que dio lugar al puritanismo en Inglaterra, y su influencia decisiva en la emergencia del capitalismo. Desde los planteamientos weberianos pareciera haber insistencia en que este cambio en la subjetividad permitió el desarrollo del capitalismo. En cambio, ciertas miradas desde el marxismo plantean que esto no pudo ser posible porque el capitalismo emergió primero como hecho material en el siglo XIX, con la revolución industrial inglesa. En ambos enfoques es evidente una especie de determinismo, subjetivo en el primer caso, y material, en el segundo.

Es importante diferenciar el calvinismo, que combina una ética ascética vocacional con la exaltación del trabajo, y que establece ciertas restricciones sobre la riqueza del capital con el moderno concepto de capitalismo, con su hedonismo, competencia dura, especialización extrema, trabajo febril, y humanismo vocacional. Todo esto corresponde a un periodo posterior, el de Adam Smith y el 
fin del siglo xviII y no encuadra con las primeras formas del espíritu burgués combinado con la religión, que recomendaba la frugalidad y modestia, y buscaba la ventaja económica en la luz de la comunidad de Dios. Esta es la ética de Franklin más que la de Bentham o Smith.

El calvinismo resaltaba el trabajo como ascetismo y el beneficio como signo de la bendición de Dios, pero sin que el beneficio excediera ciertos límites. El trabajo y beneficio no eran entendidos como un interés puramente personal, y el empresario era visto como un auxiliar para recibir los regalos divinos. Este debía incrementar su capital y utilizarlo para el bien de la sociedad en su conjunto, reteniendo para él sólo el monto necesario para satisfacer sus necesidades. Toda la riqueza excedente debía ser usada para trabajos de utilidad pública y la filantropía. La iglesia calvinista se involucró de modo importante en actividades caritativas, dando préstamos sin interés o garantía. El calvinismo predicó contra la usura y la explotación del pobre. Elementos socialcristianos son parte del calvinismo y también de una forma del socialismo cristiano.

Las teorías calvinista y luterana colocaron al individuo en relación directa con la divinidad deidad. El individuo debía enfrentar solo a Dios, sin curas, sin orientación y sin sacramentos que lo ayudaran a adquirir un estado de gracia. La confesión - la salida emocional por la comisión de un pecado-was to be done away with. En un sentido, Dios debía ser retirado enteramente de la esfera humana. Dios era trascendente e inalcanzable. Dentro de la teoría de la predestinación, si uno verdaderamente sentía la necesidad de conducir una vida de disciplina, modestia y trabajo duro, podría ser un signo de que, aunque no se podría estar seguro, se era seleccionado para la salvación.

Una cosa era cierta. Si una persona sentía la necesidad de vivir una vida de pecado, deseo, avaricia, codicia y lujuria, era un signo seguro de que no estaba destinado 
a salvarse. Por tanto, el calvinismo no era una religión de pasividad, sino de energía y trabajo duro. Las sectas que representaban la visión calvinista — como las puritanas y algunas alemanas e inglesas- mostraron en su comportamiento que básicamente eran industriosos, muy trabajadores y frugales en su degustación y hábitos [Weber, 1984; Applebaum, 1992]. ${ }^{18}$

\section{Balance}

En estas materias, sin embargo, los reformadores estuvieron de acuerdo con lo esencial: el deber de los cristianos no estribaba en retirarse del mundo, sino en actuar en él, cada uno en su lugar, con fidelidad, perseverancia y caridad. De una manera completamente natural, el trabajo pasó a ser, dentro de esta perspectiva, no solamente una obligación, sino un honor, un privilegio y un placer para quienes lo efectuaban al servicio de Dios y del prójimo [Jaccard: 1977].

La actitud protestante del trabajo es el inicio del concepto moderno de trabajo, gran cambio que se asocia con las ideas de Lutero y va mezclada con las ideas que el protestantismo tenía acerca del trabajo, siendo consideradas las precursoras ideológicas del trabajo y su ética correspondiente.

En el plano de la dinámica política y social hay que mencionar la relación entre protestantismo (en su versión puritana) y capitalismo, y entre protestantismo y democracia. No hay duda de que, por una parte, el concepto protestante de trabajo como vocación, y por otra, la moral puritana que condena el ocio y el uso irresponsable del tiempo y predica la austeridad y sobriedad frente al lujo $\mathrm{y}$ al despilfarro, han constituido gracias a su influencia,

18 Una interesante revisión histórica de la ética del trabajo puede verse en Sennet [2000]. 
un fuerte incentivo dirigido a la generación de riquezas, no con el fin de utilizarlas para el aumento del consumo, sino para el incremento de las inversiones. En este sentido, hay una afinidad entre la ética puritana y el espíritu del capitalismo, que hace pensar que el protestantismo seguramente favoreció la crisis del sistema económico feudal y proporcionó a la burguesía industrial emergente la conciencia de su papel histórico en la creación de un orden económico mundial. Aún son más evidentes los nexos entre protestantismo y democracia. Al desmantelar el orden jerárquico de los ministerios y cuestionar el concepto autoritario de la verdad e introducir formas colegiadas para el gobierno de la Iglesia, la reforma (sobre todo calvinista) y el protestantismo (sobre todo reformado) crearon las premisas para que arraigase en el pueblo una cultura democrática que no sólo incluía todas las libertades de la conciencia individual, sino también los valores laicos fundamentales (en la cultura, la política y las instituciones) que el protestantismo acogió y promovió como un reflejo en el terreno civil de su obra de desclericalización del cristianismo en todos sus aspectos [Le Goff en Diccionario Akal, 2003: 455]

Con la Ilustración, se removió gradualmente la ética del trabajo protestante de su contexto cristiano. Sin la restrictiva influencia de la creencia protestante en la primacía de lo espiritual, la doctrina de la ética protestante original se pervirtió en un credo del éxito personal. Esta perversión secularizada es a la que la mayoría de personas se refiere con ligereza como la ética protestante [Ryken, 2002: 67-70]. El desarrollo ilustrado y secularizado de la ética protestante es expresado en el siglo XVIII por Benjamín Franklin en sus proverbios en el Almanaque del pobre Richard. En estas notas no están presentes las ideas centrales de la Reforma respecto del trabajo. Por un lado, no se encuentra la convicción de que el propósito de la vida y el trabajo es glorificar a Dios y disfrutarlo eternamente. 
Tampoco están presentes las ideas de trabajo como mayordomía (encargo divino) de lo que Dios ha dado a sus criaturas y el deber moral de ayudar a los necesitados. En el lugar de la ética protestante de la Reforma, se encuentra una ética del autointerés y conveniencia; la pereza, por ejemplo [Ryken, 2002: 70].

Los reformadores rechazaron la división medieval entre trabajo sagrado y secular, y plantearon la doctrina de vocación o calling, lo que significaba que Dios llamó a la gente a trabajar en el mundo. Esto llevaba a que fuera sagrado todo trabajo cumplido para la gloria de Dios. La dignidad del trabajo común y corriente nunca permaneció tan alta como en aquel momento de la historia. Esta perspectiva santa del trabajo también le otorgó un lugar a la laboriosidad como estilo de vida y beneficio como motivación para el trabajo, aunque los reformadores predicaron un sentido de moderación en el modo de vida. Todo este proceso de afirmación del trabajo y el esfuerzo terrenal presupuso un contexto espiritual en el que la vida piadosa era supremamente valorada y la holgazanería estaba divorciada de la idea de servicio a Dios y al prójimo. Si el clásico menosprecio del trabajo fue una extensión de la visión clásica del mundo, también lo fue la actitud protestante frente al trabajo; el punto medular del pensamiento protestante era la soberanía de Dios en todos los aspectos de la vida, de este fluyó una conciencia de la creación divina del mundo y de su providencia preocupación por este. Dada esta afirmación del mundo en el que Dios ha colocado a sus criaturas como sus ayudantes, era inevitable que la tradición reformadora asociara la dignidad al trabajo humano [Ryken, 2002].

Con la reforma protestante, según Weber, el trabajo fue imbuido con una cualidad moral y convertido en la definitiva característica de la existencia humana, pues según la ética protestante, el trabajo se convirtió en una vocación religiosa, en una manera de adorar a Dios. La 
vocación religiosa se refiere a una tarea establecida por Dios. El protestantismo surge como una propuesta cristiana que criticaba la corrupción en la Iglesia católica. Esta institución, al mismo tiempo sostenía que la salvación personal podría ser lograda por medio de buenos trabajos establecidos por la Iglesia, ésta, además, generaba ingresos con la venta de indulgencias que permitían a los fieles comprar el perdón de sus pecados.

En relación con los aspectos de mando-obediencia es posible sostener que el luteranismo favorece políticamente al absolutismo y es en esencia conservador, ya que fomenta la resignación ante las injusticias del mundo y considera que las desigualdades sociales y los poderes autoritarios son voluntad de Dios [Varnagy, 1999: 158]. Este mismo autor afirma que:

La conclusión general de algunos estudiosos que se ocuparon del desarrollo histórico, de la organización y del pensamiento luterano, es que la tendencia de Lutero a minimizar la significación espiritual del poder político favorecía el apoyo de la Iglesia luterana al monopolio de todo tipo de poder temporal por parte de los nacientes Estados nacionales, así como la aceptación indiscriminada de la autoridad política en sus formas más negativas y represivas. Por eso afirma Sheldon Wolin, refiriéndose a Lutero, que "en asuntos políticos, los hombres debían obedecer sin discutir" [Varnagy, 1999: 160].

\subsubsection{GENOVESI, LOCKE Y SMITH: HACIA}

\section{LA LEGITIMIDAD E INSTRUMENTALIDAD}

Entre los siglos XVII y XVIII, el concepto eurocéntrico de trabajo, una vez ya instalado en la escena pública a partir de los aportes de Lutero y Calvino, tendrá una elaboración que conducirá, a fines de dicho periodo, a darle un signi- 
ficado muy concreto. Por un lado, se le identificará como trabajo productivo, asalariado y generador de riqueza, y por otro, se le habrá despojado de toda espiritualidad y se le revestirá de un sustrato subjetivo individualista y egoísta, en la línea de la racionalidad instrumental. En este sentido, Diez [2001: 14-15], sostiene que el arranque del discurso moderno del trabajo está teñido desde el último cuarto del siglo xv y en el contexto de la economía política de tradición mercantilista, del concepto de trabajo productivo. Lo que en esos años era un concepto vago e impreciso, sería reelaborado a lo largo de todo el siglo xvIII, abriendo una de las líneas de reflexión y diálogo llamadas a tener más alcance en la formación del lenguaje moderno del trabajo.

La narrativa eurocéntrica va planteando todo este proceso intelectual de glorificación del trabajo como algo natural, como un resultado natural y necesario en términos civilizatorios, asociado a la emergencia de la modernidad, del pensamiento científico y desarrollos filosóficos, así como del Estado moderno y de la burguesía. En un interesante texto que analiza la construcción del concepto moderno de trabajo, Durán [2006: 1-2] sostiene que la:

Modernidad se inauguró en Europa en el siglo XVI, momento a partir del cual se produjeron una serie de acontecimientos de diferente índole que alteraron gradualmente la estructura y la mentalidad de estas sociedades (ascenso de la burguesía, el Estado Moderno, la Reforma Protestante, la Nueva Ciencia y la filosofía cartesiana). Todos estos hechos acabaron convergiendo en una misma dirección, invirtiendo radicalmente la superioridad, hasta ese momento admitido, entre la vida contemplativa y la vida activa. La consecuencia de dicha inversión fue un cambio del punto de vista antropológico, cambio en virtud del cual los hombres comenzarán a ser estimados por los esfuerzos realizados para transformar la naturaleza en su propio beneficio y en el del conjunto de la sociedad. 
"Estas transformaciones, además, dieron lugar a un tipo de pensamiento" que en un periodo de tres centurias extraerá el trabajo de la oscuridad de la esfera privada para proyectarlo al primer plano del espacio público [Durán: 2006: 4]. Como se podrá apreciar en este apartado, y siguiendo la reflexión planteada en la introducción, el discurso dominante habla de una revaloración del trabajo, y hasta se sugiere una inversión valorativa favorable del trabajo manual sobre el intelectual. Sin embargo, tal mirada oculta un hecho muy importante: que este brillo otorgado al trabajo manual no significó el cuestionamiento de las relaciones de mando y obediencia verticales existentes, o de las relaciones de dominación y explotación, y mucho menos de la clasificación social, misma que se vio ampliada con el criterio de raza.

Por tanto, el planteamiento central para analizar el concepto de trabajo en la modernidad (colonialidad) es que entre los siglos XVI y XIX ocurrieron dos procesos, el primero, destacado desde la narrativa dominante, es el trabajo como generador de riqueza por medio de los aportes de los mercantilistas, los fisiócratas y los economistas clásicos y fundadores de la economía política. Esta vertiente distinguirá entre trabajo productivo e improductivo, y coronará al trabajo asalariado como el único productivo y generador de riqueza; el segundo, es la invisibilización de las anteojeras eurocéntricas de la desigualdad natural entre las personas, a partir de las ideas aristotélicas, ya explicadas en la introducción y el primer capítulo de este libro, y de la producción de la idea de raza en el siglo xvI; la primera prevalecerá entre los europeos, y la segunda, se generará respecto de los otros, de aquellos que vivían en los mundos no europeos (negros, asiáticos, indios), en esta, la idea de civilización universal que representa lo más acabado de la cultura humana, con sus instituciones centrales (propiedad privada, comercio, Estado, escritura, ciencia) y su inspiración en el progreso humano, servirá 
para legitimar la dominación y explotación entre los europeos, y para emprender el despojo y subordinación legítimos de los "salvajes" y/o "bárbaros" de las zonas no europeas, especialmente de lo que se establecería como el espacio geocultural denominado América.

Desde la primera narrativa, eurocéntrica, con la revalorización en el siglo xvi del trabajo manual con un fuerte contenido teológico, en los siglos XVII y XVIII, el concepto de trabajo se vio sometido a una elaboración asociado a la racionalidad instrumental, lo que significó su secularización en un sentido individualista y egoísta. Así, Tilgher [1930: 88-89], sostiene que:

la idea de trabajo a través de la historia ha pasado de ser vista como una expiación religiosa, obligación religiosa, como un problema ético. Luego se ha alejado de la esfera de la religión y ha adquirido mayor importancia y autoridad en sí misma, y presentada como el factor que define el éxito o fracaso del individuo. En esta última fase, la idea de trabajo estaba liberada de la ética y de la religión. Para los economistas liberales, el trabajo es una maquinaria sin espíritu. Ambos han costado dinero, y ambos deben generar beneficios.

El siglo XIX, añade Tilgher [1930:90] fue la Edad de Oro de la idea de trabajo, pues los principales líderes pensadores fueron los que exaltaron la idea del trabajo hacia una posición que nunca había tenido en términos religiosos o éticos, haciendo del trabajo la causa de todo progreso humano, intelectual y material.

Según diversos estudiosos del pensamiento social ${ }^{19}$, son varios los autores que han contribuido a generar esta visión moderna (y colonial) del trabajo: Hobbes, Locke,

19 Diez [2001], Roll [1974], Applebaum [1992], Durán, [2006] y Tilgher [1930]. 
Petty, Genovesi, Rousseau y Smith, entre otros. Marx representa la crítica más radical a esta visión, develando la explotación, la alienación del trabajo en el capitalismo ya en su fase industrial, aunque como se verá después, esta crítica se enmarca dentro de la cientificidad dominante caracterizada por el imaginario del progreso y civilización (pueblos con historia y pueblos sin historia), la relación cosificada con la naturaleza, el productivismo y la relación del trabajo como fundante de la humanidad ${ }^{20}$.

Por su importancia para los fines de este estudio, y por el tipo de argumentaciones desplegado, se revisarán los planteamientos de Locke, Genovesi y Smith en relación con el trabajo. Entre los tres hay un vínculo en el desarrollo teórico del trabajo como generador de riqueza. En este sentido según Mills [s/f]:

La idea de Locke respecto a que el trabajo fue el origen de la propiedad individual y la fuente de todo valor económico, como fue elaborada por Smith, se convirtió en la piedra de toque del sistema económico liberal: el trabajo era el factor central en la riqueza de las naciones, pero era una actividad sin espíritu, una ruda justificación para el trabajo esforzado de la población del siglo XIX, y para el hombre económico que estaba motivado a trabajar para ganar dinero.

\section{Locke}

Locke (1632-1704), considerado el fundador del liberalismo político, desarrolló una teoría del trabajo en tanto creador de valores de uso y de riqueza, y asociada a la propiedad, con la intención de legitimar la apropiación privada de la tierra y la explotación del trabajo, en un contexto de abundancia de tierras y colocando al trabajo como

20 Lander [2008], Fontana [1982], Merlo [2013], Braudillard [1973], Naredo [1987] y Quijano [2007a]. 
mecanismo que permite tal apropiación privada. Desde su visión, el Estado o la sociedad politica se constituyen en el garante de la propiedad, pues esta surge en el estado de naturaleza. El trabajo está en los prístinos orígenes del ser humano. En el estado de naturaleza lockeano el hombre trabaja con su familia. El trabajo justifica e instaura la propiedad de la tierra, y la propiedad es el factor decisivo para la aparición del gobierno, pues este nace precisamente para protegerla [Diez, 2001: 221].

Para entender la centralidad de la tierra en la teoría de la propiedad y de ésta como criterio restrictivo de los derechos políticos, es preciso entender, en primer lugar, que la tierra es para Locke un medio de producción, y en este sentido, mediada por el trabajo, se constituye en fuente de la riqueza. De aquí surge su preeminencia política: "La cuestión principal de la propiedad no es hoy la de los frutos de la tierra, ni la de las bestias que subsisten en ella, sino la de la tierra en sí misma, dado que contiene y da sustento a todo el resto" [Severo, 2013a: 7].

En su esfuerzo por desacralizar el poder del soberano y la generación de riqueza, Locke hizo una contribución fundamental respecto del concepto colonial-moderno de trabajo, sosteniendo que este crea riqueza "al incrementar con el trabajo de su cuerpo y sus manos” la producción que brinda la naturaleza ${ }^{21}$ [Naredo, 1987].

Así, Locke dará un paso más en esta misma dirección, y considerará que el trabajo, al ser la actividad que confiere valor a la mayor parte de los objetos de la naturaleza, debe estar en el origen de la propiedad:

Aunque la tierra y todas las criaturas inferiores sean a todos los hombres comunes, cada hombre, empero, tiene

21 De este modo, Locke dio un paso decisivo hacia la separación de la creación de riqueza atribuida de manera exclusiva a la naturaleza, algo que contribuirá a la reelaboración de las categorías de producción y riqueza, ambas separadas del contexto material y de la naturaleza [Naredo, 1987] 
una "propiedad" en su misma "persona". A ella nadie tiene derecho alguno, salvo él mismo. El "trabajo" de su cuerpo y la "obra"de sus manos podemos decir que son propiamente suyos. Cualquier cosa, pues, que él remueva del estado en que la naturaleza le pusiera y dejara, con su trabajo se combina y, por tanto, queda unida a algo que de él es, y así se constituye en su propiedad. Aquélla, apartada del estado común en que se hallaba por naturaleza, obtiene por dicho trabajo algo anejo que excluye el derecho común de los demás hombres. Porque siendo el referido "trabajo" propiedad indiscutible de tal trabajador, no hay más hombre que él con derecho a lo ya incorporado, al menos donde hubiere de ello abundamiento, y común suficiencia para los demás (Locke, s/f: 15).

Al vincular el trabajo con la riqueza y la propiedad, Locke introdujo un punto de vista hasta entonces desconocido. En efecto, para el pensamiento anterior, la riqueza se originaba fundamentalmente en la naturaleza, sin que el hombre interviniese de modo decisivo en su multiplicación. Sin embargo, desde la perspectiva lockeana es el ser humano quien tiene la capacidad de transformar los bienes naturales en riquezas, mediante "el trabajo de su cuerpo y la labor de sus manos”. Se abría así la posibilidad para que las actividades laborales fuesen perdiendo gradualmente los signos de vileza que las sociedades premodernas le habían atribuido [Severo, 2013a: 4].

En el Segundo Tratado sobre el Gobierno Civil, Locke esboza su visión acerca del trabajo y la propiedad desde los primeros tiempos de la humanidad, sosteniendo que Dios dio la tierra a todos en común: “(...) ora consultemos la 'revelación', que nos refiere el don que hiciera Dios de este mundo a Adán, y a Noé y a sus hijos, clarísimamente aparece que Dios, como dice el rey David, 'dio la tierra a los hijos de los hombres'; la dio, esto es, a la humanidad en común" [Mayo, 2013: 15]. 
Dios, además dio a los hombres la razón para utilizar las tierras, sin que existiera inicialmente dominio privado de ellas:

Dios, que diera el mundo a los hombres en común, les dio también la razón para que de él hicieran uso según la mayor ventaja de su vida y conveniencia. La tierra y cuanto en ella se encuentra dado a los hombres para el sustento y satisfacción de su ser. Y aunque todos los frutos que naturalmente rinde y animales que nutre pertenecen a la humanidad en común, por cuanto los produce la espontánea mano de la naturaleza, y nadie goza inicialmente en ninguno de ellos de dominio privado exclusivo del resto de la humanidad mientras siguieren los vivientes en su natural estado, con todo, siendo aquéllos conferidos para el uso de los hombres, necesariamente debe existir medio para que según uno u otro estilo se consiga su apropiación para que sean de algún uso, o de cualquier modo proficuos, a cualesquiera hombres particulares [Mayo, 2013:15].

El paso de la propiedad común a la propiedad privada se logra gracias al trabajo, actividad mediadora entre los hombres y la naturaleza:

Aunque nadie tiene originalmente un exclusivo dominio privado sobre ninguna de estas cosas [los frutos y los animales] tal y como son dadas en el estado natural, ocurre, sin embargo, que, como dichos bienes están ahí para uso de los hombres, tiene que haber necesariamente algún medio de apropiárselos antes de que puedan ser utilizados de algún modo o resulten beneficiosos para algún hombre en particular. El fruto o la carne de venado que alimentan al indio salvaje, el cual no ha oído hablar de cotos de caza y es todavía un usuario de la tierra en común con los demás, tienen que ser suyos; y tan suyos, es decir, tan parte de sí mismo, que ningún otro podrá tener derecho a ellos antes 
de que su propietario haya derivado de ellos algún beneficio que dé sustento a su vida [Locke, s/f: 56].

El paso concreto que crea la propiedad es el trabajo del hombre para sacar lo que está en la naturaleza y satisfacer sus necesidades:

Aunque la tierra y todas las criaturas inferiores pertenecen en común a todos los hombres, cada hombre tiene, sin embargo, una propiedad que pertenece a su propia persona; y a esa propiedad nadie tiene derecho, excepto él mismo. El trabajo de su cuerpo y la labor producida por sus manos podemos decir que son suyos. Cualquier cosa que él saca del estado en que la naturaleza la produjo y la dejó, y la modifica con su labor y a ella algo que es de sí mismo, es, por consiguiente, propiedad suya. Pues al sacarla del estado común en el que la naturaleza la había puesto, agrega a ella algo con su trabajo, y ello hace que no tengan ya derecho a ella los demás hombres [Locke, s/f: 56-57].

El trabajo al ser parte del hombre, es el medio para generar la propiedad sobre la tierra:

La propiedad de la tierra se adquiere también por medio del trabajo. "Toda porción de tierra que un hombre labre, plante, mejore, cultive y haga que produzca frutos para su uso será propiedad suya. ( ) Este derecho suyo no quedará invalidado diciendo que todos los demás tienen también un derecho igual a la tierra en cuestión y que, por lo tanto, él no puede apropiársela, no puede cercarla sin el consentimiento de todos los demás comuneros, es decir, del resto de la humanidad. Dios, cuando dio el mundo comunitariamente a todo el género humano, también le dio al hombre el mandato de trabajar; y la penuria de su condición requería esto de él. Dios, y su propia razón, ordenaron al hombre que 
sometiera la tierra, esto es, que la mejorara para beneficio de su vida, agregándole algo que fuese suyo, es decir, su trabajo. Por lo tanto, aquel que obedeciendo el mandato de Dios sometió, labró y sembró una parcela de la tierra añadió a ella algo que era de su propiedad y a lo que ningún otro tenía derecho ni podía arrebatar sin cometer injuria [Locke, s/f: 60].

Locke plantea que no debe haber una apropiación ilimitada de las tierras:

La misma ley de la naturaleza que mediante este procedimiento nos da la propiedad, también pone límites a esa propiedad. ( ) Todo lo que uno pueda usar para ventaja de su vida antes de que se eche a perder será aquello de lo que esté permitido apropiarse mediante su trabajo. Mas todo aquello que excede lo utilizable será de otros. Dios no creó ninguna cosa para que el hombre la dejara echarse a perder o para destruirla [Locke, s/f: 59].

Y sostiene, a partir de una idea de abundancia de tierras (en América), que la apropiación de la tierra no ha significado el perjuicio de nadie:

Esta apropiación de alguna parcela de tierra, lograda mediante el trabajo empleado en mejorarla, no implicó prejuicio alguno contra los demás hombres. Pues todavía quedaban muchas y buenas tierras, en cantidad mayor de la que los que aún no poseían terrenos podían usar. De manera que, efectivamente, el que se apropiaba una parcela de tierra no les estaba dejando menos a los otros; pues quien deja al otro tanto como a éste le es posible usar, es lo mismo que si no le estuviera quitando nada en absoluto [Locke, s/f: 61].

Es evidente que Locke trata de legitimar la propiedad privada, y lo hace partiendo del trabajo; sostiene que, 
como los hombres requieren de la naturaleza para satisfacer sus necesidades, el trabajo es condición ineludible de la existencia humana. Al mismo tiempo, propone que, si la propiedad privada tiene su origen en el trabajo, se concluye que también es una condición permanente de la existencia humana. La propiedad se hace extensiva no sólo a los frutos de la tierra, sino a la tierra misma, bajo el supuesto de la abundancia [Mayo, 2013: 3-4].

Esta idea de Locke respecto del trabajo y la propiedad parte de la visión eurocéntrica de la vida buena, es decir, de la universalización de la historia occidental para todo espacio y tiempo, a partir de los intereses sociales de los propietarios y para justificar el despojo de las tierras a los pueblos originarios de lo que hoy es Estados Unidos de América, con el fin de que explotadas de manera racional y eficiente: siguiendo las prácticas de cultivo occidentales y buscando la ganancia.

En el personaje, considerado el fundador del liberalismo, hay una condición elitista de la igualdad y la libertad, pues la idea de igualdad ciudadana no se basa en la igualdad entre las personas, sino en el acceso desigual a la propiedad de la tierra, de modo que las funciones de mando deben ser desempeñadas por los propietarios. De este modo, hay una relación clara entre la propiedad o acceso a una determinada superficie de tierra y el ejercicio de los derechos políticos. Los argumentos de Locke están destinados a legitimar de manera universal una apropiación muy desigual de la tierra a favor de los dueños de la tierra. Para el caso de Carolina del Norte, Locke diseñó la constitución y el reparto de tierras para ocho señores propietarios, por parte del rey Carlos II de Inglaterra. El esquema de reparto de tierra era muy desigual, pues favoreció de manera notable a los propietarios y a la nobleza en perjuicio de los colonos libres, los siervos, y sobre todo, los indígenas, quienes habían sido despojados de sus tierras [Severo, 2013b]. 
Así, en la Constitución de Carolina del Norte, se establece que:

este territorio, según se estipula, será dividido en diferentes distritos, que habrían de conservar una misma proporción distributiva: doce mil acres de los Señores Propietarios, doce mil acres de la nobleza (barones, en su mayoría herederos de los Señores Propietarios o a legados de la máxima confianza) y doce mil acres para su colonización. Sin embargo, los doce mil acres de las colonias no serían exclusivamente cedidos a colonos libres, sino que con el fin de velar por "el equilibrio del gobierno", un quinto de esta extensión sería propiedad de los Señores Propietarios y otro quinto de la nobleza. Las restantes tres quintas partes de la colonia serían distribuidas entre los colonos libres, que habrían de pagar un tributo a los Señores Propietarios por detentar el dominio de la tierra y ejercer su actividad productiva en la provincia de Carolina [Severo, 2013b: 3].

De acuerdo con este esquema, el reparto inicial de tres tercios para cada grupo social terminó siendo cuatro quintas partes para la nobleza y los propietarios y de una quinta parte para los colonos libres.

Estos señores propietarios, además de concentrar las tierras, se encargarían del gobierno y la administración de justicia. Los colonos libres, lejos de contar con independencia y derecho de apropiación a partir del trabajo, requerían la concesión de los señores propietarios para poseer derechos de propiedad, a cambio de un tributo a perpetuidad. El otro segmento de la población era el de los siervos, quienes como sus hijos, estaban destinados al vasallaje por todas las generaciones. Los siervos estaban asociados a un determinado dominio territorial, requerían un permiso especial de movilidad y eran vendidos junto con los terrenos destinados a la explotación colonial. Finalmente, la Constitución de Carolina del Norte prohibía a 
todo habitante, la compra o venta de tierras a los nativos de América, sin la mediación de los señores propietarios, bajo pena de destierro a perpetuidad y confiscación completa de sus bienes [Severo, 2013b: 3-4]. Al mismo tiempo, la condición básica para ejercer la ciudadanía es la propiedad de la tierra: la constitución estipula que quien se postule como agente o suboficial de policía de una colonia debe contar con cien acres de tierra. La postulación a juez y administrador en la corte del distrito demanda contar con trescientos acres; ser jurado de la corte del condado, la posesión de al menos trescientos acres; ser jurado de la corte del señor propietario exige poseer quinientos. Votar en la elección de estos representantes de los colonos, demanda la posesión libre de al menos cincuenta acres [Severo, 2013b: 4].

La mirada de Locke también estaba teñida de colonialidad, es decir, de racismo, al plantear que la abundancia de tierras en América se basaba en desconocer a los indígenas que habitaban el subcontinente, puesto que seguían viviendo en estado de naturaleza, sin propiedad privada ni Estado.

Locke destaca la ventaja de la producción bajo propiedad privada respecto de la propiedad comunal:

no es tan extraño como, tal vez, antes de su consideración lo parezca, que la propiedad del trabajo consiguiera llevar ventaja a la comunidad de tierras, pues ciertamente es el trabajo quien pone en todo diferencia de valor; cada cual puede ver la diferencia que existe entre un estadal plantado de tabaco o azúcar, sembrado de trigo o cebada, y un estadal de la misma tierra dejado en común sin cultivo alguno, y darse cuenta de que la mejora del trabajo constituye la mayorísima parte del valor ( ) No puede haber demostración más patente de esto que la constituida por diversas naciones de los americanos, las cuales ricas son en tierra y pobres en todas las comodidades de la vida; proveyólas la naturaleza tan liberalmente como a otro cualquier pueblo con los ma- 
teriales de la abundancia, esto es con suelo fructífero, apto para producir copiosamente cuanto pueda servir para la alimentación, el vestido y todo goce; y a pesar de ello, por falta de su mejoramiento por el trabajo no disponen aquellas naciones de la centésima parte de las comodidades de que disfrutamos, y un rey allí de vasto y fructífero territorio, se alberga y viste peor que cualquier jornalero de campo en Inglaterra [Locke, s/f: 20-21].

Al mismo tiempo, Locke planteó que en los casos en los cuales las poblaciones en estado de naturaleza se resistieran a ceder sus tierras, era lícito emprender una guerra justa para hacerse de las tierras y esclavizar de manera legítima a la población: "La esclavitud legítima tenía como destinatario al nativo de América, pues Locke 'asume la resistencia del nativo en la tierra sin cultivar, y que él da por descontada la justicia del desarrollo de la «resistencia» a tal "agresión»" [Glausser, 1990: 209 y Arneil, 1992, citados por Severo, 2013a].

Según Glausser, en la medida en que la tierra es apropiada por el criterio del trabajo, y para Locke los nativos no cultivan la tierra, si resistieran la colonización sentarían las bases para una guerra justa en su contra por parte de los colonos. Esta tesis se enmarca en las líneas generales de nuestra interpretación, en la medida en que comprende que la figura de esclavitud legítima sólo puede abarcar a los hombres no incorporados en sociedades civiles. En efecto, para que sea posible la aplicación del argumento de la guerra justa entre privados, no puede aplicarse sino a los nativos extraeuropeos [Severo, 2013a].

Desde la colonialidad-modernidad puede verse la tensión en el pensamiento de Locke: defiende la igualdad, la propiedad y la libertad como valores supremos del individuo propietario, pero al mismo tiempo, propone medidas para la apropiación desigual de la tierra mediante el trabajo y no considera como iguales a los indígenas de 
Norteamérica. A esto se suma su participación concreta en el tráfico de esclavos ${ }^{22}$.

Farr [2008, citado por Severo, 2013a] plantea el problema en términos de contradicción entre la imagen contemporánea de Locke como teórico del liberalismo y su usufructo del tráfico de esclavos, marcando un abismo entre la teoría de la propiedad lockeana y su biografía. El teórico eminente de los derechos naturales y de la libertad humana era él mismo un aventurero en el comercio de esclavos africanos y un instrumento de la política colonial británica, que propuso legislación para garantizar que "todo hombre libre de Carolina tendrá poder y autoridad absolutos sobre su esclavo negro". Locke, sostiene Farr, nunca mencionó, y mucho menos resolvió, esta contradicción.

Se trata de presentar un discurso parroquial, dice Lander [2000], el de Europa, como universal y único en relación con todo lo no europeo; esto es un discurso eurocéntrico respecto del europeo y el no europeo desde la posición privilegiada del lugar de enunciación asociado al poder imperial, que se inicia con los cronistas españoles. El mismo Lander [2000], basándose en Clavero [1994], sostiene que esta construcción tiene como supuesto básico el carácter universal de la experiencia europea, siendo las obras de Locke y Hegel influyentes y paradigmáticas. Al crearse la noción de la universalidad a partir de la experiencia particular (o parroquial) de la historia europea y hacer la lectura de la totalidad del tiempo y espacio de la experiencia humana a partir de esa particularidad, se erige una universalidad radicalmente excluyente. Cla-

22 Respecto de Locke y la esclavitud, ver Cranston [1957]. Y en cuanto a Locke y el colonialismo inglés, puede consultarse Ulas-Ince [2012], así como Uzgalis [2002-2007] y Squadrito [2002-2007], en torno a una discusión encontrada respecto del racismo en la filosofía de Locke. Severo [2013a], por su parte, no considera el racismo como un argumento que justifique la esclavitud en Locke. 
vero analiza las concepciones del universalismo y del individuo y sus derechos en el liberalismo clásico y en el pensamiento constitucional, sosteniendo que es un universalismo no universal, en la medida en que niega todo derecho diferente al liberal, que está sustentado en la propiedad privada individual. La negación del derecho del colonizado comienza con la afirmación del derecho del colonizador; lo es de un derecho colectivo por un derecho individual. Locke, en el Segundo Tratado sobre el Gobierno Civil concibe más concretamente ese derecho como derecho de propiedad, como propiedad privada, por una razón muy precisa. Para él, la propiedad es derecho ante todo del individuo sobre sí mismo. Es un principio de disposición personal, de esta libertad radical. Y el derecho de propiedad también puede serlo sobre las cosas en cuanto que resulte del ejercicio de la propia disposición del individuo, no sólo sobre sí mismo, sino sobre la naturaleza, ocupándola y trabajándola. Es el derecho subjetivo, individual, que constituye, que debe así prestar constitución, al derecho objetivo, social. El orden de la sociedad habrá de responder a la facultad del individuo. No hay derecho legítimo fuera de esta composición. Let him [the Man] plant in some in-land, vacant places of America (que el hombre así colonice las tierras vacantes de América), un territorio que puede considerarse jurídicamente vacío porque no está poblado de individuos que respondan a los requerimientos de la propia concepción, a una forma de ocupación y explotación de la tierra que produzca ante todo derechos, y derechos antes que nada individuales. Si no hay cultivo ni cosecha, ni siquiera la ocupación efectiva sirve para generar derecho, otros usos no valen, esa parte de la tierra, este continente de América, aunque esté poblado, puede todavía considerarse vacante, a disposición del primer colono que llegue y se establezca. El aborigen que no se atenga a esos conceptos, a tal cultura, no tiene ningún derecho. He aquí el punto 
de llegada del discurso propietario, punto de partida de la concepción constitucional. Y no es desde luego una mera ocurrencia de un pensador aislado. Estamos ante una manifestación realmente paradigmática de toda una cultura, quizás todavía la nuestra. Para la perspectiva constitucional, para esta nueva mentalidad, los indígenas no reúnen las condiciones para tener derecho alguno, ni privado ni público.

\section{Genovesi}

Antonio Genovesi (1712-1769) fue sacerdote y profesor de Economía Política en la Universidad de Nápoles. Estuvo a cargo, en 1754, de la primera cátedra de economía en el mundo, titulada "De mecánica y de comercio". Su presencia en el escaparate de figuras que han contribuido al pensamiento económico occidental es marginal porque se le atribuyó un pensamiento mercantilista que fue estigmatizado por el librecambismo, que describía el conjunto de ideas económicas que dominaron los ambientes políticos y comerciales europeos en los siglos XVI, XVII y buena parte del xVIII, sintetizadas en el monopolio exportador, control de cambios y balanza comercial. Aunque era difícil identificar un sistema en relación con aquellas ideas, el calificativo de mercantilista sirvió a los objetivos políticos de los economistas que abogaban por el librecambismo en el siglo XIx. Genovesi fue seguidor de Locke y de la teoría contractualista, racionalista, utilitarista e individualista. Recientemente, su obra está siendo revisada a partir de sus propuestas referentes a la fe pública, y a su concepción de la economía civil diferenciada a partir de la noción de reciprocidad, de la smithiana economía política, utilitarista e individualista [Giglio, 2014: 3].

En su libro Lecciones de comercio y economía civil publicado en 1786, Genovesi se interesa en la afirmación del poder del Estado. Para él, la economía civil, desde una 
visión estatalista, significa población, comodi, richezza e potenza, planteando que la fuerza de un Estado se basa en tener el mayor número posible de habitantes, que el trabajo, il capitale dei poveri, es la principal fuente de producción, y que el incremento de la producción significa alcanzar la riqueza y el poder del Estado. A este fin se orientan las actividades económicas: agricultura, manufacturas y comercio, otorgando la primacía a la agricultura en la producción de riqueza. Genovesi enunció el principio del trabajo, como productor de riqueza, en el contexto de un absolutismo ilustrado, en el que el príncipe asume la función más importante como impulsor del reformismo [Laurenco, 1999: 4-5] ${ }^{23}$.

El aporte de Genovesi al concepto moderno (colonial) de trabajo, no sólo es importante porque plantea el rol del trabajo en la generación de riqueza, sino porque establece una diferenciación entre trabajo productivo y trabajo improductivo, en la línea de pensamiento que pocos años después se establecería como canónica con la publicación en 1776 de la obra cimera de Smith, La riqueza de las naciones.

Al respecto, Durán [2006: 4-5] sostiene que "desde los presupuestos mercantilistas, el trabajo se convirtió también en materia de interés y de reflexión pública”, por entenderse que era una de las principales fuentes generadoras de riqueza. Riqueza que se equiparó en la teoría mercantilista al concepto de valor-utilidad, de ascendencia escolástica. Con arreglo a este principio, el valor de un objeto y su utilidad, estarán en función de las necesidades que satisface. Tal como sostiene el napolitano Antonio

23 Según Laurenco [1999], Genovesi difícilmente puede ser reducido a mercantilista o fisiócrata, pues si bien defendía las medidas proteccionistas en cuanto al comercio exterior, al mismo tiempo difería de los fisiócratas al sostener que había una interdependencia entre la agricultura y la manufactura en la producción de riqueza; mientras que la fisiocracia consideraba a la manufactura como una actividad inútil. 
Genovesi: "las necesidades son el origen del valor de todas las cosas y el precio de éstas es el poder que tiene de satisfacer nuestras necesidades".

El trabajo adquirió, en el contexto de esta argumentación, un papel de primer orden, al ser la actividad que suministraba a la nación los objetos imprescindibles para cubrir todas sus necesidades, mejorando de este modo el bienestar de su población e incrementando la riqueza de la República. Las actividades laborales que aportaban más eficazmente a la producción (principalmente la agricultura) de estos objetos, gozaban, por tanto, de la estima pública; lo contrario sucedía con aquellas otras que nada aportaban en este sentido. A partir de este criterio, se estableció una importante diferenciación entre el trabajo productivo, destinado a la generación de valores de uso, y del improductivo, que resultaba estéril desde esta perspectiva. Al mismo tiempo, el trabajo se constituyó en el criterio de diferenciación y clasificación social, pues dentro del discurso mercantilista, no sólo era una obligación moral que el gobierno debía promover a toda costa, sino también era el medio principal para el progreso de los individuos en el seno de la sociedad, lo que constituyó una crítica al criterio tradicional de estatus [Diez, 2001; Durán, 2006].

\section{LA CLASIFICACIÓN DE ACTIVIDADES PRODUCTIVAS} E IMPRODUCTIVAS

Para Genovesi, si el trabajo era la fuente del valor de uso y de la riqueza, la sociedad debía verse como una sociedad ocupada [Diez, 2001]. En su visión evolucionista y eurocéntrica de la historia, Genovesi planteaba que el estudio de la división del trabajo debía considerar la fase histórica en que se encontraba cada sociedad, distinguiendo naciones salvajes, bárbaras y cultas, sin comercio y con comercio [Genovesi, 1786: 51]. Las primeras (Canadá y Laponia) desconocen la labranza, las artes y letras, carecen 
de leyes políticas y se mantienen de la caza y pesca; las segundas (México y Perú al momento de la conquista) son las "que á más de apacentar rebaños de animales conocen la agricultura y saben algo de las artes de primera necesidad". Las cultas sin comercio (pueblos de la Alemania interior) practican las expresadas artes, pero presentan poca finura en sus obras, ignorancia de las artes de lujo. Las naciones con comercio "y perfectamente cultas, son las que trabajan con el mayor primor todas las artes de necesidad, de comodidad y de luxo; y en las que las ciencias más profundas, las bellas letras y el buen gusto, se cultivan de modo, que ascienden cada día al mayor grado de perfección". Al mismo tiempo, plantea la distinción entre dichas sociedades a partir del tipo de gobierno: "Entre los Salvages, no hay Imperio fixo, y suelen gobernarse por una Teocracia cruel. Entre los Bárbaros se halla una potestad civil, y permanente pero todavía muy informe. Solo en los pueblos civilizados tenemos un gobierno estable, con sistema, con orden, y con arreglo" [Genovesi, 1786: 52 $]^{24}$. Por tanto, en las naciones "civilizadas", según Genovesi, se daba una amplia división del trabajo en términos económicos y de mando-obediencia. Sostenía, así, que:

en las poblaciones de los Bárbaros ya se encuentran Gefes políticos, y leyes que se conservan por tradición, ó que pasan de unos á otros en canciones. Hay también pastores y caza-

${ }^{24}$ En el espíritu lockeano (discutido en el apartado anterior), que establecía el derecho de los europeos a colonizar tierras en otras partes del mundo donde no había propiedad privada y Estado, Genovesi comentaba:

No pretendo aquí aprobar la guerra, pues ántes la considero por una de las mayores plagas, que Dios envía al Género humano. Pero en este problema: ¿Si se puede justamente permitir a un pueblo el extenderse por otros países, y ocupar nuevas tierras incultas, quando el terreno que ocupa no basta á su subsistencia, por el excesivo número de sus habitantes? no hallo razón que me impida estar por la afirmativa: porque es de derecho natural el procurar vivir, y la tierra, en caso de necesidad, es un patrimonio común [Genovesi, 1786: 91]. 
dores, pero á más de estos, hay otros que cultivan la tierra, algunos que trabajan en las artes de primera necesidad; y quasi todos manejan las armas en la guerra. Empiézase á respirar en estos pueblos un ayre mas libre, y se halla entre ello mas humanidad. En este estado se hallaban los Peruvianos y Mexicanos, cuando fueron conquistados por los Españoles (...) Las letras y los Colegios donde se cultivan son el principio de la civilidad de un país, poniendo leyes fixas, que cimienten, y arreglen la Soberanía. Constituido ya el Estado, el gobierno se mueve mejor, crecen las artes, se mejoran las manufacturas, y se aumentan las clases de las personas. Estos Estados son la verdadera pirámide del Caballero Temple. El punto más alto es el Soberano: siguen los Grandes y Magnates de la Corte (...) luego los elevados por nacimiento, ó por sus empleos (Ministros de las leyes, de la Religión, y los oficiales del Exército) (...) inmediato á estos, los nobles los Abogados, los profesores de las ciencias, los Médicos, los Cirujanos y los Boticarios; posteriormente los comerciantes, los que exercen las artes de luxo, las secundarias y las primitivas: finalmente (...) una clase de poltrones, holgazanes y mendigos (...) En esta pirámide la basa son los que trabajan las artes primeras y fundamentales (Artesanos), y el pedestal los que se emplean en las artes secundarias, que sirven para mejorar las primeras (Artífices) [Genovesi, 1786:52-55].

En síntesis, según Genovesi, las clases de los "pueblos cultos” están conformadas según el siguiente orden, de abajo hacia arriba:

Primera: la de los hombres que producen y cultivan. Segunda: la de los que trabajan las artes de primera necesidad. Tercera: la de los que trabajan las artes útiles, y secundarias. Quarta: la de los que se exercitan en las artes de puro luxo. Quinta: la de los empleados en el Ministerio y gobierno. Sexta: la de los empleados en la Milicia. Séptima: la de 
los Grandes. Todo el cuidado, y toda la mira del gobierno económico de un Soberano y sus Ministros, debe dirigirse á estos siete puntos [Genovesi, 1786:56].

Así, Genovesi propuso una clasificación social (entre ocupaciones productivas y ocupaciones ociosas) que reconoce la necesidad de incluir diversas funciones sociales legítimas, pero según un criterio de proporcionalidad que conlleva un principio de racionalidad económica, estableciendo tres categorías: 1) personas que producen inmediatamente, 2 ) personas que no producen inmediatamente y 3) personas no productivas, sosteniendo que la cantidad de personas no productivas debía reducirse a lo mínimo posible para no afectar la riqueza del Estado [Diez, 2001: 39]. La primera clase estaba formada por cazadores, pescadores, labradores, pastores, mineros, artesanos, fabricantes, etc. La segunda, por los que distribuyen y conservan los bienes; si son escasos, decae la industria que se alienta del monopolio comercial, si son excesivos, faltarán los brazos a la primera clase. La tercera clase — también de efectivos útiles que no producen inmediatamente - es de servicio: protección, educación y religión. La última clase es la de los puramente improductivos y socialmente dañinos. Por el criterio de racionalidad económica, el primer segmento (trabajadores productivos) debe incrementarse lo máximo posible sin más límites que el propio pleno empleo; los indirectamente productivos (segundo y tercer segmentos), deben ser limitados para no perjudicar el desarrollo nacional. Los improductivos y considerados socialmente dañinos debían ser restringidos drásticamente o erradicarse en su totalidad. A los improductivos (criados, sirvientes, regatones, etc.), debía aplicárseles con rigor la ley del mínimo, mientras que las ocupaciones dañinas (comediantes, músicos de la legua, prostitutas y ocupaciones asociadas) debían ser erradicadas del cuerpo social [Diez, 2001]. 
En sus “Lecciones..." Genovesi sostenía que:

Todos los hombres, que por sí no producen inmediatamente, y se mantienen de lo que los otros trabajan, deben reducirse al menor número posible, regulándose esto con las necesidades y las fuerzas del Estado. Este mínimo posible es la gran ley política en este número de personas, pues si es excesivo, debilita las rentas y minora los operarios, que deben emplearse en las artes; y si es demasiado pequeño, no es suficiente para la defensa del Estado, y puede por esto ocasionarse una gran pérdida en el comercio y la industria" [Genovesi, 1786:172].

\section{Continúa:}

En esta situación está el ejército; luego siguen los Magistrados, Jueces, Abogados, Procuradores, Agentes, Escribanos, Notarios y otros de menor rangos, que son ministros y depositarios de la fe pública, quienes en conjunto pueden llamarse la clase defensora de nuestros derechos [Ibíd.:174].

Siguen los médicos, cirujanos, boticarios, químicos, farmacéuticos, y otros subordinados a estos. Continúan los ministros del Altísimo, seculares y regulares. Y después, la clase

en que se hallan todos los que sirven á nuestras comodidades, y á nuestros placeres, y dan salida a las materias primas modificadas por las artes: tales son los comerciantes, tenderos, botigueros, caleseros, arrieros, criados y sirvientes, y otra muchedumbre de gentes que se encuentran en los países cultos, especialmente en las Ciudades grandes, y sin las cuales no podría absolutamente el luxo. A estas personas es preciso añadir otras que se emplean en divertir la ociosidad de muchos que abundan en las Capitales, como son los músicos, los cómicos, los bailarines, los charlatanes, 
los que hacen habilidades, y otros embusteros y charlatanes [Ibíd.: 179].

Por debajo de estas ocupaciones estarían aquellas que, aun no siendo directamente productivas, garantizarían, sin embargo, el buen funcionamiento de las que sí lo son. Éste sería el caso del gobierno, la milicia, la educación, e incluso, tal como habíamos señalado anteriormente, de la religión. El gobierno, promueve leyes económicas y vigila que "no haya en el cuerpo civil persona que no sirva para algo como esté hábil para ello”. La milicia protege los intereses nacionales frente a los extranjeros; la educación instruye a los hombres en sus oficios y la religión anima a los hombres cumplir el trabajo [Genovesi, 1786: 26-29]. Todas estas actividades encontrarán así su verdadero sentido en servir del modo más eficaz a las distintas necesidades humanas. Siendo éste el criterio principal para lograr una sociedad bien ordenada [Durán, 2006: 6].

Genovesi plantea, en concordancia con su planteamiento del trabajo productivo, la necesidad de prevenir contra clases que tienen rentas e ingresos de manera no legítima, es decir, al margen de su utilidad ocupacional al servicio de la paz, el orden, la justicia, la instrucción, la ciencia y los servicios espirituales. Las clases inútiles son un poderoso generador de trabajo improductivo, sin justificación posible, tanto por el consumo conspicuo de servicios ineficaces - trabajo doméstico- que generan, como por ser los emisores sociales de los mensajes y símbolos que enaltecen, sustentan y justifican las formas infructíferas de vida.

EL TRABAJO COMO DIFERENCIACIÓN SOCIAL

Y LA CONTRADICCIÓN NO VISIBLE

La clasificación social con base en las ocupaciones productivas e improductivas establece un criterio de dife- 
renciación social distinto al de la sociedad jerárquica estamental. Así, Genovesi sostenía que el trabajo era el criterio básico de reconocimiento social, y destacaba que "aquellas (clases) de personas que se hallan en el grado más baxo de la República deben aplicarse con mas ahinco, y particularidad, si desean ascender á otro mas alto, siendo la fatiga la escala de los honores" [1786: 64]. Esto significaba una importante revalorización del trabajo manual, dada su condición de productivo, y por tanto, de creador de bienes útiles y de riqueza.

¿Significaba este giro valorativo del trabajo manual un cambio sustancial en la valoración social de los trabajadores y en las relaciones de mando-obediencia verticales? La respuesta parece negativa, pues para Genovesi, los trabajadores, pese a su condición de trabajadores productivos y de generadores de la riqueza nacional, seguían teniendo una condición subordinada, de acuerdo con la visión aristocrática que ha nutrido el pensamiento occidental respecto del trabajo, ya que para los sectores dominantes el trabajo manual era y es poco valorado, dada su mecanicidad, en contraposición al trabajo intelectual que requiere reflexión y deliberación.

Así, Genovesi se refiere al trabajo productivo como artes primitivas o mecánicas, mostrando la influencia aristotélica respecto de la valoración del trabajo manual. Al mismo tiempo, esta valoración del trabajo manual no significa un cambio en la percepción respecto de una modificación de los lugares que ocupan los diversos sectores sociales en las relaciones de mando-obediencia. Genovesi sostenía que:

la prosperidad de una nación estaba en relación con el grado de atención que el gobierno diera a los trabajadores: aquella Nación será feliz, próspera, y floreciente, en donde se hallen bien unidos los cuidados del Soberano, los de los Grandes, los de los Nobles, los de los Doctos, los de los Ministros de 
la Religión, y al mismo tiempo bien arreglados los exercicios de la plebe [Genovesi, 1786: 64].

Destaca la utilidad y necesidad del trabajo y su obligatoriedad moral, y que cuanta más gente trabaje en un país, más riqueza habrá. Reitera, al mismo tiempo, con un discurso que naturaliza el trabajo para las clases subordinadas, sosteniendo que cuantos más trabajadores haya en las actividades productivas básicas mayor será la riqueza de los propietarios. De este modo, Genovesi sostiene que:

las primeras máximas en que debía imbuirse a la niñez, son que el hombre ha nacido para trabajar: que el trabajo es obligación de todos: que no solo es necesario, sino útil: que no se puede vivir sin él: que ninguno puede estar seguro en un país en donde se pretende comer sin trabajar. El trabajo es el capital de todas las personas, de todas las familias, y de todas las clases. Quantos menos hay que dexen de trabajar, tanto mejor se halla el país [Genovesi, 1786: 202]. El labrador, el marinero, el pastor, el mercader, el texedor, y en fin todos los que trabajan, y se exercitan en las artes, alimentan y sostienen la grandeza de los magnates, que será tanto mayor, quanto mayor sea el número de los que se emplean en ellas, y quanto mas florecientes y pujantes se hallen en una Nación [Ibíd.: 59]. La caza, la pesca, la pastoril, la agricultura y la metalurgia son, como se ha dicho, las cinco artes fundamentales de cualquier estado, y las que producen las materias primas, que son el nervio de la nación [Ibíd.: 105].

EL TRABAJO CREADOR DE VALORES USO Y EL PRECIO EN RELACIÓN CON EL TIPO DE NECESIDADES SATISFECHAS

No obstante, el trabajo al que se refiere el mercantilismo aún no ha traspasado el umbral de las utilidades concretas, cuyo objetivo último sería hacer más fácil y agradable la vida del ser humano sobre la tierra. La investigación 
mercantilista se orientará, pues, a averiguar cómo las personas que integran las distintas ocupaciones productivas pueden "contribuir al adelantamiento de las artes, al aumento de las riquezas, y, por consiguiente, a su común felicidad" [Genovesi, 1786: 34]. Desde esta perspectiva, se clasificarán los diferentes oficios atendiendo a las distintas necesidades humanas que satisfacen: "Unas que son de pura naturaleza, otras de comodidad y muchas de regalo y delicadeza" [Ibíd.: 35]. Este será también el principal criterio para valorar los objetos producidos con el trabajo humano. "Infiérese de aquí que las necesidades son el origen del valor de todas las cosas y el precio de éstas es el poder que tienen de satisfacer nuestras necesidades" [Ibíd.: 36]. Por consiguiente, el precio de cualquier mercancía, su valor, estará en relación directa con la capacidad que tiene para atender de forma eficaz al mayor número de las necesidades humanas. Dicho de otro modo: "nace de la estimación y común opinión que (el pueblo) tiene de las cosas y de los signos que circulan" [Ibíd.: 37].

Por encima de esta opinión, ninguna "ley puede subir o bajar los precios de las cosas sin violentar la naturaleza de las mismas" [Ibíd.: 38]. En suma, en el contexto del discurso mercantilista el precio es un concepto social que se forma a partir de las necesidades y las inclinaciones de los miembros de una determinada colectividad. En este, como en algunos otros aspectos, el mercantilismo se reveló como una mentalidad todavía preindustrial, ajena por completo a cualquier noción abstracta de riqueza vinculada a una inexistente economía de mercado. De acuerdo con esta forma de pensar, la riqueza estaba constituida por el conjunto de bienes que engrandecían el Estado elevando el bienestar y el grado de felicidad de la población. En otras palabras, dicha riqueza se expresaba en términos sociales y políticos antes que económicos. Si el trabajo era tan importante, si merecía tal grado de consideración, era porque hacía a la monarquía más fuerte 
y poderosa, y a sus súbditos, más prósperos y dichosos. No obstante, aun mereciendo tan alta estima, todavía se entendía que la actividad laboral no podría crear ninguna riqueza sin la presencia de la naturaleza. Pese a todos estos elementos tradicionales, el mercantilismo supuso una etapa decisiva en el encumbramiento del trabajo. Al hacer de esta actividad uno de los principales instrumentos para la generación de riqueza, elevó enormemente su consideración hasta convertirla en uno de los principales criterios para estructurar y ordenar el conjunto de la sociedad [Durán, 2006].

\section{Adam Smith}

Adam Smith (1723-1790) nació en Escocia y estudió en las universidades de Glasgow y Oxford. En 1751 ocupó la cátedra de Lógica en la Universidad de Glasgow, y en 1752, la de Filosofía Moral. En 1777 fue nombrado comisario real de Aduanas de Escocia.

A fines del siglo XVIII, Smith estableció el consenso dominante acerca de lo que era la economía política como ciencia ${ }^{25}$, teniendo como base el proyecto moderno asociado a la razón instrumental. En la colonialidad-modernidad, Smith, sin duda alguna, fue quien elaboraría la síntesis mayor del trabajo en tanto asalariado y productivo, creador de riqueza, y plantearía la importancia del trabajo productivo para la acumulación de capital.

25 Según Smith [2014: 377]: "la economía política, considera como uno de los ramos de la ciencia del legislador o del estadista, se propone dos objetos distintos: el primero, suministrar al pueblo un abundante ingreso o subsistencia, o, hablando con más propiedad, habilitar a sus individuos y ponerles en condiciones de lograr por sí mismos ambas cosas; el segundo, proveer al Estado o República de rentas suficientes para los servicios públicos. Procura realizar, pues, ambos fines, o sea enriquecer al soberano y al pueblo". 
RACIONALIDAD MEDIOS-FINES Y RACIONALIDAD HISTÓRICA: UTILITARISMO Y EGOÍSMO

Para ubicar en su real dimensión el aporte de Smith a la concepción eurocéntrica de trabajo, es importante tener en cuenta la existencia no de uno, como la narrativa eurocéntrica sostiene, sino de dos proyectos modernos surgidos con la Ilustración europea, principalmente desde fines de los siglos XVII y XVIII. Uno, el proyecto continental, representado principalmente por Francia, y el otro, el de Europa del Norte, con Inglaterra y Escocia como sus mayores exponentes.

Según Quijano [1988], desde la Ilustración, y en particular desde la Revolución francesa y la llamada revolución de Estados Unidos de América, se dibujaron dos propuestas de modernidad, una asociada al capital y otra al trabajo, ambas articuladas en el patrón eurocéntrico de poder. La primera enlazaba el individualismo y la razón instrumental, y la segunda, la igualdad social con la razón histórica. Así, en los países del norte o sajones, la razón instrumental es una relación entre fines y medios. Lo racional es lo útil. Y la utilidad adquiere su sentido desde la perspectiva dominante, es decir, del poder. En cambio, en los países del sur, entre ellos Francia, la idea predominante de racionalidad se constituye especialmente en el debate acerca de la sociedad, vinculada, en primer término, a la definición de los fines, los de la liberación de la sociedad de toda desigualdad, de la arbitrariedad, del despotismo y del oscurantismo, contra el poder existente. La modernidad se constituye allí, como una promesa de existencia social racional, en tanto que promesa de libertad, de equidad, de solidaridad, de mejoramiento continuo de las condiciones materiales de esa existencia social, no de cualquier otra. Esa diferencia se convirtió en una cuestión crucial para el destino de la modernidad y de sus promesas, en la medida en que la hegemonía en 
el poder del capital, en las relaciones de poder entre las burguesías en Europa se fue desplazando ya desde el siglo XVIII, pero sobre todo en el XIX, hacia el control de la burguesía británica. De ese modo, la vertiente angloescocesa de la Ilustración y de la modernidad se impuso sobre el conjunto de la razón burguesa, no solamente en Europa, sino también a escala mundial debido al poder imperial mundial que la burguesía británica logró conquistar. La razón instrumental se impuso sobre la razón histórica.

Esta mirada a las dos modalidades de modernidad es también resaltada por Rosales [2005: 121-125, 135-136] en un estudio acerca de la vigencia del pensamiento de Hume, otro exponente de la Ilustración escocesa. Rosales evalúa las diferencias entre ambas vertientes a partir de la concepción del progreso. El tronco común que hermanaba a ambas tenía los siguientes rasgos:

- la producción histórica de la sociedad, la misma que podía ser moldeada por la razón;

- la visión progresiva y en ascenso de la historia; la creencia en un final feliz de la historia;

- el rol fundamental de la ciencia y de la tecnología,

- y la creencia, de raíz judeocristiana, de una posición de dominio y poder sobre la naturaleza.

Finalmente, se sostenía la idea de la unidad intrínseca de la historia humana, es decir, la existencia de una historia universal que en la práctica se resuelve desde luego en la historia occidental. Concomitante a ella es el reconocimiento del papel desempeñado por las nociones de proceso y desarrollo, en contraste con ideas de acumulación histórica o de mera repetición cíclica. En relación con las divergencias entre ambas propuestas de la modernidad, Rosales sostiene que la primera concepción —-tomada usualmente como la posición distintiva de la Ilustración- se caracteriza por un impulso utópico, casi religioso, de reforma 
social, típico de autores como Condorcet, Hartley, Priestley y Godwin, mientras que la segunda, vinculada a los filósofos escoceses influidos sobre todo por Montesquieu, se configura en un tipo de evolucionismo sociológico más sobrio y menos utópico que el de aquellos autores. En la Ilustración continental la historia universal se visualizaría como el escenario terrenal en donde todos los problemas y tribulaciones humanos serían finalmente resueltos, esto es, la humanidad tendía a ser crecientemente percibida como el sujeto creador por antonomasia de la historia. Había en los hombres de la Ilustración continental una pasión por la razón y la justicia. Por su parte, los ilustrados escoceses tenían una visión progresiva de la historia, misma que pasaba por distintas etapas, hasta llegar a la civilización europea, pero no creían en que el progreso significaba la eliminación de los problemas humanos.

Hirschman afirma que sólo en la edad moderna, particularmente en el siglo XVIII, se difundió la idea de que el orden social inmutable podía ser la causa de la infelicidad humana, siendo, por tanto, una novedad pensar que se podía "fabricar" la felicidad cambiando el orden social. Esta idea de un orden social perfectible surgió al mismo tiempo que otra, contraria, la de los efectos no intencionados de las acciones y decisiones humanas. La primera surgió en el curso de la Ilustración francesa y la segunda fue engendrada por los moralistas escoceses de la época; esta última, subrayaba, en principio, el resultado feliz y socialmente deseable de un comportamiento ideal egoísta, que tradicionalmente se había considerado condenable, y luego destacaba que los cambios institucionales mejor intencionados podían conducir, por vía de consecuencias imprevistas o "efectos perversos" a resultados desastrosos [Hirschman, 2014: 156] ${ }^{26}$. Ambos proyectos, en

26 Hirschman, en la obra citada, hace un interesante análisis de cómo entre los siglos XVI y XVIII se fue gestando una teoría respecto de cómo las 
términos de Quijano, serían la razón histórica y la razón instrumental, respectivamente. La primera, luego de la Revolución francesa, se cristalizó en poderosas críticas al capitalismo y orientó las luchas revolucionarias y el socialismo-comunismo durante los siglos XIX y Xx [Hobsbawm, 1998a y 1998b; Carr, 1985] hasta que se desdibujó completamente por el despotismo y burocratismo de los regímenes socialistas, entre ellos, el de la desaparecida Unión de Repúblicas Socialistas Soviéticas.

Es en este marco intersubjetivo en disputa en donde puede colocarse el pensamiento de Smith; en términos de la razón instrumental, su pensamiento combinaba una teoría de la naturaleza humana y una de la historia, con una forma peculiar de teología natural (la doctrina grecoescolástica del derecho natural) y algunas observaciones prácticas de la vida económica [Silva-Herzog, 1961]. Smith, influido por su profesor Francis Hutcheson, era un seguidor de la escuela filosófica naturalista — del orden natural-, escuela que se remontaba a los últimos estoicos y epicúreos griegos, pasando por estoicos romanos como Cicerón y Séneca, y que se vio fortalecida durante el Renacimiento y la Reforma, reapareciendo con modificaciones en el pensamiento de Bacon, Hobbes y Locke, llegando a su pleno florecimiento en los escritos de Smith, de los fisiócratas y de los radicales posteriores. De manera general puede afirmarse que esta escuela de pensamiento se caracteriza por su confianza en lo natural como lo opuesto a lo inventado por el hombre, e implica, por tanto, la creencia en la existencia de un orden natural

tendencias destructivas de los seres humanos podrían ser convertidas en orientadores "positivos de la acción humana", de modo que las pasiones (poder, lujuria y búsqueda de la riqueza) podrían ser convertidas en intereses guiados por el egoísmo. Todo esto, por supuesto, sin alterar las relaciones de mando-obediencia y sin tocar los fundamentos básicos de la propiedad privada. Al respecto, ver también la interesante reflexión de Hopenhayn [1988: 90-96]. 
intrínseco superior a todo orden artificialmente creado por la humanidad, y sostiene que una organización social inteligente tiene que actuar en la mayor armonía posible con los dictados del orden natural [Roll, 1974].

El punto central de la concepción antropológica de Adam Smith era el egoísmo, visión que había desarrollado en su obra Teoría de los sentimientos morales y complementó en La riqueza de las naciones. Smith sostenía que la conducta humana se orientaría según seis elementos: autocomplacencia (self-love), simpatía, deseo de libertad, sentido de propiedad, hábito de trabajo, y propensión a cambiar unos bienes por otros. Dadas estas características básicas de la conducta, cada hombre era el mejor juez de su interés, y se le debía dejar en libertad total para seguir su camino. Ineludiblemente, utilizará su libertad en su propio interés (self-interest) y "providencialmente, la persecución del interés propio, se traducirá en la consecución del bienestar colectivo". Según la interpretación de Roll [1974], ello es así "porque la Providencia ha hecho la sociedad como un sistema donde prevalece el orden natural. Los diferentes motivos de la acción humana están tan cuidadosamente equilibrados que el beneficio de unos pocos no puede entrar en conflicto con el bienestar de los más". De ahí no hay más que un paso a la doctrina de la "mano invisible", tan cara a Smith y a algunos teóricos del libre cambio económico.

CIVILIZACIÓN, PROGRESO Y PUEBLOS SIN HISTORIA

La visión eurocéntrica de Smith planteaba un progreso evolutivo, lineal, ascendente de las sociedades en el tiempo, que tenía su fuente de cambio básica en el egoísmo: elemento invariable de la naturaleza del hombre. Según su perspectiva, la humanidad habría pasado por cuatro periodos históricos: caza, pastoreo, agricultura y comercio, definidos por el tipo de propiedad que predominó en cada uno. Siendo los tres factores clave en la evolución 
de la historia: el egoísmo, el desarrollo de los derechos de propiedad y las instituciones paralelas, y la división del trabajo. El egoísmo fue responsable de la transición de las sociedades nómadas a las agrícolas, de igual modo se desarrollaron las sociedades comerciales con el consiguiente crecimiento de las ciudades como centros comerciales. La búsqueda del beneficio propio se convirtió en el principio organizativo de la producción; "sin embargo, a lo largo del tiempo el egoísmo produce una evolución sociopolítica y un crecimiento económico importantes. La sociedad civil es en gran medida una consecuencia de la propiedad privada y de la acumulación de riqueza" [Smith, 2014: 6]. La propiedad privada y la riqueza acumulada son expresiones del egoísmo practicado. Es en la época del pastoreo cuando en la sociedad aparecen las desigualdades de riqueza, y se hace necesaria la presencia de una autoridad y la subordinación de los miembros de tal sociedad. Esta autoridad dio lugar a instituciones que reflejaron la jerarquía de la riqueza en la jerarquía del poder. De lo anterior se deriva que el egoísmo no produjo igualdad o equidad, sino sometimiento y subordinación. En otras palabras, equidad y máximo de bienestar económico social no son sinónimos en el pensamiento de Smith [Silva-Herzog, 1961].

Adam Smith tenía la convicción, compartida por el grueso de la escuela histórica escocesa (David Hume, Adam Ferguson y John Millar, entre otros), de que el mundo de la manufactura y el comercio podría traer de la mano la liberación de las energías creadoras de las personas, y de ahí, la culminación del proceso de civilización de la vida social a la que estaba orientada la evolución de la historia del hombre en sociedad. En efecto, todos estos autores utilizaban una teoría de los estadios del desarrollo de las sociedades humanas, según la cual, el mundo del comercio suponía el colofón de todo un proceso de perfeccionamiento de las formas de vida, que tuvo lugar 
mediante cuatro etapas sucesivas, que generalmente se siguen unas a otras en este orden: caza, pastoreo, agricultura y comercio. En esta dirección, Smith parece observar en todas las realidades sociales permeadas por relaciones comerciales, cuando éstas se encuentran libres del peso de cualquier forma de despotismo, la culminación de una historia natural de las sociedades caracterizada por la progresiva expansión de la civilización —de la politeness, dirá Ferguson-, definida por oposición a la rudeza de la vida en las sociedades bárbaras, civilización que no es otra cosa que la disposición, por parte de los individuos, a coadyuvar en todos los esfuerzos necesarios para la articulación y reproducción de instituciones políticas que fomenten la causa de la libertad y se dispongan a erradicar todas las formas de tiranía y dominación. Lo que en definitiva está en juego en este punto, a ojos tanto de Smith como de Ferguson, no es otra cosa que la progresiva ampliación de las libertades individuales frente al peso de los yugos, todavía vigentes, del mundo feudal, y también frente a cualquier tipo de amenaza que pueda proceder de las formas emergentes de poder económico [Roll, 1974].

Era tan marcada en Smith la visión evolucionista y del progreso, y su acendrada creencia en los logros "civilizatorios" de la industria y el comercio, como para expresar su desdén categórico por los "pueblos sin historia", "salvajes", atrasados y racialmente inferiores de América. Smith atribuyó al progreso que habría significado la introducción de la cultura europea y del comercio, la cantidad de población en México y Perú, sin reconocer el genocidio de los indígenas, en manos de los conquistadores, esclavizados para extraer los metales preciosos. Al mismo tiempo, Smith expresaba su beneplácito por la existencia de mestizos:

Antes de la conquista de los españoles no había ganado de carga en México ni en Perú. La llama era la única bestia de carga y su fuerza era muy inferior a la de un asno. No se 
conocía entre los indios el arado, ignoraban el uso del hierro, carecían de moneda acuñada u otro instrumento útil de comercio, reduciéndose éste a la permuta. El principal instrumento de que se servían en la agricultura era una especie de azada de madera; los pedernales les servían de cuchillos y hachas para cortar; con los tendones de ciertos animales y las espinas de ciertos peces confeccionaban agujas de cocer, y a esto, poco más o menos, se reducían los útiles de sus oficios. Parece absolutamente imposible que cualquiera de aquellos Imperios hubiese adelanto tanto, ni hubiera llegado a estar bien cultivo como lo vemos actualmente, si no se hubiera introducido en ellos abundancia de ganado de toda especie, el uso del hierro, el del arado y otras muchas artes de las que entonces florecían en Europa. La población en todos los países guarda proporción con los adelantos de la agricultura y de las artes industriales. A pesar de la terrible destrucción del elemento indígena que siguió a la conquista, se encuentran estos dos Imperios mucho más poblados al presente que lo que pudieron estar antes de ella. Además, la población es seguramente muy distinta, pues debemos reconocer que el elemento criollo es, en muchos aspectos, superior al indígena [Smith, 2014: 506].

En un texto reciente, Hund [2014] resalta la visión racista y colonialista que tenían los fundadores de la sociología como ciencia, entre ellos, Sieyes, Smith y Weber. Hund sostiene que, si bien Smith no utilizó la categoría raza, estableció diferencias jerárquicas a partir de argumentos culturales, estableciendo una oposición cultural entre civilizados y salvajes. Esta visión era característica de quienes integraban la escuela escocesa de filosofía moral, pues Henry Home y Lord Kames cuestionan la unidad de la humanidad y aseguran que Dios había creado diferentes especies de hombres; David Hume defendía los supuestos respecto de la supremacía cultural de la "raza" blanca, y Ferguson describía a las "razas" humanas como un siste- 
ma jerárquico natural con los "blancos" en la cima [Hund: 2014: 30]. Smith, no utilizó el concepto de raza, sino un lenguaje culturalista referido a los otros como salvajes, bárbaros o incivilizados. Según su concepción histórica asociada al progreso y a los cuatro estadios (caza, pastoreo, agricultura y comercio), los americanos, al momento en que Smith escribía, estarían en la etapa de los cazadores, los más rudos y bárbaros, mientras que las tribus germánicas durante el periodo migratorio eran más avanzadas, pues había transitado a la etapa de los pastores, lo que significaba el paso más significativo en el progreso de la sociedad, ya que por primera vez se había establecido un sistema estable de propiedad privada. Smith, no obstante, debido a su racismo cultural, no valoró de igual manera el hecho de que en África hubiera poblaciones de pastores, pues consideraba que (los hotentotes) eran una raza casi de bárbaros, como los nativos de América. Igualmente, rechazó que los nativos se encontraran en la etapa agrícola del desarrollo histórico, pues según Smith, el cultivo de maíz, denominado por él como Indian corn, había sido cultivado por las mujeres en pequeñas cantidades en terrenos ubicados detrás de sus casas, algo que difícilmente podría llamarse agricultura [Hund, 2014: 32].

EL CONCEPTO DE TRABAJO: PRODUCTIVO Y ASALARIADO, ¿Y LA HETEROGENEIDAD HISTÓRICO-ESTRUCTURAL?

En este derrotero evolutivo y "civilizatorio", la división del trabajo tendría un rol fundamental asociado al desarrollo del comercio, es decir, del intercambio. Para esto, Smith crearía una concepción de trabajo, por un lado, muy restringida a la producción material, y por otro, su visión restrictiva del trabajo productivo asociada a lo asalariado, dejando de lado otras formas de trabajo.

Smith, basado en Locke, inició la Introducción y plan de su cimera obra, La riqueza de las naciones, afirmando 
que el trabajo era el generador de riqueza, culminando así todo un esfuerzo intelectual iniciado en el siglo XVI para lograr un concepto de trabajo específico desde la perspectiva de la colonialidad-modernidad. Por tanto, Smith sostendría que se trataba de trabajo productivo, resultado de la división del trabajo, y que se registraba en las sociedades "civilizadas" o "adelantadas", las mismas que vivían del comercio. En este sentido, afirmaba que "el trabajo anual de cada nación es el fondo que en principio la provee de todas las cosas necesarias y convenientes para la vida y que anualmente consume el país. Dicho fondo se integra siempre, o con el producto inmediato del trabajo, o con lo que mediante dicho producto se compra de otras naciones" [Smith, 2014: 3].

Smith atribuyó a la división del trabajo el incremento en la productividad del trabajo: "el progreso más importante en las facultades productivas del trabajo y gran parte de la aptitud, destreza y sensatez con que éste se aplica o dirige, por doquier, parecen ser consecuencia de la división del trabajo" [Smith, 2014: 7]. Ilustraba esto a partir de su conocido ejemplo de la producción de alfileres en dos situaciones diferentes, una con una profunda división del trabajo y otra en la que esto no ocurría. En la primera, la producción de alfileres "queda dividida en dieciocho operaciones distintas, las cuales son desempeñadas en algunas fábricas por otros tantos obreros diferentes, aunque en otras un solo hombre desempeñe a veces dos o tres operaciones". En cambio, en otra "pequeña fábrica (...) que no empleaba más que diez obreros, donde, por consiguiente, algunos de ellos tenían a su cargo dos o tres operaciones (...) y podían cuando se esforzaban, hacer entre todos, diariamente, unas doce libras de alfileres (...). Por consiguiente, esas diez personas podían hacer cada día, en conjunto, más de cuarenta y ocho mil alfileres, cuya cantidad dividida entre diez, correspondía a cuatro mil ochocientos por persona. En cambio, si cada 
uno hubiera trabajado separada e independientemente, y ninguno hubiera sido entrenado en esa clase de tarea, es seguro que no hubiera podido hacer veinte o tal vez ni un solo alfiler al día [Smith, 2014: 9].

Smith sostenía que esta ampliación extraordinaria de la productividad se debía a la división del trabajo, pues ésta "en cuanto puede ser aplicada, ocasiona en todo arte un aumento proporcional en las facultades productivas del trabajo. Es de suponer que la diversificación de numerosos empleos y actividades económicas es consecuencia de esta ventaja" [Smith, 2014: 9]. Y afirmaba que la especialización era más pronunciada en los países civilizados:

esta separación se produce generalmente con más amplitud en aquellos países que han alcanzado un nivel más alto de laboriosidad y progreso, pues generalmente es obra de muchos, en una sociedad culta, lo que hace uno solo, en estado de atraso. En todo país adelantado, el labrador no es más que labriego y el artesano no es sino menestral. Asimismo, el trabajo necesario para producir un producto acabado se reparte, por regla general, entre muchas manos. ¿Cuántos y cuán diferentes oficios no se advierten en cada ramo de las manufacturas de lino y lana, desde los que cultivan aquella planta o cuidan el vellón hasta los bataneros y blanqueadores, aprestadores y tintoreros? [Smith, 2014: 9].

La elevada productividad, consecuencia de la división del trabajo, obedecía a la mayor destreza de cada obrero en particular, al ahorro de tiempo del que comúnmente se perdía al pasar de una ocupación a otra, y por último, a la invención de un gran número de máquinas que facilitaban y abreviaban el trabajo, capacitando a un hombre para hacer la labor de muchos [Smith, 2014: 11] $]^{27}$.

27 Este punto daría lugar a una reflexión respecto de la alienación en el trabajo, como se verá en un apartado posterior. 
Smith atribuyó la división del trabajo a la inclinación humana a intercambiar, lo que requería la cooperación, no por benevolencia o solidaridad, sino por una motivación egoísta que busca un beneficio individual. Por tanto, la división del trabajo es "la consecuencia gradual, necesaria aunque lenta, de una cierta propensión de la naturaleza humana que no aspira a una utilidad tan grande: la propensión a permutar, cambiar y negociar una cosa por otra" [Smith, 2014: 16].

Sostenía que el hombre, a diferencia de los animales:

reclama en la mayor parte de las circunstancias la ayuda de sus semejantes (...) y (...) una sociedad civilizada necesita a cada instante la cooperación y asistencia de la multitud (...) pero en vano puede esperarla sólo de su benevolencia. La conseguirá con mayor seguridad interesando en su favor el egoísmo de los otros y haciéndoles ver que es ventajoso para ellos hacer lo que les pide (...) Quien propone un trato a otro le dice "dame lo que necesito y tendrás lo que deseas", es el sentido de cualquier clase de oferta, y así obtenemos de los demás la mayor parte de los servicios que necesitamos [Smith, 2014: 17].

En esta línea de reflexión, Smith sostendría que no hay solidaridad en las relaciones de intercambio, sólo egoísmo, al afirmar que:

no es la benevolencia del carnicero, del cervecero o del panadero la que nos procura el alimento, sino la consideración de su propio interés. No invocamos sus sentimientos humanitarios sino su egoísmo; ni les hablamos de nuestras necesidades, sino de sus ventajas (...) De la misma manera que recibimos la mayor parte de los servicios que necesitamos, por convenio, trueque o compra, es esa misma inclinación a la permuta la causa originara de la división del trabajo [Smith, 2014: 17]. 
En relación con el trabajo como valor de uso y valor de cambio, Smith sostendría que el valor de una mercancía en las sociedades civilizadas estaría dado por los factores que participan en su producción. Esto se alejaba de lo que ocurría en las sociedades primitivas, en las que el cambio recíproco estaría regulado por la cantidad de trabajo necesario para adquirir cada producto: la cantidad de trabajo era la única norma de valor, la que consideraba las diferencias en el esfuerzo requerido y en la destreza e ingenio. Al mismo tiempo, el producto íntegro del trabajo pertenecía al trabajador. Pero en una sociedad civilizada, comercial, en la que:

el capital se acumula en poder de personas determinadas, algunas de ellas procuran emplearse en dar trabajo a gentes laboriosas, suministrándoles materiales y alimentos, para sacar provecho de la venta de su producto o del valor que el trabajo incorpora a los materiales. Al cambiar un producto acabado, bien sea por dinero, bien por trabajo, o por otras mercaderías, además de lo que sea suficiente para pagar el valor de los materiales y los salarios de los obreros, es necesario que se dé algo por razón de las ganancias que corresponden al empresario, el cual compromete su capital en esa contingencia. En nuestro ejemplo el valor que el trabajador añade a los materiales se resuelve en dos partes: una de ellas paga el salario de los obreros y la otra las ganancias del empresario, sobre el fondo entero de materiales y salarios que adelanta [Smith, 2014: 48].

Si la tierra se privatiza, el propietario debía recibir una renta por el uso de la tierra, factor que se "halla en el precio de la mayor parte de los artículos como un tercer componente" [Smith, 2014: 49]. Así, "en toda sociedad, pues, el precio de cualquier mercancía se resuelve en una $\mathrm{u}$ otra de esas partes, en las tres a un tiempo, y en todo pueblo civilizado las tres entran, en mayor o menor grado, 
en el precio de casi todos los bienes" [Smith, 2014: 49]. Por tanto, "salarios, beneficio y renta son las tres fuentes originarias de toda clase de renta (N. del A.: en el sentido de ingreso) y de todo valor de cambio [Smith, 2014: 51-52].

TRABAJO PRODUCTIVO E IMPRODUCTIVO, ECONOMICISMO

Y CLASIFICACIÓN SOCIAL

La escuela mercantilista había planteado una diferenciación entre trabajo productivo e improductivo a partir de la afirmación de que sólo la agricultura (la tierra) generaba un producto neto por encima de los costos implicados en el proceso productivo. Los fisiócratas sostenían que las manufacturas y el comercio no creaban riqueza. Genovesi, por su parte, como se vio en el apartado anterior, había planteado que el trabajo productivo se concentraba en las artes primarias y secundarias, considerando la agricultura, la pesca, la transformación y el comercio. En cambio, según Hobsbawm [1998a], Smith, identificándose con la burguesía emergente, igualaría el trabajo productivo con el manufacturero, legitimando de este modo la hasta entonces condenada búsqueda de la ganancia a partir de una conducta egoísta.

Smith plantearía una definición excluyente del trabajo productivo hacia lo social y cultural. Para tener claridad en este asunto, Valenzuela Feijóo [1977], sostiene que es importante establecer que la idea de riqueza en Smith tendría cuatro rasgos: $a$ ) poseer un valor de uso, $b$ ) ser mercancías, es decir, un valor de cambio, $c$ ) ser mercancías producidas en forma capitalista, de modo que en su valor esté ya incluido el beneficio o plusvalía capitalista, y d) que tales mercancías sean productos corpóreos, físicamente palpables; es decir, que sean bienes materiales. Por tanto, se entiende como riqueza a los objetos que tienen valor de cambio [Valenzuela Feijóo, 1977]. Así, Smith afirmaba que "existe una especie de trabajo que añade valor al 
objeto al que se incorpora, y otra que no produce aquel efecto. Al primero, por el hecho de producir valor, se le llama productivo; al segundo, improductivo" [Smith, 2014: 299]. En este sentido, el trabajo productivo es el que crea riqueza en productos que tienen valor de uso, a partir de la relación capital-trabajo y que añade un valor adicional al salario y la ganancia del patrón. "Así, el trabajo de un artesano en una manufactura, agrega generalmente valor a los materiales que trabaja, tales como su mantenimiento y los beneficios del maestro (...) por el contrario (...) el de un criado doméstico (...) no añade valor alguno". El trabajo productivo tiene que incorporarse en una mercancía vendible, es decir, que tenga valor de cambio: "la labor del obrero empleado en las manufacturas se concreta y realiza en algún objeto especial o mercancía vendible, que dura, por lo menos algún tiempo después de terminado el trabajo. Viene a ser como si en aquella mercancía se incorporase o almacenase una cierta cantidad de trabajo, que se puede emplear, si es necesario, en otra ocasión". Por el contrario, "el trabajo de los servidores domésticos no se concreta ni realiza en materia alguna particular o mercancía susceptible de venta. Sus servicios perecen, por lo común, en el momento de prestarlos y rara vez dejan tras de sí huella de su valor, que sirviera para adquirir igual cantidad de trabajo" [Smith, 2014: 299-300].

Con esta definición del trabajo productivo e improductivo, Smith, por un lado, estableció un criterio eurocéntrico para legitimar cierto tipo de trabajo en un sentido universal, pues al identificar el trabajo productivo sólo con el trabajo asalariado, dejó de lado otras formas de trabajo no asalariadas y otras formas de trabajo que no tenían una concreción material. Finalmente, dada su concepción naturalista de la sociedad y de las relaciones de mando y obediencia, el identificar que las clases gobernantes eran improductivas no se concretó en una crítica de tal situación. Esto es, no cuestionó las relaciones de dominación 
y explotación existentes, porque su concepción del mundo era naturalista y basada en la razón instrumental.

Smith consideraba como esencia de la riqueza la producción de bienes físicos solamente, calificando como improductivos los bienes intangibles o servicios, tal era el caso de los artistas y los docentes. Con ello, Smith sólo hacía hincapié en la dimensión objetiva del trabajo (lo que éste produce) y no en su dimensión subjetiva (quién produce, quién trabaja), dimensión que también tienen los demás factores de la producción. Por ello, los salarios también se determinan de acuerdo con las leyes del mercado, como si se tratara de cualquier otro bien [Silva-Herzog, 1961]. Smith equiparaba como improductivos todos los trabajos que no se reflejaran en la producción de bienes físicos, desechando todos aquellos trabajos, más allá de su honorabilidad o utilidad, que "nada producen en el sentido de poder adquirir igual cantidad de otro servicio" [2014: 300], esto es, que no tienen valor de cambio. En esta clasificación como trabajos improductivos incluyó a quienes llevaban a cabo distintas actividades en los ámbitos educativo, cultural y de salud, entre otros, así como a las labores propias del aparato estatal, por ejemplo, las de defensa de la república. Así, Smith afirmaba que "el trabajo de algunas de las clases más respetables de la sociedad, al igual que lo que ocurre con los servidores domésticos, no produce valor alguno, y no se concreta o realiza en un objeto permanente o mercancía vendible, que dure después de realizado el trabajo, ni da origen a valor que permitiera conseguir más tarde igual cantidad de trabajo" [Smith, 2014: 300]. Smith incluye a todo el aparato estatal: "el soberano, por ejemplo, con todos los funcionarios o ministros de justicia que sirven bajo su mando, los del ejército y la marina, son en ese sentido, trabajadores improductivos. Sirven al público y se les mantiene con una parte del producto anual de los afanes de las demás clases del pueblo" pues "la protección, la seguridad y la 
defensa de la república, efecto del trabajo de esos grupos en el presente año, no podrá comprar la defensa, la protección y la seguridad en el venidero", al afirmar que "igual consideración merecen otras muchas profesiones, tanto de las más importantes y graves como de las más inútiles y frívolas, los jurisconsultos, los clérigos, los médicos, los literatos de todas clases; y los bufones, músicos, cantantes, bailarines, etc." [Smith, 2014: 300].

Smith desecharía estos trabajos de la categoría de productivos porque no generan valores de cambio: "el trabajo de los más insignificantes" y "aun el de la clase más noble y útil, nada produce que sea capaz de proporcionar, después, otra cantidad de trabajo igual, porque perece en el momento mismo de su prestación, como la declamación del actor, la arenga del orador o la melodía del músico" [Smith, 2014: 300].

\section{EL TRABAJO PRODUCTIVO, UNA VISIÓN EUROCÉNTRICA}

ECONOMICISTA Y EXCLUYENTE DEL TRABAJO

Desde su mirada evolutiva y civilizatoria eurocéntrica, Smith estableció que los acelerados cambios que experimentaba la sociedad inglesa debían ser los de todo el continente europeo, Estados Unidos de América, y en general, el mundo entero: la industrialización y la generalización del trabajo asalariado. Esta visión no tenía en cuenta la heterogeneidad histórico-estructural de las sociedades y la idea de capitalismo como estructura de explotación social a partir del control de la mano de obra por el capital, que subordina a otras formas de control del trabajo (asalariado, esclavitud, servidumbre, reciprocidad y producción mercantil simple) que coexisten y no son anteriores ni se extinguen con la expansión del trabajo asalariado, desde una perspectiva espacio-temporal mundial, como ya se comentó en la introducción de este texto. En la Inglaterra de fines del siglo XIX, un siglo después 
de la publicación de La riqueza de las naciones, y según Palmade [1976: 134], si bien los artesanos y obreros eran la mayoría en términos cuantitativos, entre los diversos estratos socioprofesionales, la presencia de otros estratos dominados no era desdeñable: los propietarios de tierras no nobles, los campesinos propietarios de tierras no nobles, los arrendatarios, los campesinos, los braceros y los vagabundos. Por su parte Wallerstein [2011] afirma que a finales del siglo xv y principios del XvI, nació una economía mundoeuropea conformada por el centro, semiperiferia y periferia, y basada en el modo de producción capitalista. Esta economía-mundo estaba conformada por el noroeste de Europa y el mediterráneo cristiano, Europa central y la región báltica; ciertas regiones de las Américas: Nueva España (México), las Antillas, Perú, Chile y Brasil, o sea, las partes de estas regiones que estaban sometidas a un control administrativo efectivo por parte de España y Portugal. Las colonias americanas tuvieron un rol decisivo en el paso del capitalismo comercial al industrial, pues los metales preciosos enviados a Europa (oro y plata) contribuyeron al abaratamiento del costo del dinero, a la inflación de precios y redistribución del ingreso, al descenso real de los salarios y posibilitaron la creación de un fondo de acumulación de capital. La inclusión de Europa Oriental y la América española en una economía-mundo europea, durante el siglo xvi no sólo proporcionó capital (gracias a los botines y altos márgenes de ganancia), sino que también liberó mano de obra en las áreas del centro para su especialización en otras labores. $\mathrm{El}$ abanico ocupacional en las áreas centrales era muy complejo, incluía un gran remanente paralelo a los de la periferia (producción de grano), pero la tendencia en el centro era hacia la variedad y la especialización, mientras que la tendencia en la periferia era hacia el monocultivo. La periferia (Europa oriental y la América española) utilizaba trabajo forzado (esclavitud y trabajo obligado en 
cultivos para el mercado), el centro utilizaba cada vez más trabajo libre; la semiperiferia (antiguas áreas centrales en camino hacia estructuras periféricas) desarrolló la aparcería. Así, la economía-mundo de esa época tenía varios tipos de trabajadores:

a) Esclavos que trabajaban en las plantaciones de azúcar y en operaciones mineras de excavación en la superficie.

b) Siervos, que se encontraban en grandes dominios donde se cultivaban granos y se producía madera.

c) Granjeros arrendatarios (tenants), dedicados a varios tipos de cultivos (además de los granos).

d) Trabajadores asalariados (constituían 95\% de la población de la economía-mundo europea).

e) Un reducido segmento de campesinos libres (yeomen).

f) Un pequeño grupo de personal intermedio (capataces y artesanos independientes) y algunos trabajadores especializados.

Las clases dominantes se ocupaban de supervisar las grandes propiedades, se hacían cargo de las instituciones fundamentales del orden social, en alguna medida, dedicadas a su propio disfrute (nobleza, burguesía, clero cristiano y burocracia estatal). Estas categorías no estaban distribuidas al azar, ni geográfica ni étnicamente, en el seno de la floreciente economía-mundo europea: una clase esclava de orígenes africanos; en América Latina, una clase servil dividida en dos segmentos: uno principal en Europa oriental y otro menor de indios americanos en el hemisferio occidental. Los campesinos de la Europa occidental y meridional eran en su mayor parte arrendatarios. Los trabajadores asalariados eran prácticamente en su totalidad europeos occidentales. Los yeomen estaban en gran medida concentrados en el noroeste de Europa. Las clases 
intermedias eran de origen paneuropeo (más mestizos y mulatos) y estaban distribuidos geográficamente por toda la arena. Las clases dominantes eran también de origen paneuropeo, sobre todo de Europa occidental. Wallerstein se pregunta: ¿por qué hay diferentes modos de organizar el trabajo, esclavitud, feudalismo (servidumbre), trabajo asalariado y autoempleo en el mismo punto temporal en el seno de la economía-mundo? Porque cada tipo de control del trabajo es el más adecuado para tipos particulares de producción. ¿Por qué estaban concentrados estos modos en diferentes zonas de la economía-mundo (la esclavitud y el feudalismo en la periferia, el trabajo asalariado y el autoempleo en el centro y la aparcería en la semiperiferia)? Porque los modos de control del trabajo afectaban al sistema político (particularmente a la fuerza del Estado) y a las posibilidades de florecimiento de una burguesía indígena. Así, la economía-mundo europea estaba basada en el supuesto de que existían tres zonas (centro, semiperiferia y periferia) con diferentes modos de control del trabajo. Esto hizo posible garantizar el flujo de excedente que permitió la aparición del sistema capitalista.

\section{LA SUBORDINACIÓN Y EL DESPRECIO}

DEL TRABAJO MANUAL

Smith, a partir de las nociones eurocéntricas de civilización y progreso, sostendría que las sociedades con mayor división del trabajo y comercio serían las más acabadas dentro de un devenir histórico evolutivo. Como ya se señaló, plantearía que la acción humana se basa en el egoísmo y el individualismo, sosteniendo que la búsqueda individual de utilidad resultaría beneficiosa para la sociedad en su conjunto, por lo cual sería contraproducente la intervención del Estado en la economía. En este sentido, Smith fue el punto de culminación de una concepción utilitarista de la acción humana y una clara expresión 
de la razón instrumental que había sido elaborada por la Ilustración escocesa.

En relación con el trabajo, Smith estableció un concepto central para la economía política, asociado a lo manual-productivo-creador de valor-asalariado. Al mismo tiempo, sancionó una concepción de valor que tenía sobre la base una desvinculación de la producción de su medio material-natural, al sostener que el valor de cambio estaba relacionado con el tiempo de trabajo socialmente necesario para producir mercancías, en relación con un tiempo abstracto, desvinculado de los valores de uso que encarnaban tales mercancías. Por tanto, planteó que el valor se determinaba como resultado de una relación social medida: el trabajo temporalmente medido, es productor de valor.

Adam Smith representa el punto de inflexión en la consideración del trabajo. Su teoría rompe con lo que hasta entonces se pensaba como trabajo, que deja de ser un posible productor de materia para convertirse en productor de valor, categoría eminentemente social, pues sólo se concibe como fruto de relaciones entre individuos. Para Smith, el trabajo es la medida de todas las cosas, pues cualquier objeto intercambiado contiene trabajo, y la cantidad de trabajo (esfuerzo) que un objeto posee es lo que le da valor; pero para convertirlo en valor es preciso establecer una medida: el tiempo, que es la esencia del trabajo. Así, cualquier objeto sencillo o complejo puede descomponerse en unidades de trabajo sencillas; de ese modo, puede calcularse lo que vale el bien que se quiere intercambiar, y en consecuencia, el trabajo se convierte en una abstracción, y es esa sustancia a la que se reduce todo objeto y que da lugar al intercambio. De este modo, el trabajo es un elemento instrumental para crear valor y el trabajo es simplemente lo que genera riqueza. Como en el siglo XviII el concepto de riqueza era muy restringido (referido a la producción), el concepto de trabajo también 
era restringido: trabajo productivo, es decir, trabajo sobre objetos materiales. El trabajo, en la medida en que tiene un precio, es también una mercancía y está sujeta a compraventa [Ibáñez, 2002: 160-164].

Esta concepción del trabajo, como se ha manifestado ya, ignora la heterogeneidad histórico-estructural de las sociedades y deja de lado otras formas de trabajo, entre ellas la esclavitud, la servidumbre, la pequeña producción mercantil simple y el trabajo doméstico.

Este concepto de trabajo centrado en lo económico productivo ha sido secularizado y despojado de toda virtud y eticidad, para ser gobernado por el egoísmo y el utilitarismo. El trabajo ya no está vinculado a la virtud, sino a lo útil, a lo eficiente, a la racionalidad instrumental. Había aquí, como dice Hopenhayn, otra vez, como al final de la Edad media, una nueva ambigüedad:

respecto del trabajo endiosado y cosificado (...) que es esencial para entender y justificar, al extenderse la revolución industrial, el trabajo masivo y despersonalizante de las fábricas modernas y de la producción en gran escala. Era preciso endiosar el trabajo porque era preciso sacarle el máximo provecho a la fuerza de trabajo en las nuevas fuentes productivas, pero también era necesario cosificarlo, reducirlo a mera fuerza de trabajo, convertirlo en una actividad abstracta, cuantificable e instrumental, para adaptar la idea de trabajo a la modalidad de la producción masiva de las plantas industriales [Hopenhayn, 1988: 96].

Así, con Smith se constituyó la economía política clásica que reducía al hombre a su condición de trabajador, pero a su vez reduce al trabajador a la racionalidad autónoma del mercado, "la mano invisible". Separada de la ética, esta supuesta ciencia positiva que es la economía echa tierra sobre el concepto de trabajo sedimentado en la tradición religiosa o el humanismo laico; será preciso que la filosofía 
alemana del siglo xIx, primero Hegel, luego Marx, le asigne al trabajo un nuevo sentido [Hopenhayn,1888: 99].

Finalmente, este concepto de trabajo endiosado y cosificado, encerraba, además, otra contradicción, pues el trabajo manual, el creador de riqueza, nunca dejó de ser considerado despreciable por las clases dominantes que tenían un sedimento aristocrático, que miraba con desdén el trabajo manual; una visión que tenía por lo menos unos dos mil años de existencia.

La exaltación del trabajo que fue engendrándose entre los siglos XVI y XIX, no tuvo efecto en la clasificación social y las relaciones de mando-obediencia características de las sociedades clasistas, en las que raza y sexo también están presentes, en tanto interseccionalidad entre los tres elementos como definitorios de la asignación de la distribución de las personas en las relaciones de poder en la sociedad capitalista.

En la sociedad aristocrática del antiguo régimen, el derecho tradicional distinguía tres órdenes o estados, el clero, la nobleza (estamentos privilegiados), y el que comprendía la inmensa mayoría de la nación. El origen de los estamentos se remontaba a la Edad Media, en donde se hacía patente la diferencia entre quienes rezaban, combatían y los que trabajaban para que vivieran los demás. El estamento del clero era el más antiguo, tuvo desde un principio una condición especial regida por el derecho canónico. Más tarde, se hizo necesario entre los laicos el grupo social de la nobleza. Quienes no eran ni clérigos ni nobles constituían la categoría de artesanos, que dio lugar al nacimiento del tercer estado. Los estamentos no constituían clases sociales en sí, cada uno estaba dividido en grupos más o menos antagónicos. Sobre todo, la antigua estructura social fundada en el sistema feudal, el desprecio por las actividades manuales y las ocupaciones productoras, no estaban en absoluto en armonía con la realidad [Saboul: s/f]. 
No era sólo el interés lo que guiaba a la burguesía; sin duda su conciencia de clase se había robustecido por el exclusivismo de la nobleza y por el contraste entre su elevación económica e intelectual y su regresión civil, pero consciente de su poder y su valor, y habiendo recibido de los filósofos una cierta concepción del mundo y una cultura desinteresada, la burguesía no solamente estimaba como cosa suya transformar el antiguo régimen, sino que creía justo hacerlo. Estaba persuadida de que existía un cierto acuerdo entre sus intereses y la razón. Mas debemos matizar estas afirmaciones, la burguesía era muy diversa, no constituía una clase homogénea; muchos burgueses no se conmovieron ante la propaganda filosófica, otros eran francamente hostiles al cambio, bien por religiosidad, bien por tradicionalismo (entre las víctimas del Terror hubo una gran mayoría de personas pertenecientes al tercer estado). Si deseaba los cambios y las reformas, la burguesía no tenía ni la menor idea de una revolución. El tercer estado, en general, sentía una gran veneración por el rey, un sentimiento casi de carácter religioso. Como testimonio tenemos a Marmont con sus Mémoires, el rey representaba la idea nacional y nadie pensaba en acabar con la monarquía. La burguesía pretendía menos destruir a la aristocracia que fundirse con ella, la alta burguesía en especial; su simpatía extrema por La Fayette fue significativa en este aspecto. Por último, la burguesía estaba muy lejos de ser democrática. Pretendía conservar una jerarquía social, distinguirse de las clases que estaban por debajo de ella. Nada estaba tan determinado, según Cournot en su Souvenirs, como la subordinación de las clases en esta sociedad burguesa. A la mujer del procurador o del notario se la llamaba mademoiselle, a la del consejero, madame, sin discusión. Desprecio de la nobleza por los campesinos, desprecio de la burguesía por las clases populares, este prejuicio de clase explica la cólera y el miedo de la burguesía cuando recurrió a las clases populares 
contra la aristocracia y vio que en el año II pretendían el poder [Saboul, s/f: 30-31].

El inglés tiene la religión de la desigualdad, afirmaba Gladstone. No cabe duda de que ese país, modelo de desarrollo capitalista en la época liberal, no sólo conserva, sino que acentúa incluso las viejas distinciones jerárquicas. Una barrera separa a aquéllos considerados "respetables" de los que no lo son. La gente respetable, de la pequeña burguesía a los Pares del reino, admite un código en el que se funden antiguos valores aristocráticos y nuevas virtudes burguesas. Los demás quedan excluidos y no participan en la vida en la que se reconocen las élites: son los trabajadores manuales. Dentro de esas dos grandes clases, mil signos distintivos, símbolos y comportamientos separan a los grupos secundarios [Palmade, 1976: 135].

En la segunda mitad del siglo XIX, cuando el trabajo asalariado y la civilización industrial "conquistaban el mundo”, era claro que la situación de mando-obediencia vertical no se había alterado:

Aunque responden a formas de trabajo extremadamente variadas, las clases dirigentes tienen en común ciertos privilegios y un mismo modo de vida. Estos privilegios son tres: la propiedad, la enseñanza y el poder. La propiedad, porque clase rectora es sinónimo de clase poseedora: en un sistema de propiedad privada de los medios de producción, son quienes detentan capitales, minas, fábricas, tierras, los que imponen su dirección y su voluntad a aquellos a quienes emplean; son ellos los que orientan la vida económica y el trabajo, aun cuando esta propiedad se encuentre fraccionada entre cierto número de accionistas. La instrucción, decíamos, porque aun cuando la enseñanza elemental se ha generalizado para las masas, son los muchachos pertenecientes a las "clases superiores" 
los que siguen ocupando, en arrolladora proporción, las aulas de liceos y centros de enseñanza media, las Grandes Écoles, los institutos superiores y las universidades. El poder, por último, porque el Estado se encuentra entre las manos de las clases dirigentes en cuestión. De sus filas salen el personal político y los miembros de las asambleas parlamentarias, los altos funcionarios y los mandos de la administración civil. Poder político y poder económico están estrechamente vinculados por lazos personales y familiares, amistades de colegio y de club [Fohlen y Bédarida, 1965].

Al menos los nobles tenían la conciencia de su dignidad así como la de la indignidad que pesaba sobre sus esclavos. El desprecio aristocrático del trabajo reflejaba el desprecio del amo respecto de las clases dominadas; el trabajo era la expiación a la cual les condenaba desde toda la eternidad el decreto divino que había querido que fueran, por razones impenetrables, inferiores. El trabajo se inscribía entre las sanciones de la Providencia como el castigo del pobre y, como regulaba así la salvación futura, un tal castigo podía revestirse con los atributos de la alegría. En el fondo, el trabajo importaba menos que la sumisión [Vaneigen, 1995: 65].

\subsubsection{MARX: CRÍTICA RADICAL AL CAPITALISMO Y TENSIONES EUROCÉNTRICAS}

En este apartado se presentan las principales ideas de Marx respecto del trabajo, en tanto el mayor crítico radical del capitalismo en el siglo XIX, quien logró desnaturalizar los mecanismos de la dominación y explotación capitalista; pese a ello, la crítica de Marx no logró ser alternativa a la concepción del mundo de la modernidad capitalista, porque él, si bien cuestionaba los aspectos negativos del capitalismo en torno al trabajo, tenía una visión positiva de lo progresivo del capitalismo, sostenía 
que el desarrollo de este era inexorable. En este sentido, la limitación de la crítica marxista al capitalismo radica en que Marx compartía los valores centrales de la civilización occidental: desarrollo, progreso, industrialización, trabajo asalariado y desarrollo tecnológico homogeneizando el globo y destruyendo culturas "atrasadas" o "pueblos sin historia".

En esta visión, fuertemente marcada por la homogeneización social que debía ocurrir con el avance del capitalismo, no había cabida para experiencias históricas no capitalistas, caracterizadas por racionalidades solidarias, el trabajo colectivo, relaciones de complementariedad entre las personas y la naturaleza, como era el caso de los modos de vida campesino-indígena. En la concepción de Marx no había cabida para la simultaneidad o la copresencia o simultaneidad de estructuras histórico-sociales, de tiempos y espacios diferentes, sino de manera transicional, ya que las estructuras no capitalistas serían eliminadas por la creciente e indetenible difusión de las relaciones asalariadas; esto es, en el análisis de Marx no había cabida para la heterogeneidad histórico-estructural.

Su crítica a la economía política se basó en conceptos que habían sido creados por el pensamiento dominante y que no dejaban ningún espacio legítimo para otras prácticas económicas (el trabajo colectivo basado en la reciprocidad y en la propiedad colectiva de los recursos de producción), no únicamente como una manera de satisfacer las necesidades básicas, sino como la reproducción de la vida, humana y no humana en su conjunto ${ }^{28}$. Todo esto era "atrasado", "arcaico" y debía desaparecer con el impulso transformador y revolucionario del capitalismo. Cuando puso en cuestión su visión evolucionista, al evaluar las posibilidades del paso de la Rusia agraria con productores en su mayoría campesinos y organizados

${ }^{28}$ Este aspecto se discute en la parte 3 del libro. 
colectivamente, entrevió la posibilidad de saltar la etapa capitalista para llegar al comunismo. Esta posibilidad de transformación revolucionaria, sin embargo, sería una excepción en un mundo ancho y ajeno en el que lo no capitalista era una mayoría abrumadora, en términos de población implicada.

En relación al concepto de trabajo de Marx, primero se desplegarán unas de sus más importantes contribuciones, y después se discutirán algunas tensiones eurocéntricas inherentes en su obra. Entre algunos de los aportes de Marx acerca del trabajo destacan el develamiento de los mecanismos de la explotación y la crítica a la alienación capitalista. Respecto de las tensiones eurocéntricas, son relevantes la adhesión de Marx a las ideas de civilización y progreso, y al cientificismo liberal (la ciencia positiva), así como a las dualidades dialécticas en las cuales se sustenta su análisis del capitalismo.

Los aportes de Marx respecto del trabajo

TRABAJO Y FUERZA DE TRABAJO: EL DESENTRAÑAMIENTO

DE LA EXPLOTACIÓN

Para Marx, el trabajo es, en primer lugar:

un proceso entre el hombre y la naturaleza, un proceso en que el hombre media, regula y controla su metabolismo con la naturaleza. El hombre se enfrenta a la materia natural misma como un poder natural. Pone en movimiento las fuerzas naturales que pertenecen a su corporeidad, brazos y piernas, cabeza y manos, a fin de apoderarse de los materiales de la naturaleza bajo una forma útil para su propia vida. $\mathrm{Al}$ operar por medio de ese movimiento sobre la naturaleza exterior a él y transformarla, transforma a la vez su propia naturaleza. Desarrolla las potencias que dormitaban en ella 
y sujeta a su señorío el juego de fuerzas de la misma [Marx, 1982, t. I, vol. I: 215-216].

El trabajo es, en segundo lugar, una acción que se lleva a cabo concibiendo todo lo que implica mentalmente, como establece al comparar la acción de las abejas en la colmena con la acción humana, afirmando que:

concebimos el trabajo bajo una forma en la cual pertenece exclusivamente al hombre. Una araña ejecuta operaciones que recuerdan las del tejedor, y una abeja avergonzaría, por la construcción de las celdillas de su panal, a más de un maestro albañil. Pero lo que distingue ventajosamente al peor maestro albañil de la mejor abeja es que el primero ha modelado la celdilla en su cabeza antes de construirla en la cera. $\mathrm{Al}$ consumarse el proceso de trabajo surge un resultado que antes del comienzo de aquél ya existía en la imaginación del obrero, o sea idealmente [Marx, 1982, t. I, vol. I: 215-216].

Finalmente, Marx destaca, en tercer lugar, que el trabajo es una voluntad orientada hacia un fin:

El obrero no sólo efectúa un cambio de forma de lo natural; en lo natural, al mismo tiempo, efectiviza su propio objetivo, objetivo que él sabe que determina, como una ley, el modo y manera de su accionar y al que tiene que subordinar su voluntad, y esta subordinación no es un acto aislado. Además de esforzar los órganos que trabajan, se requiere del obrero, durante todo el transcurso del trabajo, la voluntad orientada a un fin, la cual se manifiesta como atención. Y tanto más se requiere esa atención cuanto menos atrayente sea para el obrero dicho trabajo, por su propio contenido y la forma y manera de su ejecución; cuanto menos, pues, disfrute el obrero de dicho trabajo como de un juego de sus propias fuerzas físicas y espirituales [Marx, 1982, t. I, vol. I: 215-216]. 
Marx entendía por fuerza de trabajo o capacidad de trabajo: "el conjunto de las facultades físicas y mentales que existen en la corporeidad, en la personalidad viva de un ser humano y que él pone en movimiento cuando produce valores de uso de cualquier índole" [Marx: 1982, t. I, vol. I: 203].

Marx develó el mecanismo que permitía la generación del plusvalor y la explotación a partir del análisis del consumo de la fuerza de trabajo en el proceso productivo, pues desde la esfera de la circulación, lo que había era un intercambio de equivalentes entre comprador y vendedor de dinero. Por tanto, el proceso de generación de plusvalor era al mismo tiempo el proceso de transformación de dinero en capital. Para esto, la fuerza de trabajo debía ser ofrecida como mercancía, y era necesario que el poseedor fuera propietario libre de su capacidad de trabajo, de su persona:

Él y el poseedor de dinero se encuentran en el mercado y traban relaciones mutuas en calidad de poseedores de mercancías dotados de los mismos derechos, y que sólo se distinguen por ser el uno vendedor y el otro comprador; ambos son, pues, jurídicamente iguales. Para que perdure esta relación es necesario que el poseedor de la fuerza de trabajo la venda siempre por un tiempo determinado; y nada más, ya que, si la vende toda junta, de una vez para siempre, se vende a sí mismo, se transforma de hombre libre en esclavo, de poseedor de mercancía en simple mercancía [Marx, 1982, t. I, vol. I: 204].

La fuerza de trabajo es, pues, una mercancía peculiar que, como todas las demás mercancías, tiene un valor, el mismo que "se determina por el tiempo de trabajo necesario para su producción" esto es, "el valor de la fuerza de trabajo es el valor de los medios de subsistencia necesarios para la conservación del poseedor de aquélla" [Marx, 1982, t. I, vol. I: 207]. El valor de la fuerza de trabajo 
debía incluir la reposición del gasto energético en cada jornada de trabajo, considerando las necesidades imprescindibles (alimentación, vestido y vivienda, entre otras), las mismas que tenían un elemento histórico y moral; la reposición generacional de la fuerza de trabajo, es decir la suma de los medios de subsistencia necesarios para la producción de la fuerza de trabajo futura, de los hijos de los obreros, y por último, los costos de formación o educación de los trabajadores. Por tanto, "el valor de la fuerza de trabajo se resuelve en el valor de determinada suma de medios de subsistencia" [Marx, 1982, t. I, vol. I: 209]. ${ }^{29}$

Marx plantearía que el misterio de la generación del valor no se agotaba en la compra por parte del capitalista de la fuerza de trabajo; esto es, había una diferencia entre la fuerza de trabajo potencial y la fuerza de trabajo efectiva. La clave era el consumo del valor de uso de la fuerza de trabajo. Así, sostenía que: "conocemos ahora el modo en que se determina el valor que el poseedor de dinero le paga a quien posee esa mercancía peculiar, la fuerza de trabajo. El valor de uso que, por su parte, obtiene el primero en el intercambio, no se revelará sino en el consumo efectivo, en el proceso de consumo de la fuerza de trabajo". Este es "al mismo tiempo el proceso de producción de la mercancía y del plusvalor. El consumo de la fuerza de trabajo, al igual que el de cualquier otra mercancía, se efectúa fuera del mercado o de la esfera de la circulación" [Marx, 1982, t. I, vol. I: 213].

Había que pasar a la "oculta sede la producción. (...) Veremos aquí no sólo como el capital produce, sino también como se produce el capital. Se hará luz, finalmente,

29 Ver la crítica de Federici [2013, cap. 9] a Marx respecto a la ausencia en su análisis de la reproducción de la fuerza de trabajo, y del trabajo reproductivo de las mujeres, es decir, del trabajo doméstico, el trabajo de producir y reproducir la fuerza de trabajo. 
sobre el misterio que envuelve la producción de plusvalor" [Marx, 1982, t. I, vol. I: 214].

$\mathrm{Al}$ momento de usar la fuerza de trabajo, se pasa del trabajo potencial al trabajo efectivo, pues el comprador de la fuerza de trabajo la consume, haciendo trabajar a su vendedor. Así, este último "llega a ser actu (efectivamente) lo que antes era sólo potentia (potencialmente): fuerza de trabajo que se pone en sí misma, obrero. Para representar su trabajo en mercancías, debe ante todo representarlos en valores de uso; en cosas que sirvan para la satisfacción de las necesidades de cualquier índole [Marx,1982, t. I, vol. I: 215]. Una vez que el comprador de la fuerza de trabajo ha adquirido en el mercado todos los factores necesarios para efectuar un proceso laboral (factores objetivos-medios de producción y el factor subjetivo o fuerza de trabajo), este comprador se va convirtiendo en capitalista en la medida en que consume la fuerza de trabajo comprada. Marx remarcaría que el proceso de trabajo, caracterizado porque el capitalista consume la fuerza de trabajo, es un proceso en el que el obrero trabaja bajo el control del capitalista, a quien pertenece la fuerza de trabajo del obrero, y el producto es propiedad del capitalista.

Una vez hecho el análisis del proceso de producción como proceso de trabajo, es decir, como consumo capitalista de la fuerza de trabajo, Marx pasa al análisis del proceso productivo como proceso de formación de valor. Y aquí se desplaza del valor de uso al valor de cambio. La formación de valor ocurre mediante el intercambio mercantil, pues el:

vendedor de la fuerza de trabajo, al igual que el vendedor de otra mercancía, realiza su valor de cambio y enajena su valor de uso. No puede conservar el uno sin ceder el otro (...) El poseedor de dinero ha pagado el valor de una jornada de fuerza de trabajo: le pertenece, por consiguiente, su uso durante la jornada, el trabajo de una jornada. La circuns- 
tancia del mantenimiento diario de la jornada de trabajo sólo cueste media jornada laboral, pese a que la fuerza de trabajo pueda operar o trabajar durante un día entero, y el hecho, por ende, de que el valor creado por el uso de aquélla durante un día sea dos veces mayor que el valor diario de la misma, constituye una suerte extraordinaria para el comprador, pero en absoluto una injusticia en perjuicio del vendedor [Marx, 1982 t. I, vol. I: 235)].

De este modo, gracias al consumo de la fuerza de trabajo en el proceso productivo, se ha formado un nuevo valor, mayor que el que el comprador de la fuerza de trabajo ha pagado al vendedor: "el artilugio, finalmente ha dado resultado. El dinero se ha transformado en capital” [Marx, 1982, t. I, vol. I: 235]. De este modo, "al transformar el dinero en mercancías que sirven como materias formadoras de un nuevo producto o como factores del proceso laboral, al incorporar fuerza vida de trabajo a la objetividad muerta de los mismos, el capitalista transforma valor, trabajo pretérito, objetivado, muerto, en capital, en valor que se valoriza a sí mismo". Finalmente, Marx establece la diferencia entre el proceso de formación de valor y el proceso de valorización, sosteniendo que "este último no es otra cosa que el primero prolongado más allá de cierto punto. Si el proceso de formación de valor alcanza únicamente al punto en que con un nuevo equivalente se reemplaza el valor de la fuerza de trabajo pagado por el capital, estaremos ante un proceso simple de formación del valor. Si este proceso se prolonga más allá de este punto, se convierte en proceso de valorización” [Marx, 1982, t. I, vol. I: 236].

Es gracias a este extraordinario análisis que Marx pudo explicar, de manera categórica, el mecanismo de la explotación capitalista, la misma que no era percibida si sólo se reparaba en el intercambio mercantil de trabajo por dinero en la esfera de la circulación, es decir, en el intercambio 
de equivalentes. Para esto, Marx había cuestionado la concepción dominante de economía política establecida por Smith, quien sostenía que se orientaba a explicar las causas de la riqueza de una nación, y de manera específica, las formas en que se debía producir la riqueza para el soberano y el pueblo, legitimando la dominación y explotación capitalista. Por el contrario, Marx rechazó esta visión e hizo una crítica que contribuyó a desnaturalizar la opresión capitalista y a mostrar que la visión de Smith de una vida mejor para todos, una vida de abundancia material y de riqueza, no era sino una quimera que quedó desmentida por la extensión del capitalismo salvaje en Europa en la primera mitad del siglo XIX.

Marx se basó en la concepción de trabajo productivo e improductivo de Smith, aunque sometiéndola a la crítica, sosteniendo que el trabajo productivo, en su significado para la producción capitalista, es trabajo asalariado que, cambiado por la parte variable del capital (la destinada a salarios), reproduce no sólo dicha porción, sino que además produce plusvalía para el capitalista. Por tanto: "sólo es productivo el trabajo asalariado que produce capital. Esto equivale a decir que reproduce en escala ampliada, la suma de valores que se invirtieron en él, o que devuelve más trabajo del que recibe en forma de salarios. Por consiguiente, sólo es productiva la fuerza de trabajo que crea un valor mayor que el suyo propio" [Marx, 1969: 129-130].

\section{LA ALIENACIÓN DEL TRABAJO EN EL CAPITALISMO}

Hemos considerado el acto de la enajenación de la actividad humana práctica, del trabajo, en cuatro aspectos: 1) la relación del trabajador con el producto del trabajo como con un objeto ajeno y que lo domina. Esta relación es, al mismo tiempo, la relación con el mundo exterior sensible, con los objetos naturales, como con un mundo extraño para él y que se le enfrenta con hostilidad, 2) la 
relación del trabajo con el acto de la producción dentro del trabajo. Esta relación es la del trabajador con su propia actividad, como con una actividad extraña, que no le pertenece, la acción como pasión, la fuerza como impotencia, la generación como castración, la propia energía física y espiritual del trabajador, su vida personal (pues qué es la vida sino actividad) como una actividad que no le pertenece, independiente de él, dirigida contra él. La enajenación respecto de sí mismo como, en el primer caso, la enajenación respecto de la cosa, 3) hace del ser genérico del hombre, tanto de la naturaleza como de sus facultades espirituales genéricas, un ser ajeno para él, un medio de existencia individual. Hace extraños al hombre ${ }^{30}$ su cuerpo, la naturaleza fuera de él, su esencia espiritual, su esencia humana, 4) una consecuencia inmediata del hecho de estar enajenado el hombre del producto de su trabajo, de su actividad vital, de su ser genérico, es la enajenación del hombre respecto del hombre. Si el hombre se enfrenta consigo mismo, se enfrenta también al otro. Lo que es válido respecto de la relación del hombre con su trabajo, con el producto de su trabajo y consigo mismo, vale también para la relación del hombre con el otro y con el trabajo, y el producto del trabajo del otro [Marx, 1976].

Un aspecto central de Marx en la crítica al capitalismo se refiere a la tendencia de éste de dividir y fragmentar el trabajo, a degradarlo y convertirlo en un apéndice de la máquina. Así, diría: "cierta atrofia intelectual y física es inseparable, incluso, de la división del trabajo en la sociedad como un todo. Pero como el período manufacturero lleva mucho más adelante esa escisión social entre los ramos del trabajo, y por otra parte hace presa por primera vez — con la división del trabajo que le es peculiar- en las raíces vitales del individuo, suministra también por

30 El lugar de enunciación de Marx está impregnado del patriarcalismo, pues no hace referencia a la mujer. 
primera vez el material y el impulso necesarios para la patología industrial" [Marx, 1982, t. I, vol. II: 442]. Marx refuerza esta visión con una cita de Ure: "subdividir a un hombre es ejecutarlo, si merece la pena de muerte, o si no la merece asesinarlo (...) La subdivisión del trabajo es el asesinato de un pueblo" [Marx, 1982, t. I, vol. II: 442].

A esto se suma la degradación de las condiciones laborales y salariales, pues la división del trabajo y la mecanización, destruyen las calificaciones y la visión de conjunto que tenía el artesano sobre el proceso productivo, expulsa a trabajadores al desempleo, hecho que repercute negativamente en los salarios, condiciones laborales y niveles de bienestar al crearse el ejército industrial de reserva.

Se generaría, por tanto, la enajenación del trabajo, pues éste es separado de las demás actividades humanas, vaciado de contenido, efectuado por un pago monetario, según las condiciones dictadas por el patrón, el mismo que se apropia del producto del trabajo. Así, la enajenación del trabajo en la sociedad capitalista se "presenta, ante todo, como una separación radical entre el trabajo y todas las actividades humanas 'no económicas"' [Mandel, 1989: 240]. La gran mayoría de las personas no trabaja para desarrollar sus capacidades físicas, intelectuales y morales, sino "por necesidad, para poder satisfacer sus necesidades humanas al margen del trabajo". Al mismo tiempo, la enajenación se manifiesta "en la pérdida total de control del trabajador sobre sus condiciones de trabajo, sobre sus instrumentos de trabajo, sobre el producto de su trabajo (...) pérdida que se va acentuando precisamente a medida en que el aumento de la plusvalía relativa sustituye al aumento de la plusvalía absoluta, a medida que la jornada de trabajo se acorta a costa de una intensificación y una mecanización cada vez más inhumana de ese mismo trabajo" [Mandel, 1989: 240]. Elementos centrales de esta enajenación en el trabajo son el trabajo continuo, la cadena de montaje, la semiautomatización, la desaparición de las antiguas especializaciones 
y la generalización de los obreros especializados, de tal modo que el resultado es que el "trabajador ya no es más que un ínfimo eslabón de dos mecánicas monstruosas, la máquina propiamente dicha", es decir, los instrumentos de trabajo que lo aplastan, y la máquina social que con sus órdenes, su jerarquía, sus exigencias, sus sanciones y su inseguridad organizada lo aplasta también. A esto se suma el "tedio generado por el trabajo mecanizado que acaba por minar las fuerzas vitales del obrero" [Mandel, 1989: 241]. Finalmente, hay una enajenación de tipo global en la sociedad capitalista, y es la que se refiere a la mercantilización del trabajo y la vida, y a la competencia, pues "la lucha de todos contra todos implica la negación de los más fundamentales y más característicos móviles de acción de la humanidad: solidaridad, cooperación y ayuda mutua, amor al prójimo" [Mandel, 1989: 241]. Todas las cualidades, aspiraciones y posibilidades humanas sólo pueden lograrse al comprar bienes y servicios en el mercado. Así, la reducción del tiempo de trabajo no se asocia con un mayor tiempo de ocio humanizador, sino con ocios mercantilizados y deshumanizados.

La colonialidad de las otras formas de control del trabajo bajo la hegemonía del trabajo asalariado

Es importante señalar el reconocimiento social que va adquiriendo el trabajo asalariado en el capitalismo europeo entre los siglos XVI y xIx, esconde la devaluación del trabajo femenino blanco y no blanco, y la dominación y explotación de los no asalariados no europeos: "indios" y "negros", por medio de la esclavitud, la servidumbre y la refuncionalización de la reciprocidad en el caso de los "indios".

Quijano [2000] sostiene que en el capitalismo mundial había una combinación de formas de control del trabajo bajo la hegemonía del capital, de modo que se 
desarrolló una división racial y geográfica del trabajo, la que implicaba el trabajo asalariado para los blancos y el trabajo no asalariado para los no blancos. Quijano [2014: 204-205] afirma que, a partir del siglo XVI, con las nuevas identidades históricas producidas sobre la base de la idea de raza, fueron asociadas a la naturaleza de los roles y lugares en la nueva estructura global de control del trabajo. Así, ambos elementos (raza y división del trabajo) quedaron estructuralmente asociados y reforzándose mutuamente, a pesar de que ninguno de los dos era necesariamente dependiente del otro para existir o para cambiar. De ese modo se impuso una sistemática división racial del trabajo. En el área hispana, la Corona de Castilla decidió temprano el cese de la esclavitud de los indios para prevenir su total exterminio; entonces, fueron confinados a la servidumbre. A los que vivían en sus comunidades, les fue permitida la práctica de su antigua reciprocidad -el intercambio de fuerza de trabajo y de trabajo sin mercado- como una manera de reproducir su fuerza de trabajo en tanto siervos. En algunos casos, la nobleza india (una reducida minoría) fue eximida de la servidumbre y recibió un trato especial, debido a sus roles como intermediaria con la raza dominante, y le fue también permitido participar en algunos de los oficios en los cuales eran empleados los españoles que no pertenecían a la nobleza. En cambio, los negros fueron reducidos a la esclavitud. Los españoles y los portugueses, como raza dominante, podían recibir un salario, ser comerciantes, artesanos o agricultores independientes, en suma, productores independientes de mercancías. No obstante, sólo los nobles podían participar en los puestos altos y medios de la administración colonial, civil y militar [Quijano, 2000: 204-205].

La esclavitud, la servidumbre, la reciprocidad y la pequeña producción mercantil simple no se presentan en la historia mundial de manera lineal y evolucionista, no 
son anteriores al capitalismo, sino que están articulados estructuralmente a partir de la relación capital-trabajo. Discutir la colonialidad del trabajo, por tanto, requiere no sólo indagar cómo se estableció la legitimidad del trabajo asalariado, sino también dar cuenta de estas otras formas de control del trabajo, que bajo el lente homogeneizador eurocéntrico aparecen ocultas e inexistentes.

La esclavitud tuvo un papel decisivo en la expansión del capitalismo mundial; destaca, por un lado, la contribución de Williams [1975], quien llevó a cabo un estudio económico de la representación de la esclavitud y la trata del esclavo negro en el suministro del capital que financió la Revolución industrial en Inglaterra, y del capitalismo industrial maduro en la destrucción del sistema esclavista. Según este autor, la esclavitud era una institución económica de primera Importancia. Había sido la base de la economía griega y había edificado el Imperio romano. En los tiempos modernos, proporcionaba el azúcar para las tazas de té y café del mundo occidental. La esclavitud produjo el algodón que sirvió de base al capitalismo moderno. La esclavitud hizo al sur de Estados Unidos de América y a las islas del Caribe. En perspectiva histórica, forma parte de esa imagen general del maltrato a las clases menesterosas, de las frías leyes acerca de los pobres y las severas leyes feudales, y de la indiferencia con que la naciente clase capitalista "comenzaba a calcular la prosperidad en términos de libras esterlinas y se acostumbraba a la idea de sacrificar vidas humanas a la deidad de una mayor producción" [Williams, 1975: 4].

Por otro lado, se encuentra el aporte de Tomich [2011], quien sostiene que la esclavitud y su abolición no debe verse desde un enfoque evolutivo lineal, sino como relaciones complejas, múltiples y cualitativamente diferentes dentro de procesos globales de acumulación y división del trabajo. En esta perspectiva, plantea la existencia de dos relaciones cualitativamente distintas entre esclavitud y 
proceso de desarrollo esclavista, cada cual con diferentes papeles y significados en la economía mundial del siglo XIX. La primera estaba constituida por un conjunto específico de procesos sociohistóricos y desempeñó un papel particular en la formación de la economía mundial entre los siglos XVI y XIX. Esas relaciones fueron destruidas o radicalmente reconstituidas por la transformación de la economía mundial en el siglo XIX. La segunda fue creada por los procesos históricos y el conjunto de las relaciones sociales específicas de la propia economía mundial de la misma centuria. La segunda esclavitud, por tanto, consolidó una nueva división del trabajo y suministró un volumen considerable de materias primas y géneros alimentarios a las industrias centrales. Lejos de ser una institución moribunda durante el siglo XIX, la esclavitud demostró toda su adaptabilidad y vitalidad. En otras palabras, el autor afirma que la moderna esclavitud no fue siempre la misma entre los siglos XVI y XIX, pues al paso del siglo XVIII al siglo XIX un conjunto de sucesos históricos, entre los que destacan la Revolución industrial en Inglaterra y la hegemonía internacional de Gran Bretaña, condujeron a profundas reconfiguraciones en el mercado internacional. En un contexto de creciente desequilibrio en los precios de productos agrícolas e industrializados, un creciente consumo de determinados productos, como el café y el azúcar, demandados por el crecimiento de los obreros y sectores medios en centros urbanos ingleses y europeos, y la búsqueda de nuevas materias primas, como el algodón, las transformaciones mencionadas causaron la declinación de viejas áreas coloniales basadas en la esclavitud, pero al mismo tiempo afectaron otras áreas de manera contraria, pues en Cuba, el sur de Estados Unidos de América y Brasil, que eran zonas con escasa presencia de esclavitud, ésta se expandió en una escala masiva para atender la creciente demanda global de algodón, café y azúcar. En este sentido, la segunda esclavitud fue 
desarrollada no como una premisa histórica del capital productivo, sino como el presupuesto de su existencia y una condición para su reproducción [Tomich 2011: 96].

La servidumbre, como forma de control del trabajo en América Latina, se impuso a los "indios", quienes fueron despojados de sus tierras y su trabajo para servir en las encomiendas, las haciendas y las minas, principalmente. Como está documentado, los "indios", estaban organizados de manera comunal, en ayllus o calpullis, y trabajaban sus tierras a partir de la reciprocidad y llevando a cabo diversas labores para el Estado. Respecto al Tawantinsuyo, Murra [1978] registra la continuidad y el vigor de las instituciones y los valores andinos preincaicos: el arraigo a la agricultura, acceso a bienes gracias a los lazos de parentesco y reciprocidad; la continuidad y supervivencia efectiva en el estado inca de la agricultura, el pastoreo y la manufactura textil autosuficiente de la comunidad étnica campesina. El Estado estableció un conjunto de prestaciones rotativas (en el trabajo, el servicio militar y el tejido) y diseñó un conjunto de mecanismos redistributivos.

Con la Conquista y la Colonia se desestructuró la sociedad inca, despojando a los "indios" de sus tierras, destruyendo su organización social y persiguiendo sus creencias. Los "indios" fueron sometidos brutalmente a la esclavitud y la servidumbre, ocasionando en los primeros cincuenta años de la conquista una elevada mortandad. Bagú [1959: 195] sostiene que:

el régimen colonial hispano-portugués impuso a la mano de obra indígena y africana pésimas condiciones de trabajo y de vida. El trabajador blanco tuvo una suerte más cambiante, porque la posibilidad de mejorar el salario o ascender en la escala social se mantuvo para él siempre abierta. Para el indio o el negro, el destino fue trágico. Hablamos en los términos generales indispensables para caracterizar a todo un sistema, dentro del cual se producen excepciones que 
no alteran la verdad anunciada. La mano de obra colonial padeció un proceso incesante de desintegración, a consecuencias de las pésimas condiciones de trabajo y de vida a que estuvo sometida.

Esta situación afectó a las familias indígenas, tanto a mujeres como hombres, quienes despojados de sus tierras y obligados a pagar el tributo colonial, tuvieron que desarrollar diversos trabajos para pagar y lograr la reproducción familiar. En general, los hombres debían ir a las minas, y reproducían de manera refuncionalizada la mita, o mediante la prestación colectiva que se hacía en el Tawantinsuyo; las mujeres debían producir y vender artesanías y tejidos para, en muchas ocasiones, complementar lo necesario para pagar el tributo y para la subsistencia familiar.

Acerca de esta trágica situación, Bagú [1959: 196-197] reproduce un fragmento de la Real cédula del 27 de mayo de 1582, emitida por Felipe II a la Audiencia de Quito:

Nos somos informados que en esa provincia se van acabando los indios naturales de ella por los malos tratamientos que sus encomenderos les hacen y que habiéndose disminuido tanto los dichos indios, que en algunas partes faltan más de la tercia parte, les llevan las tasas por entero que es de tres partes, las dos más de lo que son obligados a pagar, y los tratan peor que esclavos y que como tales se hallan vendidos y comprados de unos encomenderos en otros, $\mathrm{y}$ hay algunos muertos a azotes y mujeres que mueren $\mathrm{y}$ revientan con las pesadas cargas, y a otras y a sus hijos les hacen servir en las granjerías y duermen en los campos y allí paren y crían mordidos de sabandijas ponzoñosas, y muchos se ahorcan y otros se dexan morir sin comer y otros toman hiervas venenosas y que hay madres que matan a sus hijos pariéndolos, diciendo que lo hacen para liberarlos de los trabajos que ellos padecen y que han concebido los dichos indios muy grande odio al nombre cristiano y tienen a 
los españoles por engañadores y no creen cosa de las que les enseñan, y así todo lo que hacen es por fuerza, y que estos daños son mayores a los indios que están en nuestra Real Corona, por estar en administración; y porque, como véis, de estos y otros malos tratamientos que a los dichos indios se hacen, viene el irse acabando tan a priesa y conviene remediarlo con gran cuidado.

La cédula, en la que se habla del sufrimiento de las mujeres indígenas por la explotación colonial, evidencia que la colonialidad del trabajo (entendida como la articulación de varias formas de control del trabajo bajo la hegemonía del trabajo asalariado) está articulada con la colonialidad del género, es decir, por otro ámbito crucial del poder, en la visión de Quijano ${ }^{31}$.

En este sentido, es valiosa la contribución hecha por De Assis [2016: 19], quien reflexiona en torno de la "modulación patriarcal del patrón mundial de poder”. Patriarcal, porque es "tendencialmente universal", puesto que en los pueblos en donde no habría una clara jerarquización de lo masculino sobre lo femenino o en donde no habría signos de su institucionalización, hay elementos patriarcales, materiales y simbólicos, sutilmente dispersos, que se desarrollan con facilidad frente a presiones patriarcales de pueblos externos [De Assis, 2016: 30]. También sostiene que el patriarcado está presente en los ámbitos simbólico, político y económico de la existencia social, manifiesta que respecto de lo económico, destaca la teorización colectiva del feminismo materialista francés (FMF), para el cual el factor determinante en la diferenciación entre hombres y mujeres es la apropiación material del cuerpo de las mujeres (y, por lo tanto, el irrestricto acaparamiento de su fuerza de trabajo y de su sexualidad, dentro de una lógica

31 Segato [2015] y Lugones [2008 y 2010] han problematizado y enriquecido el aporte de la colonialidad del sexo formulada por Quijano. 
próxima a la esclavitud [De Assis, 2016: 36]. El autor sostiene que sería posible hablar, en oposición al patriarcado del salario en los países centrales o en las clases medias periféricas, de un patriarcado dependiente, en el que el estatus masculino otorga a los hombres una superioridad sobre las mujeres, pero careciendo de una base material que la sustente. Esta ausencia de vínculo entre el estatus y la posibilidad de mantenerlo generaría una frecuente inestabilidad en la subjetividad masculina [De Assis, 2016: 56].

La perspectiva feminista inclinada hacia el marxismo ha hecho importantes contribuciones para entender la posición hegemónica del trabajo asalariado en el capitalismo mundial. Federici [2010: 23] propone repensar el desarrollo del capitalismo desde un punto de vista feminista, evitando las limitaciones de una historia de las mujeres separada del sector masculino de la clase trabajadora. La autora señala la necesidad de recurrir a Marx para entender la génesis del desarrollo capitalista, aunque señala un derrotero de análisis distinto, sosteniendo que:

mi análisis se aparta del de Marx por dos vías distintas. Si Marx examina la acumulación primitiva desde el punto de vista del proletariado asalariado de sexo masculino y el desarrollo de la producción de mercancías, yo la examino desde el punto de vista de los cambios que introduce en la posición social de las mujeres y en la producción de la fuerza de trabajo. De aquí que mi descripción de la acumulación primitiva incluya una serie de fenómenos que están ausentes en Marx y que, sin embargo, son extremadamente importantes para la acumulación capitalista. Éstos incluyen: i) el desarrollo de una nueva división sexual del trabajo que somete el trabajo femenino y la función reproductiva de las mujeres a la reproducción de la fuerza de trabajo; ii) la construcción de un nuevo orden patriarcal, basado en la exclusión de las mujeres del trabajo asalariado y su subordinación a los hombres; iii) la mecanización del cuerpo 
proletario y su transformación, en el caso de las mujeres, en una máquina de producción de nuevos trabajadores. Y lo que es más importante, he situado en el centro de este análisis de la acumulación primitiva las cacerías de brujas de los siglos XVI y XvII; sostengo aquí que la persecución de brujas, tanto en Europa como en el Nuevo Mundo, fue tan importante para el desarrollo del capitalismo como la colonización y como la expropiación del campesinado europeo de sus tierras (Federici, 2010: 23].

\section{Trabajo y disciplina}

Un punto relevante de reflexión está relacionado con la percepción del tiempo tanto en la colonialidad-modernidad como en los movimientos sociales que van cuestionando esta forma de vida. Se trata de plantear cómo, a medida de que se transformaba el concepto de trabajo orientado a lo homogéneo, abstracto, productivo y asalariado, simultáneamente operaba una percepción del tiempo que se alejaba de los ritmos de la naturaleza (estaciones, día y noche) y que lo disociaba de la vida cotidiana para convertirlo en tiempo medido, en tiempo-mercancía, en tiempo valorizado en dinero. Es en este contexto que el reloj como instrumento de medición del tiempo cobra importancia y difusión creciente, para permitir no sólo el disciplinamiento de la fuerza de trabajo dentro de las fábricas, sino también facilitar la instalación de una nueva ética social - la puritana- que proponía una valoración extrema del trabajo y condenaba el ocio y el dispendio, como Thompson [1984], Le Goff [1969 y 1983], Attali [1985] y Febvre [1992], entre otros lo han demostrado.

Al mismo tiempo, la imposición de una nueva manera de entender el trabajo, en tanto empleo, va acompañada de una nueva concepción del tiempo y de la disciplina. Respecto del tiempo, Thompson plantea que la idea de trabajo en el capitalismo, como algo instrumental, separado 
de la vida y del tiempo natural y basado en la eficiencia económica medios-fines, se fue imponiendo mediante el tiempo medido y de la disciplina. El tiempo medido por el reloj, que definió el trabajo.

Al respecto, Foucault [2003: 156-157] sostiene que en el capitalismo se han desarrollado métodos que pueden llamarse disciplinas, en tanto métodos generales de dominación, ya que permiten el control minucioso de las operaciones del cuerpo, garantizan la sujeción constante de sus fuerzas y les imponen una relación de docilidad-utilidad. Foucault [2003: 156-157] afirma que estos métodos disciplinarios se diferencian de la esclavitud, la domesticidad, el vasallaje y el ascetismo, pues:

El momento histórico de las disciplinas es el momento en que nace un arte del cuerpo humano, que no tiende únicamente al aumento de sus habilidades, ni tampoco a hacer más pesada su sujeción, sino a la formación de un vínculo que, en el mismo mecanismo, lo hace tanto más obediente cuanto más útil, y al revés. Fórmase entonces una política de las coerciones que constituyen un trabajo sobre el cuerpo, una manipulación calculada de sus elementos, de sus gestos, de sus comportamientos. El cuerpo humano entra en un mecanismo de poder que lo explora, lo desarticula y lo recompone. Una "anatomía política", que es igualmente una "mecánica del poder", está naciendo; define cómo se puede hacer presa en el cuerpo de los demás, no simplemente para que ellos hagan lo que se desea, sino para que operen como se quiere, con las técnicas, según la rapidez y la eficacia que se determina.

La disciplina [Foucault, 2003: 142] fabrica así cuerpos sometidos y ejercitados, cuerpos dóciles. La disciplina aumenta las fuerzas del cuerpo (en términos económicos de utilidad) y disminuye esas mismas fuerzas (en términos po- 
líticos de obediencia). Estas disciplinas se aplican en las escuelas, en los hospitales, en los cuarteles y en las fábricas.

Galcerán [2016: 237-238] sostiene que si bien el aporte de Foucault respecto de las disciplinas de dominación, de control minucioso del uso del tiempo y del espacio desarrolladas por el humanismo ilustrado a partir del cuerpo es muy importante, deja de lado la colonialidad del poder, pues:

Foucault entiende que la diferencia entre un "suplicio corporal" y un "empleo del tiempo" es lo que separa el arte de castigar entre 1757 y principios del XIX, cuando en menos de un siglo desaparecen los suplicios. Pero entre ellos no introduce los que reinan en los territorios coloniales. Si miramos desde ellos, esta afirmación resulta excesiva. La esclavitud no se elimina hasta mediados del xIx y el suplicio y los castigos físicos eran práctica habitual en el trato de los esclavos, lo mismo que el marcaje de su cuerpo con las iniciales del amo. El "humanismo" no se aplica en las colonias, sólo en las metrópolis y condicionadamente"32.

\section{Las tensiones eurocéntricas en el pensamiento de Marx}

\section{LAS DUALIDADES DIALÉCTICAS DEL ANÁLISIS DE MARX}

Según Lander todo el análisis de la producción capitalista llevado a cabo por Marx está atravesado por una dualidad fundamental entre un aspecto de carácter claramente histórico - producto específico de la sociedad capitalista y sus condiciones de dominación y explotación- y un aspecto "natural", históricamente progresista, que puede

32 En este sentido, Foucault no incorpora en su análisis el hecho colonial y la colonialidad. Un balance crítico de los aportes de Foucault desde la colonialidad puede verse en Galcerán [2016]. 
ser separado de las condiciones históricas concretas que le dieron origen. Y esta dualidad está presente en el análisis de la categoría básica del análisis marxista, la mercancía, la cual tiene valor de uso y valor de cambio:

Las categorías fundamentales del análisis de la producción capitalista pueden ser vistas así como dos conjuntos de categorías que, tomadas de dos en dos, se refieren a los mismos problemas, están construidas a partir de los mismos referentes empíricos, pero una desde una perspectiva histórica (referida a la sociedad capitalista), y otra desde una perspectiva que tiene que ver con aquello que es considerado como constitutivo del hombre como especie. La categoría básica del análisis de la producción capitalista, la mercancía, está definida por Marx a partir de su carácter bifacético, como portadora simultáneamente de valor de uso y de valor de cambio [Lander, 2008: 182].

Dicha mercancía lo es porque al mismo tiempo es valor de uso y valor de cambio, tiene la propiedad de satisfacer una necesidad y al mismo tiempo es portadora de valor. El valor de uso hace referencia al hombre genérico, como ser que tiene necesidades y requiere de la producción para su satisfacción. Por el contrario, el valor de cambio se refiere a las condiciones específicas de la producción en el régimen capitalista, condiciones en las cuales sólo se produce aquello que es capaz de contribuir al proceso de valorización del capital. Para Marx es tan central este carácter bifacético de la mercancía que lo considera “(...) el eje en torno al cual gira la comprensión de la economía política" [Lander, 2008: 182].

$\mathrm{Al}$ analizar la dualidad del trabajo representado en la mercancía en el capítulo I de El Capital, Marx sostenía que:

En un comienzo, la mercancía se nos puso de manifiesto como algo bifacético, como valor de uso y valor de cambio. 
Vimos a continuación que el trabajo, al estar expresado en el valor, no poseía ya los mismos rasgos característicos que lo distinguían como generador de valores de uso. He sido el primero en exponer críticamente esta naturaleza bifacética del trabajo contenido en la mercancía [Marx, 1982, t. I, vol. I: 51].

Esta dualidad dialéctica que parte de la naturaleza bifacética de la mercancía, está presente en la construcción de todas las categorías básicas de interpretación del régimen de producción capitalista y limita la capacidad crítica del marxismo en relación con este régimen de producción. Si bien Marx logra desnaturalizar las relaciones sociales de dominación y explotación señalando que son históricas, es decir, transitorias y no son naturales ni eternas, al mismo tiempo hay un límite en esa crítica al asumir que ciertas categorías no son históricas y propias del capitalismo, sino naturales, características de la historia humana en su conjunto. En palabras de Lander [2008: 189-190]:

Pero, así como la desnaturalización de aquello que para el pensamiento burgués aparece como natural, es una medida de la profundidad y radicalidad del cuestionamiento de Marx al régimen de producción capitalista, los límites de esa desnaturalización de las "categorías naturales" de la economía política señala igualmente los límites de esa crítica (...) El conjunto de categorías que hemos señalado como históricas señalan lo que es la profundidad y radicalidad de la crítica marxista a la sociedad capitalista. La división social del trabajo, el valor de cambio, el trabajo abstracto, las relaciones de producción, son caracterizados como productos particulares del capitalismo, y por lo tanto, como históricos y transitorios: en estos términos son desnaturalizados. Se les quita la aureola de inevitabilidad y eternidad con la cual quedan cubiertos estos fenómenos en la teoría económica clásica sentándose así el piso teórico para 
su negación. Sin embargo, cuando Marx habla de fuerzas productivas, de trabajo concreto, de valor de uso, de división técnica del trabajo, está formulando categorías teóricas que tienen otro significado. Estas categorías no son concebidas como instrumentos teóricos para la crítica de la sociedad capitalista, sino como caracterizaciones científicas de aspectos "naturales", que expresan el desarrollo histórico del hombre como especie. De esta manera se termina por asumir como eterno, necesario y natural lo que en los propios términos de la teoría marxista no es sino una expresión histórica concreta y por lo tanto transitoria, de la sociedad capitalista. $\mathrm{Al}$ asumir que estos aspectos de la sociedad burguesa están sustentados sobre la naturaleza del hombre, o sobre las leyes necesarias del desarrollo histórico, el marxismo no es capaz de tomar distancia en relación a estos aspectos de la sociedad capitalista. El desarrollo siempre en expansión de las fuerzas productivas, las necesidades, el trabajo útil, el trabajo concreto, la división técnica del trabajo, la relación del hombre con la naturaleza fundada en la permanente transformación útil de ésta, son concebidos por Marx como hechos naturales, inevitables que tienen que ver con la esencia del hombre como tal y por lo tanto, pueden no solo ser separadas, sino también liberadas de las restricciones que les imponen las condiciones políticas y económicas dentro de las cuales se presentan estas dimensiones naturales del hombre dentro de la sociedad capitalista.

\section{Trabajo y fuerzas productivas, alienación}

y neutralidad de la tecnología

Las dificultades implicadas en la utilización de las dualidades dialécticas para la desnaturalización de las categorías básicas de la economía política pueden ser evidenciadas en la relación trabajo y fuerzas productivas. Por un lado, Marx crítica de modo sistemático al capitalismo por la cosificación del trabajo, en lo que él mismo denominó una patología industrial. Por otro, a pesar de 
sostener que la introducción de maquinaria y la aplicación de los conocimientos científicos a la producción son un mecanismo para someter, desvalorizar y descalificar a la fuerza de trabajo, Marx plantea que la tecnología es un artefacto neutral respecto de las relaciones de poder y que puede ser utilizada en otro tipo de organización social, de modo que pueden suprimirse los efectos negativos de las fuerzas productivas utilizadas en el sistema capitalista [Lander, 2008: 169-181]. Esto significa para Marx, en síntesis, que:

el problema no reside en la máquina sino en la aplicación o utilización que esta tiene en la sociedad burguesa (...) es un hecho indudable que la maquinaria no es responsable en sí de que a los obreros se los "libere" de los medios de subsistencia. Las contradicciones y antagonismos inseparables del empleo capitalista de la maquinaria no existen, ya que no provienen de la maquinaria misma, sino de su utilización capitalista! Por tanto, como considerarla si en sí misma la maquinaria abrevia el tiempo de trabajo, mientras que utilizada por los capitalistas lo prolonga; como en sí facilita el trabajo, pero empleada por los capitalistas aumenta su intensidad; como en sí es una victoria del hombre sobre las fuerzas de la naturaleza, pero empleada por los capitalistas impone al hombre el yugo de las fuerzas naturales; como en sí aumenta la riqueza del productor, pero cuando la emplean los capitalistas lo pauperiza, etc., el economista burgués declara simplemente que el examen en sí de la maquinaria demuestra, de manera concluyente, que todas esas contradicciones ostensibles son mera apariencia de la realidad ordinaria, pero que en sí, y por tanto también en la teoría, no existen. Con ello, se ahorra todo quebradero adicional de cabeza y, por añadidura, achaca a su adversario la tontería de no combatir el empleo capitalista de la maquinaria, sino la maquinaria misma [Marx, citado por Lander, 2008: 181]. 
En este sentido, el análisis de Marx respecto de las fuerzas productivas desarrolladas por el capitalismo presenta una profunda ambivalencia. Por un lado, asombro por las grandes capacidades productivas logradas por la ciencia y la tecnología, y por el desarrollo industrial de la sociedad burguesa. De este modo, las fuerzas productivas son consideradas progresistas, como creadoras de la base material imprescindible para construir la sociedad comunista. Por otro lado, se crítica la alienación del trabajador: desvalorización, descalificación, sujeción al patrón, pérdida del control de sus medios y productos del trabajo, desempleo, pauperización, conversión en apéndice de la máquina. Lo que adquiere mayor relieve en el análisis de Marx acerca de la alienación en el trabajo y las fuerzas productivas es que generan la patología industrial, por su uso capitalista y no en sí mismas, como si fueran neutras. Por tanto, tales fuerzas productivas, utilizadas para construir una sociedad socialista serán la base de la abundancia material y de un tipo de trabajo que se humanizará crecientemente [Lander, 2008].

\section{El evolucionismo}

Si bien Marx develó el mecanismo de la explotación capitalista, al mismo tiempo contribuyó a la consolidación de un concepto de trabajo extremadamente economicista y excluyente de otras formas históricoculturales de trabajo en torno a las que gira la satisfacción de las necesidades básicas y la reproducción social.

El concepto de trabajo de Marx, creado a partir de las ideas de valor de uso y valor de cambio, trabajo productivo y trabajo no productivo, es un concepto ceñido a lo económico y productivo, y a la relación laboral asalariada. Marx define el trabajo productivo de la siguiente manera:

el trabajo productivo, en su significado para la producción capitalista es trabajo asalariado que, cambiado por la parte 
variable del capital (la parte del capital que se destina a salarios), reproduce no sólo dicha porción del capital (o el valor de su propia fuerza de trabajo), sino que además produce plusvalía para el capitalista. Sólo de esta manera la mercancía o el dinero se convierten en capital, se producen como capital. Sólo es productivo el trabajo asalariado que produce capital. (Esto equivale a decir que reproduce, en escala ampliada, la suma de valores que se invirtieron en él, o que devuelve más trabajo del que recibe en forma de salarios. Por consiguiente, sólo es productiva la fuerza de trabajo que crea un valor mayor que el suyo propio. La simple existencia de una clase de capitalistas, y por lo tanto del capital, depende de la productividad del trabajo, pero no de su productividad absoluta, sino de la relativa [Marx, 1985: 129$]^{33}$.

La cita anterior tiene como finalidad reforzar la idea del peso que Marx le daba al trabajo asalariado como trabajo productivo. Al respecto se puede ver, Dussel [1988: 137-141], quien señala que Marx planteaba tres acepciones del trabajo productivo: "Uno amplio, en su significación "absoluta" (cuando alcanza "solamente a sostener la vida del obrero, es decir, a reproducir la capacidad de trabajo"; 440, 4-5; I, 137). En otro sentido, abstracto y material, el "trabajo verdaderamente (wahrhaft) productivo" (440, 22; I, 138), que es el que produce valor de uso para el obrero mismo en el caso de que no existiera capital (el plustrabajo sería para el trabajador), el cual establece una relación con "el auténtico (eingentliche) producto" (518,

33 Esto no significa ignorar que Marx contempló otras formas de trabajo productivo que no estaban relacionadas con la producción material, como la actividad comercial o inmaterial (Marini, 1993; De la Garza, 2010: 2). Lo que quiere destacarse es el hecho que Marx no reconoció la heterogeneidad histórico-estructural del trabajo, esto es, la existencia legítima de otras formas de control del trabajo no asalariadas y no capitalistas como generadoras de riqueza, que estaban subordinadas a la relación capital-trabajo. 
17; I, 180). En este segundo significado, el trabajo podría ser productivo en una sociedad poscapitalista. Pero en este parágrafo el sentido de la denominación trabajo productivo, establece una relación con la productividad relativa: la base de esta productividad es la productividad relativa, en la que el trabajador, además de reponer el valor anterior, crea un valor nuevo, en que objetiva en su producto más tiempo de trabajo del objetivado en el producto que sostiene su vida como trabajador (440, 14$18 ;$ I, 137). En este tipo de trabajo productivo, se cifra el origen del plusvalor, "la esencia (Wesen) del capital" (440, 25; I, 138). El tercer tipo de trabajo productivo según Dussel es: "el hecho de producir mercancías, no sólo por crear plusvalor, aunque en realidad es lo mismo con diferente referencia:

A medida que el capital va adueñándose de toda la producción (...) va estableciéndose también, más y más una diferencia material entre trabajadores productivos e improductivos, en el sentido de que los primeros, con raras excepciones, producen exclusivamente mercancías, mientras los segundos, salvo excepciones muy contadas, ejecutan solamente prestaciones de servicios personales. Por tanto, la primera clase produce la riqueza directa, material, formada por mercancías $(447,25-33$; I, 145).

El capital se emplea en subsumir trabajo para producir mercancías: es entonces trabajo productivo. El ingreso (ganancia, renta o aun salario) puede cambiarse por trabajo, pero en ese caso el trabajo produce prestaciones personales: bienes para el uso personal (trabajo improductivo). Así, como plantea Ibáñez [2002: 158-159], se trata de un concepto:

que (...) se ha convertido en paradigma de todo trabajo pues es una "actividad libre, voluntariamente prestada, lo que 
excluye trabajos forzosos o la esclavitud" (...) al mismo tiempo es una "actividad retribuida: el trabajo es la forma de conseguir la subsistencia propia y de la familia, así como la identidad social del trabajador", es también una "actividad dependiente: la energía personal del trabajador queda dirigida (organizada, controlada, sancionada) por otro", y el "trabajo productivo es por cuenta ajena: el trabajador necesita ponerse al servicio de otra persona que posee los medios de producción, lo que significa que el trabajador se desentiende, al menos en principio, de los riesgos inherentes al proceso productivo.

El trabajo en sentido abstracto y homogéneo es una creación de Smith, pues lo que le interesaba era establecer que el trabajo era productor de valor, sin importar, como sostiene Naredo [1987] el trabajo como productor de materia, pues el valor es una categoría eminentemente social, ya que sólo se concibe como fruto de relaciones entre individuos. Para esto era necesario referir la cantidad de trabajo incorporado en cualquier mercancía en términos del tiempo, ya que en la base del intercambio está la cantidad de trabajo (tiempo) socialmente incorporado en cada mercancía. Según Naredo [1987] esta concepción del trabajo es la base de la lógica del valor y la productividad. El afán medidor y cuantificador de la realidad del siglo XVIII encuentra su acomodo también en la economía, pudiendo medir el esfuerzo y cambiarlo por valor a partir de la medida del tiempo. La riqueza de las naciones será el resultado de la suma de la cantidad de trabajo y la proporción entre los que desempeñan un trabajo productivo y el resto de la población. Éste es el germen de una división social entre la población que trabaja, y por tanto, produce riqueza, y aquella que es improductiva. Por consiguiente, la economía establece un concepto de trabajo elaborado teóricamente, instrumental y abstracto [Meda, 1998: 52]. 
El trabajo (productivo) y clasificación social en Marx

Desde que Marx toma para sí, de modo crítico $^{34}$, el concepto de trabajo productivo desarrollado por Smith y lo convierte en una de las principales categorías de la crítica a la economía política liberal, surgen diversas implicaciones decisivas en relación con la legitimidad de cierto tipo de trabajo y su importancia en la vida social, así como respecto de la clasificación social. Esto se explica porque la importancia atribuida al trabajo asalariado no procede sólo del pensamiento y prácticas dominantes, sino de su principal crítico.

Por un lado, el concepto de trabajo productivo en tanto única forma civilizada de crear valor y riqueza, contribuyó a instalar en los imaginarios sociales una visión economicista, secularizada, homogenizante, evolucionista y universalista del trabajo, identificado como trabajo asalariado. Esta visión fortaleció los procesos de alienación del trabajo, pues según Ibáñez [2002: 162-163]:

reforzó la imagen (y la realidad) del capital como organizador y controlador del trabajo en todos sus aspectos (sobre la inversión, la utilización de maquinaría, el rendimiento del trabajador, los niveles salariales y las condiciones de trabajo, la calidad de la producción). Este proceso de alienación se profundizó cuando a la visión economicista secularizada del trabajo se le añadió la categoría de productividad como criterio supremo para la valoración social del trabajo en general, y de cada trabajador en particular.

Tal enfoque, al restringirse a lo económico y a la eficiencia instrumental, separa, en términos eurocéntricos,

34 Es evidente que Marx [1985] toma el concepto de trabajo productivo de Smith de modo crítico, estableciendo que tenía confusiones entre valor y plusvalor, por un lado, y entre plusvalor y ganancia. Al respecto, ver Dussel [1988], especialmente el apartado 7, "Las perplejidades de Adam Smith". 
el trabajo en tanto una actividad que contribuye a la realización personal y una actividad de vínculo social. Esto es, separa el trabajo de la vida.

Respecto de la clasificación social, es decir, la distribución de las personas en las relaciones de poder en una sociedad, Marx le asignaba un lugar central en las relaciones de mando-obediencia al control de los medios de producción y al trabajador asalariado como el sujeto básico de la dominación y explotación en la sociedad capitalista, y al mismo tiempo, de la emancipación definitiva. Esta concepción era problemática porque no reconocía otros elementos también decisivos (raza y sexo) respecto de la clasificación social, y porque su concepción restrictiva del trabajo asalariado en tanto trabajo productivo no legitimaba en el ámbito de construcción de ciudadanía del Estado-nación, el acceso a tener derechos laborales a quienes no estuvieran sujetos a la relación capital-trabajo.

Al hacer la crítica al trabajo productivo de Smith (ver apartado anterior), se sostuvo que tal concepto excluía otras formas de control del trabajo, porque no se consideraba la heterogeneidad histórico-estructural, sino una perspectiva evolucionista y homogenizante, según la cual, el avance del capitalismo conduciría a la depuración de todas las formas de trabajo precapitalistas y arcaicas, en el mundo entero; esto es, a la proletarización total de la fuerza de trabajo mundial.

Analizando el capitalismo histórico, el capitalismo de "carne y hueso", Wallerstein [1988: 17] discute la expectativa de que ocurriera una proletarización masiva de la fuerza de trabajo, y que el proletariado creciera de manera mayoritaria entre los trabajadores; sostenía que esta proletarización en la economía-mundo capitalista ha sido parcial y llegaba a alrededor de cincuenta por ciento de la fuerza laboral mundial a fines de los años ochenta del siglo pasado. La explicación de esta anomalía tiene que ver con que, en su búsqueda de reducir costos laborales, 
los capitalistas recurren a trabajadores que viven en las economías domésticas proletarizadas sólo de manera parcial; como no se reproducen exclusivamente a partir de relaciones asalariadas, sino también de llevar a cabo otras actividades (agricultura para el autoconsumo o venta, artesanías), podían aceptar salarios más bajos que los integrantes de las primeras. Así, Wallerstein [1988: 17] concluye que:

De esta forma, el trabajo no asalariado permitió a algunos productores pagar un salario inferior a sus trabajadores, reduciendo así sus costos de producción e incrementando sus márgenes de ganancia. No es de extrañar, pues, que, por regla general, todos los que empleaban mano de obra asalariada prefirieran que sus asalariados vivieran en unidades domésticas semiproletarias en lugar de proletarias.

El punto ciego respecto de los otros tipos de trabajo (los considerados no productivos) también está presente dentro de esta visión homogenizante respecto de las clases sociales, pues se resaltan dos imágenes poderosas: la de la clase burguesa (burguesía) y de la clase proletaria (proletariado), como si ambas, en su interior, fueran homogéneas. Esta visión distorsionaba la realidad, porque ambas clases eran diferenciadas en su interior, entre y dentro de los países europeos, para no hablar de lo que ocurría fuera de Europa. Palmade [1976: 157], al analizar las clases sociales en la Europa capitalista (Inglaterra, Francia y Alemania de la segunda mitad del siglo XIX), sostiene que uno de sus rasgos básicos es su heterogeneidad, por lo que hablar de clase y no de clases burguesas y de clases obreras era cuestionable. El concepto restrictivo y eurocéntrico de clase obrera, en tanto clase asalariada productora de riqueza sigue siendo ciego, porque tan sólo en Inglaterra la situación era muy diferente. Palmade [1976: 157], señala que, si se definía al trabajador obrero con criterios solamente 
económicos, el término proletariado sólo correspondía a uno de cada dos individuos; existían otros trabajadores asalariados (entre ellos, según la definición de Sombart, empleados domésticos, asalariados agrícolas, empleados de comercio o de los servicios de transporte, agentes subalternos de los servicios, repartidores), pero que no correspondían al perfil del proletariado moderno: asalariado, libertad de trabajo y movilidad, concentración en grandes centros industriales, trabajo disciplinado a máquina, pago por pieza. Pero este proletariado moderno se diferenciaba tanto en su composición como por sus condiciones de trabajo. Había obreros especializados, fabricantes de máquinas y encargados del mantenimiento que ganaban de cinco a seis chelines por día. Luego seguían, en una escala social descendente, los obreros de fábrica que tenían jornadas de hasta dieciséis horas diarias. En la industria algodonera, las mujeres y los niños ocupaban la mitad y la cuarta parte de los puestos de trabajo, respectivamente; el trabajo era precario y el jornal oscilaba entre los dos y cuatro chelines. Los trabajadores a domicilio ganaban un chelín. En el último peldaño, una gran cantidad de inadaptados estaban internados en las workhouses. A esta masa laboral se sumaba el gran contingente de migrantes irlandeses (un "ejército industrial de reserva") quienes se dedicaban a cumplir con los trabajos más duros y peor pagados.

Acerca de la heterogeneidad de la fuerza de las clases trabajadoras, Wolf [2014: 433-434] plantea que difiere en su origen, en el punto de entrada a la fuerza de trabajo, en su composición, y en la forma en que se relaciona con otros grupos y categorías sociales. Afirma, por ejemplo, que respecto a la composición en la primera fase de la industrialización, la fuerza de trabajo en Inglaterra, reclutada en las hilanderías, estaba conformada por mujeres, niños y aprendices pobres, mientras que en Bombay, eran mayormente varones adultos casados, y en Nueva 
Inglaterra consistía en mujeres jóvenes y adultas. También las clases trabajadoras diferían en la ubicación, alcance geográfico y capacidad de apoyo de los lazos sociales fundamentales para su mantenimiento y reproducción. En las poblaciones textiles inglesas de 1850, las unidades constitutivas de la clase trabajadora fueron familias iniciales o derivadas, que enfrentaban los problemas de la supervivencia enviando a trabajar a las mujeres y los niños, o bien anexándose a grupos domésticos mayores. Muchas familias se apiñaban en viviendas compartidas. Al mismo tiempo, quienes estaban en las poblaciones dedicadas a la textilería procuraban mantener vínculos con parientes que residían en el campo, con la finalidad de maximizar las ventajas mutuas. Mientras tanto, los obreros textiles de India dejaban a sus mujeres e hijos con sus familias comunes en sus poblados de origen, y luego regresaban para que otros miembros de la familia ocuparan sus lugares en el trabajo. Wolf sostiene que las características de una clase trabajadora están determinadas no solamente por el vínculo del salario, sino también por lazos de parentesco, localidad y asociación que salvan las distancias entre poblaciones de origen y las nuevas vecindades de las regiones industriales.

En Marx, la raza no tiene una presencia decisiva como elemento de clasificación social. Según Bagú [1972: 110111] cuando Marx y Engels iniciaron sus reflexiones, había una preocupación en la tradición cultural occidental respecto de la existencia de las clases sociales y de desentrañar su naturaleza, siendo los conceptos centrales clase, casta, estamentos, élites gobernantes y grupos profesionales. Otros tipos de agrupamientos (familia, élites profesionales y aristocracias, grupos generaciones, estatus de la mujer), no tuvieron igual tratamiento. En esta misma orientación de la cultura occidental, el tema étnico tenía una presencia "hipertrófica", pues con la constitución de la economía mundo capitalista desde la segunda mitad del siglo XVI: 
se transformó en habitual lo que hasta entonces había sido exotismo: el contacto directo con seres humanos de distinto aspecto físico, distintas lenguas y religiones; y distintos tipos organizativos. Europa occidental se transformó en metrópoli de un inmenso mundo colonial. Sus teóricos, por muy poco imaginativos que fueran, no podían menos que observar que, en las nuevas funciones de mando y obediencia que se generalizaron en el mundo internacional, a los de tez más clara les correspondía el mando y a los de tez más oscura la obediencia Bagú [1972: 110-111].

Durante el siglo XIX se expandió una actividad profesional que buscaba medir y clasificar a partir de ciertos parámetros a los seres humanos, para demostrar la superioridad de los europeos y clasificar a las sociedades según sus etapas evolutivas, y así justificar la preeminencia de las sociedades europeas sobre las otras. "Buena parte de la energía creadora de los científicos europeos durante el siglo XIX se malgastó en esta colosal superchería, que sólo después de 1945 pasó a ser generalmente reconocida como ausente de todo fundamento científico respetable" [Bagú. 1972: 112]. Este mismo autor dice que en la obra de Marx y Engels hay un conjunto de temas, vinculados entre sí que aparecen de modo marginal, "tanto por la ínfima importancia que tienen dentro del planteamiento teórico general como porque las más de las veces los mencionan sólo al pasar". Estos temas eran el étnico y el judaísmo, muy presentes en los estudios históricos y antropológicos, y en el discurso político de los dirigentes europeos de la época. Tanto en Marx como Engels había una visión en la que existían pueblos civilizados y otros semicivilizados y bárbaros, con la coincidencia de que los primeros son los del centro y oeste de Europa, y a veces, también de Estados Unidos de América; esto ya aparece en los Principios del comunismo, que Engels redacta en 1847. Sostenía que el desarrollo de la gran industria había dado nacimiento 
a las "dos clases decisivas de la sociedad" en "todos los países civilizados", por lo que la "revolución comunista" tendría que desarrollarse en ellos (Inglaterra, Estados Unidos de América, Francia y Alemania). Alemania en esa época no tenía una gran industria y carecía de unificación política y EUA presentaba un desarrollo industrial en el noreste combinado con el esclavismo en el sur, el mayor en el mundo. No importaba para Engels la incipiencia del desarrollo de la industria en Alemania o la práctica extendida de la esclavitud en el sur de EUA: "Alemania y Norteamérica son civilizados: el resto de la humanidad, a contrario sensu, no lo es” [Bagú, 1972: 142-143]. ¿Por qué esta clasificación arbitraria de lo civilizado? Bagú sostiene que "este modo de clasificar culturas aparece en Engels, como en Marx, aquí y allá, en redacciones muy descuidadas, hasta los últimos años" [1972:143], y afirma que "en el tema de la etnia, Marx y Engels se redujeron a repetir algunos de los prejuicios muy comunes en los ambientes intelectuales de Europa centro-occidental, sin aportar nada que los aclarara" [Ibíd.:145]. Bagú concluye su reflexión sosteniendo que el

gran cuadro conceptual de Marx y Engels quedó incompleto, porque es imposible llegar a una comprensión aceptable de la naturaleza de la estructura social, sin ubicar dentro de ella la función que cumplen los conjuntos culturales que se expresan por medio de conflictos nacionales, religiosos y lingüísticos: "Sin comprender mucho mejor que hasta ahora los mal denominados problemas judío, irlandés (...) negro o indio, ya no es inteligente seguir suponiendo que se pueda llegar a saber qué son las clases sociales, por qué existen y cuáles son sus verdaderas funciones [Bagú, 1972:145].

Wallerstein y Balibar [1991], explican las tensiones ideológicas del capitalismo a partir de una contradicción 
en el mundo moderno entre el discurso universalista de la fraternidad universal (la igualdad social) y la existencia del racismo y el sexismo. Sostienen que, en tanto el universalismo como doctrina política sólo se ha impulsado seriamente en el mundo moderno, la indagación sobre su origen debe hacerse "en el marco socioeconómico de este mundo" [Wallerstein y Balibar, 1991: 52], considerando que la economía-mundo capitalista "es un sistema basado en la acumulación continua de capital" para lo cual requiere convertir cualquier cosa en mercancías que circulan en el mercado mundial como productos, capital y fuerza de trabajo. Y que el universalismo es "un elemento fundamental de la acumulación de capital", que "permitiría la máxima eficacia posible en la producción de bienes". Específicamente, en términos de fuerza de trabajo, el racismo (y el sexismo) tienen la función de

reducir al mínimo simultáneamente los costes de producción (y por ende los costes que genera la fuerza de trabajo) y los derivados de los problemas políticos, y por tanto, reducir al mínimo posible simultáneamente, y no eliminar, ya que es imposible, las reivindicaciones de la fuerza de trabajo. El racismo es la fórmula mágica que favorece la consecución de ambos objetivos [Wallerstein y Balibar,1991: 56].

Esto es lo que ocurrió, según Wallerstein, por ejemplo, cuando los europeos, al llegar al Nuevo Mundo, empezaron a eliminar con la enfermedad y la violencia a los pueblos aborígenes, ya que, con la defensa de Bartolomé de las Casas, se reconoció que los indios eran seres humanos y debían ser regidos por el derecho natural, razón por la cual no podían ser eliminados de modo indiscriminado, sino ser salvados (convertidos al universalismo cristiano). Así, "al estar vivos y presumiblemente en vías de conversión, podían ser integrados en la fuerza de trabajo, desde luego según el nivel de sus aptitudes, lo cual quería decir en el 
más bajo de la jerarquía profesional y salarial" [Wallerstein y Balibar, 1991: 57]. Operativamente, el racismo se ha presentado bajo la forma de "etnificación" de la fuerza de trabajo, estableciendo una "jerarquía de profesiones y de remuneraciones asociada a ciertos criterios supuestamente sociales" (religión, lengua, pautas culturales) o genéticos (color de la piel) [Wallerstein y Balibar, 1991: 55]. Por tanto, en la mirada de los autores, el racismo es un elemento que tiene una gran importancia en las relaciones de mando y obediencia respecto del control del trabajo, y tiene como objetivo reducir los costos de producción y las capacidades reivindicativas y políticas de los trabajadores. Por tanto, el racismo sería un mecanismo creado por el capitalismo para desvalorizar la fuerza de trabajo con el fin de maximizar la acumulación de capital.

Por su parte, Quijano tiene un enfoque diferente respecto del papel de la raza, sostiene que tal categoría no sólo es importante en el capitalismo, sino en el patrón de poder capitalista en su conjunto. Esto es, la raza es un elemento central en la clasificación social, junto con la fuerza de trabajo y el sexo. En este sentido, la raza es un criterio fundamental en la distribución de las personas en el conjunto de las relaciones de poder en el patrón de poder colonial-moderno, en tanto base de la dominación social, jerarquizador de las relaciones de trabajo y como modo de producción de conocimiento.

Desde la conquista de América, al sexo, edad y fuerza de trabajo se le sumó el fenotipo como elemento para la clasificación social. El sexo y edad, dice Quijano [2007a: 118]:

son atributos biológicos diferenciales, aunque su lugar en las relaciones de explotación/dominación/conflicto está asociado a la elaboración de dichos atributos como categorías sociales. En cambio, la fuerza de trabajo y el fenotipo no son atributos biológicos diferenciales. El color de la piel, la forma y el color del cabello, de los ojos, la forma y el tama- 
ño de la nariz, etc. no tienen ninguna consecuencia en la estructura biológica de las personas y, ciertamente, menos aún en sus capacidades históricas. Y, del mismo modo, ser trabajador "manual" o "intelectual" no tiene relación con la estructura biológica. En otros términos, el papel que cada uno de esos elementos juega en la clasificación social, esto es, en la distribución del poder, no tiene nada que ver con la biología, ni con la "naturaleza". Tal papel es el resultado de las disputas por el control de los ámbitos sociales.

Quijano resalta que el poder, todo poder, requiere de un mecanismo subjetivo para su reproducción, por lo que se requiere de la producción social de ciertas categorías que identifican lugares y funciones en las relaciones de poder, presentándolas como nombres de fenómenos naturales, más allá de si tengan alguna referencia real en la naturaleza. Sostiene que, mientras la producción social de la categoría género es muy antigua en la historia social, la correspondiente a la categoría raza (basada en el fenotipo) es reciente, y su influencia en la clasificación social en las relaciones poder se inicia en América y la mundialización del patrón de poder capitalista.

A diferencia de Wallerstein, para Quijano, la producción de la categoría raza, no solo tiene una justificación económica, de explotación de la fuerza de trabajo, sino ante todo, como un mecanismo de dominación. Así, sostiene que:

La importancia y la significación de la producción de esta categoría para el patrón mundial de poder capitalista eurocéntrico y colonial/moderno, difícilmente podría ser exagerada: la atribución de las nuevas identidades sociales resultantes y su distribución en las relaciones de poder mundial capitalista, se estableció y se reprodujo como la forma básica de la clasificación social universal del capitalismo mundial, y como el fundamento de las nuevas identidades 
geo-culturales y de sus relaciones de poder en el mundo. Y, así mismo, llegó a ser el trasfondo de la producción de las nuevas relaciones intersubjetivas de dominación, y de una perspectiva de conocimiento mundialmente impuesta como la única racional. La racialización de las relaciones de poder entre las nuevas identidades sociales y geo-culturales fue el sustento y la referencia legitimadora fundamental del carácter eurocentrado del patrón de poder, material e intersubjetivo. Es decir, de su colonialidad. Se convirtió, así, en el más específico de los elementos del patrón mundial de poder capitalista eurocentrado y colonial/moderno, y penetró cada una de las áreas de la existencia social del patrón de poder mundial, eurocentrado, colonial/moderno [Quijano, 2007a: 119].

De este modo, la idea de raza fue central para establecer una clasificación social universal jerárquica, legitimadora de las relaciones de dominación, de la distribución de la población en las relaciones de poder, entre ellas, respecto del control del trabajo, así como de una perspectiva de conocimiento, el eurocentrismo, considerada la única racional y científica. Por tanto, a partir de la idea de raza, los europeos blancos, considerados como "superiores" ante los no europeos y no blancos, calificados como "inferiores”, se asignaron para sí el control del trabajo y el trabajo asalariado, dejando para los otros, formas de trabajo no asalariado (esclavitud, servidumbre, reciprocidad y pequeña producción mercantil simple).

\subsubsection{BALANCE DE LA REVISIÓN DEL CONCEPTO}

COLONIAL-MODERNO DE TRABAJO: LA COLONIALIDAD

DE TODAS LAS FORMAS HISTÓRICAS DE TRABAJO

A lo largo de este recorrido por diferentes autores y distantes épocas y espacios, se ha tratado de establecer cómo 
se constituyó el concepto dominante colonial-moderno de trabajo, en tanto trabajo asalariado, homogéneo y abstracto. La idea central que se desprende de esta gratificante odisea investigativa es que en la colonialidad-modernidad, la producción por el pensamiento dominante del trabajo como categoría social tuvo como objetivo legitimar una manera específica, requerida por el poder capitalista, moderno y colonial, de producir riqueza: el trabajo abstracto y homogéneo a partir del trabajo asalariado, que produce valor de uso y valor de cambio, al mismo tiempo. Se trata de un tipo muy específico de trabajo, asalariado, del trabajo productivo que tiene como característica exclusiva la producción de plusvalor. Esta categoría social se refiere al trabajo manual con apoyo de máquinas que multiplican su productividad, esto es, el trabajo típicamente industrial.

La producción de esta categoría social significó otorgarle al trabajo manual, relevancia y reconocimiento social que no había tenido en el mundo anterior al de la colonialidad-modernidad. Desde la aparición de las relaciones de poder, esto es, de dominación, explotación y conflicto, en los albores de la historia humana, la actividad manual destinada a la producción agropecuaria, o sea, a la producción de los satisfactores básicos, fue estigmatizada desde una visión aristocrática que la calificó como despreciable e indigna. Fue Aristóteles el primero que en el pensamiento occidental definió al trabajo manual como una actividad indigna porque impedía al hombre vivir de manera autónoma, sin preocupaciones por satisfacer sus necesidades básicas. También fue el primer pensador que atribuyó a la fuerza de trabajo manual un lugar subordinado en la clasificación social a partir de su creencia en la desigualdad natural entre los hombres, al sostener que las labores manuales correspondían a seres humanos inferiores, faltos de raciocinio y capacidad argumentativa, corporalmente fuertes, y destinados, por tanto, a la obediencia y la labor física. La desigualdad natural fue el argumento central 
que justificó la esclavitud en la Grecia antigua, un tipo de control del trabajo que permitió a un sector reducido de habitantes de la polis dedicarse a la filosofía y a la política, en tanto ciudadanos, situación que fue negada a los esclavos.

Con el cristianismo, y a partir de la "caída" de Adán y Eva, a las actividades manuales orientadas a la satisfacción de las necesidades se les atribuyó una pesada carga, una condena divina: "comerás con el sudor de tu frente", que se mantuvo durante la Edad Media, hasta el siglo xv. Esta condena, en la medida en que la iglesia católica se institucionalizó y burocratizó, y se hizo sostenedora y aliada del poder feudal, fue una carga para los campesinos europeos, quienes estaban clasificados de manera subordinada y para producir el sustento material del clero y la aristocracia. San Agustín, y sobre todo, santo Tomás de Aquino, legitimaron tal clasificación basándose decisivamente para ello en las ideas aristotélicas de la desigualdad natural entre los hombres.

Serían los cristianos protestantes quienes le dieron un giro dramático a la visión del trabajo manual, estableciendo su dignidad social a partir de la noción de vocación, de modo que el trabajo manual se constituía, a partir de su laboriosidad y de una vida austera del trabajador, en la vía para la salvación de las almas. Tanto Lutero como Calvino rechazaban las jerarquías eclesiásticas, la corrupción de la Iglesia y la mercantilización del perdón divino (la venta de las indulgencias), abogando por una relación de igualdad entre los creyentes respecto a Dios. No obstante, ninguno de los dos cuestionó la clasificación social ni la dominación y explotación de los campesinos en su época, porque se trataban de temas "mundanos".

Entre los siglos XVI y XVIII, desde la constitución del capitalismo a escala mundial y la emergencia del proyecto de la modernidad, pasando por Locke y Genovesi, el concepto de trabajo manual sería engendrado, en asociación con la razón instrumental, como un medio para acumular 
riqueza y poder. Así, el trabajo manual concebido por los protestantes como un medio para lograr la gracia divina, terminó siendo considerado por Adam Smith tan sólo como un acto mecánico, despojado de todo contenido religioso y ético. Se trataba pues, de un concepto de trabajo desalojado de su contexto histórico y cultural, pensado desde un movimiento inexorable del devenir histórico en términos evolucionistas y civilizatorios, "desde Europa" para el mundo entero y según las necesidades del patrón de poder colonial, moderno, capitalista y eurocentrado. Se trataba de un tipo de trabajo que Adam Smith, según un criterio de cientificidad eurocéntrico, definió como productivo, creador de valores de uso y de cambio a la vez, un trabajo abstracto, que definía la riqueza como resultado de relaciones sociales asimétricas, borraba de lo económico otras formas de trabajo no asalariadas, porque se consideraban arcaicas, precapitalistas y pertenecientes a "pueblos sin historia". Un tipo de concepto de trabajo que escondía la colonialidad, ya que presentaba la clasificación social, el lugar del trabajo, el tipo de trabajo, el pago (o no pago) y la cantidad pagada al trabajador, como algo que se daba de manera "natural", por razones puramente económicas. En este enfoque, eurocéntrico y colonial, la clasificación social jerárquica a partir de la idea de raza, esto es, la colonialidad, no tenía ningún empacho en percibir a los no europeos como no humanos y salvajes, y en asignarlos a trabajos no asalariados, esto es, sin ningún costo, como la esclavitud y la servidumbre. Si bien, con el tiempo, los no europeos (no blancos) fueron accediendo a trabajos asalariados, siempre lo hicieron en condiciones desfavorables, efectuando los trabajos peores y percibiendo los salarios más bajos, a diferencia de los europeos (blancos). ${ }^{35}$

35 Para estudios contemporáneos en torno a este problema, puede verse: Zabala Argüelles (comp.) [2008], Pobreza, exclusión social y discri- 
Marx hizo una genial contribución a la crítica de la economía política clásica al plantear que la sociedad capitalista era un orden social histórico, modificable, y que la dominación y explotación no eran eternas. En términos del concepto de trabajo, Marx desnudó los mecanismos de la explotación capitalista, esto es, la producción y apropiación de la plusvalía por los capitalistas, proceso que se daba en la esfera de la producción y que era ininteligible desde un análisis de intercambio de equivalentes (fuerza de trabajo por salario) en el ámbito de la circulación. Al mismo tiempo, Marx formuló un profundo cuestionamiento a la "patología industrial", es decir, al amplio proceso de alienación que registraba el trabajo en el capitalismo, que se traducía en una conversión del trabajador en apéndice de la máquina y en la pérdida de su capacidad para controlar su propio trabajo y el sentido de su vida en un sistema que tiende hacia la mercantilización total de la existencia social.

No obstante, el pensamiento de Marx presentaba serias tensiones eurocéntricas asociadas al evolucionismo, a su firme creencia en el progreso y a sus fuertes deudas intelectuales y epistemológicas con Hegel (respecto de la civilización, pueblos con historia y pueblos sin historia) y con Smith, respecto del progreso y de las categorías fundamentales de la economía política clásica (las dicotomías valor de uso-valor de cambio, trabajo productivo y trabajo improductivo, proceso de trabajo-proceso de valorización, desarrollo de las fuerzas productivas-alienación). La visión reduccionista de Marx respecto de trabajo productivo, al asimilarlo sólo al trabajo asalariado creador de valor, condujo a consolidar una visión eurocéntrica en torno del derrotero histórico de la humanidad, creada en Europa, en la que lo civilizado era un tipo de trabajo asalariado, al-

minación étnico-racial en América Latina y el Caribe, Bogotá, Clacso-Siglo del Hombre Editores. 
tamente productivo, vinculado al comercio y la industria. Esta mirada reforzó la deslegitimación eurocéntrica de los otros tipos de trabajo, de tipo no capitalista, signados por el trabajo colectivo y la reciprocidad simétrica, que tenían además, una abrumadora importancia cuantitativa en relación con el trabajo asalariado en el mundo del siglo XIX. Al mismo tiempo, Marx no consideró que la idea de raza fuera decisiva como una categoría utilizada en la clasificación social, no sólo para el capitalismo, sino para el patrón de poder capitalista, colonial-moderno y eurocentrado. Como sostiene Bagú [1972] ni Marx ni Engels problematizaron el hecho de que, a partir de la conquista del Nuevo Mundo, los europeos blancos ocupaban posiciones de mando, mientras que los no europeos, no blancos desempeñaban funciones de obediencia. Según Quijano [2007a, 1998], Marx no pudo entrever que el poder capitalista, desde el siglo xVI, tenía como rasgo distintivo la colonialidad del poder a partir de la clasificación social jerárquica basada en la raza, a la que se debían añadir las de clase y sexo.

La colonialidad del trabajo implicó, además de colocar en un lugar privilegiado al trabajo asalariado, la invisibilización de todas las otras formas históricas de control del trabajo (esclavitud, servidumbre, reciprocidad y pequeña producción mercantil simple), las que desempeñaron (y desempeñan) un papel fundamental en la constitución y reproducción del capitalismo mundial, mostrando que el capital las articula de manera jerarquizada para extraer los excedentes del trabajo. El capital coexiste con estas otras formas productivas ${ }^{36}$.

36 En este sentido, es imprescindible destacar el trabajo femenino orientado a la producción y reproducción de la vida en sentido amplio [Federici, 2013]. Desde la perspectiva de la colonialidad del poder no se han efectuado discusiones teóricas respecto del trabajo femenino y las formas históricas de control del trabajo. No obstante, el trabajo femenino 
En la actualidad existe una crisis, no del trabajo, sino del trabajo asalariado, a raíz de los cambios registrados por el capitalismo: desempleo estructural asociado a la sustitución creciente de trabajo vivo por trabajo acumulado, a la derrota política de los trabajadores y al predominio del capital financiero en el mundo del capital. Hay una crisis del trabajo asalariado y un resurgimiento de otras formas de trabajo, entre ellas, la esclavitud y la servidumbre, así como de la reciprocidad y la pequeña producción mercantil simple.

Es importante que tratemos de desmontar la idea eurocéntrica del trabajo asimilado al trabajo asalariado, que deslegitimiza las otras formas de trabajo, que se ha interiorizado en el imaginario social y marca pautas de acción que están dejando de tener bases históricas reales, para prestar atención a otras formas de trabajo, no verticales ni fundadas en la explotación, sino en la reciprocidad, que van surgiendo como parte del nuevo horizonte de sentido histórico emergente: la defensa de la Casa Común, la Madre Tierra, denominado Buen vivir, a partir de los movimientos indígenas. Sus prácticas, ya en despliegue, pueden contribuir a definir otras formas de trabajo, donde éste sea parte de la vida y no la razón de vivir.

Finalmente, es importante plantear la discusión de cómo se elabora y se impone, desde las relaciones del poder, la idea de trabajo intelectual, ubicado jerárquicamente por encima del trabajo manual, y cómo se impone la idea del ocio como no trabajo, teniendo en cuenta que para los griegos el ocio era precisamente la no dependencia de las necesidades básicas y la posibilidad de dedicarse a la reflexión, deliberación, contemplación y a la política.

puede ser parte de la reciprocidad, es decir, de intercambios materiales y simbólicos que no pasan por el mercado, entre sujetos iguales. 


\section{Reflexiones finales: hacia la descolonialidad del trabajo y el Buen vivir}

Antes de concluir esta revisión de cómo se fue creando el concepto de trabajo, trabajo manual-asalariado, articulado con otras formas de control del trabajo como una categoría social y destacando el periodo histórico de la colonialidad-modernidad, es importante precisar que el trabajo puede diferenciarse de la actividad y del empleo. Según diversos autores, el rasgo fundamental que interesa resaltar es que el trabajo es una acción instrumental respecto de la naturaleza, buscando su transformación y dominio.

$\mathrm{Al}$ respecto, Friedman sostiene que las definiciones baconiana, marxista, y en general, todas las definiciones de trabajo que ponen el acento sobre la transformación de la naturaleza por el hombre, implican una finalidad esencial. La transformación de la naturaleza se orienta hacia un fin: su dominio por el hombre, su "amo y poseedor" [Descartes], la asimilación de su materia (transformada en objetos y en productos) a necesidades humanas [Friedman, 1992: 14]. Esta visión de exterioridad del hombre respecto de la naturaleza y de la necesidad de dominarla es una característica central del pensamiento occidental, la misma que se deriva del dualismo cartesiano, de la separación razón-mente-cuerpo y del dualismo sociedad-naturaleza, y sigue presente entre intelectuales que critican la asimilación del trabajo al trabajo asalariado industrial, al trabajo abstracto, el trabajo como mercancía susceptible de ser dividido, que no se cumple por sí mismo, por placer, para satisfacer una necesidad personal de quien lo ejecuta, sino que se lleva a cabo para obtener un ingreso salarial 
mediante el contrato de trabajo, y entregar su producto al patrón. Neffa [1999: 7], destaca que dichos intelectuales se orientaron hacia una reconceptualización del trabajo "como la actividad gracias la cual los seres humanos se descubren, toman conciencia y se construyen a sí mismos, y establecen relación con los demás, porque devienen dominadores de la naturaleza y constructores del mundo".

De este modo, es posible afirmar que el trabajo en la colonialidad-modernidad es instrumental, ya que busca el dominio de la naturaleza, pero también es instrumental respecto del otro, porque responde a relaciones de mando y obediencia verticales, y a una concepción colonial del otro, en tanto inferior en términos raciales y de naturaleza, ideas que sustentan la explotación del "hombre por el hombre".

Es importante resaltar que a lo largo de esta investigación al hablar de trabajo nos hemos referido de manera específica al manual y al asalariado (trabajo manual asalariado), como equivalente, desde el lente eurocéntrico, del trabajo en general que invisibiliza otras formas de trabajo. A fines del siglo xix era claro que la industrialización en Europa iba haciendo creciente lo que Marx llamó la patología industrial, es decir, la alienación del trabajador manual asalariado concebido como apéndice de la máquina y creador de riqueza, riqueza que debía extraérsele aun a costa de dejarlo sin humanidad y sin vida. Más de un siglo después, el trabajo manual asalariado ha entrado en abierta crisis con el crecimiento del desempleo estructural, el mismo que se ha visto fortalecido por el predominio de la rama financiera del capital en el capitalismo. Esta crisis del trabajo manual asalariado se ha desatado teniendo como telón de fondo la crisis del entero patrón de poder colonial, moderno y capitalista, y de la modernidad misma, como proyecto intersubjetivo de liberación humana a partir de la razón.

Es necesario, por tanto, dirigir nuestros esfuerzos hacia una resignificación del trabajo. ¿Cómo orientar esa 
búsqueda? Pueden existir dos caminos: uno, ya explorado en las últimas décadas, dentro de la propuesta de la modernidad-colonialidad e inspirado en el progreso-desarrollo. Otro, partiendo de una nueva intersubjetividad que surge de los diversos movimientos sociales, principalmente indígenas, y que están conformando un amplio movimiento de la sociedad. La primera vertiente ya no tiene sustento, pues es la modernidad en sí misma, como proyecto racional de liberación humana, la que ha entrado en crisis. No se trata sólo del derrumbe de sus dos versiones, es decir, de la razón instrumental, asociada al poder, al capitalismo y a la colonialidad, y de la razón histórica, vinculada a la liberación, sino del proyecto liberador basado en la razón, pues está centrado en lo humano, y por tanto, desgajado del árbol de la vida. La modernidad histórica es, como ya se ha comentado en la parte introductoria de este libro, la modernidad-colonialidad que niega la existencia de la alteridad, separa razón y mente de cuerpo, clasifica a la población de manera jerárquica a partir de un constructo mental (la raza) y exterioriza a la naturaleza.

En la modernidad histórica, en la modernidad-colonialidad, la razón está subordinada al poder, a la dominación y explotación humana y de la naturaleza. La modernidad-colonialidad tiene en el progreso-desarrollo un poderoso imaginario que naturaliza la opresión humana y de la naturaleza, establece un devenir histórico, social e institucional único y legítimo (el europeo), mismo que sirve de referencia y punto obligado de llegada para todos. Dentro de este imaginario eurocéntrico, lo económico está asociado al trabajo asalariado, a la eficiencia costo-beneficio y a la concepción del tiempo medido, a la valorización monetaria del esfuerzo laboral en términos de unidades de tiempo (hora, día). El trabajo está cartesianamente desgajado de la vida, instrumentalizado, alienado y subordinado, y el trabajo de los no blancos está desvalorizado. 
No obstante el desempleo estructural y el desmoronamiento de la civilización occidental, en los círculos de poder se continúa hablando de reformas estructurales, inversión, crecimiento económico y empleo. Continúa colocándose el trabajo asalariado como eje de estructuración social, de reproducción socioeconómica, de identidad y reconocimiento social. Esta visión, que está muy presente en sectores intelectuales, permea también en amplios segmentos sociales populares, que guían sus acciones con el imaginario del progreso-desarrollo, lo que demuestra el poder de la subjetividad para producir sentido y encaminar la acción social cuando la materialidad, en este caso, del trabajo asalariado, se encuentra en una profunda crisis. Esto evidencia la colonialidad del empleo, del trabajo manual asalariado, en extendidos sectores de la sociedad, colonialidad que se extiende en la invisibilización de otras formas históricas de control del trabajo.

Ante la situación de crisis del trabajo manual asalariado, dentro de un debate amplio respecto de los cambios en el capitalismo desde los años ochenta, un importante sector de intelectuales críticos del capitalismo y de la opresión de los trabajadores ha planteado una ampliación importante, pero insuficiente, de la redefinición del concepto de trabajo.

Se trata de reconocer la legitimidad de otras formas de trabajo que no se ajustan a la imagen dominante en la que trabajo equivale a empleo, la cual se impuso desde hace, por lo menos, un siglo y medio: El "trabajo manual-asalariado" industrial, con derechos legales establecidos en el marco del Estado-nación. Estas otras formas se refieren a diferentes modalidades de trabajo para obtener un ingreso de manera dependiente, mediante la venta de la fuerza de trabajo en la producción inmaterial y en la actividad de servicios, donde convergen el patrón, el trabajador y el usuario-cliente; o de manera independiente, en la que se encuentran el trabajador autoempleado y el cliente [De 
la Garza, 2010]. Esto es, se da paso a la aceptación de que no sólo el "trabajo manual-asalariado" de tipo industrial es productivo, situación que se negó al elaborarse la categoría social de trabajo productivo, como único creador de riqueza, por la Economía política "clásica", por lo que se identifica como "trabajo clásico". ${ }^{1}$

Esto evidencia de modo claro cómo la producción de conocimiento en la modernidad era a la vez colonialidad, pues la idea de trabajo se construyó negando la existencia ontológica y epistemológica de otras historias y culturas, y de otras formas de trabajo no mercantiles, que pertenecían a los "pueblos sin historia".

Esta importante ampliación del concepto de trabajo no reconoce las formas basadas en la solidaridad y reciprocidad (intercambio de trabajo y de fuerza de trabajo por fuera del mercado) características del mundo indígena, especialmente en zonas rurales, ni tampoco las formas asociativas que van surgiendo de manera creciente en ámbitos urbanos, a consecuencia de la crisis estructural del empleo y de búsquedas de otros modos de vida. ${ }^{2}$ Se trata de las cooperativas y una miríada de grupos que se autodenominan "colectivos" en los que se enfatiza la autonomía, la autogestión y la búsqueda de trabajo digno mediante la práctica del trabajo colectivo. ¿Por qué ocurre esta falta de reconocimiento del trabajo solidario

1 Al respecto ver De la Garza (2010: 113).

2 Sin embargo, es importante establecer un diálogo entre la descolonialidad del trabajo con los esfuerzos que se están desplegando desde la Sociología del Trabajo que deja de lado el enfoque estructuralista y recupera la agencia y la subjetividad en el estudio de lo laboral, con la misma propuesta del Concepto ampliado de trabajo, así como con los Nuevos estudios laborales que proponen un abordaje multisdisciplinario y relacional de lo laboral. Este diálogo es importante porque se trata de encontrar puntos comunes entre las diferentes perspectivas a partir de las relaciones de poder en el patrón de poder colonial, moderno, capitalista, mundial y eurocentrado. Mi agradecimiento a Carlos Clemente Martínez por estas lúcidas sugerencias. 
y recíproco? ¿Porque tal vez, desde una perspectiva evolucionista se considera que este tipo de trabajo es parte del pasado y por tanto ya no tiene y no puede tener lugar en el presente ni en el futuro? ¿Porque es difícil sino imposible imaginar una sociedad regida por relaciones solidarias, es decir, en la mirada de Polanyi, una sociedad donde el eje de integración social sea la solidaridad? ¿Porque tal vez se considera que, en el mejor de los casos, estas formas de organización del trabajo pueden existir, pero únicamente de manera subordinada a las relaciones sociales de poder dominantes, algo así como en un "Tercer Sector" en el que se practiquen relaciones sociales no mercantiles, acotadas en ciertos ámbitos de la sociedad?

Una resignificación descolonial del concepto de trabajo debe abrevar de los aportes mencionados producidos desde los márgenes de este mundo vertical, racista, instrumental, destructor de la Madre Tierra y de la vida, del mundo de la modernidad-colonialidad en abierta crisis. Pero, sobre todo, la inspiración para resignificar y, en este caso, para avanzar en la descolonialidad del concepto de trabajo, es abrir nuestros sentidos hacia lo nuevo, aunque incierto y no definitivo que está emergiendo, es decir, un nuevo sistema histórico, el Buen vivir, caracterizado por combinar racionalidades liberadoras y solidarias, por una intersubjetividad relacional, en la que se reconozca la diferencia sin que ella sea fuente de desigualdades y jerarquías, y que asocie el saber científico como el saber no científico en la producción de conocimiento [Germaná, 2011].

Esta propuesta emergente de otro sistema histórico tiende a asociarse con ciertas imágenes que delinean (pero no fijan) sus contornos en referencia a la igualdad social y a la relacionalidad entre diversos que establecen entre ellos relaciones de reciprocidad, complementariedad y democracia. El trabajo como una actividad para la vida, llevada a cabo considerando el tiempo cíclico y el tiempo 
medido, el trabajo no despreciado, sino apreciado. En este sentido, Van Kessel y Condori [1992], y Medina [2001] contribuyen a formular algunas ideas respecto del trabajo en su versión indígena.

Para Van Kessel y Condori [1992], el trabajo desde la mirada occidental es una actividad económica que permite a la persona manipular y transformar su mundo, con la finalidad de obtener los bienes necesarios para su subsistencia, además de conformar parte de su identidad al avalar que cumple con un deber fundamental. En la visión andina, por otro lado, el trabajo implica garantizar la armonía y la vida en el mundo mediante una estrecha relación entre actividad y espiritualidad, todo esto en comunidad. Afirman los autores que es necesario respetar la tecnología autóctona, pues ha estado inmersa desde hace cientos de años en un proceso de adecuación que asegura el respeto a los valores y las tradiciones culturales que la rodean, apoyando así al proyecto emancipatorio de la comunidad donde surgió. El trabajo, en estas condiciones, es una especie de diálogo con el mundo, que en el caso andino, está formado por tres comunidades: la humana, la divina y la naturaleza. Para mantener el equilibrio entre ellas cada actividad económica se enmarca en rituales de producción, dotando de una dimensión simbólico-religiosa a aquello que, desde la ideología occidental, sería considerado como puramente empírico. En la concepción andina, ni la masividad ni la uniformidad del producto son el objetivo del trabajo, la particularidad de la producción se utiliza a favor, destinando las variaciones a subsidios o reparos para que nada se pierda y todas las necesidades queden cubiertas. Se toma en cuenta, además, que el comportamiento de cada miembro hacia la vida repercutirá en el resultado final del trabajo colectivo, es decir, hay un código ético único que rige todos los aspectos de la vida, no se requiere una ética de trabajo por separado. Es por esto que la competencia tampoco nece- 
sita de una regulación adicional, consiste simplemente en una demostración de las habilidades y capacidades para ayudar a sostener a la comunidad y la familia.

Los siguientes fragmentos pueden ser útiles para hacer el contraste entre las dos visiones de trabajo.

Primero, el lugar del trabajo en la vida. Así:

en la cultura occidental entendemos el trabajo como una actividad económica. Según esta visión, el trabajador se sacrifica para arrancar su existencia, su riqueza y bienestar material del medio natural que le circunda (...) En la visión occidental, además, "la naturaleza es el conjunto de los recursos naturales con que el hombre ha de trabajar, transformar y humanizar al mundo" [Kessel y Condori, 1992: 3].

Mientras que en la cultura occidental el trabajo es una actividad productiva, separada de la vida en su conjunto, y la naturaleza es una fuente de recursos, en el mundo indígena el trabajo es la reproducción de la vida en su conjunto en armonía con la naturaleza. De este modo, "el hombre andino tiene una visión distinta del trabajo (...) El mundo es un todo vivo (...) su trabajo es cultivar la vida del mundo en la chacra, el ganado, la casa (...) Concretamente, la chacra es fuente de vida divina y sus frutos son vivos (...) El trabajo es más que una actividad productiva, es un culto a la vida." [Ibíd.: 4]. Y continúan: "El trabajo es, para el andino, una actividad productiva y un culto sagrado en que el hombre se relaciona con el mundo ayllu en sus tres dimensiones: la comunidad humana, la comunidad divina y la comunidad natural silvestre (...) con el objetivo de cultivar la vida del todo y sus integrantes" [ Ibíd.: 12].

En segundo lugar, el trabajo es llevado a cabo por todos los miembros de la familia y tiene como principio básico la reciprocidad: 
hombres y mujeres, y aun los hijos mayores, todos participan en la labor (...) se recurre al ayni (...) prestaciones que se intercambian y son contabilizadas para ser devueltas en la misma forma y cantidad (...) el dueño recibe servicios que el día antes o después devolverá con el mismo trabajo (...) se ayudan tíos paternos, sus hijos y hermanos (...) la familia debe ofrecer un sólido frente ante el mundo [Kessel y Condori, 1992: 24].

El filósofo boliviano Medina, por su parte, dice que, desde la visión occidental, la naturaleza es vista como exterioridad, y el trabajo manual como algo despreciable. De este modo, afirma, respecto de la naturaleza, que "desde el lado griego, como recuerda Hannah Arendt, en $\mathrm{La}$ condición humana, la noción de la Buena vida está ligada a la vida en la polis (...) [identifica] a la naturaleza como opuesta a la cultura”. El autor sostiene, además que “el ideal griego de la Buena Vida está, así mismo, vinculado a la actividad contemplativa, al desarrollo del intelecto, del cuerpo y de las artes, a la política y a la posibilidad de disponer de tiempo libre para hacer lo que le espíritu demande [Medina, 2001: 32].

Respecto al trabajo manual, Medina [Ibíd.] reafirma la valoración negativa existente entre los griegos, sosteniendo que "el trabajo manual rebaja la condición humana, por eso está destinado a mujeres, metecos y esclavos que no son considerados seres humanos civilizados". Y el trabajo es una acción para la reproducción de la vida (humana y no humana), algo cósmico; en su conjunto, "el cosmos es entero, no quebrado por la oposición materia/espíritu; ni desintegrado por la contradicción religión-tecnología y el divorcio entre ética y economía; no partido por la separación del hombre respecto de su trabajo y por la enajenación del producto de su trabajo” [Ibíd.:34].

El trabajo indígena es "contemplación, meditación y celebración y la Chacra (...) punto de encuentro, diálogo 
e intercambio de las tres comunidades que componen el Ayllu cósmico andino" [Medina, 2001:35]. En este sentido, el trabajo indígena está asociado al rito y al juego: "los amerindios han ligado trabajo con juego a través de la ritualidad, que azuza una competitividad no antagónica sino de sinergia, sumamente importante, como insumo para la construcción de una civilización cualitativa" [Ibíd.].

En síntesis, a diferencia de la visión occidental [Simon, 1987; Neffa, 1999], el trabajo en el mundo indígena no tiene una finalidad instrumental, ya que es parte de la vida y de la búsqueda de los equilibrios cósmicos, no tiene una ética específica, se basa en la reciprocidad, y es trabajo y juego al mismo tiempo. Éstas son algunas ideas provenientes de la cultura aymara que pueden contribuir a perfilar la búsqueda de una redefinición de trabajo. Por supuesto que es necesario ahondar en el estudio de este tipo de visiones, y al mismo tiempo ubicarlas en el tiempo histórico en que vivimos; uno en el que el mundo está dominado por el patrón de poder colonial, moderno y capitalista, en el que las resistencias contra tal patrón de poder deben hacerse desde la vida cotidiana y construyendo otro tipo de poder, el democrático.

En este sentido, la redefinición del trabajo se encuentra en una lucha cotidiana entre dos estructuras de poder opuestas, una basada en la racionalidad instrumental, y la otra en racionalidades liberadoras-solidarias. Y es la resistencia, la construcción de otra vida a pesar de la presencia del poder capitalista, lo que articula todos los esfuerzos y pone en tensión, en este caso, el despliegue de otras economías y otras formas de concepción del trabajo. Este es el caso del zapatismo, para el cual el trabajo colectivo es central. En palabras de Zibechi [2015], "los trabajos colectivos son el motor de la autonomía”. En efecto, los trabajos colectivos son el corazón del movimiento. Comenzaron mucho antes del levantamiento. Según varios testimonios, ya en 1988 se hacían trabajos 
colectivos en la clandestinidad, y se llevaban a cabo en tres niveles: las comunidades y en los municipios autónomos o en los Caracoles. Hay trabajos de mujeres y varones; se practican en el área de salud, en las escuelas y las secundarias. Son la base de la autonomía, en todas y cada una de las esferas del zapatismo. Los trabajos colectivos de los zapatistas son el núcleo duro de la autonomía. Estos trabajos tienen dos dimensiones: material y subjetiva. Gracias a los trabajos colectivos los zapatistas construyeron su mundo: los Caracoles, en donde funcionan las juntas de Buen Gobierno; los municipios autónomos, todos los espacios en que funcionan las escuelas y las secundarias, las salas de salud, las clínicas y los hospitales, las tiendas y los cientos de emprendimientos comunitarios. Por eso son el motor, porque permiten levantar y sostener día a día el mundo nuevo. Ser zapatista es sinónimo de hacer trabajos colectivos. Sin estos trabajos, en los que participa toda la comunidad, no habría autonomía, porque deberían depender de otros, del Estado, de la solidaridad nacional o internacional. Aunque la solidaridad ha hecho importantes contribuciones materiales, el trabajo concreto corresponde a las bases de apoyo" 3 .

En esta lucha por la descolonialidad del trabajo, no tendría sentido una mirada unilateral centrada en los aportes de los movimientos y culturas indígenas, pues hay que ensanchar la búsqueda, evaluando los aportes de otras perspectivas, entre ellas, del anarquismo, que se opone al trabajo instrumental y destaca la horizontalidad, la creación y el juego, así como la propuesta de Marx de los dos reinos, el de la necesidad y el de la libertad, en los que el trabajo es obligación y disfrute, respectivamente; acerca de este último caso, dice Diez [2014: 428] que se trata de "un impreciso trabajo libre, enteramente al servicio de la

${ }^{3}$ Del trabajo colectivo en el zapatismo, ver Marañón [2014a]. 
plena expresión y realización de las diferentes cualidades y dimensiones de los seres humanos". En esta vertiente, Noguera [2002: 151] propone que en Marx se pueden encontrar tres dimensiones del trabajo: trabajo como actividad orientada a un fin (cognitivo-instrumental o teleológica), trabajo como interacción social y comunicación (práctico-moral, o social) y trabajo como autoexpresión práctica del ser humano (estético-expresiva).

Black [s/f], desde el anarquismo, plantea la abolición del trabajo, porque el trabajo sería la causa de casi toda la miseria de este mundo, porque el trabajo es resultado de la dominación y es una acción forzada. Sostiene que su "definición mínima del trabajo es labor forzada", es decir, producción impuesta. Ambos elementos son esenciales. El trabajo es producción impuesta por medios económicos o políticos, por la zanahoria o el látigo (la zanahoria es sólo el látigo por otros medios). Pero no toda creación es trabajo. El trabajo nunca es hecho por amor al trabajo mismo, sino para obtener un producto o resultado que el trabajador, o con más frecuencia, alguien más, recibe del mismo. Esto es lo que el trabajo debe ser. Afirma que rechazar el trabajo no significa que tenemos que dejar de hacer cosas, sino crear una nueva forma de vivir basada en el juego; en otras palabras, una convivencia lúdica, comensalismo, o tal vez, incluso arte, basada en una aventura colectiva, en alegría generalizada y exuberancia libremente interdependiente. El juego es voluntario, y lo que se espera no son resultados, siendo la recompensa esperada la experiencia que se obtiene de la actividad misma.

Black sostiene que puede encontrarse en las sociedades primitivas contemporáneas una visión distinta del trabajo, basada en una concepción de balance en la vida, y por ello trabajan un día sí y otro no, y el día de descanso es destinado a "recobrar el poder y salud perdidos". Esta visión también estaba presente en Europa, hasta el siglo XVIII, cuando empezó a imponerse la disciplina del 
tiempo capitalista, suprimiendo progresivamente los días festivos y de reposo. Basándose en Shalins, Black destaca la intermitencia en el trabajo, la abundancia del tiempo libre y ejercicio de una actividad intelectual y física, que cumplían los cazadores y recolectores, satisfaciendo la definición schilleriana de juego, entendido como la única ocasión en que el hombre realiza su completa humanidad al dar completa expresión a ambos lados de su naturaleza: pensar y sentir. El juego y la libertad debían ser, en lo referente a la producción, coextensivos.

Si retomamos los aportes de Marx del reino de la necesidad y la libertad, del juego en el sentido anarquista que implica la expresión del pensar y sentir de los humanos, y las prácticas indígenas que consideran el trabajo como articulado a la armonía y la vida en el mundo, por medio de la asociación entre actividad y espiritualidad, podríamos tener un punto de partida para una definición descolonial de trabajo, que parta, como afirma Ceceña [2014: 17-18]:

de entender la producción y el trabajo como espacios de libertad y de goce en los que se establece la relación con otros sujetos (el maíz, las aves, etcétera). Se produce como un acto social y no económico, ya que la producción y el trabajo son un ejercicio de reafirmación de la vida, lo que implica también el ejercicio y la recreación de la politicidad, y no un mal necesario o un simple medio para garantizar la sobrevivencia. El trabajo no es equivalente al empleo, la vida no se resuelve con empleo sino reinventando la complementariedad. Es decir, la recuperación del trabajo como acto social e intersubjetivo es en sí misma contradictoria con la manera capitalista de entender la producción o el trabajo productivo. El trabajo que cuida y reproduce la vida considera a esta en un sentido amplio, no se reproduce un tipo de vida sin las otras; es preciso regenerar el entramado completo de la vida para dar condiciones de futuro a la misma humanidad. 
El trabajo en la visión indígena no puede reducirse a un hecho económico, sino que es un elemento para reproducir la vida humana y no humana en su conjunto. En este sentido, una visión descolonial de trabajo debe incorporar las actividades que las mujeres cumplen en la producción y reproducción del trabajo y de la vida, pues como afirma Gutiérrez comentando los aportes de Federici al pensamiento feminista, el mundo capitalista no puede ser comprendido a cabalidad - para avanzar en su crítica- si únicamente se miran los bucles de la producción de mercancías, su distribución y consumo, es decir, de lo que suele llamarse reproducción del capital. Hay otro gran ámbito de la vida social que se encuentra más allá, por debajo, adentro, en contra de los incesantes procesos de producción y reproducción del capital: son los múltiples mundos siempre regenerados por los esfuerzos incesantes, hechos sobre todo por mujeres - aunque no únicamente-, por mantener y sostener la vida, por ampliar sus posibilidades de gozo y disfrute, por reproducir material y simbólicamente la vida humana y no humana, día tras día, año tras año, generación tras generación [Gutiérrez, 2015: 171].

Esta definición descolonial del trabajo requiere necesariamente repensar la noción dominante de economía ${ }^{4}$, reconocer la existencia de diversas economías basadas en la reciprocidad ${ }^{5}$, a las que podemos denominar solidaridad económica [Marañón, 2016a y 2016b). El trabajo descolonial tendría que estar asociado a otro sistema histórico que no se apoye en la racionalidad instrumental (medios-fines), sino en racionalidades solidarias y liberadoras,

4 Es necesario discutir qué es lo económico. Braudel [1985] sostiene que lo económico se inicia con el intercambio de mercancías en el mercado, y que las acciones que se centran en el valor de uso se encuentran dentro de la vida material, o no económica. [2014].

5 Respecto de la discusión acerca de la reciprocidad, ver López 
y que tenga como horizonte histórico el Buen vivir ${ }^{6}$. En tanto descolonial, el trabajo se vincula con la solidaridad económica, conjunto de relaciones sociales que tienden a la reciprocidad, a la desmercantilización, a la relacionalidad y al autogobierno, para la satisfacción de las necesidades básicas y la reproducción integral de la vida, desde una acción emancipadora y solidaria entre los humanos con la Madre Tierra. En este sentido descolonial, la solidaridad económica es una forma de control del trabajo no heterónoma que articula tanto a la reciprocidad como a la producción mercantil simple, así como al trabajo femenino orientado a la producción y reproducción de la vida.

En la perspectiva del Buen vivir, la descolonialidad del trabajo puede abrevar de la noción de valor de uso, propuesta por Marx, a condición de alejarse de lo occidental como civilización naturalizada ${ }^{7}$, con sus problemas de produccionismo y consumismo, y de pensar que el modo de vida occidental (moderno-colonial, centrado en el desarrollo-progreso, en la dominación de la naturaleza, y en la clasificación jerárquica de la población a partir de la idea de raza) es la base para instituir una sociedad alternativa ${ }^{8}$.

Si desacoplamos el valor de uso de lo occidental como algo naturalizado y lo articulamos al Buen vivir, habría la posibilidad de pensar en una redefinición de la producción y de las áreas productivas que deberían ser impulsadas y de las áreas productivas que deberían ser suprimidas. En este sentido, afirma Baschet [2014: 80-81], que se trata de eliminar la lógica del valor, de la producción-para-la-ganancia y del trabajo-para-la-sobrevivencia, de lo que se desprende la supresión de armamentos y equipos

6 Acerca del Buen vivir, ver Acosta [2014], Quijano [2011], Marañón [2014b], Germaná [2011] y Marañón y López [2016].

7 Ver la crítica de Lander a la visión de Marx, en Lander [2008]. Y en el apartado 1.3 de este libro.

8 En este sentido, son muy importantes los desarrollos teóricos que hace Echevarría [2001] respecto del valor de uso. 
militares, de la agroquímica, de diversas actividades financieras, actividades burocráticas y de la agroindustria mercantilizada, entre otras. Sería necesario redefinir el consumo. Todo este proceso sería llevado a cabo a partir de decisiones colectivas.

De este modo, una propuesta de definición del trabajo descolonial sería una actividad que conjugue el trabajo y la vida, reinstale la alegría del trabajo basado en la reciprocidad entre los seres humanos y con la Madre tierra, vincule a todos los seres vivos sin jerarquías de sexo-género, de "raza" y económicas; así, y sin relaciones de dominación y explotación, en un horizonte histórico de sentido orientado al Buen vivir. El trabajo no puede ser entendido sólo como una acción encaminada a satisfacer las necesidades básicas, sino a reproducir la vida en su conjunto, razón por la cual debe reconocer la contribución de las mujeres a la producción y reproducción de la vida.

Esta definición descolonial del trabajo, finalmente, debe necesariamente abrevar de las primeras críticas a la modernidad-colonialidad hechas por Guamán Poma de Ayala en el siglo XVII, Ottobah Cuogano, una centuria después y Mariátegui en el siglo xx.

Guamán Poma [1996] muestra que los pueblos indios ya colonizados siguen reproduciendo con dificultades, debido al despojo y desestructuración de sus modos de vida, el trabajo de los días en ambiente de reciprocidad y fiesta. Ottobah [1787], hace una radical crítica a la esclavitud en el capitalismo. Mariátegui, plantea el socialismo indoamericano a partir de las prácticas colectivas que se continuaban reproduciendo en las comunidades indígenas del Perú [Germaná, 1995].

Si esta reflexión en torno a la colonialidad del trabajo es en sí misma una subversión epistémica, es indispensable una lucha en el ámbito de las palabras y las miradas, como sostiene Gustavo Esteva [2013], y discutir cómo mentar el trabajo en una perspectiva descolonizada: ¿hacer? 
En este caminar, caracterizado por la desobediencia epistémica, es importante también plantear el tipo de autoridad colectiva involucrada en la gestión del trabajo. Applebaum [1987], en su texto Aspectos universales del trabajo sostiene que uno de los rasgos organizativos del trabajo es su verticalidad. Su enfoque nos remite, pues, a la visión eurocéntrica de la eterna e inmodificable división de las relaciones de mando y obediencia, entre los que mandan y los que obedecen, y de la reproducción de la institucionalidad estatal para salir "del estado de naturaleza".

A este respecto, es importante destacar la propuesta zapatista de mandar-obedeciendo, como el mecanismo de regulación del trabajo colectivo y de la vida social en su conjunto ${ }^{9}$, de modo que, en palabras de Quijano [2007b], exista una estrecha imbricación entre reciprocidad simétrica en el trabajo y comunidad, entendida esta última como la toma colectiva y horizontal de decisiones. Se trata de senti-pensar y practicar la vida social micro y macro mediante una regulación pública no estatal, con un institucionalidad diferente a la del Estado (nación), porque ésta es el sustento de la dominación y se despliega con una razón instrumental ${ }^{10}$.

${ }^{9}$ Ver, Marañón [2014b].

$10 \mathrm{Al}$ respecto, ver Quijano [1988] y Marañón [2016c]. 



\section{Bibliografía}

Acosta, Alberto [2014], "El Buen Vivir, una alternativa al desarrollo", en Pablo Quintero (coord.), Crisis civilizatoria, desarrollo y Buen Vivir, Buenos Aires, Editorial del Signo.

Aguiló, Antoni [2009], “El concepto de 'poder' en la teoría política contrahegemónica de Boaventura de Sousa Santos: Una aproximación analítico-crítico", en Nómadas. Revista Crítica de Ciencias Sociales y Jurídicas, España, Nómadas, Publicación Electrónica de la Universidad Complutense, (24): julio-diciembre, recuperado de https://goo.gl/XqaMRL

Álvarez-Cienfuegos, Juan [2010], La cuestión del indio: Bartolomé de las Casas frente a Ginés de Sepúlveda. La polémica de Valladolid de 1550, Ciudad de México, UNAM.

Álvarez Lugo, Armando José [2006], “Trabajo y Mundialización, una Mirada Desde la Antropología”, en Ciencias Sociales Online, Universidad de Viña del Mar. Anthony, P.D. [2001], The Ideology of Work, Londres, Routledge.

Applebaum, Herbert A. [1992], The concept of work: ancient, medieval, and modern, Nueva York, The University State of New York Press.

_ [1987], "The Universal Aspects of Work", en H. Applebaum (ed.), Perspectives in Cultural Anthropology, Nueva York, State University of New York Press. Aricó, José [1992], Marx y América Latina, Ciudad de México, Alianza Editorial/Biblioteca Iberoamericana. 
Aristóteles [s/f] Política. Versión pdf. Consultada en http:// descarga-gratis-libros.blogspot.com

Ariza Montañez, Catalina [2005], "Los objetos con alma: legitimidad de la esclavitud en el discurso de Aristóteles y Alonso de Sandoval. Una aproximación desde la construcción del cuerpo", en Revista Fronteras de la Historia, Instituto Colombiano de Antropología e Historia, (10): 139-170, recuperado de https://goo.gl/ $\mathrm{rJz} 4 \mathrm{H} 4$

Arneil, B. [1992], "Natural law and colonialism", en History of Political Thought, 8, (4): 587-603.

Attali, Jacques [1985] Historias del tiempo, Ciudad de México, Fondo de Cultura Económica.

Bagú, Sergio [1972], Diez conceptos fundamentales en proyección histórica, Ciudad de México, Editorial Nuestro Tiempo.

__ [1959], La estructura social de la Colonia, Buenos Aires, El Ateneo.

Baschet, Jerome, [2014], Adiós al capitalismo. Autonomía, sociedad del buen vivir y multiplicidad de mundos, Buenos Aires, Futuro Anterior-NED ediciones.

Black, Joe [s/f], La abolición del trabajo, en Utopía libertaria (blog) recuperado de https://goo.gl/xxDhmY

Braudel, Fernand [1985], La dinámica del capitalismo, Ciudad de México, Fondo de Cultura Económica.

Braudillard, Jean [1973,] El espejo de la producción, Barcelona, Gedisa.

Carr, Edward Hallett [1985], 1917. Antes y después. (La revolución rusa), Madrid, Sarpe.

Ceceña, Ana [2014], "Del desarrollo al 'vivir bien': la subversión epistémica”, en Alicia Girón (coord.), Del "vivir bien" al "buen vivir", Ciudad de México, Instituto de Investigaciones Económicas, UNAM.

Clavero, Bartolomé [1994], Derecho indígena y cultura constitucional en América, Ciudad de México, Siglo XXI. 
Collier, Jane [1999], "Liberalismos y racismo: dos caras de la misma moneda", en Dimensión Antropológica, INAH, 15, 11-26, enero-abril, recuperado de https://goo.gl/z7hTVE

Cranston, Maurice [1957], John Locke: A Biography, New York, Macmillan.

Cugoano, Ottobah [2013], Thoughts and sentiments on the evil and wicked traffic of the slavery: and commerce of the human species, humbly submitted to the inhabitants of Great-Britain. Cambridge University Press, $162 \mathrm{pp}$.

De Assis Clímaco, Danilo [2016], Ciencia en práctica. La emancipación desde las mujeres indígenas (tesis doctoral), Ciudad de México, Facultad de Filosofía y Letras, UnAM.

De la Garza, Enrique [2010], Hacia un concepto ampliado de trabajo. Del concepto clásico al no clásico, Barcelona, Anthropos/UAM.

[2001], "Problemas clásicos y actuales de la crisis del trabajo", en Enrique de la Garza y Julio César Neffa (comps.), El trabajo del futuro. El futuro del trabajo, Buenos Aires, Clacso/CEIL-PIETTE/CONICET-Trabajo y Sociedad.

Deutscher, Isaac [1963], Trotsky. El profeta desterrado, Ciudad de México, Era.

Diez, Fernando [2001], Utilidad, deseo y virtud. La formación de la idea moderna de trabajo, Barcelona, Ediciones Península.

_- [2014], Homo-Faber, Historia intelectual del trabajo, Madrid, Siglo XXI.

Duchet, Michele [1976], Antropología e Historia en el Siglo de las Luces, Ciudad de México, Siglo XXI.

Durán, José [2006], "La construcción social del concepto moderno de trabajo", en Nómadas. Revista Crítica de Ciencias Sociales y Jurídicas, Universidad Complutense 
de Madrid, 13, (1): enero-junio, recuperado de https:// www.redalyc.org/articulo.oa?id=18101317

Dussel, Enrique [2000], "Europa, modernidad y eurocentrismo", en Edgardo Lander (com.), La colonialidad del saber: eurocentrismo y ciencias sociales Perspectivas latinoamericanas, Buenos Aires, Clacso.

[1994], 1492. El encubrimiento del otro: hacia el origen del mito de la modernidad, La Paz, UMSA, Facultad de Humanidades y Ciencias de la Educación/ Plural Editores.

[1988], Hacia un Marx desconocido. Un comentario de los Manuscritos del 61-63, Ciudad de México, Siglo XXI.

Echevarría, Bolívar [2001], Definición de cultura, Ciudad de México, Facultad de Filosofía y Letras, UnAm.

Eliade, Mircea [1999], Historia de las creencias y las ideas religiosas. De Mahoma a la era de las Reformas, Buenos Aires, Paidós.

Esteva, Gustavo [20013], “Tiempos de indignación, tiempos de reflexión”, en Rebelarse desde el nosotrxs. Porque desde el abismo es imposible vivir sin luchar..., Querétaro, En cortito q's pa' largo.

EZLn [s/f], Gobierno Autónomo I. Cuaderno de texto de primer grado del curso de "La Libertad según l@s Zapatistas".

Farr, J. [2008], So vile and Miserable an Estate: The Problem of Slavery in Locke's Political Thought, Political Theory, Madison, University of Wisconsin, 14, (2): May.

Febvre, Lucien [1992], El problema de la incredulidad en el siglo XXI. La religión de Rabelais, Madrid, Ediciones Akal.

Federici, Silvia [2013], Revolución en punto cero. Trabajo doméstico, reproducción y luchas feministas, Madrid, Traficantes de sueños.

[2010], El Calibán y la Bruja, Madrid, Traficantes de Sueños. 
Fohlen, Claude y Bédarida [1965], Historia general del trabajo, Ciudad de México, Grijalbo.

Fontana, Josep [1982], Historia. Análisis del pasado y proyecto social, Barcelona, Crítica.

Foucault, Michel [2003], Vigilar y castigar. Nacimiento de la prisión, Ciudad de México. Siglo XXI.

Friedman, George [1992], "Introducción y metodología", en George Friedmann y Pierre Naville, Tratado de Sociología del Trabajo I, Ciudad de México, Fondo de Cultura Económica.

Galcerán, Montserrat [2016], La bárbara Europa. Una mirada desde el postcolonialismo y la descolonialidad, Madrid, Traficantes de Sueños.

Glausser, W. [1990], "Three Approaches to Locke and the Slave Trade", en Journal of the History of Ideas, 51 (2): 199-221, Apr.-Jun.

Garcés, Olga [2008], "El trabajo asalariado: La mecanización del espíritu”, en Revista Ad-minister (12), ene.-jun., 119-139.

Genovesi, Antonio [1786], Lecciones de Comercio o bien de Economía Civil, Madrid, Viuda de Ibarra, Hijos y Compañía.

Germaná, César [2011], "El pensamiento desde el Sur de los intelectuales críticos", en Julio Mejía Navarrete (ed.), América Latina en debate: sociedad, conocimiento e intelectualidad. II Foro Internacional y Encuentro de la Asociación Latinoamericana de Sociología, Lima, Universidad Ricardo Palma-Editorial Universitaria. [1995], El socialismo indo-americano de José Carlos Mariátegui: proyecto de reconstitución del sentido histórico de la sociedad peruana, Lima, Amauta.

Giglio, Julián [2014], “¿Genovesi: pensador de transición (es)?”, en Perspectivas. Revista de Análisis de Economía, Comercio y Negocios Internacionales (8): 71-90, agosto. Guamán Poma de Ayala, Felipe [1996], Nueva Crónica y Buen Gobierno, t. II, Caracas, Biblioteca Ayaucho. 
[1993], Nueva Corónica y Buen Gobierno, Ciudad de México, Fondo de Cultura Económica.

Gutiérrez Aguilar Raquel [2015] "A propósito del trabajo de Silvia Federici. Colocar la reproducción material y simbólica de la vida social y la capacidad humana de producir lo común como punto de partida para la reflexión crítica y la práctica política", en El Apantle. Revista de Estudios Comunitarios (1), octubre.

Hirschman, Albert O. [2014], Las pasiones y los intereses: argumentos políticos en favor del capitalismo previos a su triunfo, Madrid, Capitán Swing.

Hobsbawm, Eric [1998a], La era de la revolución, 17891848, Barcelona, Crítica.

- [1998b], Historia del Siglo XX, Barcelona, Crítica.

Hopenhayn, Martin [1988], El trabajo. Itinerario de un concepto, Santiago de Chile, PET-Cepaur.

Hund, D. Wulf [2014], "Racism in White Sociology. From Adam Smith to Max Weber", en Wulf, D. Hund y Alana Lentin (eds.), Racism and Sociology.

Ibáñez, Hilario [2002], De la integración a la exclusión. Los avatares del trabajo productivo a finales del siglo XX, Santander, Sal Terrae.

Innerarity, Carmen [1990], La comprensión aristotélica del trabajo, Anuario filosófico, 23, (2): 69-108, recuperado de https://goo.gl/mH9KsY

Jaccard, Pierre [1977], Historia social del trabajo. Desde la antigüedad hasta nuestros días, Barcelona, Plaza y Janés.

Jaeger, Werner Wilhelm [1962], Joaquín Xirau y Wenceslao Roces (trads.), Paideia. Los ideales de la cultura griega, Ciudad de México, Fondo de Cultura Económica. Kirkland, Justin Scott [2013], From Rite to Right: How Holy Days Became a Natural Right in Medieval England, a Thesis in History, Degree of Master of Arts, Faculty of Texas Tech University, recuperado de https://goo. $\mathrm{gl} / \mathrm{hzfHG} 7$ 
Lander, Edgardo [2008], Contribución a la crítica del marxismo realmente existente: verdad, ciencia y tecnología, Caracas, Fundación Editorial El perro y la rana.

[2006], "Marxismo, eurocentrismo y colonialismo", en Atilio A. Boron, Javier Amadeo y Sabrina González (comps.), La teoría marxista hoy. Problemas y perspectivas, Buenos Aires, Clacso.

[2000], "Ciencias sociales: saberes coloniales y eurocéntricos", en Edgardo Lander (comp.), La colonialidad del saber: eurocentrismo y ciencias sociales. Perspectivas latinoamericanas, Buenos Aires, Clacso.

Le Goff, Jacques [2003], “Trabajo”, en Jacques Le Goff y Jean-Claude Schmitt (eds.), Diccionario razonado del occidente medieval, Madrid, Akal.

_ [1983], Tiempo, trabajo y cultura en el occidente medieval, Madrid, Taurus.

__ [1969], La civilización del occidente medieval, Barcelona, Editorial Juventud.

Locke, John [s/f], Segundo tratado sobre el gobierno civil, recuperado dehttps://goo.gl/zcGgws

López, Dania [2014], "La reciprocidad como lazo social fundamental entre las personas y con la naturaleza en una propuesta de transformación societal", en Boris Marañón (coord.), Buen Viviry descolonialidad. Crítica al desarrollo y la racionalidad instrumentales, Ciudad de México, IIEc-unam/Clacso.

Lourenço, Francisco [1999] “A difusão das ideias económicas de Antònio Genovesi em Portugal”, en Cultura. Revista de História e Teoria das Ideias, (11): 553-576.

Lugones, María [2008], “Colonialidad y género", en Tabula Rasa (9): 73-101, julio-diciembre.

[2010], Hacia un feminismo descolonial, en Hypatia, 25, (4): otoño.

Manero, Ana [2009], "La controversia de Valladolid, España y el análisis de la legitimidad de la conquista de América", en Revista Electrónica Iberoamericana, 
Universidad Rey Juan Carlos, 3, (2); 85-114, julio-diciembre.

Marañón, Boris [2016a], "De la economía (social) y solidaria hacia la solidaridad económica, los Buenos Vivires y la Descolonialidad", en Revista Cooperativismo y Desarrollo (24).

[2016b], "Notas sobre la solidaridad económica y la descolonialidad del poder", en Boris Marañón (coord.), Políticas para la solidaridad económica y el Buen Vivir en México, Ciudad de México, IIEc-unam.

[2016c], “Notas sobre lo 'público' y lo 'privado' para la reproducción ampliada de la solidaridad económica y del Buen Vivir", en Boris Marañón (coord.), Políticas para la solidaridad económica y el Buen Vivir en México, Ciudad de México, IIEc-unam.

y Dania López [2016], "Del desarrollo capitalista al buen vivir, desde la descolonialidad del poder", en Intersticios, recuperado de https://goo.gl/ccahfW - [2014a], "La solidaridad económica en el Buen Vivir. Tendencias recientes (en América Latina y en Chiapas, México)", ponencia presentada en el Congreso ALASRU. Sociedades rurales latinoamericanas. Diversidades, contrastes y alternativas, Ciudad de México, 6-11 de octubre.

[2014b], "Crisis global y descolonialidad del poder. La emergencia de una racionalidad liberadora y solidaria”, en Boris Marañón (coord.), Buen Viviry descolonialidad. Crítica al desarrollo y la racionalidad instrumentales, Ciudad de México, IIEc-unam.

Marini, Ruy Mauro [ca. 1993], El concepto de trabajo productivo, recuperado de https://goo.gl/duTJz1

Marx, Carlos [1985], "Historia Crítica de la teoría de la plusvalía (I)", en Carlos Marx y Federico Engels, Obras Escogidas, t. 3, Ciudad de México, Ediciones Quinto Sol. 
Marx, Karl [1982], El capital, t. I, vol. I, libro primero, "El proceso de producción del capital", Ciudad de México, Siglo XXI.

[1982], El capital, t. I vol. II, libro primero, "El proceso de producción del capital”, Ciudad de México, Siglo XXI.

[1980], "Proyecto de respuesta a la carta a Vera Zálusich (1871)”, en Marx y Engels, Obras Escogidas, t. III, Moscú, Progreso, recuperado de https://goo.gl/ k1wnCd

[1976], Manuscritos económicos y filosóficos de 1844, Ciudad de México, Cultura Popular.

[s/f], Historia crítica de la teoría de la plusvalía (I), Obras escogidas, t. III, Ciudad de México.

Mandel, Ernest [1989], Tratado de Economía Marxista, t. 1, Ciudad de México, Era.

Mayo, Ariel [2013], Locke, la propiedad privada y el trabajo en los orígenes del liberalismo, recuperado de https://goo.gl/VsdRu9

Meda, Dominique [1996], "El valor trabajo visto en perspectiva", en Revista Internacional del trabajo, Ginebra, $115,(6)$.

[1998], El trabajo. Un valor en peligro de extinción, Madrid, Gedisa.

Merlo, Carlos [2013], "Aricó y una lectura crítica de la interpretación marxista eurocéntrica”, Revista Intersticios: Filosofía Latinoamericana, Filosofía Política, Historiografía. Sujetos politicos, saberes, prácticas y democracias en América Latina, 2, (4).

Medina, Javier [2001], "Sumaq Qamaña. La comprensión indígena de la buena vida", La Paz, Federación de Asociaciones Municipales de Bolivia: GTZ, Proyecto de Apoyo a la Gestión Participativa Municipal.

Mignolo, Walter [2007], "El pensamiento descolonial: desprendimiento y apertura. Un manifiesto", en Santiago Castro-Gómez y Ramón Grosfoguel (eds.), El giro 
decolonial. Reflexiones para una diversidad epistémica más allá del capitalismo global, Pontificia Universidad Javeriana/Instituto Pensar, Universidad central-IIESCO, Bogotá, Siglo del Hombre Editores.

Mills, C. Wright [s/f], The Meanings of Work Throughout History, recuperado de https://goo.gl/79whmY

Mondolfo, Rodolfo [1959], Problemas de cultura y de educación, Buenos Aires, Librería Hachette.

Mossé, Claude [1969], The Ancient World at Work, Nueva York, Norton.

Murra, John V. [1978], Formaciones económicas y políticas andinas, Lima, IEP.

Naredo, José M. [1997], “Configuración y crisis del mito del trabajo”, en VV. AA., ¿Qué crisis?: Retos y transformaciones de la sociedad del trabajo, Donostia, Prentsa. - [1987], La economía en evolución. Historia y perspectivas de las categorías básicas de la ciencia económica, Madrid, Siglo XXI.

Neffa, Julio César [2001], "Presentación sobre el debate reciente sobre el fin del trabajo", en Enrique de la Garza y Julio César Neffa (comps.) El trabajo del futuro. El futuro del trabajo, Buenos Aires, Clacso/CEIL-PIETTE/ Conicet-Trabajo y sociedad.

- [1999], “Actividad, trabajo y empleo: algunas reflexiones sobre un tema en debate", en Orientación y Sociedad, vol.1, La Plata, enero-diciembre.

Noguera, Antonio [2002], El concepto de trabajo y la teoría social crítica, en Papers (68): 141-168.

Ovitt, George [1987], The Restoration of Perfection: Labor and Technology in Medieval Culture, New Brunswick, Rutgers University Press.

- [1986], "The Cultural Context of Western Technology: Early Christian Attitudes toward Manual Labor", en Technology and Culture, 27 (3): 477-500.

Palmade, Guy [1976], Historia Universal Siglo XXI. La época de la burguesía, Ciudad de México, Siglo XXI. 
Peig, Concepción [2007], Génesis del concepto de trabajo en Santo Tomás. Su contexto histórico y doctrinal (tesis doctoral [extracto]), Universidad de Navarra, pp. 50, 51-143, recuperado de https://goo.gl/mRprUp

Quijano, Aníbal [2014], "El trabajo al final del siglo xx," en Aníbal Quijano, Cuestiones y horizontes: de la dependencia histórico-estructural a la colonialidad/descolonialidad del poder, Buenos Aires, Clacso.

[2013], "El moderno Estado-Nación en América Latina: cuestiones pendientes", texto presentado en el "IV Encontro da Cátedra América Latina e Colonialidade do Poder. Para além da crise? Horizontes desde uma perspectiva decolonial”, Río de Janeiro.

_ [2011], “Bien Vivir'. Entre el 'desarrollo' y la Des/ Colonialidad del Poder", en Revista Ecuador Debate (8): 77-87, diciembre.

- [2009], "Otro horizonte de sentido histórico", recuperado de https://goo.gl/2wdMUK

[2007a], Colonialidad del poder y clasificación social, en Santiago Castro-Gómez y Ramón Grosfoguel (eds.), El giro decolonial. Reflexiones para una diversidad epistémica más allá del capitalismo global, Bogotá, Pontificia Universidad Javeriana/Instituto Pesar, Universidad central-IIEsco, Siglo del Hombre Editores.

- [2007b], “'Sistemas alternativos de producción?”, en José Luis Coraggio, La economía social desde la periferia, Buenos Aires, Contribuciones latinoamericanas, Universidad Nacional de General Sarmiento-Altamira. - [2000], "Colonialidad del poder, eurocentrismo y América Latina", en Edgardo Lander (comp.), La colonialidad del saber: eurocentrismo y ciencias sociales Perspectivas latinoamericanas, Buenos Aires, Clacso. [1998], "Un fantasma recorre el mundo", Revista Estudios Avanzados, 12 (34). 
- [1990], "Notas sobre los problemas de la investigación social en América Latina”, en Revista de Sociología 6, (7).

[1988], Modernidad, Identidad y Utopía en América Latina, recuperado de https://goo.gl/pBxzUG

Ramella, Susana [2011], "La concepción antropológica del derecho del trabajo en el constitucionalismo social del siglo xx", en Revista Historia del Derecho (42): julio-diciembre.

Rifkin, Jeremy [1996], El fin del trabajo. Nuevas tecnologías contra puestos de trabajo: el nacimiento de una nueva era, Ciudad de México, Paidós.

Rodríguez Zoya, L. [2009], "Propiedad y esclavitud en el pensamiento económico de Aristóteles: génesis del bios económico", en Revista Científica de UCES, 13, (1): 67-91.

Roll, Eric [1974], Historia de las doctrinas económicas, Ciudad de México, Fondo de Cultura Económica

Romero, Agustín [2001], "Opus manuum, trabajo intelectual y nuevas tecnologías”, ponencia presentada en la XXVIII Semana de Estudios Monásticos, Loyola, recuperado de https://goo.gl/HQkG3o

Rosales, Amán [2005], "Ilustración y progreso en David Hume”, en LOGOS. Anales del Seminario de Metafísica (38): 117-141.

Ryken, Leland [2002], Work and Leisure in Christian Perspective, Oregon, Wipf and Stock Publishers.

Sabine, George [2012], Historia de la teoría política, Ciudad de México, Fondo de Cultura Económica.

Saboul, Albert [s/f], Compendio de historia de la Revolución francesa, recuperado de https://goo.gl/MBWHKU

San Agustín [s/f], La Ciudad de Dios, recuperado de https:// goo.gl/kQNERM

Santo Tomás de Aquino [s/f], Del gobierno de los príncipes, recuperado de https://goo.gl/HcgB8G 
Salcedo, Juan [1987], "La conciencia sociológica en la Ilustración escocesa", en Anales de Estudios Económicos y Empresariales 2: 147-167.

Segato, Rita [2015], La crítica de la colonialidad en ocho ensayos y una antropología por demanda, Buenos Aires, Prometeo.

Sennett, Richard [2000], La corrosión del carácter. Las consecuencias personales del trabajo en el nuevo capitalismo, Barcelona, Anagrama.

Sepúlveda, Juan Ginés de [s/f], Demócrates segundo o De las justas causas de la guerra contra los indios, recuperado de https://goo.gl/SBtnAi

Severo, Joan [2013], “Apropiación privada de la tierra y derechos políticos en la obra de John Locke, Ingenium", en Revista de historia del pensamiento moderno (7): 193-210.

__ [2013] "Un análisis de las nociones de abundancia y esclavitud para reinterpretar el carácter universal de la teoría de la apropiación de John Locke", en Las Torres de Lucca (2): 69-93, enero-junio.

Shalins, Marshall [1975], Economía de la Edad de Piedra, Madrid, Akal.

Shanin, Teodor [1990], El Marx tardío y la vía rusa. Marx y la periferia del capitalismo, Madrid, Revolución.

Silva Herzog, Jesús [1961], Historia del pensamiento económico-social: de la antigüedad al siglo XVI, Ciudad de México Fondo de Cultura Económica.

Simón, Ives, [1987], Trabajo, Sociedad y cultura, Caracas, Ifedec.

Smith, Adam [2014], Investigación sobre la naturaleza y causas de la riqueza de las naciones, México, Fondo de Cultura Económica.

Soboul, Albert [1985], La revolución francesa, Barcelona, Orbis.

Squadrito, Kathy [2002-2007], "Locke and the Dispossession of the American Indian", en Julie K. Ward y 
Tommy L. Lott (eds.), Philosophers on Race: Critical Essays, Oxford, Blackwell Publishers Ltd.

Tilgher, Adriano [1930], Work: What It Has Meant to Men through the Ages, Nueva York, Harcourt, Brace and Company.

Thompson, Edward P. [1984], “Tiempo, disciplina de trabajo y capitalismo industria”, en Tradición, revuelta y consciencia de clase: Estudio sobre la crisis de la sociedad preindustrial, Madrid, Grijalbo.

Theocarakis, Nicholas [2010], "Metamorphoses: The Concept of Labour in the History of Political Economy", en The Economic and Labour Relations Review 20, (2): 7-38, septiembre.

Tomich, Dale [2011], Pelo Prisma da Escravidao. Trabalho, Capital e Economía Mundial, Universidad de Sao Paolo, Sao Paulo.

Troeltsch, Ernst [1981], The social Teaching of the Christian Churches, Chicago, University of Chicago Press.

Trotsky, León [ 2000], La revolución traicionada, Ciudad de México, Era.

Udi, Stanley [1971], El trabajo en las sociedades tradicional y moderna, Buenos Aires, Amorrortu Editores.

Ulas-Ince, Onur [2012], Colonial Capitalism and the Dilemmas of Liberalism: Locke, Burke, Wakefield and the British Empire, recuperado de https://goo.gl/R12bH7 Uzgalis, William [2002-2007], "An Inconsistency not to be Excused: On Locke and Racism”, en Julie Ward y Tommy Lott (eds.), Philosophers on Race: Critical Essays, Oxford, Blackwell Publishers Ltd,.

Valenzuela Feijóo [1977], "Adam Smith y la idea del trabajo productive e improductivo", en Problemas del Desarrollo 9 (28), año viI.

Van Kessel, Juan y Dionisio Condori [1992], Criar la vida. Trabajo y tecnología en el mundo andino, Santiago de Chile, Vivarium. 
Várnagy, Tomás [1999], El pensamiento politico de Martín Lutero, en La filosofía política clásica. De la Antigüedad al Renacimiento, Buenos Aires, Clacso.

Wallerstein, Inmanuel [2011], El moderno sistema mundial. La agricultura capitalista y los orígenes de la economía-mundo europea en el siglo XVI, vol. I, Ciudad de México, Siglo XXI.

__ [2007], Universalismo europeo, El discurso del poder, Ciudad de México, Siglo XXI.

_ y Etienne Balibar [1991], Raza, nación y clase, Madrid, Iepala Editorial.

- [1988], El capitalismo histórico, Ciudad de México, Siglo XXI.

Weber, Max [1984], La ética protestante y el desarrollo del capitalismo, Ciudad de México, Colofón.

Williams, Eric [1975], Capitalismo y esclavitud, La Habana, Editorial de Ciencias Sociales.

Wolf, Eric [2014], "Europa y la gente sin historia, México", en María del Carmen Zabala Argüelles (comp.), Pobreza, exclusión social y discriminación étnico-racial en América Latina y el Caribe, Bogotá, Clacso/Siglo del Hombre Editores.

Zavala, Silvio [1968], Los títulos de posesión a las indias occidentales (curso impartido en El Colegio Nacional), recuperado de http://es.scribd.com.

Zemelman, Hugo y Guadalupe Valencia [1990], "Los sujetos sociales, una propuesta de análisis", en Acta sociológica 3, (2), Facultad de Ciencias Políticas y Sociales, UNAM.

Zibechi, Raúl [2015] "Los trabajos colectivos como bienes comunes material/simbólicos”, en El Apantle. Revista de estudios comunitarios (1): Octubre. 
Una crítica descolonial del trabajo, es una obra del Instituto de Investigaciones

Económicas de la unam. Se terminó de imprimir en noviembre de 2017. Se tiraron 250 ejemplares en offset en los talleres de Dat@Color Impresores,

S.A. de C.V., Avena 201, Granjas México, deleg. Iztacalco, C.P. 08400, CDMX.

Para su composición se utilizaron tipos New Aster

y Univers Condensed de 11, 10, 9, 8.5 y 8 pts., sobre papel bond ahuesado de $90 \mathrm{~g}$;

los forros son de cartulina couché mate de $300 \mathrm{~g}$.

El cuidado de la edición estuvo a cargo de Marisol Simón. 